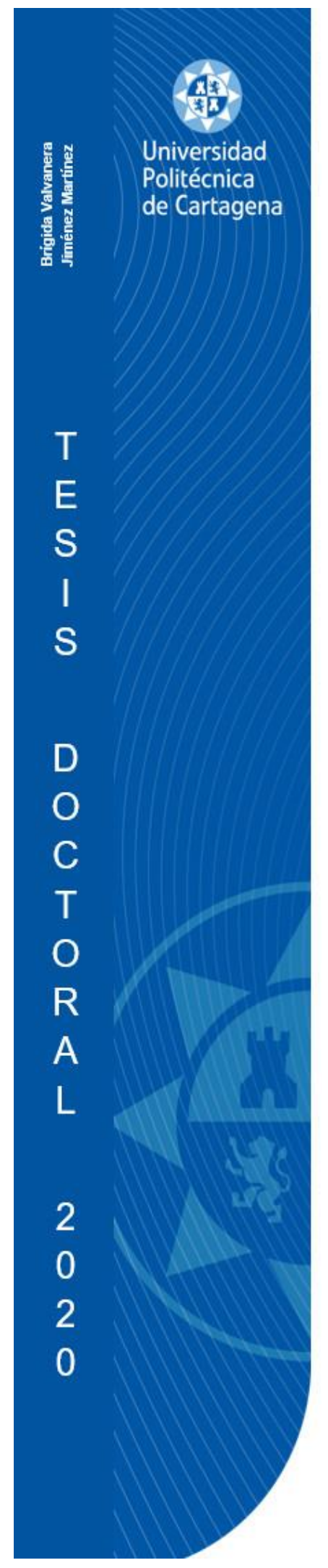

\title{
\begin{tabular}{l|l} 
Universidad & Campus
\end{tabular}
}

Politécnica de Excelencia

de Cartagena Internacional

\section{LA RESPONSABILIDAD DEL ADMINISTRADOR DE HECHO}

Programa de Doctorado: Ciencias

Económicas, Empresariales y Jurídicas

Autora: Brígida Valvanera Jiménez

Martínez

Directora: María del Mar Andreu Martí

Cartagena 2020 


\section{LA RESPONSABILIDAD DEL ADMINISTRADOR DE HECHO}

Autora: Brígida Valvanera Jiménez Martínez

Directora de la Tesis: Dra. María del Mar Andreu Martí

Departamento: Métodos Cuantitativos, Ciencias Juridicas y Lenguas Modernas

Facultad de Ciencias de la Empresa 


\section{Universidad}

Politécnica

de Cartagena

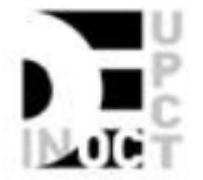

DT-16

\section{CONFORMIDAD DE SOLICITUD DEAUTORIZACIÓN DE DEPÓSITO DE}

\section{TESIS DOCTORAL POR EL/LA DIRECTOR/A DE LA TESIS}

Da. María del Mar Andreu Martí, Directora de la Tesis doctoral "La Responsabilidad del Administrador de hecho"

\section{INFORMA:}

Que la referida Tesis Doctoral, ha sido realizada por $\mathrm{D}^{a}$. Brigida Valvanera Jiménez Martinez, dentro del Programa de Doctorado Ciencias Económicas, Empresariales y Juridicas, dando mi conformidad para que sea presentada ante el Comité de Dirección de la Escuela Internacional de Doctorado para ser autorizado su depósito.

Informe positivo sobre el plan de investigación y documento de actividades del doctorando/a emitido por el Director/ Tutor (RAPI).

La rama de conocimiento en la que esta tesis ha sido desarrollada es:

Ciencias Sociales y Juridicas

En Cartagena, a 15 de Septiembre de 2020

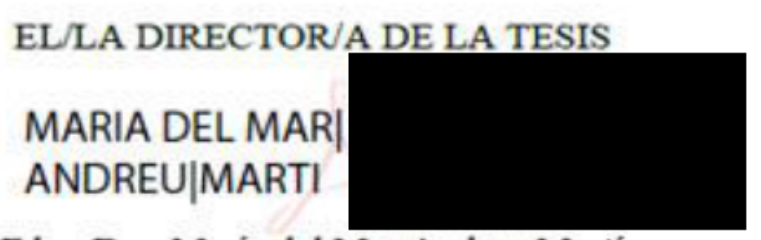

Fdo.: Dra. María del Mar Andreu Martí 


\section{Universidad}

Politécnica

de Cartagena

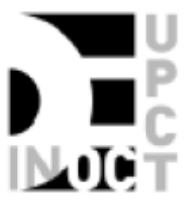

DT-17

\section{CONFORMIDAD DE DEPÓSITO DE TESIS DOCTORAL POR LA COMISIÓN ACADÉMICA DEL PROGRAMA}

D. Carmelo Reverte Maya, Presidente de la Comisión Académica del Programa Ciencias Económicas, Empresariales y Jurídicas.

\section{INFORMA:}

Que la Tesis Doctoral titulada, "La Responsabilidad del Administrador de hecho", ha sido realizada, dentro del mencionado Programa de Doctorado, por $\mathrm{D}^{\mathrm{a}}$. Brígida Valvanera Jiménez Martínez, bajo la dirección y supervisión de la Dra. María del Mar Andreu Martí.

En reunión de la Comisión Académica, visto que en la misma se acreditan los indicios de calidad correspondientes y la autorización del Director/a de la misma, se acordó dar la conformidad, con la finalidad de que sea autorizado su depósito por el Comité de Dirección de la Escuela Internacional de Doctorado.

$\mathrm{X}$ Evaluación positiva del plan de investigación y documento de actividades por el Presidente de la Comisión Académica del programa (RAPI).

La Rama de conocimiento por la que esta tesis ha sido desarrollada es:

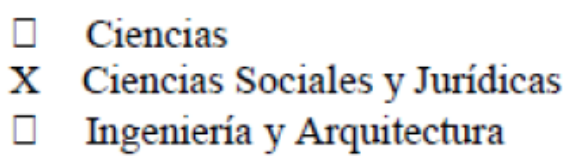

En Cartagena, a 15 de septiembre de 2020

\section{EL PRESIDENTE DE LA COMISIÓN ACADÉMICA}

CARMELO| REVERTE|MAYA

Fdo: Dr. Carmelo Reverte Maya. 


\section{RESUMEN}

La Ley $31 / 2014$, de 3 de diciembre, para la mejora del gobierno corporativo de las sociedades de capital amplió la responsabilidad de los administradores a aquellas personas que, sin haber sido formalmente nombradas administradores, realizaran las funciones propias de un administrador societario. Así, en el art. 236.3 Ley de Sociedades de Capital define al administrador de hecho como aquella persona que ejerce las funciones propias de administrador en el tráfico mercantil con un título nulo, extinguido o caducado, e incluso sin ningún título, o con cualquier otro título. Al tiempo, considero también administrador de hecho a aquella persona que ocultamente actuaba como administrador dando instrucciones a los administradores nombrados por la sociedad, es decir, el administrador de hecho oculto. No obstante, nuestro legislador se limita a describirle funcionalmente sin describirle desde un punto de vista formal dejando muchas cuestiones sin resolver.

El objetivo de este estudio es determinar la responsabilidad del administrador de hecho en nuestras sociedades de capital, en relación con el concepto legal del administrador de hecho establecido por la Ley 31/2014. Con este fin las preguntas de investigación son las siguientes: La primera, delimitar claramente quién puede ser administrador de hecho y la segunda, quién administrador oculto. En este contexto, encajamos el concepto de administrador de hecho dentro de sus manifestaciones y concretamente, al administrador oculto. La dificil identificación del administrador de hecho oculto la encontraremos por el hecho notorio de que este tipo de administrador esconde su actuación en la realidad del tráfico, a través, de dos formas. La primera, cuando actúa externamente porque lo hace bajo la apariencia de cualquier titulo societario o incluso sin ningún título y, la segunda, cuando actúa en el ámbito interno dando instrucciones a los administradores societarios en la sombra.

Las preguntas de investigación se responden a través del estudio de esta figura, desde un enfoque doctrinal y jurisprudencial realizando un análisis exhaustivo de todos los tipos de administrador de hecho para poder identificar a esta figura, con base en el perfil funcional, tal y como viene establecido en el art. 236.3 LSC. En definitiva, trataremos de concretar cuándo podemos exigir la responsabilidad a los 
administradores de hecho cuando administran la sociedad bajo la apariencia de otros cargos societarios u otras figuras para que cualquier persona no se convierta en administrador de hecho por el hecho de realizar funciones que corresponden a los administradores. 


\section{Agradecimientos}

A mi familia por su tiempo y generosidad. A mi directora de tesis por su dedicación, apoyo y empeño en todo momento para que esta tesis llegara, por fin, a ver la luz. 


\section{ÍNDICE}

ABREVIATURAS

\section{CAPÍTULO PRIMERO}

\section{LA CONFIGURACIÓN DEL ADMINISTRADOR DE HECHO EN LAS SOCIEDADES DE CAPITAL}

\section{INTRODUCCIÓN}

II. ANTECEDENTES DEL ADMINISTRADOR DE HECHO 26

1. Evolución del concepto de administrador de hecho 26

2. Aproximación a los orígenes del administrador de hecho en el derecho comparado 33

3. El concepto del administrador de hecho antes de la reforma de la Ley 31/2014 37

4. Hacia la configuración del perfil funcional del administrador de hecho 42

\section{LA EQUIPARACIÓN AUTOMÁTICA DEL ADMINISTRADOR DE} HECHO COMO ADMINISTRADOR SOCIETARIO A LA LUZ DE SU DEFINICIÓN LEGAL

1. Delimitación previa

2. La problemática que plantea la definición legal del administrador de hecho 54

3. Las manifestaciones de los distintos tipos que la Ley define como administradores de hecho $\quad 57$

3.1. Administrador de hecho notorio 57

3.2. Administrador de hecho oculto bajo cualquier título 59

3.3. Administrador de hecho oculto propiamente dicho 59

4. Criterios identificativos del perfil funcional de los administradores de hecho 61

4.1. Planteamiento $\quad 61$ 
4.2 Criterios de identificación de la actuación de un administrador de hecho

4.2.1. Actividad positiva de gestión o administración

4.2.2. Actuación permanente de dirección de la sociedad 66

4.2.3. Ejercicio de las funciones con total independencia 68

4.2.4. Conocimiento y consentimiento de la sociedad

\section{EL ADMINISTRADOR OCULTO Y SU ESPECIAL CONSIDERACIÓN} COMO ADMINISTRADOR DE HECHO

1. Antecedentes

2. El administrador oculto: un tipo legal de administrador de hecho

2.1. Delimitación previa 76

2.2. Concepto de administrador de hecho oculto

3. Perfiles de administrador de hecho oculto: supuestos controvertidos generalmente excluidos

\section{LAS MANIFESTACIONES CONCRETAS DEL ADMINISTRADOR DE} HECHO

1. El administrador de hecho notorio

2. El administrador de hecho oculto bajo otra apariencia 86

2.1. El representante aparente $\quad 86$

2.2. La persona física representante de la persona jurídica administradora 90

2.3. Altos cargos con amplias facultades de dirección 92

2.3.1. El director general

2.3.1.1. El alcance de las facultades indelegables en el $\begin{array}{ll}\text { administrador de hecho } & 97\end{array}$

$\begin{array}{ll}\text { 2.3.2. El apoderado general } & 100\end{array}$

3. El administrador oculto en sentido estricto 104

$\begin{array}{ll}\text { 3.1. Los accionistas mayoritarios } & 104\end{array}$

3.2. Los acreedores y prestadores de servicios y otras figuras afines bajo la $\begin{array}{ll}\text { cobertura de un contrato societario } & 107\end{array}$

3.3. El administrador de hecho y su alcance en los grupos de sociedades 110 
1. Necesidad de prueba del administrador de hecho

2. Indicios generales de identificación del administrador de hecho

\section{CAPÍTULO SEGUNDO}

\section{LA APLICACIÓN DE LOS DEBERES DE LOS ADMINISTRADORES AL ADMINISTRADOR DE HECHO}

\section{DELIMITACIÓN PREVIA}

1. El deber de diligencia

1.1. El deber de diligencia como cláusula abstracta y su cumplimiento por el administrador de hecho en función de los tipos de sociedades y de los modelos de organización

1.2. La concreción del deber de diligencia con la Business Judgment Rule

1.2.1. El origen de la Business Judgment Rule

1.2.2. Objetivo y requisitos de la protección de la discrecionalidad empresarial Business Judgment Rule

1.2.3. Ámbito de aplicación

1.3. Los deberes específicos del deber de diligencia

1.3.1. El deber y derecho de información

2. El deber de lealtad

2.1. El concepto del deber de lealtad

2.2. Las conductas del deber de lealtad. Su concreción 


\section{CAPÍTULO TERCERO}

\section{LA RESPONSABILIDAD DEL ADMINISTRADOR DE HECHO}

\section{GENERALIDADES}

\section{LA EXTENSIÓN SUBJETIVA DE LA RESPONSABILIDAD DE LOS} ADMINISTRADORES AL ADMINISTRADOR DE HECHO

1. La evolución de la exigencia de la responsabilidad al administrador de hecho

2. Los presupuestos materiales de la responsabilidad de los administradores en

el de hecho

2.1. Delimitación previa

2.2. Los requisitos de la responsabilidad general de los administradores en el administrador de hecho

2.3. La diligencia como medida de la culpa para exigir la responsabilidad y la presunción de culpabilidad

2.4. La presunción de culpabilidad del administrador de hecho en los actos realizados en contra de la Ley o los estatutos

\section{LA PROBLEMÁTICA DE LA RESPONSABILIDAD SOLIDARIA EN EL}

\section{ADMINISTRADOR DE HECHO}

1. En general

2. La responsabilidad solidaria entre el administrador de hecho y el administrador de derecho

\section{EL RÉGIMEN ESPECIAL DE RESPONSABILIDAD POR}

\section{OBLIGACIONES SOCIALES EN EL ADMINISTRADOR DE HECHO}

1. Evolución del ámbito objetivo y subjetivo

2. Presupuestos de la responsabilidad por obligaciones sociales

2.3. La presunción de las deudas posteriores a la causa de disolución

3. Extensión de la responsabilidad por obligaciones sociales al administrador de hecho 
3.2. La extensión por obligaciones sociales al administrador de hecho

4. Coordinación entre la responsabilidad societaria y la concursal

\section{APROXIMACIÓN A LA RESPONSABILIDAD DEL ADMINISTRADOR} DE HECHO EN EL ÁMBITO CONCURSAL

1. Planteamiento

2. La responsabilidad concursal. Su especial regulación

2.1. Actuaciones u omisiones desencadenantes de la responsabilidad concursal general y su aplicación al administrador de hecho

2.2. La naturaleza de la responsabilidad por déficit patrimonial

2.3. La responsabilidad del administrador de hecho por déficit patrimonial. Sus presupuestos 
PRELIMINAR 
El objeto de la presente Tesis Doctoral es el estudio de la responsabilidad del administrador de hecho en nuestras sociedades de capital en relación con el concepto legal de administrador de hecho establecido por la Ley 31/2014, de 3 de diciembre, para la mejora del gobierno corporativo de las sociedades de capital.

De ahí que pretendamos conseguir dos objetivos. El primero, delimitar quién es el administrador de hecho en la sociedad y, el segundo, cuándo el administrador de hecho incumple sus deberes como administrador con el fin de poder exigirle responsabilidad y resarcir a la sociedad, a los accionistas y a los acreedores societarios de los daños derivados de su actuación. A tal efecto, tendremos que estudiar los deberes fiduciarios de los administradores y los presupuestos generales del régimen jurídico de la responsabilidad. Con carácter previo, deviene necesario estudiar el origen y desarrollo del concepto del administrador de hecho en el primer capítulo de este trabajo. Para tal fin, se abordará la evolución de su concepto, que se inicia carente de regulación y que se va gestando gracias a la doctrina y la jurisprudencia. No es hasta la reforma de la Ley 26/2003, de 17 de julio (en adelante, Ley de Transparencia) cuando se reconoció este concepto en la legislación societaria.

La Ley de Transparencia, influenciada por el Informe Aldama de 8 de enero de 2003, elevó al plano normativo aquella recomendación que aconsejaba la extensión de todos los deberes de lealtad a las personas que desempeñaban una posición similar a la de los administradores, y exigió al administrador de hecho el cumplimiento de todos sus deberes. Sin embargo, el concepto legal de administrador de hecho no se llegó a establecer hasta que se promulgó la Ley 31/2014, por la que se modifica la Ley de Sociedades de Capital, para la mejora del gobierno corporativo.

Por este motivo debemos de estudiar el origen y fundamento de la Ley 31/2014, que fue la que determinó la definición del administrador de hecho en el art. 236.3 de la Ley de Sociedades de Capital y que, además, modificó los deberes de los administradores y su responsabilidad en el Texto Refundido de dicha Ley (en adelante, LSC), aprobado por el Real Decreto Legislativo 1/2010, de 1 de julio.

Así pues, las medidas que fueron introducidas por la Ley 31/2014 en la LSC serán objeto de estudio en el segundo y tercer capítulo de este trabajo. Con las medidas adoptadas 
por esta Ley se modificaron las formas de organización de nuestras sociedades, sobre todo, de las sociedades cotizadas y, además, se introdujeron medidas muy significativas en materia de deberes consiguiendo que se estableciera un régimen más severo para la responsabilidad de los administradores.

En concreto, en el segundo capítulo esbozaremos los deberes y facultades de los administradores, en especial, el deber de diligencia que, tras la reforma operada por la Ley 31/2014, experimentó modificaciones importantes en el art. 225 LSC en torno a su modulación, atendiendo a la naturaleza del cargo y a las funciones atribuidas a cada uno de los administradores. Abordaremos, especialmente, el deber de lealtad establecido en el art. 227 LSC, donde la referencia al interés general va más allá del interés de los socios, pues, tras la Ley 31/2014, el interés de la sociedad se entenderá de modo muy amplio (socios, empleados, clientes, proveedores).

En relación con nuestro objeto de estudio, la Ley 31/2014 amplió la responsabilidad de los administradores a aquellas personas que, sin haber sido formalmente nombradas como administradores, realizan las funciones propias de un administrador societario. Así, en el art. 236.3 LSC se define al administrador de hecho como aquella persona que ejerce las funciones propias de administrador en el tráfico mercantil con un título nulo, extinguido o caducado e, incluso, sin ningún título o con cualquier otro título. Al tiempo, consideró también administrador de hecho a aquella persona que ocultamente actuaba como administrador dando instrucciones a los administradores nombrados por la sociedad, es decir, el administrador oculto. No obstante, nuestro legislador se limita a describirle funcionalmente dejando muchas cuestiones y lagunas sin resolver, que asimismo abordaremos.

En definitiva, nos centraremos en dar respuesta a dos cuestiones. La primera, delimitar claramente quién puede ser administrador de hecho y, la segunda, quién es el administrador oculto.

La pretensión de este trabajo es, consiguientemente, el de encajar el concepto de administrador de hecho dentro de sus manifestaciones y, muy concretamente, el de administrador oculto. La difícil identificación del administrador oculto la encontraremos por el hecho notorio de que este tipo de administrador se esconde con su actuación en la realidad del tráfico, básicamente a través de dos formas. La primera, cuando actúa externamente, 
porque lo hace bajo la apariencia de cualquier título societario o, incluso, sin ningún título y, la segunda, cuando actúa en el ámbito interno dando instrucciones a los administradores societarios en la sombra. Por esta razón, profundizaremos en la figura del administrador oculto, de difícil identificación, recurriendo a la experiencia jurisprudencial.

Para entrar a fondo en el problema real de quién es el administrador de hecho delimitaremos los cargos de los apoderados, gerentes, representantes voluntarios, entre otros, y concretaremos cuándo un verdadero administrador de hecho se esconde detrás de un administrador societario bajo la apariencia de un simple apoderado o factor. También abordaremos la figura del administrador de hecho en la institución de los grupos de sociedades para averiguar la posible consideración de administrador de hecho de la sociedad dominante cuando esta imparte órdenes a los administradores de las sociedades dominadas.

En consecuencia, trataremos de concretar cuándo podemos exigir responsabilidad a los administradores de hecho desde el momento en que administran la sociedad bajo la apariencia de otros cargos, analizando esta posición en figuras tales como la del socio mayoritario y la del socio único de una sociedad unipersonal.

Para acometer esta labor caminaremos por un terreno pantanoso, lleno de lagunas, por la complejidad que engendra la propia figura del administrador de hecho, y nos encontraremos con preceptos oscuros susceptibles de diversas interpretaciones.

No obstante, el objetivo de este trabajo lo conseguiremos con el estudio de esta figura desde un enfoque doctrinal y jurisprudencial, realizando un análisis exhaustivo de todos los tipos de administradores de hecho para así poder identificar esta figura con base en el perfil funcional, tal y como viene establecido en el art. 236.3 LSC.

Culminaremos el objetivo de este trabajo estudiando la figura del representante del administrador como persona jurídica que, por su falta de regulación legal estricta, tal y como venía insistiendo nuestra doctrina, desencadena en la práctica importantes riesgos y problemas, hasta que la Ley 31/2014 recogió expresamente en el art. 236.5 LSC que la persona designada por la persona jurídica administradora para que realizara el ejercicio permanente de las funciones del cargo de administrador respondería por el incumplimiento de todos los deberes de los administradores. 
Tras esta compleja tarea, nos centraremos en la exigencia de responsabilidad al administrador de hecho en el capítulo tercero. A tal efecto, analizaremos la responsabilidad personal por obligaciones sociales, según indica el art. 367 LSC, haciendo especial referencia al régimen de la responsabilidad concursal de los administradores.

También abordaremos las vías principales de exoneración de la responsabilidad. En particular, analizaremos la exoneración mediante la regla del juicio empresarial, la "Business Judgment Rule", que supuso toda una novedad introducida por la Ley 31/2014, ya que, por primera vez, se estableció la presunción del buen hacer de los administradores en la toma de las decisiones empresariales de riesgo en el ordenamiento societario, concretando el deber de diligencia en el art. 226 LSC, y como una de las vías principales de exoneración de la responsabilidad societaria de los administradores.

Por último, nos aproximaremos al estudio de responsabilidad de los administradores de hecho en el ámbito concursal, apuntando algunas especialidades que inciden en el tema objeto de esta tesis, pero en las que no podemos entrar de forma más exhaustiva porque excedería del objeto de este trabajo. 


\section{ABREVIATURAS}


AAMN

AAMN

AC

ACM

AAVV

ADC

ADConc

art/arts

AktG

ALI

AJA

AJC

AP

APCM

BOE

BORME

CBG

CDC

CCJC

CUBG

CC

CCom.

CodcivI

Coord

CE

CEE

CEO

CNMV

Cit

CMS

CP

DA

Decr
Anales de la Academia Matritense y del Notariado

American Bar Association

Actualidad Civil

Anteproyecto de Código Mercantil

Varios Autores

Anuario de Derecho Civil

Anuario de Derecho Concursal

Artículo/ artículos

Aktiengesetz de 1965

American Law Institute

Actualidad Jurídica Aranzadi

Actualidad Jurídica de Cataluña

Audiencia Provincial

Anteproyecto de Código Mercantil

Boletín Oficial del Estado

Boletín Oficial del Registro Mercantil

Código de Buen Gobierno

Cuadernos de Derecho y Comercio

Cuadernos Cívitas de Jurisprudencial Civil

Código Unificado de Buen Gobierno

Código Civil

Código de Comercio

Código Civil Italiano

Coordinador

Constitución Española

Comunidad Económica Europea

Chief Executive Officer

Comisión Nacional del Mercado de Valores

Citado/citada

Concursal Mercantil Sociedades

Código Penal

Disposición Adicional

Decreto 


$\begin{array}{ll}\text { DGRN } & \text { Dirección General de Registros y Notariado } \\ \text { DN } & \text { Derecho de Negocios } \\ \text { Dir } & \text { Director } \\ \text { DT } & \text { Disposición Transitoria } \\ \text { Ed } & \text { Edición } \\ \text { EJB } & \text { Enciclopedia Jurídica Básica } \\ \text { Id } & \text { Idem } \\ \text { JUR } & \text { Jurisprudencia Aranzadi Westlaw }\end{array}$

LAIE

Ley de Agrupaciones de Interés Económico

LC

Ley Concursal

LCoop

Ley de Cooperativas

LEC

Ley de Enjuiciamiento Civil

LGC

Ley para la Mejora del Gobierno Corporativo

LGT

Ley General Tributaria

LMV

Ley del Mercado de Valores

LO

Ley Orgánica

LOPJ

Ley Orgánica del Poder Judicial

LRJSGR

Ley de Régimen Jurídico de Sociedades de Garantía

Recíproca

LME

Ley de Modificación Estructural

LSA

Ley de Sociedades Anónimas

LSCOP

Ley de Sociedades de Cooperativas

LSC

Ley de Sociedades de Capital

LSRL

Ley de Sociedades de Responsabilidad Limitada

LSL

Ley de Sociedades Laborales

NIC

Normas Internacionales de Contabilidad

Núm

Número

OECD

Organización para la Cooperación y Desarrollo Económico

OPA

Oferta Pública de Adquisición

PCM

Proyecto de Código Mercantil

RDBB

Revista de Derecho Bancario Bursátil

RD

Real Decreto

RDL

Real Decreto Legislativo 
RDGRN

RDM

RDP

RdS

RDI

Regl.

RCDI

RDCP

RGD

RJ

RCJ

RM

RPE

RPD

RRM

RJC

RSC

RSE

STC

STS

SA

SAP/SSAP

SAE

SRL

$\mathbf{T} / \mathbf{t}$

TCE

TS

$\mathbf{v}$

v. gr
Resolución de la Dirección General de los Registros y del

Notariado

Revista de Derecho Mercantil

Revista de Derecho Privado

Revista de Derecho de Sociedades

Revista de Derecho Inmobiliario

Reglamento

Revista Crítica de Derecho Inmobiliario

Revista de Derecho Concursal y Paraconcursal

Revista General de Derecho

Resolución Jurídica

Repertorio Cronológico de Jurisprudencia

Registro Mercantil

Responsabilidad Penal de Empleados

Responsabilidad Penal de Directivos

Reglamento del Registro Mercantil

Revista Jurídica Cataluña

Responsabilidad Social Corporativa

Responsabilidad Social Empresarial

Sentencia del Tribunal Constitucional

Sentencia del Tribunal Supremo

Sociedad anónima

Sentencia/Sentencias de la Audiencia Provincial

Sociedad Anónima Europea

Sociedad de Responsabilidad Limitada

Tomo

Tratado de la Comunidad Europea

Tribunal Supremo

Volumen

Véase 


\section{CAPÍTULO PRIMERO}

\section{LA CONFIGURACIÓN DEL ADMINISTRADOR DE HECHO EN}

LAS SOCIEDADES DE CAPITAL 


\section{INTRODUCCIÓN}

En la estructura interna de las sociedades de capital subyace un complejo entramado de relaciones que constituyen el ámbito de actuación de los administradores. De ahí que se haya considerado que, en su seno, existe un microestado presidido por un gobierno que son los administradores, y una asamblea soberana que es la junta general. Esta descripción de la sociedad en sentido figurado implica que el régimen de los administradores viene constituido por los estatutos de cada sociedad bajo el amparo de todas las disposiciones normativas que contiene la legislación societaria y, en concreto, por la Ley de Sociedades de Capital ${ }^{1}$.

No obstante, en las sociedades de capital se apreciaba una perpetua insatisfacción respecto a la actuación de los administradores, en especial por los abusos constatados tras la reciente crisis económica. Abusos derivados del exceso de poder que los administradores ostentaban, en particular, en las grandes sociedades $y$, sobre todo, porque en algunas sociedades su administración se encontraba dirigida por personas extrañas para eludir la responsabilidad de los administradores ${ }^{2}$. A estos efectos, la Ley 31/2014, por la que se modificó la Ley de Sociedades de Capital para mejorar el gobierno corporativo, incorporó la definición del administrador de hecho en su art. 236.3 con la inclusión del administrador de hecho oculto. De esta manera, el administrador de hecho quedó sometido al cumplimiento de los deberes de los administradores cuando actuaba como si fuera un administrador, pues bajo la rúbrica de los presupuestos de la responsabilidad se configuró su concepto legal como un hecho por su modo de actuar, cuando actuara como si fuera administrador. Así, dicho precepto establece que, "A tal fin, tendrá la consideración de administrador de hecho tanto la

\footnotetext{
${ }^{1}$ Explicando este entramado de relaciones internas y externas de la sociedad que comprenden las complejas actuaciones de los administradores como un micro estado pero en un sentido figurado, véase DÍAZ ECHEGARAY, J. L., El administrador de hecho de las sociedades, Ed. Aranzadi, Pamplona, 2002, p. 19.

${ }^{2}$ Poniendo de manifiesto esta situación paulatina de abuso de poder de los administradores, véase DÍAZ ECHEGARAY, J. L., Deberes y responsabilidad de los administradores de sociedades de capital: conforme a la Ley 26/2003, de 17 de julio, Ed. Thomson Aranzadi, Pamplona, 2004, pp. 2025. Sobre la implicación de los socios mayoritarios en las grandes empresas para la adopción de las decisiones del gobierno, GUERRA MARTIN, G., "El gobierno de las sociedades estadounidense. Su influencia en el movimiento de reforma del Derecho Europeo", $R d S$, núm.20, Ed. Aranzadi, 2003, p. 197. Detallando el poder de los administradores para la dirección de la sociedad, MARTÍNEZ SANZ, F., "La efectividad del control preventivo por parte del consejo: estrategia de negocios, optimización de recursos, definición de factores de riesgo y estructura de grupo (las políticas corporativas como directrices de gestión)", en AA.VV., Cuaderno de derecho para ingenieros. Hacia un nuevo gobierno corporativo (reforma desde la desconfianza de los mercados),(Coord. ALONSO UREBA), Ed. La Ley, 2013, pp. 31-45, pp. 33-35.
} 
persona que, en la realidad del tráfico, desempeñe sin título, con título nulo o extinguido, o con otro título, las funciones propias de administrador, como en su caso, aquella bajo cuyas instrucciones actúen los administradores de la sociedad”. Con esta definición se engloba una combinación muy amplia de personas que podrían alcanzar tal consideración, ya que el legislador tenía la pretensión de lograr el máximo control posible sobre el órgano de administración ${ }^{3}$.

La Ley 31/2014 tuvo como antecedente a la Comisión de Expertos creada por el Acuerdo del Consejo de Ministros de 10 de mayo de 2013 que tenía por finalidad "analizar la situación del buen gobierno en España con el objetivo de proponer medidas para la mejora de la eficacia y responsabilidad en la gestión de las sociedades"4. Sus propuestas se basaron en los principios elementales del gobierno corporativo, ya que el gobierno de todas las sociedades se encontraba bajo una forma organizativa muy deficiente, sobre todo por la grave crisis financiera de aquel momento. Por esta razón, se necesitaba que esta Comisión elaborara propuestas que mejoraran la eficacia en la gestión de las sociedades ${ }^{5}$. A tal fin, diferenció las propuestas dirigidas a mejorar el gobierno corporativo en el sistema normativo societario de las recomendaciones dirigidas a modificar el Código Unificado de Buen Gobierno (en adelante, CUBG) centrado en las sociedades cotizadas. No obstante, algunas pasaron a aplicarse con carácter general en la Ley 31/2014, ya que la misma se acercaba a los criterios que aconsejaban compaginar el interés común de los socios con el interés de otros grupos ${ }^{6}$.

${ }^{3}$ Advirtiendo que la definición de administrador de hecho en un sentido amplio puso límite a la continua disputa entre los conceptos de dirección y control, véase HERNADO CEBRIÁ, L., "Presupuestos del deber de lealtad: artículo 227.1", en AA.VV., Régimen de deberes y responsabilidad de los administradores en las sociedades de capital (Coord. HERNANDO CEBRIÁ), Ed. Bosch, Barcelona, 2015, pp. 137-181.

${ }^{4}$ Señalando los importantes escándalos financieros que se originaron en el siglo XXI como el caso Enron, World com o Parmalat en los anales del fraude y engaño, véanse EMBID IRUJO, J. M., "La mejora del gobierno corporativo y el régimen de deberes y responsabilidad de los administradores en las sociedades de capital", en AA.VV., Régimen de deberes y responsabilidad, cit., pp. 27-58; MESÍA MARTÍNEZ, C., "El procedimiento de denuncia interna o whistle blowing en los código de conducta", en AA.VV., Gobierno corporativo: la estructura del órgano de gobierno y la responsabilidad de los administradores" (Dir. MARTÍNEZ-ECHEVARRÍA Y GARCÍA DUEÑAS), Ed. Thomson Reuters Aranzadi, Cizur Menor, 2015, pp. 1208-1249.

${ }^{5}$ Explicando el problema de control de los administradores y sus ejecutivos, véase ESTEBAN VELASCO, G., "La renovación de la estructura de la administración en el marco del debate sobre el gobierno corporativo", en AA.VV., El gobierno de las sociedades cotizadas (Coord. ESTEBAN VELASCO), Ed. Marcial Pons, Madrid, 1999, pp. 137-209.

${ }^{6}$ Se configuró el concepto del interés social como "la consecución de un negocio rentable y sostenible a largo plazo "para promover el "máximo valor de la empresa". Para mayor estudio, véanse ALONSO UREBA, A., "El modelo de consejo de administración de la sociedad cotizada tras la 
De modo que, el nuevo CUBG de 24 de febrero de 2015, modificado y actualizado por la citada Comisión, tuvo dos objetivos fundamentales ${ }^{7}$ El primero, velar por el buen funcionamiento del órgano de administración para todas las sociedades $y$, el segundo, conseguir la confianza de los socios e inversores para mejorar el control interno, como la responsabilidad corporativa de las sociedades ${ }^{8}$.

Sin embargo, el legislador a la hora de elaborar la Ley 31/2014 no solo tuvo en cuenta las propuestas de la Comisión de 2013 que transformó en normas imperativas, sino que además adoptó otras que procedían de la proyectada propuesta de Código Mercantil de 17 de junio de 2013 (en adelante, PCM), como recomendaciones voluntarias incorporadas en las modificaciones del CUBG9. No obstante, la citada LSC definió el concepto de administrador de hecho en el art. 236.3, sin tener en cuenta que en el art. 215.8 PCM se establecía la extensión de los deberes de lealtad al administrador de hecho y a los accionistas de control, pues la Ley optó por regular la responsabilidad del administrador de hecho en un sentido amplio para que cumpliera todos los deberes de los administradores y no eludieran su responsabilidad.

reforma legal de 2014 y el CBG de 2015", en AA.VV., Junta General y Consejo de administración en la sociedad cotizada (Coord. RONCERO SÁNCHEZ), t. II, Ed. Aranzadi, Cizur Menor, 2015, pp. 27147; EMBID IRUJO, J. M., "La responsabilidad social corporativa ante el Derecho mercantil", Cuadernos de Derecho y Comercio, núm. 24, 2004, p. 26; MATEU DE ROS CEREZO, R., El Código Unificado de Gobierno Corporativo, Ed. Aranzadi, Madrid, 2007, pp. 52-53.

${ }^{7}$ Ver por todos, la recomendación décimo segunda del CUBG de 2015.

${ }^{8}$ Para mayor estudio sobre el Código de Buen Gobierno de 2015, véanse GUERRA MARTíN, G., "Las políticas societarias como facultades indelegables del consejo de administración. Y, en particular, las políticas sobre definición de la estructura y gobierno del grupo y sobre gobierno corporativo de la sociedad (arts. 249 bis b) y 529 ter.1. c), e) y g) LSC)", en AA.VV., Junta General y Consejo de administración, cit., pp. 1250-1288; VÁZQUEZ RUANO, T., "El buen gobierno corporativo de las sociedades cotizadas. Aproximación al régimen de los consejeros independientes", en AA.VV., Estudio sobre la responsabilidad de los administradores de las sociedades de capital a la luz de sus recientes reformas legislativas y pronunciamientos judiciales (Dir. DÍAZ MORENO Y VÁZQUEZ CUETO), Ed. Aranzadi, 2018, Cizur Menor, pp. 209-235.

${ }^{9}$ Las recomendaciones 7,8 y 31 del CUBG y la generalización de la regla cumple o explica que obligó a todas las sociedades cotizadas a informar sobre los códigos de buen gobierno se establecieron por la Directiva 2006/46/CE en el art. 61 bis g) de la Ley del Mercado de Valores, véase MARTÍNEZ ECHEVARRÍA Y GARCÍA DUEÑAS, A., "La defensa del interés social y la titularidad del patrimonio social como elemento determinante del gobierno corporativo", en AA.VV., Gobierno corporativo, cit., pp. 95-133. 
Por consiguiente, la doctrina del gobierno corporativo vio su luz en las sociedades españolas por tres motivos principales ${ }^{10}$. El primero, definir e implementar una política seria en materia de gobierno corporativo y, para ello, fueron incorporando las recomendaciones más utilizadas por las sociedades a nuestros textos legales, entre ellas, la consideración de administrador de hecho ${ }^{11}$. El segundo, la lógica que impartían los principios del gobierno corporativo que propiciaron que fueran objeto de inspiración para la confección de nuestras Leyes societarias ${ }^{12}$; lo que se tradujo en que el legislador estableciera un régimen jurídico distinto para regular las sociedades, pues era imposible configurar a las sociedades anónimas (en adelante, SA) abiertas al mismo nivel que las sociedades de responsabilidad limitadas (en adelante, SRL). No obstante, la definición legal del administrador de hecho se configuró sin hacer distinción entre los distintos tipos de sociedades $^{13}$. Y tercero, la introducción del administrador oculto sujeto a la responsabilidad ${ }^{14}$.

${ }^{10}$ Explicando las crisis empresariales a principios del año 2000 y la imposición de la obligación de explicar el por qué se apartan de estas recomendaciones, tal y como dispone el art. 61 bis g) Ley del Mercado de valores, véanse ALONSO UREBA, A., "Liderazgo en el consejo vs liderazgo en la dirección (la interactividad entre supervisión y la dirección efectiva)", en AA.VV., Cuaderno de derecho para ingenieros, cit., pp. 13-30. Un análisis detenido de los diferentes aspectos de esta regla, LÓPEZ QUESADA MARTÍN, E. Y CAMACHO MIÑANO, M. M., "Códigos de Gobierno suficientes para afrontar la crisis", Contabilidad, núm. 237, noviembre, 2011, p. 52. Y defendiendo este concepto del interés en su concepción amplia RODRÍGUEZ RUÍZ VILLA, D., "Límites legales a la actuación de los administradores de la sociedad opada (art. 60 bis LMV) y desarrollo reglamentario", $R d S$., núm. 35, 2016, p. 12.

${ }^{11}$ En este sentido, véase la opinión de HIERRO ANIBARRO, S., "Gobierno corporativo sin mercado de valores", en AA.VV., Gobierno corporativo en sociedades no cotizadas (Dir. HIERRO ANIBARRO), Ed. Marcial Pons, 2014, pp. 17-35. RODRÍGUEZ DE LAS HERAS BALLELL, T., "Requisitos para ser administrador y la extensión subjetiva de la responsabilidad", en AA.VV., Gobierno corporativo, cit., pp. 733-761.

${ }^{12}$ En España, la similitud del sistema norteamericano la podemos encontrar en las sociedades cotizadas, aunque con ciertas particularidades. Entre las diferencias que podemos señalar se encontraban que el capital era distribuido entre muchos accionistas y, normalmente, los grupos de accionistas mayoritarios controlaban toda la gestión de los administradores y que, a modo de $v$. gr., señalamos el caso concreto de los grupos de sociedades. Para mayor estudio sobre el dominio de los grupos de sociedades en el sistema societario véanse EMBID IRUJO, J. M., "Grupos y gobierno corporativo" en AA.VV., El gobierno de las sociedades cotizadas, cit., pp. 595-612; FERNÁNDEZ DE LA GÁNDARA, L., Y SÁNCHEZ ÁLVAREZ, Ma.., "El debate actual sobre el gobierno corporativo: aspectos metodológicos y de contenido", en AA.VV., El gobierno de las sociedades cotizadas, cit., pp. 55-91. Estas diferencias entre las grandes SA y las pequeñas SA, véase MARTÍNEZ-ECHEVARRÍA Y GARCÍA DUEÑAS, A., "La defensa del interés social”, cit., pp. 103104.

${ }^{13}$ Estableciendo una exposición sobre la mejora del gobierno corporativo en relación con los deberes y responsabilidad de los administradores y su extensión a la definición de administrador de hecho, EMBID IRUJO, J. M., "La mejora del gobierno corporativo y el régimen de deberes y responsabilidad de los administradores", cit., pp. 27-29. Un análisis detenido de los diferentes aspectos de la referida reforma puede encontrarse en MATEU DE ROS CEREZO, R., Practica de Gobierno 
De modo que, la Ley 31/2014 tuvo como centro de atención lograr un mejor reparto de poderes en la estructura orgánica de las sociedades de capital y reforzar el control del comportamiento de los administradores para que se garantizara el ejercicio prudencial de su poder en las sociedades ${ }^{15}$. En definitiva, introdujo en la legislación societaria algunos de los aspectos organizativos de aquellas prácticas de "Soft Law" o recomendaciones de Buen Gobierno. A modo de ejemplo, podemos citar la recomendación del Informe Aldama que aconsejaba la extensión de los deberes de lealtad a las personas que desempeñaban una posición similar a la de los administradores y al administrador oculto; en concreto, que se regulara la pieza fundamental del gobierno corporativo que no es otro que el régimen de la responsabilidad de los administradores, con la inclusión del administrador de hecho como administrador societario.

Así pues, nuestra legislación societaria se ha ido adaptando de forma paulatina a los continuos cambios económicos y políticos para tratar de equilibrar la constante lucha y reparto del poder de control y de dirección entre los administradores y la junta general con la amplia definición de administrador de hecho, que ha quedado sometido a los deberes relativos al ejercicio de las funciones propias de los administradores y su régimen de responsabilidad ${ }^{16}$. No obstante, por su falta de designación formal y por ser precisamente un hecho, esta figura necesitará de su correspondiente prueba y de sus posibilidades de actuación para cumplir con

Corporativo; La Reforma de la Ley de Sociedades de Capital y del Código de Buen Gobierno, Ed. Thomson Reuters Aranzadi, Cizur Menor, 2015, pp. 15 y ss.

${ }^{14}$ El administrador de hecho oculto ya era reconocido por nuestra doctrina como persona responsable de los deberes de los administradores cuando actuaba dando instrucciones a los administradores formales, véase, PAZ-ARES RODRÍGUEZ, C. Y VELASCO CABALLERO, F., "La responsabilidad de los administradores como instrumento de gobierno corporativo", $R d S$, núm. 20, 2003, pp. 67 y ss.

${ }^{15}$ Véase, ALBIÑA CIVLETI, C., "Líneas generales de la Ley de Sociedades de Capital”, en AA.VV., Comentario Práctico a la nueva normativa de gobierno corporativo (Dir. ALBIÑA Y SUÁREZ LESO), Ed. Dikinson, Madrid, 2015, 17-24.

${ }^{16}$ Poniendo de manifiesto la regulación jurídica de la configuración de los administradores en nuestras sociedades GARCÍA DE ENTERRÍA, J., "Los deberes de conducta de los administradores", en AA.VV., La reforma de la Ley de sociedades de capital en materia de gobierno corporativo (Dir. GARCÍA DE ENTERRIA), Ed. Thomson Reuters-Aranzadi, Cizur Menor, 2015, pp. 61-79, y el control de los administradores con la regulación del administrador de hecho, RODRÍGUEZ DE LAS HERAS BALLELL, T., "Requisitos para ser administrador", cit., pp. 748-749. 
todos los deberes de los administradores, a los efectos de poder exigirle su correspondiente responsabilidad ${ }^{17}$.

\section{ANTECEDENTES DEL ADMINISTRADOR DE HECHO}

\section{Evolución del concepto de administrador de hecho}

Los primeros vestigios de los administradores surgieron en el siglo XVI con el nacimiento de las primitivas SA. Estas sociedades solo podían ser constituidas por los soberanos con decisiones gubernativas -llamadas octroi- y se encontraban regidas por unos directores con amplísimos poderes que, en un principio, eran nombrados por los reyes y, más tarde, por los accionistas que con forma de consejo designaban y vigilaban a estos directores, y que tenían el nombre de administradores ${ }^{18}$.

Con la llegada de la Codificación en el siglo XIX la regulación jurídica de los administradores fue llevada al Título Segundo de nuestro primer Código de Comercio de 1829 (en adelante, CCom) y bajo la rúbrica "De las sociedades mercantiles" 19 , donde el concepto de sociedad anónima quedo definido como nuestras SA actuales ${ }^{20}$. La entrada en el CCom significó una transformación sustancial en la configuración jurídica de los

17 SÁNCHEZ-CALERO GUILARTE, J., "Administrador de hecho hay que probarlo", http: //jsanchezcalero.blogspot.com.es/2014/06/administrador-de-hecho-hay-que-probarlo.html, 6 de junio de 2014, pp. 1-3.

${ }^{18}$ Explicando la compañía moscovita y el reinado de Isabel I de Inglaterra de 1552, la compañía española en 1557 y la compañía de las Indias orientales en 1601, véase MARTÍNEZ-ECHEVARRÍA Y GARCÍA DUEÑAS, A., "La defensa del interés social", cit., p. 100. URÍA GONZÁLÉZ, R., Derecho mercantil, Ed. Aguirre, Madrid, 1976, pp. 4-9.

${ }^{19}$ Art. 265.3 del Código de Comercio de 1829 sonde se defino el concepto de sociedad anónima "Puede contraerse la compañía mercantil: Creándose un fondo por acciones determinadas para girarlo sobre uno o muchos objetos, que den nombre a la empresa social cuyo manejo se encargue a mandatarios o administradores amovibles la voluntad de los socios, y esta compañía es la que lleva el nombre de anónima".

${ }^{20}$ La personalidad jurídica de la sociedad es un principio legal que consiste en la organización unitaria de un patrimonio reconocido por el ordenamiento positivo para ser titular de derechos subjetivos y obligaciones En esta misma línea de desarrollo, 1998 y significando la separación del patrimonio social y el patrimonio de los socios, el caso Salomón por la "House of Lords" en 1887, donde consagra la personalidad jurídica de la sociedad limitando con respecto a la responsabilidad de los socios por las deudas de la sociedad, véanse DE ANGEL YAGÜEZ, R., Doctrina del levantamiento del velo de la persona jurídica en la jurisprudencia", Ed. Cívitas, 1997, pp. 62-63; HIERRO ANIBARRO, S., El origen de la sociedad anónima en España. Ed. Tecnos, Madrid. 
administradores que obedecía al cambio fundamental de un nuevo estado de las SA, ya que se sustituyó la autorización administrativa por el tribunal de comercio $^{21}$; lo que significó la total privatización de las sociedades, con la consiguiente consideración jurídica de los administradores como mandatarios. De este modo los deberes y la responsabilidad de los administradores se regirían por las reglas del contrato del mandato, quedando excluidos de responsabilidad si causaban daños a terceros; al tiempo que los administradores abusaron de su poder propiciados por la inexistencia de control gubernativo y la ausencia de regulación en materia de responsabilidad ${ }^{22}$.

Para solventar esta situación se dictó el Real Decreto de 15 de abril de 1847 que, por primera vez, consideraba la responsabilidad de los administradores por los daños derivados por su actuación ${ }^{23}$. Sin embargo, esta mejora no fue recogida en el Código de Comercio de 1885 que, influenciado por el Code de Commerce Francés ${ }^{24}$, siguió manteniendo a los administradores bajo las reglas del contrato de mandato y respondiendo de sus actos solo

${ }^{21}$ Con el CCom. nace la terminología para designar la sociedad mercantil, véanse GARRÍGUES DÍAZ-CAÑAVATE, J., Y URÍA GONZÁLEZ, R., Comentarios a la ley de sociedades anónimas, revisada y puesta al día por MENÉNDEZ Y OLIVENCIA, t. I y II, Madrid, Ed. $3^{\text {a }}$, Cívitas Madrid, 1976, p. 551; PETIT CALVO, C., "El anonimato de la sociedad mercantil y la llamada responsabilidad limitada. Apuntes para la historia de las anónimas en el derecho español del siglo XX", en AA.VV., Tendencias actuales en la ordenación de control y el capital en las sociedades mercantiles (Dir. LEÓN SANZ), Ed. Marcial Pons, 2009, pp. 77-91; SÁNCHEZ CALERO, F, La sociedad cotizada en bolsa en la evolución del derecho de sociedades, Ed. Real Academia de la Jurisprudencia y Legislación, Madrid, 2001, p. 40; URÍA GONZÁLÉZ, R., Derecho mercantil, Ed. Marcial Pons, Madrid, 2002, pp. 223-224; VICENT CHULÍA, F., Introducción al Derecho mercantil, Ed. Tirant lo Blanch, Valencia, 2008, pp. 296 y ss.

${ }^{22}$ Exponiendo el obrar de los administradores de las primeras sociedades anónimas en el primer Código de Comercio, véase DÍAZ ECHEGARAY, J. L., Deberes y responsabilidad, cit., pp. 30-36.

23 Una exposición detallada sobre la codificación del derecho mercantil, véanse GACTO FERNÁNDEZ, E., Temas de historia del derecho: derecho del constitucionalismo y la codificación, Universidad de Sevilla, Sevilla, 1975, pp. 69-81; RUBIO GARCÍA-MINA, J., Sainz de Andino y la codificación mercantil, Consejo Superior de Investigación Científicas, Madrid, 1959.

${ }^{24}$ Véase el art. 31 de Code de Comerce de 1808 calificando a los administradores como mandatarios y el art. 122.3 del CCom de 1885 cuando, en su redacción original defendía la sociedad anónima como una sociedad "en que formando fondo común los asociados por partes o porciones ciertas, figuradas por acciones o de otra manera indubitada, encargan su manejo a mandatarios administradores móviles que representan a la compañía bajo una denominación propia”. Y en igual sentido el art. 156 CCom de 1885 cuando disponía en su redacción original que, "Los administradores de las compañías anónimas son sus mandatarios, y, mientras observen las reglas del mandato, no estarán sujetos a la responsabilidad personal ni solidaria por las operaciones sociales, y, si, por la infracción de las Leyes y estatutos de la compañía, ó por la contravención a los acuerdos legítimos de sus juntas generales, irroguen perjuicios y fueren varios responsables, cada uno de ellos responderá a prorrata". 
frente a la sociedad ${ }^{25}$. No obstante, una parte minoritaria de la doctrina ${ }^{26}$ ya advertía que la actividad que realizaba el administrador era más compleja que la prestada como simple mandatario, pues detentaban facultades de gestión internas similares a las de un contrato de servicios, y facultades externas como las del contrato de representación ${ }^{27}$ (el CCom de 1885 recogía esta calificación jurídica sin opción para exigirles responsabilidad). Esta postura era la defendida por la Teoría contractual, la cual sostenía que no se debería discutir la naturaleza de la relación del administrador con la sociedad porque el CCom establecía que los administradores eran meros gestores de intereses ajenos con la función de cumplir la voluntad de los socios dentro de los límites atribuidos ${ }^{28}$. Frente a esta postura, no faltaban críticas doctrinales sosteniendo que la teoría del mandato no era suficiente para explicar la relación entre administrador y sociedad, ya que la propia personalidad jurídica impedía que pudiera subsistir por sí sola y, por esta razón, se debería acudir a los administradores para su representación frente a terceros ${ }^{29}$.

Unos años más tarde las SA se regularon por la Ley sobre Régimen Jurídico de las Sociedades Anónimas de 17 de julio de 1951 (en adelante, LSA); ello significó un cambio trascendental en la configuración jurídica de los administradores, al abandonarse toda referencia al mandato y situarse la SA en la categoría de estructura corporativa. El nuevo planteamiento significó que el órgano de administración se incardinará en gestionar y representar a la sociedad, lo que supuso el nacimiento del administrador como el titular del

${ }^{25}$ Sobre la condición jurídica del administrador como mandatario, véase SIERRA HERRERO, A., Administradores de las sociedades mercantiles, Ed. Aranzadi, Cizur Menor, 2008, p. 35.

${ }^{26}$ Véase, en este sentido ESTEASÉN, P., Instituciones de Derecho mercantil, t. III, Madrid, 1892, p. 76. LANGLE Y RUBIO, E., Manual de Derecho mercantil español, t. I, Bosch, Barcelona, 1950, p. 587. OLIVENCIA RUÍZ, M., "El Consejo coordinador", en AA.VV., Estudios sobre órganos de las sociedades de capital, (Coord. JUSTE MENCÍA Y ESPÍN GUTIÉRREZ) V. II, Ed Aranzadi, Cizur menor, 2017, pp. 336-351.

${ }^{27}$ En sentido contrario para esta calificación de mandatarios y advirtiendo que la figura del administrador es más compleja, GARRIGUES DÍAZ-CAÑAVATE, J., Curso de Derecho mercantil, Madrid, 1936, pp. 265-266.

${ }^{28}$ Para el desarrollo de la teoría contractual, véase ESPEJO HINOJOS, R., Curso de Derecho mercantil, t. II, Ed. 10a, Bosch Casa, Barcelona, 1940, p. 50.

${ }^{29}$ En este sentido, véase POLO SÁNCHEZ, E., "Los administradores y el consejo de administración de la sociedad anónima (arts.123 a 143 de la LSA) en AA.VV., Comentario al régimen legal de las sociedades mercantiles, t. VI (Dir. URÍA, MENÉNDEZ Y OLIVENCIA), Ed. Cívitas, Madrid, 1992, pp. 21 y ss. 
órgano de administración ${ }^{30}$. A partir de ahí, se instauró un genuino régimen de responsabilidad porque la relación jurídica entre los administradores y la sociedad se conceptúo como un vínculo orgánico $\mathrm{y}$, de esta forma, los administradores ya eran considerados responsables jurídicamente frente a la sociedad, los accionistas y los acreedores societarios ${ }^{31}$.

En este marco, la primera referencia sobre el administrador de hecho en nuestro derecho societario se limitaba a aquel administrador que ostentaba un cargo que había caducado. En concreto, la Resolución de la Dirección General de Registros y el Notariado (en adelante, DGRN) de fecha 24 de junio de $1968^{32}$, lo refiere como aquel cuyo cargo ha caducado, aunque con criterio restrictivo, ya que el administrador de hecho solo tenía la finalidad de convocar la junta para el nombramiento del nuevo administrador.

En términos similares, la doctrina jurisprudencial societaria ${ }^{33}$ que, en Sentencia del Tribunal Supremo (en adelante, STS) de 4 de diciembre de 2002 (RJ 10415/2002), reconocía solamente a esta figura en el supuesto de un administrador que con el cargo caducado continuaba actuando para que la sociedad pudiera proseguir con la actividad empresarial, tal y como postulaban los defensores de la llamada teoría formalista, que ha sido catalogada como

${ }^{30}$ Sobre la distinción ente órgano y miembro del órgano, véase DÍAZ ECHEGARAY, J. L., Deberes y responsabilidad, cit., p. 69. LAVILLA RUBIRA, J. J., "Órgano", en Enc. Jur. Básica, Madrid, 1995.

${ }^{31}$ En torno al desarrollo de los administradores como órgano, véase GIRÓN TENA, J., Derecho de sociedades anónimas, Valladolid, 1951, p. 456. Estableciendo esta distinción, SÁNCHEZ CALERO, F., Los administradores en las sociedades de capital, Ed. Aranzadi, Cizur Menor, 2007, p. 40.

${ }^{32}$ Ver resolución de la DGRN de fecha 24 de junio de 1968 (RJ 3662/ 1968) por el transcurso de cinco años en el art. 145 del el Reglamento del Registro Mercantil (en adelante, RRM), en esta línea, véanse resoluciones de la DGRN cuando el cargo tuviera vicio o defecto y se continuaba ejerciendo funciones de administrador de 22 de octubre de 1974 (RJ 3970/ 1974); 3 de marzo de 1977 (RJ 2529/ 1977); 12 de mayo de 1978 (RJ 72529/ 1978); de 11 de junio de 1992 (RJ 5737/ 1992); 13 de mayo de 1993(RJ 4123/ 1993); 7 de diciembre de 1993 (RJ 9863/ 1993); 25 de abril de 1994 (RJ 3070/ 1994); 4 de julio de 1998 (RJ 6583/ 1998); 15 de febrero de 1999 (RJ 734/ 1999); 13 de mayo de 1998 (RJ 4123/ 1998); 15 de febrero de 1999 (RJ 734/ 1999).

${ }^{33}$ En esta línea se reconocía como administrador de hecho al que firmaba una letra de cambio en nombre de la sociedad cuando este carecía de administrador formal, véanse SSTS de 23 de marzo de 1998 (RJ 1482/1998) y de 24 de septiembre de 2001 (RJ 2001/7489) y también se declaraba al administrador de hecho por carecer la sociedad del nombramiento de órganos de administración ya que no era posible una sociedad sin la existencia de sus órganos sociales previsto imperativamente por la Ley y en STS de 4 de diciembre de 2002 (RJ 10415/2002) se calificaba como administrador de hecho al administrador con el cargo caducado pero como una excepción. 
la doctrina más antigua por haberse pronunciado, por primera vez, sobre qué debía entenderse por administrador de hecho ${ }^{34}$.

No obstante, con la promulgación de la LSA de 1951 surgió la cuestión de cómo calificar la relación entre el administrador y la sociedad, ya que este había adquirido una posición compleja al ostentar funciones ejecutivas y representativas. En ese sentido, empezaron a vislumbrarse las primeras críticas sobre la gestión de los administradores en la sociedad y la necesidad de corregir los excesos de poder, con la consiguiente problemática que se reflejó en dos posturas contrapuestas ${ }^{35}$. Un sector minoritario defendía la denominada Teoría orgánica, considerando que entre los administradores y la sociedad existía una relación de carácter orgánico con base en la calificación del administrador como un órgano, y que éste era el medio de actuación social en las operaciones con terceros. Para los defensores de esta postura la designación del administrador no existía porque tenía su origen en una declaración unilateral de la junta general sin necesidad de que el administrador manifestara su voluntad $^{36}$.

Por el contrario, el sector doctrinal mayoritario defendía la Teoría contractual, considerando que la declaración unilateral por la sociedad no era suficiente para poder establecer obligaciones para los administradores, ni tampoco para explicar el contenido de sus funciones. Por esta razón había que celebrar un contrato entre la sociedad y el administrador que regularía sus obligaciones ${ }^{37}$. De ahí que se diferenciaran dos relaciones entre los administradores y la sociedad. La primera, una relación orgánica por la que adquiriría la titularidad del órgano de administración y, la segunda, una relación contractual que regularía el ejercicio de sus actuaciones. De este modo, a los administradores se les identificaba como

\footnotetext{
${ }^{34}$ Para la doctrina formalista de influencia italiana, véase MINERVINI, G., Gli amministratori di società per azioni, Giuffrè, Milano 1956.

35 Véanse HERNÁNDEZ SÁINZ, E., La administración de sociedades de capital por personas jurídicas: régimen jurídico y responsabilidad, Cizur Menor, Madrid, 2014, pp. 32-34; SÁNCHEZ CALERO, F., Los administradores, cit., pp. 32-35.

${ }^{36}$ Defendiendo esta postura, véanse GARRÍGUES DÍAZ-CAÑAVATE, J. Y URÍA GONZÁLEZ, R., Comentarios a la ley de sociedades anónimas, cit., p. 73; SÁNCHEZ CALERO, F., Los administradores, cit., pp. 100-103.

${ }^{37}$ Los seguidores de esta postura, entre otros, GIRÓN TENA, J., Derecho de sociedades anónimas, cit., p 339; IGLESIAS PRADA, J. L., Administración y delegación de facultades en la sociedad anónima, Ed. Tecnos, Madrid, 1971; POLO SÁNCHEZ, E., "Los administradores". cit., p. 48.
} 
administradores cuando, en verdad, solo el órgano de administración era el administrador de la sociedad ${ }^{38}$.

Posteriormente, la evolución de los administradores como órgano culminó con la reforma parcial de nuestra legislación societaria para poder adaptarse a la Directiva 68/151/CEE, de 9 de marzo de 1968, y de esta forma los administradores tendrían un tipo de representación de contenido único e inderogable, según el cual la sociedad se obligaría frente a terceros por los actos que habían realizado sus representantes. De modo que, en toda nuestra legislación societaria el administrador se ha venido configurando como órgano social, tanto en el Texto Refundido de la Ley de Sociedades Anónimas de 1989, como en la Ley de Sociedades de Responsabilidad Limitada de 1995 (en adelante, LSRL), en la reforma de la Ley de Transparencia de 2003, que modificó sustancialmente los deberes y la responsabilidad de los administradores y, más recientemente, en la LSC que calificó a los administradores como un órgano en el art. 209 al referirse a sus competencias.

A la hora de abordar la relación jurídica que une al administrador de hecho con la sociedad se presentan otros aspectos muy diferentes a los expuestos. Principalmente porque en esta figura no aparece el acto unilateral de designación formal ni tampoco la aceptación del cargo, salvo en los administradores de hecho con título nulo o caducado que siguen ejerciendo funciones de administración. De ahí que la relación entre el administrador de hecho y la sociedad es de mera apariencia de su posición orgánica por el ejercicio de las funciones que son competencias de los administradores ${ }^{39}$.

No obstante, un sector doctrinal consideró que entre el administrador de hecho y la sociedad existe una relación de servicio que deriva de una vinculación contractual y que viene predeterminada por un contrato de arrendamiento con la sociedad con base en el consentimiento de la sociedad, porque es consciente de la existencia de ese contrato al admitir que el administrador de hecho realice las funciones del administrador ${ }^{40}$. De ahí que podrían

\footnotetext{
${ }^{38}$ Véase, SÁNCHEZ CALERO, F., Los administradores, cit., pp. 102 y ss.

${ }^{39}$ Con respecto, a la posición del administrador de hecho basada en la apariencia, véase LATORRE CHINER, N., "El concepto de administrador de hecho en el nuevo artículo 133.2 LSA", RDM, núm. 253, 2004, pp. 853-899.

40 Defendiendo esta postura, véanse PERDICES HUETOS, A., "Significado actual de los administradores de hecho, los que administran de hecho o los que de hecho administran. A propósito de la STS de 24 de septiembre 2001 (RJ 2001, 7489)", RdS, núm. 18, 2002, pp. 277-287; OLIVARES
} 
distinguirse dos relaciones, por un lado, una relación jurídica de servicios que regula los derechos y obligaciones recíprocas entre ellos y, por otro, una relación orgánica que dispone las competencias y las facultades o poderes, y también los deberes inherentes al cargo de administrador. En cambio, para cierto sector doctrinal, entre el administrador de hecho y la sociedad solo cabría una relación de servicios, rechazando la relación orgánica porque en esta no se distingue entre administrador de hecho y de derecho ${ }^{41}$.

Sin embargo, esta teoría no se llegó a aceptar en cuanto a la definición del propio concepto del administrador de hecho, ya que el art. 236.3 LSC se limitó a establecer la extensión subjetiva de la responsabilidad general de los administradores a las manifestaciones que se comprenden en su definición. Así, "Tanto la persona que en la realidad del tráfico desempeñe sin título, con título nulo o extinguido, o con otro título, las funciones propias de administrador, como en su caso, aquella bajo cuyas instrucciones actúen los administradores de la sociedad".

De manera que, actualmente, se ha configurado entre el administrador de hecho y la sociedad una relación jurídica orgánica con base en la obligación que este tiene de ejercer todos los deberes orgánicos de los administradores, y porque la evolución histórica del régimen jurídico de los deberes y la responsabilidad de los administradores terminó influenciada por los principios de los Códigos de Buen Gobierno ${ }^{42}$, a través de la Ley 31/2014, que configuró la responsabilidad del administrador de hecho. En ese sentido,

JAMES, J. M., "En tono a los administradores de hecho en la sociedad anónima", en Anales de la Academia Matritense del Notariado, 1978, pp. 267 y ss.

${ }^{41}$ También, en este sentido, véase BONELLI, F., "La responsabililità degli amministratori”, Tratado della società per azioni, Torino 1991, pp. 323-484.

${ }^{42}$ Un análisis detallado del nacimiento del movimiento del gobierno corporativo lo podemos encontrar en ALEJO GARMENDIA, B., Los deberes de diligencia y de lealtad de los administradores en las empresas, Ed. Thomson Reuters Proview, Cizur Menor, 2017, pp. 114 y ss. En esta línea, véase las empresas "market for corporate el sistema organizativo se encontraba deteriorado por dos aspectos fundamentales. El primero, marcado por la falta de eficacia de los mecanismos de control sobre las actividades de los administradores. Y, el segundo, consecuencia del primero porque las sociedades no contaban con paquetes accionariales significativos, para cesar a los administradores. Sin embargo, fue Europa uno de los grandes eslabones del movimiento del gobierno corporativo, sobre todo, en el Reino Unido con los principales Códigos de Buen Gobiern, del INFORME CADBURY de 1992 al INFORME HAMPEL de 1998, véase MARTÍNEZ ROSADO, J. "La Companies Act" de 2006 y las singularidades en materia de recomendaciones de gobierno corporativo características del Derecho inglés relativas al órgano de administración" en AA.VV., Junta general y Consejo de administración, cit., 1257-1288, y en Italia, véase BIANCO. M. Y CASAVOLA, P., "Corporate Governance in Italia: Alcuni fatti e problemi aperti”, Revista La Società, 1996, pp. 426 y ss. 
debemos resaltar que las modificaciones introducidas por la citada Ley ${ }^{43}$ fueron dirigidas a implementar una política sólida para poder conseguir la transparencia y el prestigio de las actuaciones de los administradores, con la introducción de la extensión subjetiva de la responsabilidad al círculo de personas que vienen citadas en la propia definición del administrador de hecho, en el art. 236.3 LSC. Además, por otra parte, también se extendió la responsabilidad de los administradores a los cargos de alta dirección, tal y como dispone el art. 236.4 de la LSC, así como a la persona física representante de la persona jurídica administradora contemplada por el art. 236.5 LSC.

\section{Aproximación a los orígenes del administrador de hecho en el derecho comparado}

Previamente al análisis del concepto jurídico vigente del administrador de hecho conviene referirnos a sus orígenes en el Derecho comparado, ya que nos arrojará algo más de luz en esta oscura cuestión. Su nacimiento obedeció a una instrumentalización de la organización corporativa de la sociedad, la cual se encontraba dirigida por personas que, sin formar parte del órgano de administración, participaban en la administración o influían en las decisiones de los administradores de forma sistemática. Así que, de forma paulatina, se fue configurando la doctrina del administrador de hecho.

Esta surge en el ordenamiento británico al ser los tribunales ingleses los que acuñaron la expresión de "administrador de hecho" o "director de hecho" en la segunda mitad del siglo $\mathrm{XIX}^{44}$. Este ordenamiento fue el que delimitó las dos manifestaciones del administrador de

43 Debemos enfatizar, principalmente, en las influenciadas que dimanaban del derecho estadounidense ya que la Ley 31/2014 incorporó algunas de aquellas normas en nuestro ordenamiento, entre otras, la conocida regla estadounidense la protección de la discrecionalidad empresarial conocida también como Business Judgment Rule, véanse EMBID IRUJO, J. M., "La mejora del gobierno corporativo", cit., pp. 27-29; GUERRERO TREVIJANO, C., El deber de diligencia de los administradores en el gobierno de las sociedades de capital, Ed. Thomson Reuteurs, Cizur Menor, 2014, pp. 44-81.

${ }^{44}$ Por primera vez, el término administrador de hecho aconteció en la Corte de apelación inglesa en el caso de "Recandina land reclaiming and Colonizinig Company, Coventry and Dixon's case de 1880", pues estableció que el que desarrolla una función de administrador de hecho no puede eludir los deberes y responsabilidad por esta actuación. Para un análisis más profundo sobre este concepto de administrador de hecho en el Derecho inglés, véanse DÍAZ ECHEGARAY, J. L., El administrador de hecho, cit., pp. 58-60; FELIÚ REY, J. Y RODRÍGUEZ DE LAS HERAS BALLELL, T., "La proyectada reforma del derecho de sociedades en el Reino Unido Companies Bill", Derecho de los Negocios, núm. 194, noviembre 2006, pp. 25-33; RODRÍGUEZ DÍAZ, I., "El administrador oculto", $R D B B$, núm. 138, 2015, pp. 14 y ss. 
hecho que aún hoy subsisten. La primera, cuando ejerce directamente las funciones de los administradores y, la segunda, el administrador oculto, cuando actúa de forma indirecta en la sombra.

De esta manera, el sistema británico fue uno de los principales países de referencia en los avances de esta teoría, estableciendo como regla general que la persona que ejerciera las funciones de administrar debía cumplir los deberes que la Ley preveía para los administradores. Esta regla fue reconocida como norma en el sistema británico en 1985 para evitar que estos sujetos eludieran sus responsabilidades, aunque actuaran sin título válido o detrás del órgano de administración ${ }^{45}$.

Así que, la doctrina del administrador de hecho en nuestro país fue cobrando cada vez una mayor importancia en la administración de la sociedad al ir gestándose como técnica para lograr atribuir la responsabilidad a las personas que se escondían o se amparaban en la protección dispensada por las reglas de la personalidad jurídica que, como es sabido, determinó que la responsabilidad solo operaría para los administradores formales dejando inmunes a los que intervenían de hecho. Al mismo tiempo, esta técnica propiciaría ir contra la actuación de aquellos socios que detentaban el poder de administrar (pues, desde las primitivas SA hasta las actuales se había producido un desplazamiento del poder hacia los socios mayoritarios en detrimento de los minoritarios que solo se preocupaban por sus dividendos y por el incremento del valor de sus acciones) ${ }^{46}$. Sin embargo, los accionistas mayoritarios fueron excluidos por el nacimiento de unos profesionales, denominados por la doctrina como tecnoestructura, es decir, técnicos que venían administrando de hecho a las sociedades con sus conocimientos ${ }^{47}$. Esta situación se complicó, aún más, con la aparición de los grupos de sociedades en las que difícilmente se podía averiguar quiénes eran los que realmente venían administrando a las sociedades filiales, ya como administradores de hecho

\footnotetext{
${ }^{45}$ Sección 741 del Company Act de 1985. Concretamente, el art. 231 in the Companies Acts, bajo la rúbrica "Meaning of "director" and "shadow director".

${ }^{46}$ Véase OLIVARES JAMES, J. M., "En torno a los administradores de hecho en la Sociedad Anónima" cit., p. 272.

47 El termino tecnoestructura se define como el grupo de asesores o técnicos que aportan conocimientos para las decisiones empresariales, véase GARBRAITH, J. K., El nuevo estado Industrial, Ed. Ariel Economía, Barcelona, 1984.
} 
de forma directa, ya de forma oculta ${ }^{48}$. De este modo, la concreción del administrador de hecho presentaba perfiles confusos, aunque se fuera consciente de la necesidad de dotar de cobertura legal a esta figura, y poco a poco se fuese vislumbrando cierto reconocimiento de la teoría del administrador de hecho en el ámbito societario, instaurándose como instrumento de disciplina para exigir responsabilidad a aquellas personas que se encontraban ejerciendo las funciones de administración en la sociedad.

Paralelamente, esta teoría se fue extendiendo a otros ordenamientos. En Italia el concepto de administrador de hecho apareció aproximadamente en la segunda mitad del siglo XIX en su ámbito penal, y desde esta disciplina fue aplicándose a las personas que ejercían las funciones de dirección sin nombramiento formal. Sin embargo, solo se habla del administrador indirecto sosteniendo que eran los que de hecho administraban la sociedad sometiendo a los administradores de la sociedad a su propio mando ${ }^{49}$. El concepto de administrador de hecho tenía una particularidad que se fundamentaba, esencialmente, en la utilización fraudulenta de los administradores designados por la sociedad y, por esta razón, la doctrina italiana reconocía la responsabilidad indirecta en el ámbito de actuación del llamado empresario oculto.

Esta postura era defendida por los que postulaban la denominada Teoría del socio tirano que entendía que se debería superar el principio fundamental de la limitación de la responsabilidad si el socio utilizaba la sociedad y, por esta razón, se derivaba responsabilidad al socio tirano, porque era quién realmente administraba la sociedad ${ }^{50}$. Frente a esta corriente aparecieron los defensores de la concepción Ascareliana, oponiéndose frontalmente a la teoría anterior. Su teoría se justificaba en que no podría derivar la responsabilidad a un socio tirano por la aplicación rigurosa de las normas que delineaban la estructura en las sociedades capitalistas. Sin embargo, la teoría del administrador de hecho no fue reconocida en el plano normativo del Derecho italiano, y por esta falta de regulación legal se tendría que acudir a la

48 En esta línea de desarrollo, véase EMBID IRUJO, J. M., "La responsabilidad de los administradores de la sociedad anónima tras la Ley de Trasparencia", $R C D I$, núm. 685, septiembreoctubre 2004, pp. 2379-2423; RODRÍGUEZ SÁNCHEZ, S., "La responsabilidad de los administradores de hecho, algunos supuestos controvertidos", en AA.VV., Estudios sobre la responsabilidad de los administradores, cit., pp. 127-128.

${ }^{49}$ Explicando la teoría del administrador indirecto, véase ASCARELLI, T., In tema di vendita di azioni, responsabilità degli amministratori. Amministratore indirecto, en Foro It., 1953, pp. 1630 y ss.

${ }^{50}$ Ver por todos, PENNISI, G., “Administratore de facto e Shadow director en el sistema giurídico inglese: quache spunto comparatistico", Revista La società, núm. 2, 2004, pp. 252-255. 
jurisprudencia para delimitar esta categoría. Desde el punto de vista jurisprudencial la equiparación entre el director y administrador societario era posible. La referencia al administrador de hecho se vino acentuando con base en el perfil funcional, es decir, aquella actividad que venía realizado la persona que actuaba como si fuera un verdadero administrador en la sociedad.

Por su parte, el Derecho francés reconoció legalmente la equiparación entre el administrador formal y el administrador de hecho a principios del siglo XX, como un sistema de tutela con una regulación muy rigurosa para su responsabilidad que servía como un remedio de garantía para los acreedores. La razón de ser de esta excesiva regulación encontraba su justificación en evitar que quién controlaba todos los negocios pudiera eludir su responsabilidad $^{51}$. En Francia la figura del administrador de hecho se equiparó con la del administrador de derecho de forma explícita por Ley 98/1985, de 25 de enero, calificándolo como administrador, tanto en su manifestación de administrador de hecho aparente como oculto. Sin embargo, el legislador francés solo enunció posibles administradores de hecho sin describir sus elementos constitutivos, limitándose a establecer las disposiciones penales y que serían aplicables "a todas las personas que directamente o por persona interpuesta hubiera ejercido la dirección, la administración o la gestión en el mismo sitio y lugar de los representantes legales". En cambio, la doctrina jurisprudencial francesa exigía que el sujeto no se limitara a una simple actuación de administrar, sino que además realizara una serie de actos positivos que demostraran una actuación considerable y no una mera actuación de poder en el control de la sociedad ${ }^{52}$. La doctrina francesa del administrador de hecho (dirigente de fait) englobaba a toda persona que, directamente o por persona interpuesta, ejerciera una actividad positiva e independiente en la administración, es decir, el administrador de hecho se integraba por la persona que manipulaba al dirigente legalmente investido por la sociedad ${ }^{53}$.

Por su parte, en el Derecho germánico, el administrador de hecho empezó a configurarse a finales del siglo XIX, identificándose como el sujeto que ostentaba un nombramiento tácito o inválido con conocimiento de los socios. Progresivamente esta

\footnotetext{
${ }^{51}$ Véase DÍAZ ECHEGARAY, J. L., El administrador de hecho, cit., pp. 54-68.

${ }^{52}$ Ver por todos, PEROCHON, F., Entresprisess en difficulté. Instruments de crédit et paiment, París, 2006, pp. 459-460.

${ }^{53}$ En este sentido, ver por todos LEVENEUR, L., "Situations de fait et droit privé, bibliothéque de droit privé", Libraire generale de Droit et de Jurisprudence, Paris, 1990, pp. 48 y ss.
} 
interpretación fue abandonándose hasta que se consolidó otra interpretación que consideraba que el administrador de hecho era el que ejercía las actividades de los administradores ${ }^{54}$. Así, el Derecho alemán aceptó la figura del administrador de hecho, el denominado Faktisker Ges Chaftsunhrere, como sujeto que, si bien carecía de una investidura formal, dirigía los negocios sociales. Se reguló esta gestión indirecta con una disposición expresa, llamada de responsabilidad de derecho accionarial, que sancionaba a quién inducía a los administradores y, por ello, obligaba al administrador de hecho a resarcir por los daños causados respondiendo solidariamente con los administradores.

En cambio, el Derecho norteamericano reconoció al administrador de hecho por la jurisprudencia, ya que el Common Law entendía aplicables todos los deberes fiduciarios a los accionistas mayoritarios en el contexto de las sociedades cerradas (Closely Held Corporation ). La razón de la referencia a los socios mayoritarios era debida a la gran influencia que estos ejercían en la administración de la sociedad, pues estas personas eran las que realizaban una administración directa en la compañía ${ }^{55}$.

\section{El concepto de administrador de hecho antes de la reforma de la Ley 31/2014}

Los inicios sobre la noción del administrador de hecho en nuestro país estuvieron mediatizados por la doctrina formalista de influencia italiana. Esta corriente de carácter restrictivo solo contemplaba al administrador de hecho cuando la persona había sido nombrada administrador y su cargo se encontraba caducado, con algún vicio en su designación, cuando se aceptaba tácitamente que siguiera realizando las actividades de los administradores o cuando su nombramiento no reunía las formalidades publicitarias previstas en el Registro Mercantil, si desempeñaba el cargo de administrador mientras que la sociedad no había encontrado a otra persona que le sustituyera o cuando no se había inscrito el cargo de la persona que le sucedería como administrador ${ }^{56}$. Es decir, era necesario un contrato con la

${ }^{54}$ Un estudio detallado de la figura del administrador de hecho en el ordenamiento alemán lo podemos encontrar en DÍAZ ECHEGARAY, J. L., El administrador de hecho, cit., pp. 60-63.

${ }^{55}$ Explicando el poder de los accionistas mayoritarios en las sociedades estadounidenses, véase GONZÁLEZ VÁZQUEZ, J. C., "El progresivo reforzamiento de la posición de los accionistas en las sociedades estadounidenses a partir de la "Sarbanes. Oxley Act de 2002", en AA.VV., Junta General y Consejo de Administración, cit., pp. 1341-1393.

${ }^{56}$ Véase DÍAZ ECHEGARAY, J. L., El administrador de hecho”, cit., pp. 157 y ss. 
sociedad, expreso o tácito, para poder fundamentar la exigencia de responsabilidad al administrador de hecho ${ }^{57}$. De esta forma, la calificación jurídica de administrador de hecho únicamente era posible cuando una persona administraba con un nombramiento por la sociedad y además había aceptado el cargo de administrador ${ }^{58}$.

En resumen, para la corriente formalista nunca podría merecer la consideración de administrador de hecho la persona que no había sido nombrada como administrador de derecho, a pesar de que hubiera realizado actuaciones con poderes para administrar. Es decir, lo único que cabría con respecto a este sujeto sería que su actuación se calificara igual a la realizada por un mero empleado de la sociedad.

La noción de administrador de hecho por ello presentaba perfiles confusos, ya que esta concepción no era suficiente para paliar el problema de las injerencias de otras personas en la administración de la sociedad. Surgió en contraposición otra postura mayoritaria que consideraba que la noción de administrador de hecho debería tener un alcance mucho más amplio que englobara a "aquel sujeto que ostenta de manera continuada y sistemática el poder de decisión de la sociedad en los mismos términos en que éste viene atribuido por ley al órgano de administración sin haber sido regularmente investido del correspondiente

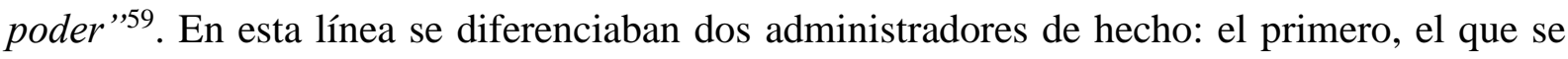
manifiesta frente a terceros, denominado administrador de hecho notorio y, el segundo, el que actuaba ocultamente detrás de los administradores formales, el denominado administrador oculto $^{60}$. En el mismo sentido se pronunciaba la jurisprudencia reafirmando que los

\footnotetext{
${ }^{57}$ Esta era la postura que sostenían que la relación entre el administrador y la sociedad era una la relación contractual, véase POLO SÁNCHEZ, E., Comentarios al régimen legal, cit., p. 52.

58 Esta concepción proviene del Derecho italiano y para un estudio con más detalle, véanse ABRIANI, N., "Gli amministratori di fatto della società de capitali", en Quaderni di Giurusprudenza Comérciale, Ed. Giuffrè. Milano 1998, pp. 183 y ss.; MINERVINI, G., Gli Amministratori di società, cit., pp. 109 y ss.

${ }^{59}$ Sobre ello, véanse ALONSO UREBA, A. Y PULGAR EZQUERRA., A., "Relación de grupo y administrador de hecho en el concurso de sociedades integradas en un grupo", $R d S$, núm. 28, 2007, pp. 25 y ss.; MARTÍNEZ SANZ, F., "Ámbito subjetivo de la responsabilidad", en AA.VV., La Responsabilidad de los administradores (Dir. ROJO Y BELTRÁN), Ed. Tirant Lo Blanch, Valencia, 2005 , pp. 58 y ss.

${ }^{60}$ Véase, GARCÍA-CRUCES GONZÁLEZ, J. A., "Administradores sociales y administrador de hecho", en Estudios jurídicos en homenaje al Profesor Sánchez de Andrés, Ed. Cívitas, Madrid, 1988, p. 7.
} 
administradores de hecho no deberían actuar bajo el mandato de los administradores formales cuando realizaran las funciones de un administrador societario ${ }^{61}$.

De ahí que la noción más generalizada de la figura del administrador de hecho se construyó sobre la base de dos pilares fundamentales. El primero, con base en las pautas de actuación de las personas que desarrollaban las funciones específicas de los administradores y, el segundo, basado en la ausencia de nombramiento que pudiera justificar su actuación como administrador ${ }^{62}$.

Por su parte, la postura doctrinal que defendía la llamada doctrina de la apariencia sostenía que el administrador de hecho se fundamentaba en aquella confianza que nos ofrecía la situación objetiva que creaba aquella persona que con su apariencia parecía un administrador. Así nos encontrábamos con la presencia del administrador de hecho por la apariencia que reflejaban las funciones que venía realizando, pues, componían la posición jurídica de un administrador con base en la apariencia de la posición orgánica que se desprendía de la propia actuación que venía realizando aquel sujeto ${ }^{63}$. Es decir, en la confianza que impregnaban estos sujetos en las personas cuando realizaban los actos de administración en nombre de la sociedad, aunque no obligaban a esta frente a terceros porque actuaban con un título viciado o porque carecían de un título societario. Y, por este motivo, el administrador de hecho solo nacería cuando el sujeto había realizado actos frente a terceros apoyándose en la necesidad de proteger a aquel tercero guiado por la apariencia y sin interesarle cuál era la relación con la sociedad de la persona que aparentaba ser administrador. Además, la sociedad había consentido la actuación realizada por el sujeto y, por ello, quedaba vinculada con aquel tercero que confió en tal apariencia.

Para los que postulaban esta doctrina de la apariencia, el recurso a la palabra "de hecho" tenía un doble objetivo. El primero, era poder conseguir que la realidad formal coincidiera con la sustancial y, el segundo, lograr que quien realizó el acto asumiera la

\footnotetext{
${ }^{61}$ En este sentido, véanse SSTS de 14 de marzo de 2007 (RJ 262/2007); de 8 de febrero de 2009 (RJ 79/2009); de 4 de febrero de 2009 (RJ 240/2009) y 4 de diciembre de 2012 (RJ 721/2012).

${ }^{62}$ En este sentido, véanse PERDICES HUETOS, A., "Significado actual de los administradores de hecho", cit., pp. 277 y ss.; PÉREZ ESCOLAR, R., "Los administradores de hecho y su actuación en el tráfico, $R D M$, núm. 108, 1968, pp. 339 y ss.

${ }^{63}$ En este sentido, véase LATORRE CHINER, N., "El concepto de administrador de hecho", cit., p. 875.
} 
responsabilidad y las consecuencias de su actuación. No obstante, hay que resaltar que esta doctrina solo consideraba que nos encontrábamos ante un administrador de hecho si el sujeto actuaba externamente y, en cambio, dejaba a un lado la calificación jurídica de administrador de hecho si el sujeto simplemente actuaba realizando un acto interno concreto como, v. gr., convocar la junta general, ya que esta actuación no se enmarcaba en la protección del tráfico mercantil, pues ese acto interno no podría vincular a la sociedad con un tercero por la apariencia de quien lo realizaba.

Otra razón que justificaba esta teoría era que siempre debía primar la seguridad jurídica y este fin solo se podría conseguir aplicando la justicia material, lo que se traducía en que solo podrían merecer la calificación jurídica de administrador de hecho aquellos sujetos que con apariencia actúan como tales en el ámbito externo de la sociedad. Los defensores de esta teoría restrictiva sostenían que el administrador de hecho solo nacía bajo la apariencia de cualquier título o sin título alguno cuando actuaba como un administrador con el consentimiento de la sociedad y en primera persona. Por esta razón dejaban fuera aquellos supuestos de influencia en la gestión de la sociedad ${ }^{64}$.

No obstante, los defensores de esta teoría se planteaban cómo debía resolverse la identificación de un administrador de hecho por su modo de actuar, es decir, como averiguaríamos si el sujeto que actuaba era un administrador de hecho o, en realidad, era un simple apoderado que con sus poderes solo realizaba funciones de gestión frente a terceros. Estimaron que todos los actos realizados por estos sujetos se debían considerar válidos con el fin de poder proteger a aquellos terceros que venían creyendo en la persona que actuaba como un administrador societario ${ }^{65}$. Esta doctrina no difería sustancialmente de la mayoritaria, pues también sostenían que en la noción de administrador de hecho se debía englobar a las personas que, sin el nombramiento de administrador, venían ejerciendo sus funciones cuando entablaban relaciones externas con terceros. Se trataba, en fin, del denominado administrador de hecho notorio.

\footnotetext{
${ }^{64}$ Explicando el sentido restrictivo del administrador de hecho, véase DUQUE DOMÍNGUEZ, J. F., "El concurso del grupo de empresas en la Ley Concursal", en AA.VV., Derecho Concursal. Estudio sistemático de la Ley 22/2003 y de la Ley 8/2003 para la reforma concursal, Ed. Dilex, Madrid, 2003.

${ }^{65}$ En esta línea se ha llegado a hablar de representante de hecho, véase CAVALLI, G. MARULLI, M., Y SILVETTI, C., “Le società per azioni, Ed. 3a, Torino, 1996, pp. 403 y pp. 512-515.
} 
Sin embargo, la doctrina formalista consideraba como administrador de hecho notorio a aquellas personas que no reunían las formalidades legales, ya fuera por caducidad del cargo o por algún vicio en su designación y, a pesar de estas carencias, continuaban ejerciendo sus funciones de administradores en la sociedad.

Al respecto, nuestra doctrina mayoritaria salvaba estas cuestiones reiterando que el elemento definitorio para poder identificar a un administrador de hecho debía de ser que la persona hubiera realizado actuaciones conforme a los cánones de las actividades de administración y de gestión empresarial ${ }^{66}$. De modo que, una simple actuación de administración o de gestión no se consideraba como conducta suficiente para que un sujeto pudiera alcanzar la calificación jurídica de administrador de hecho, debido a que deben añadirse otros requisitos en su actuación Así, el nacimiento del administrador de hecho se desprendía de la posición orgánica que el sujeto vendría ostentando en la sociedad cuando por su actuación, que era la de un administrador, ejercitara las funciones específicas del administrador en la sociedad ${ }^{67}$.

En síntesis, en la noción del administrador de hecho se diferenciaba entre una administración directa o aparente y la indirecta u oculta. Para los primeros, el concepto de administrador de hecho se configuraba con personas que solo actuaban en primera persona con la "apariencia de ser un administrador frente a terceros"; doctrina restrictiva que rechazaba al administrador oculto porque para lograr seguridad jurídica trataban de evitar que cualquier influencia se interpretara como una actuación del administrador de hecho ${ }^{68}$. Para los segundos, siempre lo consideraban en un sentido más amplio abarcando tanto a las personas que ejercían de forma directa funciones propias de administración como de forma indirecta, es decir, el llamado administrador de hecho oculto ${ }^{69}$.

\footnotetext{
${ }^{66}$ En esta línea se manifiesta LOZANO SAIGI, M., “Aproximación jurídica a la figura y régimen de responsabilidad del administrador de hecho", RJC, núm. 4, 2005, p. 88.

${ }^{67}$ Ver por todos, GARCÍA-CRUCES GONZÁLEZ, J. A., Administradores sociales y administrador de hecho, cit., pp. 7-12.

${ }^{68}$ Véase LATORRE CHINER, N., "El concepto de administrador de hecho", cit., p. 872- 877.

69 En sentido amplio sobre el concepto de administrador de hecho, véanse PAZ-ARES RODRÍGUEZ, C., Y VELASCO CABALLERO, F., "La responsabilidad de los administradores como instrumento de gobierno corporativo", cit., p. 17; PERDICES HUETOS, A., "Significado actual de los administradores de hecho", cit., p. 279; QUIJANO GONZÁLEZ, J., La responsabilidad civil de los administradores de la sociedad anónima, Universidad de Valladolid, 1985, p. 355.
} 
Por último, se defendía una clasificación diferente para integrar la noción de administrador de hecho, y se acogía como referencia su perfil funcional por el "modo de actuar" de aquellas personas que, sin título, gestionaban de hecho la sociedad y que se manifiesta a través de dos formas de actuación. La primera, bajo un título, v. g., apoderados, directores generales o cualquier otro título societario, y, para la segunda, cuando actuaban indirectamente bajo cualquier forma, fundamentalmente dictando instrucciones a los administradores de derecho que actuaban como testaferros u hombres de paja acatando las directrices del administrador de hecho oculto, o con el ejemplo paradigmático de los accionistas mayoritarios, socio único, proveedores de liquidez para la sociedad insolvente, entidades crediticias, franquicias, parientes o amigos de los administradores, trabajadores, etc. Lo relevante para merecer la calificación jurídica de administrador de hecho era que intervinieran ejerciendo funciones propias de los administradores ${ }^{70}$.

Esta misma postura doctrinal también defendía que la integración de la figura de administrador de hecho se debería construir diferenciando dos tipos de administrador de hecho, el administrador de hecho denominado "notorio" y el administrador de hecho denominado "oculto"71. Entendiendo que el administrador de hecho notorio, era aquel sujeto que, sin título, se encontraba ejerciendo funciones propias de administrador directamente en la realidad del tráfico mercantil, mientras que en el otro tipo de administrador de hecho, el oculto, se distinguía entre el que actuaba bajo la apariencia de otro título, $v . g r$, como un apoderado o un director ejecutivo u otro cargo societario, y el que actúa en la sombra, ocultamente, dando instrucciones a los administradores formales de la sociedad.

\section{Hacia la configuración del perfil funcional del administrador de hecho}

La doctrina penalista propugnó una equiparación entre administrador de hecho y de derecho con supuestos concretos referidos a la caducidad del cargo. Doctrina que se reflejó

\footnotetext{
${ }^{70}$ En esta línea, ya se ha pronunciado FUENTES NAHARRO, M., "La funcionalidad de la figura del administrador de hecho como vía de imputación de responsabilidades intra grupo (una aproximación a la delimitación conceptual de la figura)", II Harvard-Complutense Seminar on Business Law Corporate governance conflicts and corporate insolvency, www. ucm.es, 2006, pp. 1719.

${ }^{71}$ En este sentido, se pronunció la corriente que defiende PERDICES HUETOS, A., "Significado actual de los administradores de hecho", cit., p. 281.
} 
normativamente en el art. 31 del Código Penal (en adelante, CP) tras la reforma operada por la LO 10/1995, de 23 de noviembre, que reguló la responsabilidad personal del administrador de hecho como el representante de la persona jurídica ${ }^{72}$. Sin embargo, la doctrina societaria dudaba en reconocer de forma automática al administrador de hecho como un administrador de derecho, pues esta solo pretendía que las personas que venían ejerciendo funciones de gestión de forma regular sin designación formal respondieran por su actuación ${ }^{73}$.

En paralelo, la doctrina jurisprudencial avanzaba en el reconocimiento de la figura del administrador de hecho atendiendo a su perfil funcional. Este avance se trazaba con una proyección expansiva hacia aquella persona que ejercía como si fuera el administrador para poder eludir su responsabilidad, y poco a poco establecía un catálogo de posibles administradores de hecho ${ }^{74}$.

Con la llegada de los noventa se dejaron a un lado los criterios que defendía la teoría formalista y empezó a vislumbrarse en nuestra doctrina el predominio del perfil funcional, pues era doctrina pacifica que la calificación jurídica de administrador de hecho debería basarse en su forma de $\operatorname{actuar}^{75}$. Este perfil se construiría con indicios que señalarían actividades propias de la gestión de la sociedad ${ }^{76}$.

${ }^{72}$ En concreto, el art. $31 \mathrm{CP}$ señala: "El que actúe como administrador de hecho o de derecho de una persona jurídica, o en nombre o representación legal o voluntaria de otro, responderá personalmente, aunque no concurran en él las condiciones, cualidades o relaciones que la correspondiente figura de delito o falta requiera para poder ser sujeto activo del mismo, si tales circunstancias se dan en la entidad o persona en cuyo nombre o representación obre".

${ }^{73}$ Considerando la calificación de administrador de hecho en aquellos que ejercen el cargo de administrador de una manera efectiva, véanse GARCÍA PÉREZ, J. J., "La responsabilidad penal de los administradores de sociedades por impedimento o negativa del ejercicio de los derechos del socio y del ejercicio de la supervisora e inspectora de la Administración”, en AA.VV., La responsabilidad de los administradores de las sociedades de capital (Coord. GALÁN CORONA Y GARCÍACRUCES), Madrid, 1999, pp. 145-199; MATA MARTÍN, R. M., "La responsabilidad penal del administrador societario desleal. Estudio del delito del artículo 295 del Código Penal", $R d S$, núm. 12, 199, pp. 12 y ss.; QUIJANO GONZÁLEZ, J., "La responsabilidad civil de los administradores por no disolución de la sociedad y la causa de exoneración”, $R d S$, núm. 19, 2002, p. 331.

${ }^{74}$ Véanse, SSTS de 23 de marzo de 1988 (RJ 4730/1988); de 26 de mayo de 1988 (RJ 4004/1988); de 7 de junio de 1999 (RJ 4730/1999); de 24 de septiembre de 2001 (RJ 7489/2001); de 26 de mayo de 2003 (RJ 3926/2003); de 27 de octubre de 1997 (RJ 7617/1977); de 5 de abril de 1999 (RJ 2818/1999); de 26 de mayo de 2003 (RJ 3926/2003), donde enuncian un catálogo de supuestos típicos de administradores de hecho que coinciden prácticamente con los establecidos por la doctrina y jurisprudencia y en los que se reconoce mereciendo tal condición, al socio mayoritario, al apoderado general, al administrador no inscrito o con cargo caducado, etc.

${ }^{75}$ Ampliando el círculo de personas que pueden ser consideradas administradores de hecho con base en las tareas que desarrollen estas personas, véase PORFIRIO CAPRIO, L. J., "Administradores de 
De esta manera, la determinación del administrador de hecho se iba abriendo paso hacia las personas que, sin título, gestionaban de hecho la sociedad, aunque subsistía el criterio reduccionista que restringía su concepto a aquellas personas con nombramiento inscrito en el Registro Mercantil. No obstante, en este marco afloraban también como administradores de hecho las personas que ejercían la gestión sin título si la realidad demostraba que, de facto, venían ejerciendo funciones de gestión interna o externa en la sociedad ${ }^{77}$.

Tras un tiempo de calma sobre qué se entendía por administrador de hecho, entró en vigor la Ley 37/1998, de 16 de noviembre, de Reforma de la Ley 24/1988, de 24 de julio, del Mercado de Valores (en adelante, LMV). Concretamente, su art. 95 establecía que el administrador de hecho resultaría responsable si incumplía las normas de la disciplina del mercado de valores.

Al tiempo, van surgiendo los Códigos de Buen Gobierno (en adelante, CBG) con recomendaciones de cumplimiento voluntario que aconsejaban la manera de poder lograr un mejor gobierno para las sociedades cotizadas. El objetivo de estos Códigos era regular mecanismos de control para corregir los abusos de poder de los administradores y también de aquellos que actuaban como tales.

El primer reflejo de estas recomendaciones lo podemos encontrar en el Código de Buen Gobierno de 1998, denominado Código Olivencia, cuyo centro de atención se encontraba en el consejo de administración de las sociedades cotizadas. Este Código no obligaba a las sociedades a cumplir con el reconocido principio de la regla comply or explain, que actualmente es la regla que obliga a las cotizadas a que consignen el grado de seguimiento de las recomendaciones del gobierno corporativo o que expliquen el por qué no las cumplen. Por este motivo, se complementó con otras disposiciones normativas como, $v$. gr., la Ley 44/2002, de 22 de noviembre, también denominada Ley Financiera, que supuso

hecho y concurso: da mihi factum, dabo tibi ius", Revista de la Facultad de Derecho de la UNED, 2011 , p. 5.

${ }^{76}$ En esta línea, defendiendo el perímetro de los sujetos responsables y acogiendo a los administradores de hecho ocultos y a los altos directivos y a los accionistas de control PAZ-ARES RODRÍGUEZ, C., "La responsabilidad de los administradores", cit., pp. 51-53.

${ }^{77}$ En este sentido, véanse DÍAZ ECHEGARAY, J. L., El administrador de hecho, cit., pp. 46-76; MARTÍNEZ SANZ, F., “Ámbito subjetivo de la responsabilidad”, cit., pp. 54 y ss. 
que, por primera vez, se elevara a rango normativo la recomendación del Código Olivencia de que las sociedades contaran con un comité de auditoría.

Paralelamente, las recomendaciones de los CBG aconsejaban extender los deberes de lealtad a cualquier sujeto que ejercieran funciones de administrador, entre ellos, al administrador de hecho. En concreto, se definía como "aquella persona que en la realidad del tráfico desempeñan sin título o con título nulo o extinguido las anteriores funciones" "78. Este reconocimiento obedecía a la corrupción empresarial acentuada por la presencia de personas extrañas que habitualmente influían decisivamente en el proceso de decisión de los administradores $^{79}$.

El perfil funcional del administrador de hecho también empezó a vislumbrarse en el art. 89.3 RLSA, disponiendo que los directivos y las personas con poder de representación adquirirían la condición de administradores si realizaban las funciones propias de administración, y en el art. 127 del mismo texto donde se completaba la responsabilidad del administrador de hecho por el incumplimiento de los deberes de lealtad ${ }^{80}$.

Unos años más tarde apareció el Informe Aldama, fruto de los trabajos de una Comisión Especial ordenada por el Consejo de Ministros de 8 de enero de 2003, cuya misión era el establecimiento de "criterios y pautas para el buen gobierno de nuestras sociedades para aumentar la transparencia y seguridad en los mercados" "\$1. El Informe Aldama aconsejaba que se extendiera la responsabilidad de los deberes de lealtad al administrador de hecho, es decir, "a quienes, sin ostentar la posición formal de administrador, desempeñaban en la sociedad un papel similar" y, también, "a los altos ejecutivos de la sociedad, aunque no ostentaran la condición de consejeros" y "a los administradores ocultos, bajo cuyas instrucciones suelen actuar los administradores de la sociedad”. Además, generalizó la regla

\footnotetext{
${ }^{78}$ Véase, esta definición en el Informe de la Comisión especial para el fomento de la transparencia y seguridad en los mercados y en las sociedades cotizadas de 8 de enero de 2013, presidido por D. Enrique Aldama y Miñón, p. 25.

${ }^{79}$ Explicando las recomendaciones de nuestros Códigos, véase MATEU DE ROS CEREZO, R., Práctica del Gobierno Corporativo, cit., pp. 453 y ss.

${ }^{80}$ Véase LATORRE CHINER, N., "El concepto de administrador de hecho", cit., p. 857.

${ }^{81}$ Un análisis detenido de los diferentes aspectos del gobierno corporativo, véase ESTEBAN VELÁSCO, G., "La renovación de la estructura de la administración en el marco del debate sobre el gobierno corporativo", cit., pp. 148-159.
} 
cumple o explica en las sociedades cotizadas ${ }^{82}$. Así que el Informe Aldama conceptuaba al administrador de hecho como la persona que actuaba gestionando la sociedad sin posición formal de administrador y al administrador oculto como aquella persona que impartía instrucciones a los administradores ${ }^{83}$.

Consecuencia directa del Informe Aldama fue la Ley 26/2003, de 17 de julio, comúnmente llamada Ley de Transparencia, que supuso una reforma sustancial en la LSA, principalmente en materia de deberes y responsabilidad de los administradores. La Ley de Transparencia tenía el objetivo de reforzar la transparencia e incluyó la obligación de adoptar determinados mecanismos de control en materia de gobierno corporativo. Se introdujeron modificaciones significativas, entre ellas, tipificar el deber de fidelidad en el art. 127 bis, el deber de lealtad en el art. 127 ter y el de secreto en el art. 127 quáter de dicha LSA, así como el reconocimiento del administrador de hecho en su art. $133^{84}$. La incorporación de esta figura supuso que la persona que actuara como si fuera administrador quedaría sujeto al cumplimiento de los deberes de los administradores y a su régimen jurídico de responsabilidad. Sin embargo, la Ley de Transparencia no definió qué se entendía por administrador de hecho, a pesar del intenso trabajo doctrinal sobre el concepto de

${ }^{82}$ Explicando el Informe Aldama, véase OLIVENCIA RUÍZ, M., "El buen gobierno de las sociedades y su evolución”, en AA.VV., Tendencias actuales en la ordenación del control y el capital en las sociedades mercantiles (Dir. LEÓN SANZ), Ed. Marcial Pons, 2009, pp. 11-64.

${ }^{83}$ El Informe Aldama de 8 de enero de 2003, fue fruto de la Comisión especial para el fomento de la transparencia y seguridad en los mercados y en las sociedades cotizadas y en su epígrafe III. 2.3 bajo la rúbrica de responsabilidad de los administradores: deberes de lealtad y diligencia aconsejaba la extensión subjetiva de los deberes de lealtad a determinadas personas, entre ellas, a las personas físicas que representan a las personas jurídicas administradoras, a los altos ejecutivos aunque no ostenten la condición de consejeros y al administrador de hecho, es decir, a aquella persona que en la realidad del tráfico desempeñaba sin título o con título nulo o extinguido las funciones de administrador y también, a los administradores ocultos, bajo cuyas instrucciones suelen actuar los administradores de la sociedad y a los accionistas de control. Para las concordancias del Informe Aldama con otras recomendaciones, véase MATEU DE ROS CEREZO, R., El Código Unificado de Gobierno Corporativo, cit., pp. 447-480.

${ }^{84}$ También, explicando las modificaciones establecidas por la Ley de Transparencia, véanse DÍAZ MORENO, A., Responsabilidad y deberes de los administradores (notas acerca del nuevo régimen introducido por la "Ley de Transparencia"), Madrid, IFEX, 2003; JUSTE MENCÍA, J. Y IGARTUA ARREGUI, J., "Deberes de los administradores (reforma de la LSA por la Ley de Transparencia)", $R d S$, núm.24, 2005, pp. 75-77; MATEU DE ROS CEREZO, R., La Ley de Transparencia en Sociedades Cotizadas (Ley 26/2003, de 17 de julio, de Modificación de la Ley del Mercado de Valores y de la Ley de Sociedades Anónimas), Ed. Thompson-Aranzadi, Cizur Menor, 2004, pp. 140 y ss. 
administrador de hecho ${ }^{85}$, aunque sí se reconoció por primera vez al administrador de hecho por su actuación en el art. 133.2 LSA ${ }^{86}$.

No obstante, la Ley Transparencia hizo algo más, llegando a extender los deberes y la responsabilidad a las personas que desempeñaran un papel de índole similar al que ejercía un administrador en la sociedad. En concreto, en el art. 132.2 LSA se señalaba que, "El que actúe como administrador de hecho de la sociedad responderá personalmente frente a la sociedad, frente a los accionistas y frente a los acreedores del daño que cause por actos contrarios a la Ley o a los estatutos o por los realizados incumpliendo los deberes que esta ley impone a quienes formalmente ostenten con arreglo a esta condición de administrador".

Si bien el Informe Aldama ya reconoció al administrador de hecho, por el contrario, la Ley de Transparencia se limitó a definir al administrador de hecho de una manera tácita ${ }^{87}$. De ahí que el concepto de administrador de hecho viniera ligado por su actuación, independientemente de si actuó con un cargo caducado, prorrogado o invalido, para que sirviera como un instrumento de protección frente a terceros, y de esta forma el administrador de hecho paso a ser responsable ${ }^{88}$.

No obstante, en nuestra legislación societaria subsistía un problema: la Ley de Transparencia se olvidó de definir qué se debería de entender por administrador de hecho,

\footnotetext{
${ }^{85}$ Sobre la trascendencia del reconocimiento del administrador de hecho en nuestra legislación, véase LATORRE CHINER, N. "El concepto de administrador de hecho", cit., p. 857 y ss.

86 Explicando esta reforma, véase EMBID IRUJO, J. M., "La responsabilidad de los administradores de la sociedad anónima tras la Ley de Transparencia”, cit., p. 2403.

${ }^{87}$ Sobre el estudio del régimen jurídico introducido a través de la Ley de Transparencia y la influencia de todos los Códigos de Conducta, véanse EMBID IRUJO, J.M., "Los deberes de los administradores en las sociedades cotizadas. El artículo 114 de la Ley del Mercado de Valores", $R D B B$, núm. 6, 2004, pp. 7 y ss.; FONT GALÁN, J. I., "El deber de diligente administración en el nuevo sistema de deberes de los administradores sociales", $R d S$, núm.25, 2005, pp. 71 y ss.; SÁNCHEZ CALERO, F., "Observaciones preliminares al proyecto de Ley de modificación del régimen de las sociedades cotizadas y de las anónimas en general, tras el Informe Aldama", $R d S$, núm. 20, 2003, pp. 27 y ss.

${ }^{88}$ Explicando el perfil funcional de la figura del administrador de hecho y el cumplimiento de los deberes por su modo de actuar, véase GARRETA SUCH, J. M., La Diligencia y responsabilidad de los Administradores y la contabilidad, Ed. Jurídicas y Sociales, S.A. Madrid, 2014, p. 21.
} 
pues solo mencionaba que, "el que actúe como administrador de hecho", es decir, el administrador de hecho respondería aun careciendo de definición real ${ }^{89}$.

Unos días antes de la aprobación de la Ley de Transparencia se promulgó la Ley 22/2003, de 9 de julio, Concursal (en adelante, LC). Esta Ley adelantándose a la Ley de Transparencia introdujo al administrador de hecho en los arts. 172.3, 48.3, 93 y 164.1, a fin de que esta figura pudiera responder personalmente cuando había omitido el deber de solicitar el concurso de la sociedad y, a causa de este incumplimiento, se hubiera generado o agravado la insolvencia de la sociedad ${ }^{90}$. La LC, aunque olvidó también definirlo, equiparó al administrador de hecho con el administrador de derecho con base en el predominio funcional de su actuación, y además indicó que respondería por esta omisión si se calificara el concurso como culpable.

También en el mismo año, la Ley 58/2003, de 17 de diciembre, que aprobó la Ley General Tributaria (en adelante, LGT) reconoció al administrador de hecho, regulando su responsabilidad subsidiaria expresamente en sus arts. 41 a $43^{91}$.

Unos años más tarde vio la luz el Código Unificado de Buen Gobierno de 2006, denominado Código Conthe (en adelante, CUBG) ${ }^{92}$, que refundió los principios del gobierno corporativo en un documento recopilatorio de las recomendaciones más significativas del

${ }^{89}$ En este sentido, también véase EMBID IRUJO, J. M., "Apuntes sobre los deberes de fidelidad y lealtad de los administradores de las sociedades anónimas", $C D C$, núm. 46, 2006, pp. 9 y ss.

${ }^{90}$ En materia de responsabilidad concursal para un estudio con mayor profundidad, véase GARCÍACRUCES GONZÁLEZ, J. A., "El problema de la represión de la conducta del deudor común", en AA.VV., La reforma de la Legislación Concursal (Dir. ROJO FERNÁNDEZ-RÍO), Ed., Marcial Pons, Madrid, 2003, pp. 304 y ss.

${ }^{91}$ Para mayor estudio sobre la responsabilidad de los administradores por las deudas tributarias, véase VILLAR EZCURRA, M., "La responsabilidad tributaria", en AA.VV., La responsabilidad, cit., pp. 468-512.

${ }^{92}$ El Código Unificado de Buen Gobierno de las Sociedades Cotizadas fue aprobado por el Consejo de la Comisión Nacional del mercado de Valores el 22 de mayo de 2006 y constaba de tres partes, la primera contenía los principios básicos donde se describían las características del Código donde se explicaba el principio de voluntariedad que impregnan todas las recomendaciones o principio de cumplir o explicar, en la segunda parte se desarrollaban las recomendaciones y en la tercera se realizaban las definiciones vinculantes de los términos utilizados en las recomendaciones, véase ALONSO UREBA, A., "El gobierno de las grandes empresas (Reforma legal versus Código de Conducta)", en AA.VV., El gobierno de las sociedades cotizadas, cit., pp. 95-133. 
Código Olivencia ${ }^{93}$ y del Informe Aldama. Su finalidad era conseguir la consonancia con las tendencias europeas para que todas las sociedades de capital se administraran de forma más adecuada y, sobre todo, con una mayor transparencia ${ }^{94}$.

Hay que señalar que estos tres textos de buen gobierno han venido realizando un trazado continuo sobre las mejores prácticas del núcleo central del gobierno corporativo que, como es sabido, comprende los mecanismos para realizar un control efectivo de las actuaciones de los administradores o, mejor dicho, de sus deberes y régimen de responsabilidad ${ }^{95}$. En un principio aquellas recomendaciones se dirigieron a las sociedades cotizadas, sin embargo, los principios rectores del gobierno corporativo se fueron incorporando a todas las sociedades de capital ${ }^{96}$ como reglas de funcionamiento en su gestión interna para controlar las actuaciones de los administradores en atención a las circunstancias y características de cada una ${ }^{97}$. Así que el CUBG de 2006 intentó solucionar el problema del administrador de hecho e incluyó la recomendación que recogía el Informe Aldama para los socios mayoritarios y los administradores ocultos extendiendo los deberes de los administradores ${ }^{98}$. En concreto, señalaba que, “Aquellas personas que en la realidad del tráfico desempeñan sin título o con título nulo o extinguido las funciones de administrador y a los administradores ocultos,

${ }^{93}$ Véase SÁNCHEZ ÁLVAREZ, M"a ., "El Código Olivencia y la responsabilidad de los miembros del Consejo de Administración", RdS, núm. 11, 1998, pp. 133-154.

${ }^{94}$ Los primeros vestigios del nacimiento del gobierno corporativo fue a comienzos del siglo XX en EEUU porque afloró un nuevo agente económico también conocido como gestor de las corporaciones, sin embargo, la aplicación de la doctrina de gobierno corporativo no llegaría a las sociedades hasta que se configuro la bien llamada empresa moderna, o mejor dicho, cuando las sociedades empezaron a poder vislumbrar que estas necesitaban en su régimen interno un sistema de organización que les pudiera servir para poder permitirse un refuerzo necesario para controlar aquellos abusos que los administradores venían ejerciendo en el poder cuando administraban las sociedades, véanse BERLE, A., Y MEANS, G., La modern corporation and private property, New York, 1932; RECALDE CASTELLS, A., "Los administradores de las sociedades anónimas en un entorno de buen gobierno", RVEH, INSS 1577-4163, núm. 6, 2003, pp. 51-77; VEBLEN, T., The theory of business enterprise, New York, 1990; VEBLEN, T., The Enginners and the price system, New York, 1924.

${ }^{95}$ Explicando el trazado de los Códigos de Buen Gobierno en nuestro sistema español en materia de gobierno corporativo, véase MARTíNEZ ROSADO, J., "La Companies Act de 2006", cit., pp. 12591260.

${ }^{96}$ Un análisis detallado del contenido y alcance de contenido de un Código de Buen Gobierno para las sociedades cerradas, véase ALEJO GARMENDIA, B., Los deberes de diligencia y de lealtad, cit., pp. 205 y ss.

${ }^{97}$ Sobre la responsabilidad en la gestión y el control del gobierno interno de las sociedades, véase PUY FERNÁNDEZ, G., "La responsabilidad social en el marco del gobierno corporativo", en AA.VV., Tendencias actuales en la ordenación y control, cit., pp. 193-207.

\footnotetext{
${ }^{98}$ En este sentido, véase la recomendación seis a) y b) del CUBG de 2006.
} 
aquellos bajo cuyas instrucciones suelen actuar los administradores de la sociedad y a los accionistas de control”.

De esta forma, poco a poco se fueron abandonando las primeras consideraciones de la doctrina formalista ${ }^{99}$, que solo consideraba como administrador de hecho a aquel sujeto con cargo caducado o con algún vicio, y se reconoció al administrador de hecho por su forma de actuar siguiendo la jurisprudencia penal, ya que el objetivo era que el que había actuado como administrador sin haber sido nombrado no pudiera eludir su responsabilidad ${ }^{100}$.

Después de un tiempo de calma, nuevamente, la LSA fue reformada por la Ley 19/2005, de 14 de noviembre, con el fin de introducir la denominada Sociedad Anónima Europea (en adelante, SAE) en su antiguo art. 126.3. Esta Ley recogía la referencia de administrador con el cargo caducado y dispuso que éste permaneciera administrando la sociedad hasta que la junta general nombrara a un nuevo administrador o cuando la junta no se había podido celebrar para nombrarlo. Hay que advertir que, aunque no se mencionaba al administrador de hecho expresamente, la doctrina entendía que, por su redacción, de nuevo se acogía la postura de que merecían la calificación de administrador de hecho aquellos administradores que provisionalmente continuaban administrando con el cargo cesado y seguían realizando sus funciones ${ }^{101}$.

Posteriormente, la Ley 1/2010, de 2 de julio, bajo la rúbrica de los presupuestos de la responsabilidad, incluyó en el art. 236.1 LSC al administrador de hecho junto al de derecho para que respondiera por el incumplimiento de los deberes de los administradores frente a la sociedad, los socios y los acreedores sociales. Sin embargo, el legislador olvidó, nuevamente, delimitar conceptualmente qué se entendía por un administrador de hecho, pues simplemente se refirió en el art. 236 LSC a "los administradores de hecho como tales", a diferencia del derogado art. 133.2 LSA que, al menos, acuñaba esta figura por su modo de actuar con la siguiente redacción, "el que actúe como administrador de hecho responderá personalmente".

\footnotetext{
${ }^{99}$ Explicando la doctrina formalista, véase DÍAZ ECHEGARAY, J. L., El administrador de hecho, cit., pp. 131-132.

${ }^{100}$ En esta línea, véanse SSTS de la Sala de lo penal, de 10 de noviembre de 1993 (RJ 8387/1993) y de 4 de mayo de 1994 (RJ 3651/1994).

${ }^{101}$ Véase MATEU DE ROS CEREZO, R., El Código Unificado de Buen Gobierno, cit., p. 217.
} 
Por último, señalar que en el Derecho comunitario el administrador de hecho fue objeto de una Propuesta de Directiva en torno a los grupos de sociedades, en la que se reconocía a esta figura como el dirigente de hecho de otra sociedad. Así, la sociedad merecería ser calificada como dirigente de hecho si ejercía directa o indirectamente una influencia sobre el órgano de administración de otra sociedad. La propuesta integraba al administrador de hecho aparente y al oculto con las mismas condiciones que a los administradores formales. También debemos citar la Propuesta de la Directiva sobre la sociedad unipersonal de responsabilidad limitada "Societas Unius Personae" (en adelante, SUP), de 9 de abril de 2014, que abordó la figura del administrador de hecho, aunque no se llegó a regular su concepto, a pesar de que nuestra doctrina se había venido manifestado sobre la manera de acoger esta figura ${ }^{102}$.

Por tanto, dada la falta de determinación de una definición legal de administrador de hecho se continuaba en la misma situación y, de ahí, que surgiera la problemática de seguir indagando sobre qué se entendía por administrador de hecho. Para solucionar este problema se recurrió al criterio doctrinal y jurisprudencial, así las SSTS de 26 de mayo de 1998 (RJ 4004/1998) y de 7 de junio de 1999 (RJ 506/1999) que se centraban en el modo de actuar del sujeto $^{103}$.

Es de justicia reconocer la importancia de los pronunciamientos doctrinales y jurisprudenciales, así como los CBG, para la configuración del concepto. La culminación de la evolución de la configuración jurídica del administrador de hecho en el ámbito societario se produce con la Ley 31/2014, para la mejora del gobierno corporativo de las sociedades de capital. Esta Ley supuso el fin de la polémica que hasta ahora se venía predicando por la doctrina sobre el concepto del administrador de hecho y, a partir de entonces, la legislación societaria, por primera vez, definió al administrador de hecho en el art. 236.3 LSC.

${ }^{102}$ Sobre la integración de esta figura en la propuesta de esta Directiva, que fue enmendada por el Texto transaccional del Consejo de 28 de mayo de 2015, ver por todos ESTEBAN VELASCO, G., "La propuesta de la directiva sobre la "Societa unius personae" (SUP): las cuestiones más polémicas", Notario del siglo, 27 de marzo de 2015.

${ }^{103}$ En este sentido SSTS de 26 de mayo de 1998 (RJ 4004/1998) y de 7 de junio de 1999 (RJ 506/1999). FUENTES NAHARRO, N., "Una aproximación al concepto de administrador de hecho y a la funcionalidad de la figura en los grupos de sociedades", en AA.VV., Gobierno corporativo y crisis empresariales, Madrid, Marcial Pons, 2006, pp. 289-310; LATORRE CHINER, N., El administrador de hecho, cit., pp. 165-170; PAZ-ARES RODRÍGUEZ, C., "La responsabilidad de los administradores como instrumento de gobierno corporativo", cit., p. 17; PERDICES HUETOS, A., "Significado actual de los administradores de hecho", cit., p. 279; QUIJANO GONZÁLEZ, J., La responsabilidad civil de los administradores, cit., p. 351. 
Con la definición que se recogió en la LSC se consiguió así instaurar la igualdad entre el administrador de hecho y el de derecho bajo la justificación de que debe cumplir con los deberes de los administradores por su modo de actuar, al quedar sometido a los presupuestos de su responsabilidad toda aquella persona que ejerciera las funciones de un administrador societario, con independencia de cuál fuera el título con el que viniese actuando.

\section{LA EQUIPARACIÓN AUTOMÁTICA DEL ADMINISTRADOR DE HECHO COMO ADMINISTRADOR SOCIETARIO A LA LUZ DE SU DEFINICIÓN LEGAL}

\section{Delimitación previa}

La LSC establece en su art. 236.3 la definición legal del concepto de administrador de hecho, "tendrá esta consideración tanto la persona, que en la realidad del tráfico desempeñe sin título, con título nulo o extinguido, o con otro título, las funciones propias de administrador, como en su caso, aquella bajo cuyas instrucciones actúen los administradores de la sociedad".

El legislador para elaborar el concepto de administrador de hecho asumió que los deberes de los administradores y su responsabilidad se definen por y a quienes les son exigibles. Por esta razón, su concepto se vincula al modo de actuar en la sociedad ${ }^{104}$. De ahí que para identificar quién puede ser administrador de hecho en la sociedad deben distinguirse dos categorías. La primera, contempla el administrador de hecho con un título caducado o nulo que continúa administrando la sociedad, o bien sin título con nombramiento implícito de la sociedad; tipo denominado por la doctrina como administrador de hecho notorio $^{105}$.

La segunda, el administrador de hecho oculto en el que, a su vez, se distinguen dos tipos. El primero, el sujeto que actúa bajo la apariencia de otro título como, v. gr., apoderado o cualquier otro título, y el segundo, el que no se manifiesta externamente porque actúa

${ }^{104}$ En este sentido, véanse GARRETA SUCH, J. M., La diligencia, cit., p. 21; LATORRE CHINER, N., El concepto de administrador de hecho, cit., p. 864.

${ }^{105}$ Distinguiendo esta doble categoría de administradores de hecho ocultos, véanse PERDICES HUETOS, A., "Significado actual de los administradores de hecho", cit., pp. 277 y ss. RODRÍGUEZ DÍAZ. I., "El administrador oculto", cit., pp. 34. 
impartiendo instrucciones a los administradores de la sociedad, es decir, el que oculta su presencia con una intención manifiesta de que no se sepa su identidad.

No obstante, debemos partir de dos premisas. La primera, que el concepto de administrador de hecho debe ser entendido en sentido restringido porque la realidad y la apariencia jurídica normalmente coinciden, por lo que indiscriminadamente no se debe extender la responsabilidad de los administradores a cualquier sujeto que realizara alguna actuación de administración ${ }^{106}$.Y, la segunda que, para poder identificar al administrador de hecho, siempre debemos atender a las particulares circunstancias que concurren en cada supuesto, ya que no se puede negar la posibilidad de que bajo la apariencia de algunos cargos se puede esconder un administrador de hecho que se desvelará mediante las pruebas de presunciones, tal y como resulta de lo normado en el art. $1.225 \mathrm{del} \mathrm{CC.}$

En cambio, la $\mathrm{LSC}^{107}$ define al administrador de hecho en el sentido más amplio posible. Y por esta razón, consideramos que será conveniente establecer limitaciones para su calificación, si bien teniendo en cuenta que esta Ley lo configura con una función instrumental para evitar fraudes de aquellas personas que quieren evitar la aplicación de las normas imperativas y la responsabilidad de los administradores societarios ${ }^{108}$. De ahí la justificación de los diversos perfiles de administrador de hecho descritos en el art. 236.3 LSC, dada la necesidad de solucionar la realidad empírica del gobierno de las sociedades, ya que se demostraba que determinadas personas físicas o jurídicas se adentraban en la estructura de las sociedades utilizando testaferros insolventes para eludir su responsabilidad ${ }^{109}$. De este modo,

106 En torno a esta advertencia por la doctrina mayoritaria, véase FERNÁNDEZ DE LA GÁNDARA, J., "El régimen de responsabilidad de los administradores", en La Ley de Sociedades Anónimas. Supuestos, principios y problemas, en la responsabilidad del administrador en las sociedades, Boletín del Ilustre Colegio de Abogados de Madrid, núm. 5 de junio, 1997, pp. 47 y ss.

${ }^{107}$ En este sentido, LLEBOT MAJÓ, J. O., "Deberes y responsabilidad de los administradores", en AA.VV., La responsabilidad de los administradores de las sociedades mercantiles (Dir. ROJO FERNÁNDEZ RÍO y BELTRÁN SANCHÉZ) Ed. Tirant lo Blanch, Valencia, 2016, pp. 21-61.

${ }^{108}$ Sobre el concepto de administrador de hecho y su perfil funcional tras la reforma de la Ley 31/2014, véase RODRÍGUEZ DE LAS HERAS BALLELL, T., "Requisitos para ser administrador", cit., p. 752.

${ }^{109}$ En torno a este planteamiento, ver por todas las consideraciones de JUSTE MENCÍA, J., "En torno a la aplicación del régimen de responsabilidad de los administradores al apoderado general de las sociedades. Notas a la SSTS de 26 de junio de 1998, 7 de junio de 199 y de la AP de Valencia de 27 de septiembre de 1999”, $R d S$, núm. 12, 2001, pp. 444 y ss. Explicando este contexto VALPUESTA GASTAMINZA, E., "Equiparación con el administrador de hecho de la persona que tenga atribuidas 
con la definición legal del administrador de hecho cualquier persona podrá alcanzar esta calificación cuando ejerza funciones propias de los administradores ${ }^{110}$.

\section{La problemática que plantea la definición legal del administrador de hecho}

La problemática que presenta el amplio concepto legal de administrador de hecho se centra, en primer lugar, en resolver qué personas físicas o jurídicas pueden integrarse en los perfiles que dibuja la LSC, con especial referencia a su manifestación oculta y, en segundo lugar, cuáles son las pautas de actuación que nos permitirán demostrar qué sujeto actuará como administrador de hecho. En este sentido, se observa que la definición legal del art. 236.3 LSC se limita a dibujar un perfil funcional y no formal, configurando al administrador de hecho como un "hecho" que será necesario probar"111. Así, solo merece esta calificación los que desempeñen funciones propias de administradores.

Otro problema importante es que el art. 236.3 LSC no introdujo la nota esencial de habitualidad en la actuación realizada por el administrador de hecho; requisito esencial caracterizador del sujeto dentro del concepto de administrador de hecho, ya que sus actuaciones deben ser un ejercicio continuado y sistemático del poder de gestión en la dirección de la sociedad. Es decir, no se podrá considerar suficiente una mera acción puntual de gestión para que un sujeto pueda merecer la calificación jurídica de administrador de hecho. Este requisito ya fue reconocido por la Comisión que elaboró el texto original de la Ley 31/2014 y, a pesar de ello, no apareció en la definición legal ${ }^{112}$. Ante esta omisión, todos

facultades de más alta dirección (art. 236.4 LSC)", en AA.VV., Junta General y Consejo de administración, cit., pp. 663-661.

110 Véase en este sentido EMBID IRUJO, J. M, “Todos son (y serán) administradores", en http://commenda.es/actualidad_interior/234, 23 de diciembre de 2014/.

${ }^{111}$ En torno a la necesidad de la prueba de administrador de hecho, véase SÁNCHEZ-CALERO GUILARTE, J., "Administrador de hecho hay que probarlo", cit., pp. 1-3. En este sentido, nuestra doctrina jurisprudencial advierte que es indispensable que exista una carga probatoria ineludible que acredite la actuación de un verdadero administrador de hecho, véanse SSTS de 18 de diciembre de 2007 (RJ 904172007); de 16 de octubre de 2013 (RJ 588/2013); de 3 de abril de 2013 (RJ 208/2013) y de 24 de febrero de 2014(RJ 1147/2014).

${ }^{112}$ Indicando la falta de exigencia de habitualidad en la definición de administrador de hecho como pauta de actuación, véase JUSTE MENCÍA, J., “Art. 236. Presupuestos y extensión de la responsabilidad", en AA.VV., Comentario de la reforma del régimen de las sociedades de capital en materia de gobierno corporativo (Ley 31/2014), (Coord. JUSTE MENCÍA), Thomson Reuters, Cizur Menor, 2015, pp. 444-487. 
los sujetos activos en la gestión podrían convertirse en administradores de hecho, aunque su actuación no tuviera relación con la actuación que en realidad realiza el administrador de hecho. Así que el concepto de administrador de hecho adopta una fenomenología de posibles administradores de hecho que alcanzará a toda una gama de personas jurídicas, entidades de crédito, grupos de sociedades, etc., siempre que todos los supuestos presenten un elemento en común que es el que dibuja la forma de actuación. Es decir, que cada uno de ellos venga ejerciendo las funciones específicas de los administradores societarios ${ }^{113}$.

De ahí que, de nuevo, se nos plantea una cuestión fundamental, ¿qué criterios permiten identificar al administrador de hecho en la sociedad?, pues en el art. 236.3 LSC no se describe cómo deberán ser las concretas pautas de actuación de cada perfil que presenta la definición legal. Para averiguar quién es el administrador de hecho en cualquiera de sus tipos, notorio u oculto, debemos acudir de nuevo a los argumentos que habían sido esgrimidos por la doctrina y jurisprudencia sobre las pautas concretas de conducta que caracterizan su actuación.

Entre las notas confeccionadas por la doctrina para calificar la actuación del administrador de hecho destacan la habitualidad, es decir, cuando realice funciones propias de administración la continuidad en el tiempo y el control efectivo en la administración influyendo decisivamente en los administradores de derecho, hasta tal punto de que llegue a sustituirles prácticamente, o bien actuando de manera externa exponiéndose frente a los terceros bajo la cobertura de cualquier título o simplemente sin título ${ }^{114}$. Es decir, no bastan simples tareas realizadas por un sujeto, sino que serán necesarias continuas actuaciones que

113 Sobre las amplias figuras que se engloban en la definición de administrador de hecho RODRIGUEZ DE LAS HERAS BALLELL, T., "Requisitos para ser administrador y extensión subjetiva de la responsabilidad", cit., pp. 750-751.

${ }^{114}$ En torno a las pautas de actuación del administrador de hecho, véanse EMBID IRUJO, J., M., "Todos son (y serán) administradores", cit., p. 1; FUENTES NAHARRO, N., "Una aproximación al concepto de administrador de hecho", cit., pp. 289-308; GARRIDO DE PALMA, V. M., Y ARANGUREN URRIZA, F. J., "Protocolos y pautas de actuación de los administradores", en AA.VV., Régimen de deberes, cit., pp. 427-465; LATORRE CHINER, N., "El concepto de administrador de hecho", cit., p. 865 y ss.; PAZ-ARES RODRÍGUEZ, C., "La responsabilidad de los administradores como instrumento de gobierno corporativo", cit., p. 17; PERDICES HUETOS, A., "Significado actual de los administradores de hecho", cit., p. 279; SANCHO GARGALLO, I., "La extensión subjetiva del régimen de responsabilidad de los administradores de hecho y ocultos y a la persona jurídica representante del administrador persona jurídica (art. 236.3 y 5 LSC)", en AA.VV., Junta General y Consejo de administración, cit., pp. 613-632. 
indiquen una verdadera administración por aquella persona que merezca, por su actuación, la condición jurídica de administrador de hecho ${ }^{115}$.

No obstante, el administrador de hecho en su manifestación oculta es el que suscita mayor complejidad para su identificación, tanto porque actúa de forma oculta como por el amplio abanico de personas que abarca ${ }^{116}$, y precisamente por ocultar su verdadera identidad, aunque también serviría para identificarlo cuando actúa bajo la influencia de su poder en las decisiones del órgano de administración.

Por último, para evitar que cualquier persona fuera calificada como administrador de hecho se deberá matizar el perfil funcional, para lo cual utilizaremos otros recursos para identificarlo. Los recursos para poder identificar al administrador de hecho los encontraríamos en las presunciones o deducciones, es decir, deberemos observar un hecho relevante que haya sido realizado por una persona que actúa como un administrador y, a partir de ahí, deducir si la actuación realizada por esa persona se corresponde con la actuación realizado por un administrador societario ${ }^{117}$.

En resumen, para llegar a la conclusión de que nos encontramos ante la presencia de un administrador de hecho en cualquiera de sus categorías, dada la falta de concreción legal, debemos acudir a aquellas notas que caracterizan su actuación elaboradas por nuestra doctrina cuando no existía definición legal de esta figura ${ }^{118}$.

La configuración jurídica del administrador de hecho con base en su aproximación funcional servirá para proteger mejor los intereses en juego, permitiendo mitigar así los

115 En este sentido SÁNCHEZ CALERO GILARTE, F., “Administrador de hecho: ¡hay que probarloi", cit., p. 1-3.

${ }^{116}$ Para mayor estudio sobre cómo debe ser la forma de actuar de un administrador de hecho oculto, véase RODRÍGUEZ RUÍZ VILLA D. Y HUERTAS VIESCA, M. I., Responsabilidad de los administradores de las sociedades de capital, Prólogo VICENT CHULÍA, F., Aranzadi, Navarra, 2012, pp. 186-189.

${ }^{117}$ En este sentido, ver por todos EMBID IRUJO., J. L., "Todos son (y serán) administradores de hecho", cit., pp. 1-3. Y sobre los recursos para demostrar la presencia de un administrador de hecho RODRÍGUEZ DE LAS HERAS BALLELL, T., "Requisitos para ser administrador", cit., p. 752.

${ }^{118}$ En torno a las pautas de actuación del administrador de hecho, véase SANCHO GARGALLO, I., "La extensión subjetiva de la responsabilidad", cit., pp. 618-621. 
riesgos de que puedan escapar de su responsabilidad por causar daños a la sociedad, a los socios o a terceros.

\section{Las manifestaciones de los distintos tipos que la Ley define como administrador de hecho}

El concepto legal de administrador de hecho incardina un amplio abanico de personas. En aras a su clarificación delimitaremos sus manifestaciones de acuerdo con los perfiles que se recogen en el art. 236.3 de la LSC. La línea de desarrollo la realizaremos atendiendo a la tipología que la doctrina mayoritaria ha ido clasificando en función de los posibles sujetos que puede presentar un administrador de hecho en el ámbito societario.

\subsection{Administrador de hecho notorio}

En primer lugar, vamos a identificar el administrador de hecho denominado doctrinalmente "notorio", que es el que presenta irregularidades en su situación jurídica119 porque fue designado por la sociedad, pero carecía de título, por ser inválido o extinguido y continuaba ejerciendo su actividad, o porque cuando actuaba lo hacía sin título ejerciendo como administrador con el consentimiento de la sociedad.

Para los casos particulares de algunas irregularidades en su situación jurídica, su identificación no reviste especial dificultad, sobre todo en el caso particular de las personas que actúan con un título nulo o extinguido. La razón de la fácil identificación de estos administradores de hecho resultará del trazado que comporta su actuación, pues desde que operó su nombramiento continúan en el desempeño de sus funciones, aunque su designación dimane de un acuerdo inválido o un cargo caducado ${ }^{120}$.

${ }^{119}$ Véase LATORRE CHINER, N., "El concepto de administrador de hecho", cit., p. 853.

${ }^{120}$ Como acertadamente clasifica estos tipos de administradores de hecho DÍAZ ECHEGARAY, J. L., Deberes y responsabilidad, cit., 2004, pp. 225-226; DÍAZ ECHEGARAY, J. L., "El administrador de hecho", cit., pp. 128-133; PERDICES HUETOS, A., "Significado actual de los administradores de hecho", cit., pp. 282. 
Entre las diversas manifestaciones que ofrece el primero se encuentra aquel administrador de hecho que actúa dentro de la sociedad en virtud de una designación que todavía no se encuentra inscrita en el Registro Mercantil. Otra manifestación de este tipo de administrador de hecho es el administrador que ha sido nombrado con la inobservancia de formalidades, ya sea por deliberación inválida o ineficaz, o cuando su nombramiento derivó de la vulneración de las normas en el procedimiento para su designación, $v$. gr., si no se observaron las normas para la convocatoria de la junta y, en este, caso el nombramiento sería susceptible de nulidad, o si en el administrador recae prohibiciones para serlo (véase el supuesto de un nombramiento a un sujeto que no reúne mayoría de edad y que no había sido emancipado ${ }^{121}$. También podemos encontrar una más de sus posibles manifestaciones cuando existe una falta la aceptación del cargo por el administrador, o cuando cesado prosigue con el ejercicio de la actividad de administración y continúa ejerciendo las funciones de administrador.

Sin embargo, donde sí que persiste la dificultad es respecto a los administradores que actúan con el consentimiento tácito de la sociedad o sin haber aceptado el cargo. El problema se plantea cuando una persona actúa y la sociedad admite su actuación sin nombramiento y, en este caso, el remedio que acuña la doctrina sería el de acudir a los actos de la junta que toleran la actuación realizada por este sujeto bajo la justificación de que la sociedad no la ha revocado, por ejemplo, aquel que presenta las cuentas anuales para que sean aprobadas y la junta las aprueba sin manifestar oposición alguna. Otra manifestación de este tipo de administrador notorio es aquel que se presenta en una sociedad integrada por un solo socio, $v$. $g r$. la sociedad unipersonal, y también entre las sociedades que se integran un mismo grupo si los administradores de las dominadas aceptan las directrices impartidas por las dominantes, aunque este supuesto también podría incardinarse para la manifestación de un tipo de administrador de hecho oculto.

${ }^{121}$ Explicando el nombramiento irregular del administrador o la separación, su dimisión y caducidad del cargo y a pesar de estas circunstancias el administrador sigue ejerciendo las funciones de administrador con su calificación de administrador de hecho, véanse DÍAZ ECHEGARAY, J. L., "El administrador de hecho", cit., pp. 117-125; LATORRE CHINER, N., "El concepto de administrador de hecho", cit., pp. 877-88. 


\subsection{Administrador de hecho oculto bajo cualquier título}

Siguiendo el trazado que se ha acogido en la definición de administrador de hecho, nos encontramos con el tipo administrador de hecho en su manifestación oculta bajo el amparo de cualquier título; en particular, nos referimos al factor o gerente o a otros altos cargos con facultades de alta dirección. Esta manifestación la encontramos en las personas que ostentan un teórico apoderamiento y utilizan estos poderes huyendo de los consejos de administración, pero dedicándose a la función directiva como funciones de administración que van más allá de las actividades que comprenden las facultades que normalmente se otorgan a un alto ejecutivo $^{122}$.

\subsection{Administrador de hecho oculto propiamente dicho}

La segunda manifestación del administrador de hecho oculto la encontramos en aquel sujeto que no se manifiesta externamente, ni dentro ni fuera de la sociedad, pues su objetivo es precisamente actuar en la sombra desde fuera de la sociedad o incluso dentro de la sociedad, pero ocultando siempre su actuación. La manifestación de este especial administrador de hecho oculto resultará difícil, precisamente por su manera de actuar, que será impartiendo instrucciones a los administradores que sistemáticamente cumplen las órdenes del verdadero administrador que de hecho viene dirigiendo la sociedad. Hay que advertir ${ }^{123}$ que este tipo de administrador de hecho oculto se puede presentar con una variedad de combinaciones, lo que nos va a resultar una tarea muy difícil de identificar, aunque sí podríamos señalar como típica manifestación la del socio único o la de los socios mayoritarios que se inmiscuyen en la gestión de la sociedad, sobre todo, en las grandes SA, conocidos como accionistas de control ${ }^{124}$, aunque esta modalidad suscita una gran incertidumbre en la práctica societaria ${ }^{125}$.

${ }^{122}$ Un análisis muy detallado de los diferentes aspectos del administrador oculto bajo el título de apoderado, véase RODRÍGUEZ DÍAZ, I., "El administrador oculto", cit., pp. 36 -38.

${ }^{123}$ En este sentido, véase RODRÍGUEZ DÍAZ, I., “E1 administrador oculto”, cit., pp. 35-39.

${ }^{124}$ En torno al administrador de hecho y el socio mayoritario, véase RODRÍGUEZ SÁNCHEZ, S., "La responsabilidad del administrador de hecho", cit., pp. 112-113.

125 En eta línea, véase CID BLASCO, T., Y GARCÍA BIGUAZZI, T., "El régimen de responsabilidad de los administradores", en AA.VV., La reforma de la Ley de sociedades de capital en materia de gobierno corporativo, cit., pp. 71-79. 
Otras manifestaciones pueden ser los contratos de distribución, de concesión y franquicia, en los que se produce una traslación de los poderes de gestión a favor de otros órganos extra institucionales. Este tipo de administrador de hecho también se puede manifestar cuando las entidades bancarias conceden préstamos a la sociedad insolvente e imparten instrucciones a los administradores, indicando en este caso cómo debería ser el curso de los préstamos que han sido concedidos, y de esta forma oculta administran a estas sociedades insolventes ${ }^{126}$.

Dentro de este tipo de administradores de hecho oculto nos encontramos, por su especial relevancia, con aquel que actúa mediante el concurso de un testaferro, hombres de paja normalmente insolvente, denominados una "legión de insolventes" que, aunque investido como administrador social, sigue al pie de la letra sus instrucciones amparándose para actuar bajo cualquier título societario o bajo la cobertura de un socio mayoritario ${ }^{127}$ con el fin de conseguir un único propósito, que los pilares sobre los que se asienta la responsabilidad de los administradores se derrumben para que resulte ineficaz debido a que el administrador formal es insolvente ${ }^{128}$. Al respecto, nuestra jurisprudencia ha venido sosteniendo en SSTS de 24 de septiembre de 2001 (RJ 7489/2001) y de 24 de noviembre de 2005 (RJ 7854/2005) que, una vez descubierto quién es el verdadero administrador de hecho, se debería absolver a los administradores nombrados ficticiamente y condenar al verdadero administrador de hecho, que es aquel que se esconde tras este hombre de paja o testaferro ${ }^{129}$.

${ }^{126}$ En torno al administrador de hecho y los acreedores de la sociedad, véase BRENES CORTÉS, J., "La responsabilidad del representante persona física del administrador persona jurídica", en AA.VV., Estudio sobre la responsabilidad de los administradores, cit., pp. 80-121.

127 Véase GARCÍA-CRUCES GONZÁLEZ, J. A., Administradores sociales y administrador de hecho, cit., pp. 527 y ss.

${ }^{128}$ Para un análisis detallado de los distintos tipos de administradores de hecho, véase PRADES CUTILLAS, D., "Administradores de hecho: tipologías no tan encubiertas", La Ley, 6 de mayo de 2009, pp. 5-11.

${ }^{129}$ Reflejando el socio único como verdadero administrador de hecho, véanse SSTS de 24 de septiembre de 2001 (RJ 7489/2001); de 24 de noviembre de 2205 (RJ 7854/2005) o aquel caso del nombramiento como administrador de una persona de nacionalidad cubana que era vigilante de seguridad de la nave de la sociedad que se encontraba cerradas y se razonaba la exclusión de su responsabilidad, amén de que solo había ocupado el cargo de administrador quince días y también porque tampoco puede admitirse que $\mathrm{D}$. Roberto conociera o pudiera razonablemente conocer la concurrencia de causa de disolución a la vista de las especiales circunstancias que confluyen en este supuesto que son que el anterior administrador y socio único de la empresa contacta con un vigilante jurado nocturno de las instalaciones de la sociedad al que se le ofrece, a cambio de una recompensa económica, el cargo de administrador, sin que aquel tuviera la menor vinculación con la empresa, ni formación para el cargo, ni menos aún conocimiento de sus funciones y competencias como administrador. 
Otra manifestación que puede alcanzar al administrador de hecho oculto es aquella que aparece cuando en la institución de los grupos, la sociedad dominante con sus acuerdos influye en el órgano de administración de la dominada y de forma sistemática acepta las instrucciones que dimanan de la sociedad matriz; no obstante, esta posible figura del administrador de hecho en su manifestación oculta será objeto de un mayor estudio en epígrafes infra ${ }^{130}$.

También podríamos encontrar otra manifestación más en aquellas personas que se encuentran vinculadas a los administradores formales de la sociedad, es decir, los familiares, cónyuge, hijos o cualquier parentesco de afinidad. No obstante, todas estas figuras como manifestaciones del administrador de hecho oculto también serán objeto de mayor estudio cuando abordemos cada una de ellas en epígrafes infra.

En síntesis, la opción legislativa rechaza las reglas de la formalidad para que el administrador de hecho sea destinatario de los presupuestos de la responsabilidad de los administradores, pues, fue la funcionalidad la que influyó en la definición legal para que pudiera englobarse a un mayor número de personas ${ }^{131}$. Sin embargo, el legislador debería haber optado por una definición más restrictiva en aras a la seguridad jurídica, pues con esta definición se puede calificar a cualquier sujeto como administrador de hecho si ejerce funciones propias de los administradores ${ }^{132}$.

\section{Criterios identificativos del perfil funcional de los administradores de hecho}

\subsection{Planteamiento}

El problema fundamental que presenta el administrador de hecho lo encontramos en la definición del art. 236.3 LSC al disponer de una forma genérica que, para adquirir esta condición jurídica deberá aparecer una conducta que se corresponda con el ejercicio efectivo

\footnotetext{
42.

${ }^{130}$ En esta línea de desarrollo, véase RODRÍGUEZ DÍAZ, I., "El administrador oculto”, cit., pp. 40-

${ }^{131}$ En este sentido restrictivo del concepto de administrador de hecho, véase LATORRE CHINER, N., "El concepto de administrador", cit., p. 864 y ss.

${ }^{132}$ En este sentido EMBID IRUJO, J. M, “Todos son (y serán) administradores”, cit., p. 1-3.
} 
de las funciones que son propias del órgano de administración en el tráfico mercantil. De ahí que, para identificar al administrador de hecho, primero, se nos plantea una cuestión: ¿cómo podemos descubrirlo? Ante este interrogante solo tenemos una respuesta: que lo descubriremos con su conducta en un contexto social determinado ${ }^{133}$.

El art. 236.3 LSC contempla la definición de administrador de hecho, aunque no regula sus pautas de actuación, limitándose a señalar que es el que actúa ejerciendo las funciones propias de los administradores. Con estos antecedentes para poder identificar a un administrador de hecho por su modo de actuar en cualquiera de sus manifestaciones, debemos recurrir a los criterios doctrinales que han perfilado sus pautas concretas de actuación con el fin de poder evitar una aplicación indiscriminada de la responsabilidad de los administradores a las personas que simplemente han interferido en algunas funciones del administrador ${ }^{134}$. De ahí que, a los efectos de poder clarificar si una persona merece la calificación jurídica de administrador de hecho debamos acudir a los criterios que se comprenden en la llamada “teoría del administrador de hecho”, que es la que se configuró con base en que este solo sería aquella persona que, sin ostentar un título valido, venía desempeñando labores de gestión y de representación en la sociedad siempre que actuara de forma independiente y con una habitualidad en los actos de gestión, y que vendría a identificarse como el administrador de hecho notorio ${ }^{135}$. Así, "el administrador de hecho notorio es aquel sujeto que careciendo de nombramiento regular ejerce actividad de gestión igual o, al menos equiparable a la del administrador, de una forma directa, continuada y sin oposición de la sociedad formalmente constituida". Esto es, quien no tiene un nombramiento vigente necesitará, además, que sus funciones de administración hayan sido realizadas de una forma sostenida ${ }^{136}$.

En paralelo, también la jurisprudencia ha venido sosteniendo, en SSTS de 20 de julio de 2010 (RJ 6563/2010) y de 4 de diciembre de 2012 (RJ 2405/2012), que el administrador de hecho era aquel sujeto que, de forma reiterada y continuada, actuaba como verdadero gestor

${ }^{133}$ En este sentido, estableciendo esta consideración DÍAZ ECHAGARAY, J. L., El administrador de hecho, cit., pp. 135-138.

${ }^{134}$ Haciendo estas advertencias, SANCHO GARGALLO, I. "La extensión subjetiva del régimen de responsabilidad de los administradores de hecho y ocultos", cit., pp. 618-621.

${ }^{135}$ En esta línea explicando las pautas de actuación de un administrador de hecho LATORRE CHINER, N., "El concepto de administrador de hecho", cit., pp. 869.

136 Describiendo como deben ser las pautas de actuación del administrador de hecho, véase LATORRE CHINER, N., "El concepto de administrador de hecho", cit., p. 860-866. 
social realizando una actuación que no implicara subordinación alguna al órgano de administración cuando adoptaba sus decisiones de administración ${ }^{137}$.

De ahí, que para poder concluir en qué supuestos concretos nos encontramos ante un administrador de hecho en una sociedad, hay que analizar los criterios que doctrina y jurisprudencia han venido elaborando ${ }^{138}$. Los requisitos recogidos por la doctrina ${ }^{139}$ se construían por la concurrencia de una serie de notas en la actuación del sujeto y que seguidamente enunciaremos de forma sucinta, debido a que serán objeto de un estudio más profundo en epígrafes siguientes.

El primer requisito consistía en una actuación realizada de forma habitual y con continuidad en el tiempo, permanente para la sociedad y con un verdadero protagonismo en los actos de dirección. El segundo requisito, que las decisiones de carácter administrativo deberían ser adoptadas por estos sujetos con plena autonomía y de manera reiterada sobre las decisiones que conciernen al objeto social, y que se refieren a la ejecución de las actividades que son las propias de la marcha de la sociedad.

\subsection{Criterios de identificación de la actuación de un administrador de hecho}

Vamos a poner de relieve los criterios consolidados que determinan las pautas de actuación del administrador de hecho dentro del contexto de aquellas sociedades que vienen administrando, y que son tanto de índole cuantitativa como cualitativa, con el objetivo de alcanzar un mínimo de seguridad en su identificación. El conjunto de las pautas de actuación o notas esenciales que deben concurrir en la conducta de un administrador de hecho son las siguientes: Primera, el administrador de hecho deberá ejercer las labores de administración. Segunda, presencia efectiva, permanente y real en la gestión social y con verdadero protagonismo, hasta tal punto que se pueda deducir, en todo momento, que esa persona

${ }^{137}$ En este sentido, véanse, entre otras SSTS de 20 de julio de 2010 (RJ 6563/2010); de 4 de diciembre de 2012 (RJ 2405/2012).

138 Ver por todos, GARCÍA-CRUCES GONZÁLEZ, J. A., Administradores sociales y administradores de hecho, cit., p. 8.

${ }^{139}$ Con mayor detalle, sobre estos requisitos, véanse LATORRE CHINER, N., "El administrador de hecho", cit., pp. 865-870; FUENTES NAHARRO, N., "Una aproximación al concepto de administrador de hecho", cit., pp. 289-310; RODRÍGUEZ DÍAZ, I., "El administrador oculto", cit., pp. 32-35. 
ostenta todas las facultades de decisión en la sociedad. Tercera, un poder que sea autónomo, que implique que la decisión se adoptó con total independencia sin subordinación alguna del órgano de administración, es decir, que tenga un poder soberano en el destino de la sociedad. Y cuarta, que los actos sean de dirección con un ejercicio sistemático y continuado de las labores de administración.

Por último, las actuaciones concretas del administrador de hecho culminarán con el conocimiento tácito de la sociedad concretado en la aceptación por parte de los socios de la actuación realizada por el sujeto. Es decir, que debe existir una actuación directa y efectiva de dirección o gestión sobre materias que son reservadas a los administradores y que esa actuación haya sido consentida por parte de la sociedad ${ }^{140}$.

Llegados a este punto tendremos que analizar dos premisas que sirven para detectar su actuación. La primera, observar los actos que ha ido realizado la persona en las relaciones internas o externas de la sociedad, y la segunda, un juicio de valor por el que se concluye que los actos se corresponden con un verdadero administrador de hecho y, a partir de ahí, podremos deducir que la persona viene actuando en la sociedad merece la calificación de administrador de hecho.

\subsubsection{Actividad positiva de gestión o administración}

La actuación principal ejercida por un administrador de hecho es la que tendrá que ver con las actividades que desempeñe, que serán actuaciones específicas de gestión ${ }^{141}$ y que supongan un ejercicio positivo y efectivo de gestión que solo se origina con una participación activa en la administración societaria, porque presupone que a quien se pretende atribuir esta condición ha venido desarrollando actividades que corresponden a la dirección administrativa de la sociedad.

${ }^{140}$ Para mayor estudio estas premisas HERNÁNDEZ MARTÍNEZ, W. D., "Los supuestos de aplicación del administrador de hecho: un análisis del caso español a propósito de la sociedad por acciones simplificada", en Estudio Socio-Jurídico, Bogotá, Colombia, 2012.

${ }^{141}$ Explicando estas notas características de la actuación de un administrador de hecho, véase SANCHO GARGALLO, I., "La extensión subjetiva del régimen de responsabilidad a los administradores de hecho y ocultos", cit., pp. 618-621. 
La concreción de esta nota esencial se manifiesta con el ejercicio real, positivo y efectivo de la gestión empresarial y, sobre todo, en las materias que corresponden al ámbito de las competencias del órgano de administración, es decir, que la actividad realizada por el administrador de hecho no se corresponda a meras actuaciones $\mathrm{u}$ omisiones en la administración. No obstante, en esta sede podrían admitirse actos de omisión como pauta de una actuación del administrador de hecho, en concreto, en la omisión de los deberes legales. Sin embargo, la responsabilidad solo sería exigible al administrador de hecho en la medida en que pudo realizar su cumplimento. No obstante, este punto concreto será objeto de un estudio más profundo en el capítulo tercero ${ }^{142}$.

La razón de que la actividad positiva constituya una nota esencial en las pautas de actuación del administrador de hecho radica en la constatación de un hecho, ya que el administrador de hecho no dimana del nombramiento, sino más bien del hecho que se construye sobre la constancia de un ejercicio positivo en funciones de administración o gestión en la sociedad, incluso cuando concierta negocios jurídicos representando a la sociedad con terceros ${ }^{143}$.

La demostración de este requisito, ya sea con una actividad externa en materias propias de administración ya sea como en asuntos internos, se dará cuando los actos no se limiten a meros consejos o recomendaciones sobre el desarrollo de las actividades de los administradores ${ }^{144}$. En este sentido, la doctrina jurisprudencial en SSTS de 4 de marzo de 2007 (RJ 261/2007); de 14 de marzo de 2007 (RJ 1793/2007); de 8 de febrero de 2008 (RJ 2664/2008); de 4 de febrero de 2009 (RJ 1364/2009) y de 14 de abril de 2009 (RJ 2897/2009), incluyó esta nota para poder clarificar esta figura, y con tal propósito definía la figura del administrador de hecho como, "quienes, sin ostentar formalmente el nombramiento de administrador y demás requisitos legales exigibles ejercen la función como si estuviesen legitimados, prescindiendo de tales formalidades como gestores de estos, pues, la característica del administrador de hecho, no es la realización material de determinadas

${ }^{142}$ En torno a esta nota en la actuación del administrador de hecho GARCÍA-CRUCES GONZÁLEZ, J. A., "Administradores sociales y administrador de hecho", cit., pp. 8-15; GARCÍACRUCES GONZÁLEZ, J. A., "Administradores sociales y administradores de hecho", cit., pp. 527561.

${ }^{143}$ En torno a estas manifestaciones ARROYO MARTÍNEZ, I., “Artículo 133”, cit., pp. 1415-1416.

${ }^{144}$ En este sentido DÍAZ ECHEGARAY, J. L., El administrador de hecho, cit., p. 38. 
funciones, sino la actuación en la condición de administrar con inobservancia de las formalidades mínimas, que la ley o los estatutos exigen para adquirir tal condición” ${ }^{145}$.

Por consiguiente, para que una actuación pueda corresponderse con la realizada por el administrador de hecho se necesitará la concurrencia del ejercicio efectivo de las funciones propias del órgano de administración sin sujeción a otras directrices que no sean las propias del administrador de hecho, v. gr., cuando el administrador de hecho ha ejecutado como administrador societario los acuerdos que han sido adoptados por la Junta general o las actividades relativas a actos de administración esenciales, como la convocatoria de la junta general, la redacción de las cuentas anuales, el control y la llevanza de la contabilidad, la convocatoria de la junta general para poder disolver cuanto se originan perdidas cualificadas, o la puesta en conocimiento de la situación de insolvencia a los socios.

También pueden señalarse aquellas labores específicas de los administradores, como los informes en operaciones del aumento de capital, las modificaciones estructurales conversión de obligaciones en acciones etc. Es decir, cuando un sujeto se sitúa en una posición superior realizando una planificación empresarial en la sociedad de forma continuada con la aquiescencia del órgano de administración y consentimiento de la sociedad. No obstante, debemos advertir que bajo la apariencia de ciertos cargos directivos no tiene por qué ocultarse un administrador de hecho, a pesar de que realizaran funciones gestoras.

\subsubsection{Actuación permanente de dirección de la sociedad}

La segunda nota que caracteriza las pautas de actuación de un administrador de hecho es el ejercicio de actividades que deberán tener una intensidad cuantitativa que se traduzca en actividades reiteradas y con una cierta permanencia, es decir, que no se limiten a meros consejos aislados, sugerencias o recomendaciones o a alguna incidencia en la gestión de la sociedad, sino que más bien signifiquen un trazado directo y continuo del ejercicio de actividades de gestión.

${ }^{145}$ Véanse SSTS de 4 de marzo de 2007 (RJ 261/2007); de 14 de marzo de 2007 (RJ 1793/2007); de 8 de febrero de 2008 (RJ 2664/2008); de 4 de febrero de 2009 (RJ 1364/2009); de 14 de abril de 2009 (RJ 2897/2009). 
En esta misma línea, la doctrina jurisprudencial siempre ha venido exigiendo, según SSTS de 22 de julio de 2015 (RJ 2512/2015); y de 8 de abril de 2016 (RJ 1323/2016), que la condición jurídica de administrador de hecho solo se alcanza cuando la actuación se ejerza con una intensidad cuantitativa que obedezca a una serie de actos reiterados que demuestren la intervención del administrador de hecho en la gestión, hasta tal punto que llegue a sustituir al administrador de derecho ${ }^{146}$. De lo expuesto anteriormente se podría deducir que quedarían excluidas las intervenciones puntuales, aunque tengan carácter de verdaderos actos de administración, pues solo se puede detectar la presencia del administrador de hecho cuando realizó notoriamente las funciones de administración de forma habitual y permanente.

Por consiguiente, vamos a descartar las actuaciones que no serían suficientes para ser calificadas como actuaciones de un administrador de hecho, entre ellas señalamos las simples sugerencias o la supervisión que desarrolla un socio mayoritario cuando se limita a controlar a los administradores, las recomendaciones que realiza una entidad de crédito cuando solo se limita a supervisar cómo se viene aplicando el crédito que concedió a la sociedad, o las instrucciones que derivan de un contrato de franquicia cuando el franquiciador se limita a supervisar y controlar el cumplimiento de las obligaciones del franquiciado ${ }^{147}$.

No obstante, se ha puesto en duda que esta nota se considere esencial para poder adquirir la condición jurídica de administrador de hecho, sobre todo en el ámbito del derecho concursal, ya que un sujeto podría ser así calificado por no haber realizado una actuación puntual o aislada en la gestión de la sociedad con base en que la continuidad en la actuación habría que entenderla como una mera posibilidad ${ }^{148}$. En concreto, su responsabilidad podría

${ }^{146}$ En este sentido, SSTS de 22 de julio de 2015 (RJ 2512/2015); de 8 de abril de 2016 (RJ 1323/2016) donde se perfila que en la actuación del administrador de hecho debe concurrir el ejercicio de funciones propias de los administradores de forma constante y DÍAZ MORENO, A., "Observaciones sobre administradores acuerdos de refinanciación, "Fresh Money" y subordinación", en AA.VV., Estudio sobre la responsabilidad de los administradores, cit., pp. 53-76.

147 Ver por todos, en este sentido MERCADAL VIDAL, F., "El acreedor financiero como administrador de hecho. Especial referencia a los covenants", ADConc, núm. 36, pp. 115-128; NIETO DELGADO, C., "¿Puede la banca ser calificada como administrador de hecho tras una refinanciación?”, ADConc, núm. 40, 2017, pp. 179-196.

${ }^{148}$ En el mismo sentido restringido ABRIANI, N., "Gli administratoria di fatto delle società di capital", cit., pp. 1-3; ABRIANI, N., "Riforma del diritto societario e responsabilità dell amministratore di facto: verso una nacione unitaria dell institutte", Revista La società, núm. 2, 2000, p. 216; BARTALINI, G., La responsabilità degli amministratori e de directore generali di società per azioni, Turín, 2000, p. 309. En contra, GARCÍA-CRUCES GONZALEZ, J. A., La calificación del concurso, Ed. Aranzadi, Pamplona, 2004, p. 157 y ss.; SANTOS BRIZ, J., "La responsabilidad fiscal 
derivar, simplemente, de una decisión o de la omisión de un deber legal que perjudique a la sociedad o a terceros, $v$. $g r$., aquel sujeto que realizó una actividad como si fuera un administrador y posteriormente omite la obligación legal de solicitar el concurso, y en consecuencia participó en el origen o en el agravamiento de la insolvencia, ya que conociendo esta situación omitió el deber de solicitar el concurso de la sociedad.

Por su parte, los que sostienen esta tesis consideran que, si bien la permanencia en el poder de decisión es elemento probatorio para la calificación de un administrador de hecho, no debería de dejarse a un lado el ejercicio de una actuación concreta o la omisión de un acto que, por no haberse realizado, perjudicó a la sociedad. El ejemplo paradigmático lo encontramos cuando el administrador de hecho ante la insolvencia omitió la obligación de convocar la junta general para lograr el acuerdo de disolución, y a causa de esta omisión los acreedores se ven privados de satisfacer sus créditos contra la sociedad ${ }^{149}$.

Sin embargo, y a pesar de estas apreciaciones, mantenemos que la actuación del administrador de hecho debe ser realizada de una forma permanente por la persona que merecería tal calificación, pues este es uno de los requisitos más relevantes, por no decir es el más destacado, debido a que la jurisprudencia lo ha considerado como uno de los requisitos imprescindibles para poder identificarlo ${ }^{150}$.

\subsubsection{Ejercicio de las funciones con total independencia}

La tercera nota característica en la actuación de un administrador de hecho viene caracterizada por un ejercicio que debe de responder a un poder de decisión autónomo e independiente, es decir, aquella actuación que se manifestará con una imposición de

civil penal de los directivos apoderado. Administradores de hecho y liquidadores de las sociedades de capital”, en AA.VV., La responsabilidad de los administradores de las sociedades de capital, Ed. Estudios de Derecho Judicial Consejo General del Poder Judicial y Consejo General del Notariado), Madrid, 2000, pp. 327-352.

149 Nuevamente hacemos referencia sobre esta consideración en la doctrina, véase GARCÍACRUCES GONZÁLEZ, J. A., Administradores sociales y administrador de hecho, cit., p. 11.

${ }^{150}$ Explicando esta consideración, véase SANCHO GARGALLO, I., "La extensión subjetiva del régimen de la responsabilidad", cit., p. 620. 
decisiones que tengan una influencia decisiva para el destino de la sociedad y que podrá ser realizado directa ${ }^{151} \mathrm{o}$ indirectamente, pero con el consentimiento de la sociedad ${ }^{152}$.

Este requisito constituye una nota implícita para la actuación de esta figura, pues se necesitará que la persona adopte sus decisiones con plena autonomía, sustituyendo a los administradores, pero nunca de forma subordinada con un poder soberano que implique imponer sus propias decisiones en la conducción del objeto social, es decir, que no se podrá calificar una actuación de dirección con autonomía cuando una persona siga las instrucciones de los administradores que han sido designados por la sociedad ${ }^{153}$.

No obstante, podría ocurrir que una persona, presentándose bajo la apariencia de sujeción a una relación laboral, se encontrase realizando labores de gestión, y también adquiera la condición de administrador de hecho si se demostrase la falsedad de la subordinación laboral. Es decir, podría merecer la condición de administrador de hecho aquel sujeto que disponga de amplios poderes que le permitan actuar con libertad de decisión en las transacciones de la sociedad con terceros, independientemente de su relación laboral con la sociedad. Sin embargo, para clarificar esta situación debemos acudir a la nota que caracteriza al administrador de hecho: que la imposición de decisiones influya de forma determinante sobre toda la administración de la sociedad y de este modo se tenga la certeza de cuándo verdaderamente nos encontramos ante un administrador de hecho, o que simplemente estemos ante un apoderado que con amplias facultades actúa de forma permanente realizando las funciones de administración aunque sin llegar a ejercitar el verdadero poder autónomo de decisión en la sociedad ${ }^{154}$.

En definitiva, para que una actuación se pueda considerar como ejercida por un administrador de hecho se necesitarán dos requisitos. El primero, que el sujeto realice una

${ }^{151}$ Sobre esta nota que caracterizan la actuación de un administrador de hecho, véase JUSTE MENCÍA, J., "En torno, a la aplicación del régimen de responsabilidad de los administradores al apoderado general de la sociedad", cit., p. 425.

${ }^{152} \mathrm{Al}$ respecto, la doctrina considera que no surtirá efecto la oposición singular de un socio hasta que no se traduzca en un acuerdo aprobado por la junta, en este sentido PERDICES HUETOS, A., "Significado actual de los administradores de hecho", cit., p, 182.

153 Véase DÍAZ ECHEGARAY, J, L., El administrador de hecho, cit., p. 42.

${ }^{154}$ El elemento de un poder autónomo en la actuación del administrador de hecho, véase SANCHO GARGALLO, I., "La extensión subjetiva de la responsabilidad", cit., pp. 620-621. 
actuación autónoma y de dirección que implique el desarrollo de la actividad empresarial con pleno poder soberano y sin subordinación alguna a las instrucciones de un tercero. Y, el segundo, que las actuaciones deberán ser actos enmarcados en la política empresarial, independientemente de que el sujeto actúe de forma directa o indirecta; es decir, ya sea de forma oculta bajo la apariencia de cualquier cargo societario, ya sea de otra forma impulsando y dirigiendo a quien formalmente representa a la sociedad, que de forma sistemática viene ejecutando las decisiones del aquel sujeto que ordena el destino financiero y económico de la sociedad en la sombra.

\subsubsection{Conocimiento y consentimiento de la sociedad}

El conocimiento de la sociedad acerca de las actuaciones que realiza el administrador de hecho es un elemento indispensable para su identificación, y suele manifestarse cuando la sociedad acepta tácitamente el negocio jurídico o la vinculación generada cuando se relaciona en el ámbito externo con terceros ajenos a la sociedad. También se constatará cuando la sociedad obedezca y cumpla cada uno de los actos que el sujeto realizó en el ámbito interno de la sociedad. El consentimiento de la sociedad se presumirá por la falta de oposición.

Este requisito se exigía por la antigua teoría formalista para calificar al administrador de hecho, pues la posición de éste y la aquiescencia o tolerancia de los socios que representen la mayoría del capital es lo que permite deducir que los actos son realizados por un administrador de hecho ${ }^{155}$.

Sin embargo, se suscita la duda de hasta donde la tolerancia por parte de la sociedad podría implicar que la actuación ejercida por una persona podría corresponder a un administrador de hecho. La cuestión planteada obedecía al supuesto de que una mera actuación realizada por alguien se podía traducir en un mero aprovechamiento por la sociedad y, en este caso particular, no se podría identificar a la persona que realizó el acto como administrador de hecho. De ahí, que el alcance del consentimiento tácito de la sociedad en la consideración del administrador de hecho solo se puede demostrar, por ejemplo, si la sociedad

${ }^{155}$ Explicando el requisito tácito del consentimiento de la sociedad, véase PERDICES HUETOS, A., "Significado actual de los administradores de hecho", cit., pp. 281-282. 
se aplicara automáticamente el resultado de su actuación repartiendo los beneficios obtenidos sin efectuar protesta alguna.

Por otro lado, también podríamos apreciar el consentimiento de la sociedad cuando la junta no se cuestiona las actuaciones de aquel sujeto. Debemos resaltar que tampoco el consentimiento tácito se desvirtuaría si algún socio se opone de forma expresa y, a pesar de esta oposición, el sujeto continúa realizando sus tareas de administración. En este caso, sería imprescindible que la oposición formulada se transformara en un acuerdo adoptado por la junta general para que el sujeto no fuera calificado como administrador de hecho. Esta consideración se complementa con la culpa in vigilando por parte del órgano de administración que no obstaculizó, en ningún momento, las actuaciones de aquel sujeto que realizó las labores administrativas sin nombramiento por la sociedad.

\section{EL ADMINISTRADOR OCULTO Y SU ESPECIAL CONSIDERACIÓN COMO ADMINISTRADOR DE HECHO}

\section{Antecedentes}

El primer reflejo del administrador oculto en nuestro sistema societario llegó con el ya mencionado Informe Aldama, el cual sugería que se extendieran los deberes de lealtad a aquella persona bajo cuyas instrucciones suelen actuar los administradores de la sociedad. En concreto, esta extensión se justificaba así: “....incluso que la propia regla ordinaria referida a los administradores, pues la mayor opacidad de la actividad de estas personas, que a menudo actúan en la sombra o detrás de los órganos de decisión formales, determina una menor eficacia disciplinar de los instrumentos dispuestos por las fuerzas del mercado". No obstante, el Informe Aldama no enmarcó al administrador oculto como un tipo de administrador de hecho, aunque si expresaba claramente la extensión subjetiva de los deberes de lealtad. También el CUBG de 2006 proponía extenderle tanto el deber de diligencia y el de lealtad como la responsabilidad de los administradores ${ }^{156}$.

\footnotetext{
${ }^{156}$ Véase la recomendación complementaria 6.b del Código Unificado de Buen Gobierno de 2006.
} 
Desde el punto de vista legislativo el art. 133.2 TRLSA omitió mencionarlo cuando reconoció, o más bien describió, al administrador de hecho. No obstante, este tipo de administrador de hecho se utilizaba en el juego societario con frecuencia para eludir la responsabilidad de los administradores.

Pese a este panorama legislativo, se sostenía que podría interpretarse de forma amplia la definición, ya que sería un sinsentido obviar a los que administraban impartiendo instrucciones vinculando a los administradores formales ${ }^{157}$. Resultaba una cuestión doctrinal controvertida pues, por una parte, un sector doctrinal sostenía que el autor inductor merecería la misma consideración que el administrador de hecho, ya que por su manera de actuar se le podría exigir responsabilidad cuando, de manera oculta, incumpliera los deberes inherentes al cargo de administrador societario ${ }^{158}$. Y, por otra parte, se entendió como un instrumento que servía para implementar una política más severa en materia de deslealtad, pudiendo extenderse la responsabilidad de los administradores a aquellos que en la trastienda administraban ${ }^{159}$.

Hay que señalar que la doctrina ${ }^{160}$ y la jurisprudencia, en SSAP de Valencia de 27 de septiembre de 1999 (RJ 289/1998) y de Madrid 26 de noviembre de 2010 (RJ 146/2010 ${ }^{161}$, ya distinguían entre dos tipos diferentes de administradores de hecho, y también en STS de 24 de septiembre de 2001(RJ 7489/2001) ${ }^{162}$. Por un lado, quienes estando en primera línea ejecutiva disponían de una elevada autonomía de decisión y administraban a la sociedad a

157 Véase PAZ-ARES RODRÍGUEZ, C., "La responsabilidad de los administradores como instrumento de gobierno corporativo", cit., p. 17.

${ }^{158}$ En este sentido, véase DÍAZ ECHEGARAY, J. L., El administrador de hecho, cit., pp. 47-48.

159 Véase PAZ-ARES RODRÍGUEZ, C., Y VELASCO CABALLERO, F., Infracciones administrativas y auto cartera, Ed. McGraw Hill, Madrid, 1997, p. 34.

${ }^{160}$ En esta corriente, véanse ALFARO AGUILA-REAL, J., "Sobre administradores de hecho y subordinación de créditos ex arts. 92 y 93 LC", htto://unirioja.es, Madrid, 19 de abril de 2012; PAZARES RODRÍGUEZ, C., "La responsabilidad de los administradores como instrumento de gobierno corporativo", cit., pp. 17 y ss.; PERDICES HUETOS, A., "Significado actual de los administradores de hecho", cit., pp. 277-287, donde se explica el régimen de responsabilidad del administrador oculto como un administrador de derecho.

${ }^{161}$ En este sentido la jurisprudencia confirmaba la calificación como de administradores de hecho ocultos a las personas que manejaban efectivamente la sociedad con actos concretos como dar órdenes a los empleados, contratar proveedores o disponer de fondos sociales., véanse SSAP de Valencia de 27 de septiembre de 1999 (RJ 289/1998) y de Madrid 26 de noviembre de 2010 (RJ 146/2010).

162 Véase STS de 24 de septiembre de 2001(RJ 7489/2001). 
cara descubierta y, por otro, los administradores ocultos. Este calificativo se atribuiría a los administradores que, sin ocupar formalmente el cargo, venían controlando de facto la gestión con una influencia decisiva, y que incluso llegarían a sustituir a los administradores de derecho, aunque sin aparecer como administrador de hecho ante terceros ${ }^{163}$.

Así pues, las diferencias entre el administrador de hecho y el oculto se basaron en que el primero actuaba de forma externa, mientras que el segundo siempre actuaba sin manifestación exterior. El administrador de hecho ejercía una dirección directa equivalente al administrador formal, mientras que el oculto ejercía una dirección indirecta a través de intermediarios que, normalmente, eran los administradores ${ }^{164}$. No obstante, la primera definición de esta figura la podemos encontrar en el Derecho inglés en 1985, que acuñó el término de "Shadow director" o administrador en la sombra, eminencia gris", "administrador oculto" o "administrador indirecto"” 165 .

${ }^{163}$ Un análisis detallado de estas diferencias, véanse DÍAZ ECHEGARAY, J. L., El administrador de hecho, cit., pp. 46 y ss.; JUSTE MENCÍA, J., "En torno a la aplicación del régimen de responsabilidad de los administradores al apoderado genera", cit., pp. 446 y ss.; MARTÍNEZ SANZ, F., "Los administradores responsables", en AA.VV., La responsabilidad de los administradores de las sociedades mercantiles (Dir. ROJO FERNÁNDEZ-RÍO Y BELTRÁN SÁNCHEZ), Ed. Tirant lo Blanch, Valencia, 2013, pp. 55-81.; OLIVARES JAMES, J.M., "En torno a los administradores de hecho en la SA", cit., pp. 272 y ss.; PERDICES HUETOS, A., "Significado actual de los administradores de hecho", cit., pp. 277 y ss.

${ }^{164}$ Caso Hydrodan (Corby) Limited, se distingue entre los directores de iure, de facto y los "Shadow" estableciendo que estos dos últimos términos no se superponen, sino que son alternativos, e incluso, la mayor parte de las veces, excluyentes. En el caso citado, sostiene el juez que para calificar a alguien de director de hecho es necesario probar que ha ejercido las funciones propias de un director. Sin embargo, para considerar a alguien como "administrador en la sombra" se han de probar los siguientes extremos: en primer lugar, quiénes son los directores de la compañía, tanto los de hecho como los de derecho; en segundo lugar, el hecho de que el administrador indirecto es el que determina la actuación de los directores de la sociedad indicándoles las formas de proceder; y, finalmente, que tales directores (de hecho o de derecho) no solo actúan de acuerdo con las instrucciones recibidas en un momento determinado sino que están habituados a obrar de tal manera. En este último aspecto es donde la jurisprudencia pone especial énfasis, por cuanto significa que los administradores han renunciado a la tarea de tomar sus propias decisiones, optando, en lugar de ello, por seguir las instrucciones de un tercero que actuaba con una intención consciente de controlar la actividad del órgano de administración". Véanse, los comentarios al caso BRATTACHARYYA, G., "ReHydrodan Corby Ltd-shadow director and wronful trading", Com. L., mayo 1994, p. 151 y ss.; CAMPBELL, N. R., "Liability as Shadow Director". Jrnal. B. L, 1994, pp. 609 y ss.

${ }^{165}$ En 1985 (Companies Act, sec. 741) "Shadow director, jeans a person in accordance with whose directions the directors of the company are accustomed o act. However, a person in not deemed a shadow director by reason only that directors act on advice given by him in a professional capacity". En este sentido, en el 251 de la Act, se dice "es administrador en la sombra una persona cuyas directivas e instrucciones están acostumbrados a actuar los administradores de la sociedad", véanse DÍAZ ECHEGARAY, J. L., El administrador de hecho, cit., pp. 110-111. FELIÚ REY, J. Y RODRÍGUEZ DE LAS HERAS BALLELL, T., "La proyectada reforma del derecho de sociedades en el Reino Unido: Companies Bill", cit., pp. 25-33. 
El administrador oculto solo se reconocería si se demostraban otras circunstancias. En primer lugar, que dirigiera a los administradores de la sociedad y, en segundo lugar, que estos actuaran según sus instrucciones. En cambio, la jurisprudencia inglesa era partidaria de una interpretación restrictiva sosteniendo que no nacería cuando los administradores habían actuado siguiendo, simplemente, algún consejo profesional por una persona en un determinado momento ${ }^{166}$. De este modo no consideraba a las entidades financieras que se implicaban en la gestión de la sociedad deudora como shadow director ${ }^{167}$.

En esta línea, otros ordenamientos jurídicos como el francés, en el art. 245.16 del Código de Commerce, incorporaban una referencia genérica en materia de responsabilidad sobre el administrador de hecho en aquellas disposiciones que afectaban al presidente y a los administradores, a los directores generales e, incluso, a los gerentes de sociedades. Así, consideraban que las responsabilidades de los administradores debían de aplicarse a aquellas personas que, directamente o por persona interpuesta, hubieran ejercido de hecho actos de dirección o administración en las sociedades bajo la cobertura de sus representantes legales ${ }^{168}$. La legislación francesa fue más allá porque extendió la responsabilidad de los administradores a los ocultos, inclusive en el ámbito penal, pues en el art. 431 de la Ley de Sociedades Comerciales se perseguía a los administradores de hecho ${ }^{169}$.

${ }^{166}$ A propósito de la posibilidad de considerar que una entidad de crédito intervenga de forma activa en la gestión de una empresa durante un cierto tiempo se apunta que tal circunstancia no ha llegado a aplicarse en la práctica anglosajona, dada la prudencia de los Bancos para no intervenir así en las sociedades en crisis. También, es muy restrictivo admitir que en España se pueda considerar administradores de hecho oculto a las entidades financieras por el hecho de refinanciar a empresas en crisis cuando determinan obligaciones de hacer o no hacer, o por constituir comités de crisis como el caso, de la crisis inmobiliaria de 2007 cuando prestaron financiación a grandes empresas inmobiliarias a cambio de la toma de medidas de control de gestión duras en la sociedad ya que la doctrina es partidaria de una actuación directa en la administración con ejercicio reiterado y sistemático en la gestión, véase PULGAR EZQUERRA, J., La responsabilidad de las entidades financieras por concesión abusiva de crédito en derecho español, tendencias actuales en torno al mercado de crédito, Ed. Marcial Pons, Madrid, Barcelona, Buenos Aires, 2010, pp. 141-149.

${ }^{167}$ Véase la interpretación restrictiva de la jurisprudencia inglesa en torno a la consideración de los bancos como administrador oculto, RODRÍGUEZ DÍAZ, I., "El administrador oculto", cit., pp. 26-27.

${ }^{168}$ Explicando el administrador de hecho Derecho Francés, véase RIBELLES ARELLANO, J. M., Y GIMÉNEZ RAMÓN, R., "El administrador de hecho", en Órganos de la sociedad de capital, Ed. Tirant lo Blanch, Madrid, 2008, pp. 657-659.

169 En el Derecho español algunos autores han abogado por esta tesis, véanse GARCÍA DE ENTERRÍA, J., Los delitos societarios: en su enfoque mercantil, Ed. Cívitas, Madrid, 1996, pp. 45 y ss.; FERNÁNDEZ DE LA GÁNDARA Y SÁNCHEZ ÁLVAREZ, Ma., "Los delitos societarios, reflexiones preliminares sobre la imposición de acuerdos sociales abusivos", AJA, núm. 238, 1996, pp. 1 y ss. Y con perspectiva penal MAGRO SERVET, V., "Persecución penal de los ilícitos cometidos por los administradores de hecho", La Ley, núm. 6541, 4 de septiembre de 2006, pp. 1-7. 
Por su parte, el ordenamiento jurídico alemán se pronunció a favor del administrador oculto y lo incluyó en el ámbito de aplicación de responsabilidad de los administradores; en concreto, cuando una persona ejercía su influencia en el poder de decisión de la dirección o en el Consejo de Vigilancia de la sociedad ${ }^{170}$.

Por otro lado, la doctrina italiana equiparó la figura del administrador oculto con la figura del "socio tirano" definiéndolo como aquel sujeto que ostentaba el dominio de la sociedad abusando de su posición y violaba las reglas de organización interna de la sociedad induciendo a los administradores en su propio provecho ${ }^{171}$.

En resumen, teniendo en cuenta las anteriores consideraciones podríamos afirmar que la diferencia entre el administrador de hecho y el oculto reside en que, el primero era el que asumiría tan solo funciones desarrolladas por los administradores, mientras que el segundo aparecerá cuando concurran determinadas circunstancias. En concreto, deduciríamos, primero, que debían existir los administradores de derecho; segundo, que el administrador oculto debería indicar a los de derecho cómo debían de actuar; tercero, que los administradores formales siguieran todas sus instrucciones; y cuarto, que el oculto debería desarrollar las actividades normales de los administradores societarios.

Es importante destacar que nuestra doctrina distinguió dos tipos de administradores ocultos. El primero, aquel que actuaba "ad extra" bajo otra apariencia, es decir, con otra forma que a la luz de la experiencia jurisprudencial se verificaba entre los parientes de los administradores, en sociedades familiares o bajo la apariencia de un apoderado o factor. El segundo, más complejo, aquel que ejercía en la sombra una influencia sobre los administradores de la sociedad ${ }^{172}$.

${ }^{170}$ Véase el art. 117 de la Ley de sociedades anónimas (“Aktiengesetz") alemana "quién utilizando su influencia sobre la sociedad incite dolosamente a un miembro de la Dirección o del Consejo de Vigilancia, a un apoderado general o a un apoderado especial, a actuar en perjuicio de la sociedad o sus accionistas, estará obligado frente a la sociedad a indemnizar los daños producidos".

${ }^{171}$ En este sentido, véanse BIGIAVI, C. W., "Responsabilità ilimitata del socio tiranno", in Foro Italiano, 1960, I,c, pp. 1180 y ss.; CAPONI, R., "Socio predominante e rischico di empresa", Rivista Diritto Commerciale, TI, 1989, pp. 381 y ss.; RAGUSA MAGGIORE, G., "Socio tiranno, azionista único e perssitenza della personalitá giuridica", Diritto Famillantere Commerciale, 1977, pp. 651 y ss.

${ }^{172}$ En este sentido estableciendo la diferencia entre los dos tipos de administradores de hecho ocultos, véase PERDICES HUETOS, A., "Significado actual de los administradores de hecho", cit., pp. 285 - 286. 
Por último, anticipar que, en nuestro país, como veremos tras la reforma de la Ley 31/2014 de la LSC, se diferenció entre el administrador de hecho en sentido estricto y el oculto $^{173}$.

\section{El administrador oculto: un tipo legal de administrador de hecho}

\subsection{Delimitación previa}

El art. 236.3 LSC no solo contempla a los administradores de hecho propiamente dichos, que son aquellos sujetos sin título, con un título nulo o extinguido, o con otro título, sino que también describe a aquel que realiza funciones de administración impartiendo instrucciones a los administradores formales de la sociedad. En concreto, señala que, "tendrá la consideración de administrador de hecho la persona que en la realidad del tráfico desempeñe las funciones propias de administrador, como, en su caso, aquel bajo cuyas instrucciones actúen los administradores de la sociedad". Se produce con ello una extensión subjetiva de la responsabilidad al administrador de hecho oculto. Así pues, en este epígrafe resultará necesario afrontar la problemática de una de las modalidades más difíciles del administrador de hecho: su manifestación oculta.

La razón de esta problemática reside en la amplitud de supuestos que pueden englobarse en este tipo de administrador en la práctica societaria; a lo que se añade una mayor complejidad para identificarlo por su forma de actuar ocultamente. Su reconocimiento, no obstante, significa un avance para lograr la armonía societaria en el sistema jurídico español. Aun así, siguen subsistiendo interrogantes claves como ¿quién es la persona física o jurídica que imparte instrucciones a los administradores de la sociedad? o ¿por qué los administradores cumplen sus instrucciones sistemáticamente? ${ }^{174}$.

173 Estableciendo esta distinción tal y como viene establecido en la Ley 3172014, véase RODRÍGUEZ DE LAS HERAS BALLELL, T., "Requisitos para ser administrador", cit., pp. 750-752.

174 Estableciendo estas interrogantes, véanse GARCÍA DE ENTERRÍA, J., "Los deberes de conducta de los administradores", cit., p. 75; RODRÍGUEZ, DÍAZ, I., "El administrador oculto", cit., pp. $42-54$. 
En este trabajo trataremos de arrojar alguna luz sobre los posibles perfiles del administrador de hecho oculto estudiando sus distintas manifestaciones, aunque advertimos que se trata de una cuestión muy controvertida tanto en nuestra doctrina como en la comparada. Al efecto, se ha intentado delimitarlo sosteniendo que dentro de ella se enmarcan aquellas personas que inducen a los administradores a dirigir la sociedad impartiendo directrices de cierta duración que materialmente estos ejecutan. No obstante, el administrador de hecho oculto es el que alberga una mayor dificultad para su identificación, porque puede presentarse con los perfiles de algunos cargos societarios o bajo cualquier forma para poder llevar a cabo su actuación, y porque puede confundirse con otras figuras societarias que solo ejercitan su cargo según su propia naturaleza.

Por tanto, la única forma de identificar a este tipo tan especial de administrador de hecho se encuentra en su propia esencia, que reside en que actúa absolutamente en la sombra utilizando a los administradores de derecho que actúan bajo su dictado. Consecuentemente, la dificultad radica en demostrar el ejercicio efectivo del cargo de administrador. Esta demostración no resultara tarea fácil, precisamente porque lo que caracteriza a este administrador de hecho es su actuación en la sombra.

\subsection{Concepto de administrador de hecho oculto}

El legislador calificó al administrador de hecho oculto en el art. 236.3 LSC recurriendo simplemente a un concepto indeterminado, pues solo dispuso que es aquella persona que con meras instrucciones induce a los administradores a actuar en la sociedad. En atención a este concepto indeterminado cualquier tipo de influencia no sería suficiente para poder ser calificada como la realizada por un administrador de hecho oculto. Por tal motivo, se ha sostenido que para detectar su presencia se necesitaría que esta influencia fuese de una intensidad cualitativa y de carácter decisivo sobre la voluntad de los administradores formales. Será, por tanto, una cuestión muy relativa precisar qué influencia se considera tan decisiva para que los administradores actúen de acuerdo con la decisión impartida. Por esta razón, la determinación de una actuación de un administrador de hecho oculto deberíamos identificarla a la vista de supuestos concretos y, a su vez, analizando las relaciones que unen al extraneus administrador de hecho oculto con el formal. 
De ahí que, prioritariamente, deberemos constatar que los administradores actúan bajo las órdenes del oculto como meros testaferros u hombres de paja $\mathrm{y}$, posteriormente, observar si las actuaciones que vienen realizando se corresponden con las órdenes dictadas por aquel. A estos efectos, deberán concurrir una serie de requisitos esenciales ${ }^{175}$ : El primero, que el administrador formal responda a las órdenes de forma sistemática. El segundo, que la influencia del administrador oculto sea decisiva en los asuntos de administración que impliquen una comunicación entre la influencia y las consecuencias que se deriven de sus directrices. El tercero, que el administrador formal no adopte decisiones propias. Por último, que su influencia pueda demostrase de forma objetiva. Es decir, que bastará la demostración de un número de directrices para concluir que los administradores formales abandonaron la dirección de la sociedad.

En resumen, el requisito esencial para que una actuación merezca la calificación de haber sido realizada por un administrador de hecho oculto es que se trate de una dirección efectiva en la administración, y que las instrucciones de dirección sean impartidas permanente y sistemáticamente para realizar las tareas de dirección, las cuales serán obedecidas y aceptadas por los administradores sin discusión alguna. Así pues, el administrador de hecho oculto, tal y como se configura en el art. 236.3 LSC, tiene como característica esencial que dirige y gestiona la sociedad con las instrucciones que los administradores ejecutan sistemáticamente.

Por ello, consideramos que solo podría darse la calificación jurídica de administrador de hecho a los administradores de hecho ocultos. Así, con el apoyo de nuestra doctrina defendemos que los administradores de hecho ocultos, aunque solo actúan en la sombra, controlan la gestión social porque ejercen sobre los administradores formales una influencia decisiva que, incluso, puede llegar a sustituirles con instrucciones cuando los administradores las aceptan para negociar con terceros. Por el contrario, el administrador de hecho notorio, o el oculto que actúa bajo la apariencia de otro título como apoderado, se limita simplemente a entrometerse en la esfera que comprende la competencia de los administradores, ya sea

${ }^{175}$ Un análisis detallado de la conducta del administrador de hecho oculto, véase RODRÍGUEZ DÍAZ, I, "El administrador oculto", cit., pp. 16 y ss. 
porque ostenta amplias facultades, porque actúa con un cargo inválido o ineficaz, o porque actúa bajo otra figura societaria ${ }^{176}$.

\section{Perfiles de administrador de hecho oculto: supuestos controvertidos generalmente excluidos}

El ejemplo paradigmático del administrador oculto es el socio mayoritario, que como un soberano influye en los administradores gestionando la sociedad. Sin embargo, también se atribuye esta condición a otros supuestos ${ }^{177}$. Citaremos, a título de ejemplo, los siguientes:

Primero, el director general o gerente cuando actúa emitiendo órdenes a los administradores formales que "están acostumbrados a obedecer" y, en este caso, nos encontraríamos con aquel tipo de administrador de hecho oculto que actúa como administrador bajo la apariencia de otro título o cargo societario.

Segundo, el representante voluntario o falso procurador cuando se presenta un sujeto dotado de un poder general que le facilitará el revestimiento adecuado para actuar gracias a las facultades que ostenta. Actúa como administrador bajo la apariencia de un título.

Tercero, el sujeto que con apariencia de un simple apoderado influye y dirige a los administradores formales, es decir, actúa también bajo un título.

Cuarto, las entidades acreedoras de empresas cuando los acreedores dirigen la sociedad impartiendo instrucciones a los administradores en una situación de dificultad económica ${ }^{178}$.

${ }^{176}$ En torno a estas connotaciones del administrador de hecho oculto, véase HERNANDO CEBRIÁ, L, "Presupuestos del deber de lealtad: artículo 227.1", en AA.VV., Régimen de deberes, cit., pp. 152153.

${ }^{177}$ En este sentido, véanse DÍAZ ECHEGARAY, J. L., El administrador de hecho, cit., pp. 78-81; LEFÉVRE, F., Administradores y directivos, Dossier Práctico, Ed. Francis Lefévre, Madrid, 20142015, pp. 182-184; RODRÍGUEZ DÍAZ, I, “El administrador oculto”, cit., pp. 35-36.

${ }^{178}$ En el caso de acreedores tiranos se consideró que no daban instrucciones, sino que se trataba de rescatar a la sociedad de aquello a los que tenían derecho como acreedores, véase REPFTZM, Ltd., BCLC 354, BCC, 1995, p. 280. 
Quinto, entidades de crédito y financiación cuando emiten préstamos a la sociedad en situación de insolvencia; y para velar por el destino de los fondos concedidos dirigen la sociedad con órdenes decisivas ${ }^{179}$.

Sexto, cuando en un contrato de suministro de materia prima para la sociedad, la entidad suministradora de la materia emite órdenes a los administradores que aceptan con sumisión expresa.

Séptimo, la empresa de consultoría cuando implanta sus directrices a los administradores dibujando planes de viabilidad a la sociedad ${ }^{180}$.

Octavo, los grupos de sociedades cuando su filial se encuentra sometida al mandato de la matriz ${ }^{181}$.

Noveno, las personas vinculadas a los administradores por lazos familiares $\mathrm{y}$, sobre todo, en el caso concreto de la llamada empresa familiar. En este supuesto podremos detectar la presencia del administrador de hecho oculto en función de las relaciones de parentesco entre el administrador y sus personas afines, padres, hijos, hermanos, esposo o esposa y familia en general, siempre que influyan en los administradores ${ }^{182}$.

En esta línea de desarrollo la doctrina jurisprudencial ha realizado una auténtica labor de investigación para poder detectar a este tipo administrador oculto que es tan especial, concluyendo que no puede apoyarse en meras recomendaciones o simples consejos hacia los

${ }^{179} \mathrm{Si}$ bien con respectos a estos la experiencia inglesa no parece estar convencida, véase FARRAR, S., Company Low, Ed. $4^{\text {a }}$, London. 1998, p. 337 y pp. 573-574.

${ }^{180}$ Admitiendo a los acreedores y a los prestadores de servicios como administradores de hecho ocultos, ALFARO AGUILA-REAL, J. Y GARCÍA MARTÍN, F., "Sobre administradores de hecho y subordinación de créditos ex arts. 92 y 93 LC", cit., p. 1.

${ }^{181} \mathrm{El}$ administrador de la sociedad dominante que administra la dominada bien sea de forma directa, impartiendo instrucciones para los administradores de la dominada o bien de forma indirecta, cuando deciden sobre asuntos de la dominada en asuntos de administración, ha de ser administrador de hecho de dicha sociedad, en este sentido SÁNCHEZ ÁLVAREZ, A., "Grupos de sociedades y responsabilidad de los administradores", $R D M$, núm. 227, 1998, pp. 117 y ss.

182 Sobre las personas vinculadas al administrador de la sociedad, RAMOS HERRANZ, I., "Prohibición de utilizar el nombre de la sociedad y la condición de administrador para influir indebidamente en operaciones privadas por cuenta propia o realizadas por personas vinculadas (artículo 229.1 b) de la Ley de Sociedades de Capital”, en AA.VV., Gobierno Corporativo, cit., pp. 465-507. 
administradores de la sociedad ${ }^{183}$; y con base en este argumento se logró excluir, con carácter general, a determinadas personas o cargos societarios del ámbito de la actuación del administrador de hecho oculto, sin perjuicio del concreto caso enjuiciado. De este modo, los supuestos que alguna vez se han considerado, pero que se han excluido como administrador de hecho oculto, son los que seguidamente pasamos a detallar ${ }^{184}$.

En primer lugar, se excluyó el supuesto de contratos celebrados entre la sociedad y los prestadores de servicios o de consultoría cuando el objeto del contrato implicaba que algunas personas tuvieran la obligación de supervisar el desarrollo de las funciones de gestión para su mejora. Para esta exclusión se apoyaron en la falta de relación, directa o indirecta, entre los administradores y las personas que intervienen en el contrato de prestación de servicios con la sociedad. Otra cuestión sería que el contrato de servicios dimanara de una sociedad creada $a d$ hoc con un órgano de administración que resultase integrado por las personas que prestan los servicios y que son las mismas que integran el órgano de administración que se encuentra prestando los servicios objeto del contrato ${ }^{185}$.

De igual forma, se excluyó al administrador insolvente, porque si bien podría entenderse que detrás de un insolvente siempre se debería esconder un administrador de hecho oculto que actúa en la sociedad mediante el concurso de una persona interpuesta, sin embargo, este apriorismo es erróneo ya que tendría que existir una realidad oculta para llegar a tal consideración.

También, se excluyó a los apoderados, fundamentalmente con base en la premisa de que los apoderados solo actúan por un mandato y sin autonomía, por su condición de

${ }^{183}$ En este sentido, SSTS de 26 de mayo de 1998 (RJ 4004/1998) y de 7 de junio de 1999 (RJ 509/1999). de 22 de marzo de 2004 (RJ 1661/2004) en las que para considerar a un administrador de hecho es necesario que se demuestre que estos realicen las funciones de un efectivo administrador y estableciendo los requisitos de habitualidad, permanencia y continuidad en el ejercicio de funciones y la exigencia de los elementos de autonomía o falta de subordinación como elemento definitorio de un administrador de hecho, SAP de Barcelona de 24 de enero de 2005 (RJ 118837/2005) y sentencia del Juzgado de lo mercantil núm. 1 de Cantabria de 18 de octubre de 2006 (RJ 175/2006).

${ }^{184}$ Véase esta exclusión de la consideración de administrador oculto, SANCHO GARGALLO, I., "La extensión subjetiva del régimen de la responsabilidad", cit., p. 620.

${ }^{185}$ Solo se le aplicaría la consideración de administrador de hecho cuando la prestación de servicios consiste en servicio de administración, véase RODRÍGUEZ DÍAZ, I, "El administrador oculto", cit., p. 338. 
subordinados, aunque realicen funciones de administración, y porque sus actuaciones son puntuales interviniendo en las fases previas a las decisiones de los administradores ${ }^{186}$.

En esta misma línea se considera excluido de la condición de administrador de hecho oculto al socio mayoritario cuando solo ejerce su derecho de control sobre los administradores, o la entidad de crédito que supervisa cómo la sociedad está empleando el dinero prestado, o el caso del franquiciador que, simplemente, se limita a controlar al franquiciado sobre la base del contrato de franquicia.

Por último, nos encontramos con los grupos de sociedades que, desde el punto de vista de nuestra doctrina, se han venido considerando excluidos como administrador de hecho oculto, ya que la sociedad matriz no realiza actividades de administración en las filiales de forma oculta, sino que más bien solo realiza una actividad de cabeza del grupo que implica una gestión externa de dirección del grupo y conocida por todos ${ }^{187}$.

\section{LAS MANIFESTACIONES CONCRETAS DEL ADMINISTRADOR DE HECHO}

Como ya hemos indicado, la teoría del administrador de hecho se utilizó para poder extender la responsabilidad de los administradores a personas físicas o jurídicas, aunque en sentido restrictivo, porque apariencia y realidad normalmente coinciden ${ }^{188}$. Por su parte, la LSC presenta un abanico de sujetos como administradores de hecho en el art. 236.3, donde solo tiene en cuenta la fase ejecutiva, es decir, su forma de actuar, prescindiendo de reglas formales para poder calificarle.

Por tanto, es evidente que la condición de administrador de hecho deberá recaer sobre aquellos sujetos que ejercen funciones efectivas de administración bajo dos formas de

\footnotetext{
${ }^{186}$ No cabría la consideración de un apoderado como administrador de hecho por su relación de subordinación y dependencia, véase RODRÍGUEZ DÍAZ, I, "El administrador oculto”, cit., pp. 336338.

${ }^{187}$ Explicando estos argumentos, véanse SANCHO GARGALLO, I., "La extensión subjetiva del régimen de la responsabilidad", cit., p. 620 y SÁNCHEZ CALERO, F., Los administradores, cit., p. 316.

${ }^{188}$ Resaltando el carácter represivo de la disciplina del administrador de hecho, véase LATORRE CHINER, N., "El concepto de administrador de hecho", cit., p. 884.
} 
actuación. La primera, sustituyendo a los administradores de la sociedad y, la segunda, actuando con una influencia decisiva sobre estos, impartiendo directrices que comprendan la dirección completa de la sociedad. No obstante, dada la amplia definición legal, cualquier persona que ejerza gestión o representación en la sociedad podrá alcanzar tal consideración. Nuestro objetivo consistirá en un estudio pormenorizado de las posibles manifestaciones que presenta la definición para impedir que se pueda producir una situación indiscriminada. Esta labor se intentará realizar en aras a conseguir mayor seguridad jurídica, con el apoyo de criterios doctrinales para discernir si existe administrador de hecho o no en la sociedad, ya que no se puede generalizar la idea de que cuando un sujeto realice funciones de gestión se convierta automáticamente en administrador de hecho.

\section{El administrador de hecho notorio}

El administrador de hecho se ha venido identificando tradicionalmente con el ejemplo paradigmático del administrador notorio. Este es aquel que había sido nombrado por la sociedad como tal, pero su título presentaba algún vicio en su nombramiento, o estaba caducado o cesado, aunque todos presentaban como nota común que continuaban realizando sus funciones de administración y representación ${ }^{189}$. También se engloba en este supuesto aquella persona que se encontraba administrando sin título, aunque ejercía con nombramiento implícito, pues la sociedad consentía que este sujeto ejerciera como si fuera el administrador ${ }^{190}$.

Aquí surge de nuevo la postura defendida por la doctrina formalista partidaria de que en el concepto de administrador de hecho solo se podían englobar los sujetos en los que existía un nombramiento previo de la sociedad, identificándolo con la nomenclatura de administrador de hecho notorio, con la apariencia de que era el administrador que venía administrando la sociedad ${ }^{191}$. Siguiendo esta línea, el art. 236.3 LSC acogió el carácter

189 Sobre la responsabilidad del administrador con el cargo caducado, véase. GARCÍA DE ENTERRIA, J., "Los pactos de indemnización del administrador cesado", RDM, 1995, pp. 473 y ss.

${ }^{190}$ Según la doctrina formalista se englobaba en esta categoría del administrador de hecho sin título y también al administrador de hecho con un nombramiento implícito, véanse DÍAZ ECHEGARAY, J. L., El administrador de hecho, cit., p. 129; MINERVINI, G., Gli administratori, cit., pp. 128-133.

${ }^{191}$ Definiendo al administrador de hecho notorio, véase PERDICES HUETOS, A., "Significado actual de los administradores de hecho", cit., p. 281. 
sustancial de la actuación, es decir, si venía realizando injerencias en las competencias atribuidas a los administradores. Por esta razón, debemos analizar aquellos perfiles de administrador de hecho que ejercen las funciones propias del cargo de administrador sin un título válido.

En relación con el administrador de hecho que resulta de un nombramiento inválido debemos clarificar que dentro de este perfil nos encontramos con varias situaciones ${ }^{192}$. La primera, es la que contempla a un administrador de hecho cuando la junta no se pudo constituir en debida forma para su nombramiento o cuando un administrador inicia sus funciones sin nombramiento $\mathrm{y}$, más tarde, la sociedad le designa. Sin embargo, un nombramiento inválido, por sí solo, no implicará que automáticamente el sujeto se convierta en administrador de hecho. Así, para poder merecer tal condición debe atenderse a su actuación con título invalido, y tendríamos un indicio para considerarlo como tal.

Por otro lado, nos encontramos con el tipo de administrador de hecho cesado que continúa realizando las funciones de administrador, y con el administrador de hecho con título caducado. Estas son situaciones frecuentes en la práctica societaria para que la sociedad no se paralice y continúe funcionando hasta que se designe nuevo administrador ${ }^{193}$. Los administradores con el cargo caducado y los cesados adquirirían automáticamente la calificación de administradores de hecho si continúan ejerciendo las funciones propias del cargo por dos motivos fundamentales. El primero, por el conocido principio de buena fe registral que protege a los terceros que, de buena fe, verifican que el administrador se encuentra inscrito en el Registro Mercantil y, en definitiva, ignoran si ha sido cesado o que su cargo estaba caducado. El segundo, es consecuencia del primero, porque el nombramiento del administrador continúa inscrito en el Registro Mercantil, aunque el administrador cesado o con el cargo caducado prosigue ejerciendo las funciones de administración.

En cambio, el criterio unánime que se ha venido sosteniendo por parte de nuestra doctrina y jurisprudencia es que no operaría ninguna equiparación automática con el

${ }^{192}$ Estableciendo esta distinción, véase DÍAZ ECHEGARAY, J. L., El administrador de hecho, cit., pp. 117-120.

${ }^{193}$ En este sentido sobre la inscripción del cargo, véase FRANQUET, J. F., "La ausencia de inscripción en el Registro del cese de los administradores y el problema de su responsabilidad", Boletín del Centro de estudios Registrales de Cataluña, núm. 87, 2000, p. 329. 
administrador de hecho, porque lo que determina el cese de un administrador es el cese efectivo más que la inscripción de ese cese en el Registro Mercantil ${ }^{194}$. También se ha sostenido que podría considerarse administrador de hecho cuando el administrador cesado continúa con el ejercicio permanente de las tareas del cargo de administración a pesar de estar inscrito su cese en el Registro Mercantil ${ }^{195}$. De modo que el administrador cesado es un administrador de hecho si continúa con el ejercicio de administrador que, por otra parte, es el criterio que se reflejó en el art. 236.3 LSC cuando menciona como posibles administradores de hecho a aquellos sujetos con un título caducado si desempeñen las funciones propias del cargo de administrador en el tráfico mercanti1 ${ }^{196}$.

Por su parte, el art. 236.3 LSC establece otro perfil de administrador de hecho sin título, que es aquel que ejerce las funciones propias de administración con el consentimiento implícito por parte de la sociedad. Es el administrador designado sin la aceptación del cargo que, como es bien sabido, por el propio concepto de órgano se traduce en la distinción entre el órgano de administración y los titulares de ese órgano y, por esta razón, los administradores tienen que aceptar el cargo para poder administrar ${ }^{197}$. Las razones anteriormente expuestas derivan, como todos podemos deducir, de que lo que se indica en el art. 214 LSC, cuando establece que el nacimiento del administrador se produce si la junta nombra a una determinada persona, esta acepta el cargo y se inscribe en el Registro Mercantil ${ }^{198}$, a excepción de que se nombrara en el momento de la fundación de la sociedad. En ese caso, como se dispone en el art. 22.1.e) LSC, los fundadores son los que nombran a los administradores en la escritura fundacional ${ }^{199}$. Y, por otro lado, en el art. 214.3 LSC se añade

${ }^{194}$ En esta línea, véase STS de 23 de diciembre de 2002 (RJ 1698/2002).

${ }^{195}$ Estableciendo este criterio sin perjuicio de que el administrador cesado pruebe que él no tuvo relación alguna con el acto que causo el daño MARTínEZ SANZ, F., "Ámbito subjetivo de responsabilidad", cit., p. 79.

196 En este sentido PARDO PARDO, J. M ${ }^{\mathrm{a}}$., El nuevo régimen de responsabilidad de los administradores de empresas en crisis, Ed. Bosch, Barcelona, 2015, pp. 257-260.

197 En este sentido, véase la doctrina de la teoría orgánica sobre la concepción de órgano distinguiendo entre el órgano de administración y las personas titulares del órgano que son los administradores DÍAZ ECHEGARAY, J. L., Deberes y responsabilidad, cit., pp. 67-73.

${ }^{198}$ En el art. 124.2 del Registro Mercantil se establece que, en los estatutos se hará constar también a qué tipo de administradores se confiere el poder de representación, así como su régimen de actuación.

199 Para mayor estudio, GALLEGO SÁNCHEZ, E., "Los administradores", en AA.VV., Comentarios de la Ley de Sociedades de Capital (Dir. BELTRÁN SÁNCHCEZ Y ROJO FERNÁNDEZ-RÍO), Ed. Cívitas, Madrid, 2011, pp. 1502-1552. 
que la condición de administrador surtirá sus efectos desde la aceptación, aunque en el art. 215 LSC se establece que el cargo deberá de inscribirse en el Registro Mercantil salvo el caso de consejeros delegados donde los efectos de su designación solo se producirán cuando el nombramiento y la aceptación se inscriban en el Registro Mercantil. De ahí, que el problema se suscita con respecto al administrador que, nombrado por la sociedad, no llega a aceptar el cargo. Por esta razón, el art. 236.3 LSC calificó como administrador de hecho a la persona con título nulo, que sería aquel sujeto que se presenta con un cargo que no había aceptado y, en cambio, viene ejerciendo funciones de administración ${ }^{200}$. No obstante, no debemos olvidar los efectos declarativos de la inscripción del cargo de administrador, ya que solo se podrán inscribir actos del administrador si el cargo se encuentra inscrito en el Registro Mercantil y, por esta razón de nuevo, se presenta la problemática de cómo se inscribirán los actos realizados por el administrador de hecho cuando por ser de hecho, precisamente, su nombramiento no se haya inscrito en el Registro Mercanti1201.

Hay que advertir que, en todos los casos mencionados podría ocurrir que los administradores de hecho se encuentren unidos al administrador formal, que solo se limita a adoptar una conducta meramente pasiva o simplemente a tener que cumplir con sus instrucciones. Esta situación se traduce en una presencia del administrador de hecho en su manifestación oculta y los actos se inscribirían normalmente porque los realizó el administrador formal de la sociedad con la influencia del administrador oculto, que es la opinión que mantenemos en esta tesis.

\section{El administrador de hecho oculto bajo otra apariencia}

\subsection{El representante aparente}

El representante aparente como administrador de hecho es una de las cuestiones más controvertidas debido a la tradicional problemática de la representación en el Derecho

${ }^{200}$ Para mayor estudio sobre este tipo de administrador de hecho, véase RODRÍGUEZ DE LAS HERAS BALLELL, T., "Requisitos para ser administrador", cit., pp. 735-741.

201 Explicando la inscripción necesaria en el Registro Mercantil, véase VALPUESTA GASTAMINZA, E., Comentarios a la Ley de Sociedades de Capital, Ed. Bosch, Barcelona, 2015, pp. 584-586. 
mercantil. Esta problemática reside en que no existe una clara delimitación entre los supuestos que contempla la representación, pues nos podemos encontrar con apoderados con distintas facultades de representación que presentan en común el hecho de que la sociedad queda obligada según los poderes encomendados ${ }^{202}$.

Entre ellos, pueden citarse el factor o el director general. Estos mismos, no son por sí administradores de hecho, aunque actúen con facultades de representación amplias y desempeñando funciones que se traducen en el gobierno de la sociedad. En esta línea, un representante aparente no merece la calificación de administrador de hecho, pues se limita a representar a la sociedad sin ejercer labores de administración o de dirección en la sociedad que sean esenciales e imprescindibles para que pueda equipararse a este ${ }^{203}$. Por otro lado, la responsabilidad de los administradores no se extenderá a los representantes salvo que estos actuaran frente a terceros realizando las operaciones societarias con total autonomía y sin subordinación al órgano de administración. Solo en este caso se les aplicarían las mismas normas que a los administradores de derecho, entre ellas, las relativas a la responsabilidad ${ }^{204}$, ya que su exclusión podría suponer un trato de favor a esta figura sin base lógica, pues, en todo caso lo que se pretende es el control del ejercicio del poder que se otorgó, con independencia de quien sea el titular formal del órgano de administración ${ }^{205}$.

${ }^{202}$ Todos ellos agrupados bajo la doctrina de la protección de la confianza en los arts. 286 y 292 CCom, según la cual, el hecho de la apariencia ha de imputarse a su representante legal aunque la responsabilidad recaiga sobre el comerciante, el cual no respondería si aquella circunstancia obedece a actuaciones delictivas, como coacciones, amenazas o estafa, y de las cuales haya sido sujeto pasivo, o que el tercero que ha contratado sea de buena fe, esto es, que ignore que la persona que se encuentra al frente del establecimiento no posee autorización del dueño principal. Las SA pueden otorgar poderes para hacerse representar en juntas generales de sus sociedades participadas, y la actuación de los apoderados puede someterse a previa autorización de otros apoderados (éstos últimos como una comisión delegada); también el Consejo puede otorgar apoderamientos, pero haciendo salvedad expresa de que no incluyan facultades indelegables. Al acto realizado por un apoderado, aunque esté dentro del giro o tráfico del negocio encomendado le sería aplicable la interpretación restrictiva del Código Civil art. 1713.2, que así lo exige para practicar operaciones de tipo registral no autorizada o para enajenar inmuebles. De modo que, aunque exista una inicial falta de poder, la ratificación por hechos posteriores de la representación subsana la mencionada falta inicial y acreditan la existencia de ésta.

${ }^{203}$ En este sentido y explicando las diferencias entre representante aparente y administrador de hecho, véase DÍAZ ECHEGARAY, J. L., El administrador de hecho, cit., pp. 44-45.

${ }^{204}$ En torno a la extensión de la responsabilidad, véanse BELTRÁN SÁNCHEZ, E. Y ROJO FERNÁNDEZ-RÍO, A., "La responsabilidad por las deudas sociales de administradores de sociedades anónimas y limitadas incursas en causa de disolución", AC, 1997-III, pp. 62 y ss.; LEFÉBVRE, F., Administradores y directivos, cit., p. 183.

205 En esta línea de desarrollo, véase ALONSO UREBA, A., La responsabilidad de los administradores de una sociedad de capital con situación concursal (el art. 171.3 del anteproyecto de 
En relación con este supuesto nuestra doctrina ya se pronunció cuando el administrador de hecho se reconoció por la Ley de Transparencia, en el art. 133 TRLSA. Así, se advertía que solo quedarían subsumidos en este concepto aquellos casos en los que efectivamente su conducta reuniera las características de esta figura ${ }^{206}$.

En este mismo sentido, la doctrina jurisprudencial no equiparaba automáticamente al representante como administrador de hecho, salvo que se acreditara que concurrían sus notas definitorias $^{207}$. De ahí, que debamos distinguir el contorno propio que engloba la figura del administrador de hecho para que podamos abordar los supuestos en los que el representante pueda traspasar los contornos de la representación y suplantar a los administradores. En este sentido, si nos acercamos a la visión diferenciadora entre el administrador de hecho y el representante aparente podremos observar que todas las facultades del administrador de hecho resultarían diferentes de aquellas facultades que realiza este ${ }^{208}$. Sin embargo, según la SAP de Lleida de 4 de febrero de 1999, cómo en la práctica un socio único o mayoritario, que controlaba plenamente la sociedad, había nombrado a un representante y la realidad demostraba que la sociedad se encontraba sometida al poder del representante porque actuaba realizando el ejercicio permanente de las funciones propias de administrador con un ejercicio continuo y sin subordinación, entonces se podría presuponer que el representante era administrador de hecho ${ }^{209}$.

ley concursal y sus relaciones con las acciones societarias de responsabilidad). Estudios sobre el anteproyecto de ley concursal de 2001, Ed. Dilex, Madrid, 2002, p. 283.

${ }^{206}$ En este sentido, explicando el reconocimiento del administrador de hecho EMBID IRUJO, J. M., "La responsabilidad de los administradores de la sociedad anónima tras la Ley de Transparencia", cit., pp. 2402-2403.

${ }^{207}$ En este sentido, podemos ver que los representantes de un administrador con forma societaria no se ha probado su condición de administrador de hecho, al considerar que ambas categorías no son equivalente, partiendo de que no es posible la equiparación automática entre representante y administrador de hecho, aunque también cabe que un representante persona física adquiera la condición de administrador de hecho por considerar que en el caso concreto concurrían en el las notas caracterizadoras del administrador de hecho, véase JUSTE MENCÍA, J., "En torno a la aplicación del régimen de responsabilidad", cit. pp. 441-445.

${ }^{208}$ Explicando esta visión diferenciadora, véase DÍAZ ECHEGARAY, J. L., El administrador de hecho, cit., p. 44.

${ }^{209}$ En este sentido, la SAP de Lleida de 4 de febrero de 1999 (RJ 282/1999) establece que lo que importa es el desarrollo de la gestión de la sociedad sea quien sea quien la realiza, de modo que el represente puede aparecer como socio mayoritario habiéndose nombrado a si mismo representante para el ejercicio del cargo en otra sociedad o cuando el representante es el socio mayoritario con el $80 \%$ y administrador de otra sociedad y su esposa ostenta el resto del capital de la sociedad administradora y en sentencia del Juzgado de lo Mercantil Barcelona, núm. 10, de 16 de septiembre de 2014 (RJ 556/2014) donde el juzgador examina la condición de D. xxx como administrador de hecho 
Por otro lado, la falta de oposición y consiguiente tolerancia de la actividad positiva de gestión realizada por un representante aparente equivaldría a un administrador de hecho. Cuestión distinta sería aquel extraneus que usurpa las funciones de administración y, además, entabla relaciones con terceros cuando la sociedad es ajena a dicha usurpación; lo que, este caso, nos permitiría poder distinguir entre la figura de un administrador de hecho y el representante ${ }^{210}$.

A sensu contrario, el representante aparente, por su subordinación al órgano de administración, nunca se equipararía a un administrador de hecho porque su actividad no consiste en actividades de gestión. Solo se equipararía si el órgano de administración le hubiera otorgado poderes para desempeñar funciones de los administradores, aunque no hay que olvidar que el representante aparente carece de autonomía y esta carencia le impedirá atribuirle tal condición ${ }^{211}$.

No obstante, se admitiría la atribución de administrador de hecho en determinadas situaciones, v. gr., cuando el representante con amplios poderes aparece en una sociedad unipersonal en la que el socio único era a su vez el administrador único de la sociedad, y en aquel otro supuesto de una sociedad pluripersonal con un socio mayoritario donde este nombraba a un representante aparente; aunque hay que advertir que el administrador de hecho y el representante aparente no son términos equivalentes ya que esta última figura simplemente representa a la sociedad pero no gestiona.

Por tanto, se concluye que siempre hay que distinguir entre administrador de hecho y representante, ya que el primero no se supedita a un apoderamiento previo sino al hecho de que bajo la apariencia de otras funciones ejerce la administración en el ámbito interno sin la obligación de representar a la sociedad, como es el caso del representante aparente.

al ser el representante de la mercantil ITICSA e, indirectamente, de SPANAIR y califica a D. xxx como administrador de hecho.

${ }^{210}$ Explicando esta diferencia, véanse LATORRE CHINER, N., "El concepto de administrador de hecho", cit., p. 868; PERDICES HUETOS, A., "Significado actual de los administradores de hecho", cit., p. 282.

${ }^{211}$ En este sentido, RODRÍGUEZ DÍAZ, I., "El representante del administrador persona jurídica", $R D B B$, núm. 128, 2012, pp. 35-67; RODRÍGUEZ DÍAZ, I., "La responsabilidad del representante del administrador persona jurídica en el concurso culpable", $A D C$, núm. 308, 2013, pp. 139 y ss. 
Sin embargo, nuestros tribunales se han venido inclinando en el sentido de que podríamos encontrarnos con un verdadero administrador de hecho cuando bajo la forma de un mero representante aparente se vienen ejerciendo actuaciones muy determinadas, como, $v . g$., en SSAP de Pontevedra de 2011 (RJ 304/2011); y de Zaragoza, de 26 de junio de 2012 (RJ 393/2012), donde la persona física designada para representar a la sociedad fue considerada como administrador de hecho al suscribir compromisos de pago que son vinculantes para la sociedad $^{212}$.

Se trata, en definitiva, de no ampliar los contornos del representante aparente pues, de lo contrario, nos llevaría incluso a considerar a un capataz de obra, un encargado o a un secretario administrativo como administradores de hecho y, en definitiva, a cualquiera que haya desarrollado actividad gestora en la sociedad o frente a terceros. Por tanto, debemos deslindar entre la figura del administrador de hecho y la del "representante aparente" que solo representa pero que no ejerce funciones de administración, tal y como la doctrina alemana distinguía cuando diferenciaba entre actividades de alta dirección (Oberleitung) de las que consistían en el mero cumplimiento de las actividades de la vida cotidiana de una sociedad ${ }^{213}$.

\subsection{La persona física representante de la persona jurídica administradora}

Un supuesto que merece especial atención es la persona física representante de una persona jurídica administradora cuando el representante ejerce funciones de administrador y no como subordinado de la persona jurídica administradora, sino que viene adoptando

${ }^{212}$ En este sentido SSAP de Pontevedra de 2011 (RJ 304/2011); de Zaragoza, de 26 de junio de 2012 (RJ 393/2012) donde la persona designada como persona física para representar a la sociedad fue considerado administrador de hecho y en otras no es suficiente para adquirir la condición de administrador de hecho tener un poder general o ser socio mayoritario. LATORRE CHINER, N., "Administrador de hecho y apoderado general (Comentario a la STS de 8 de febrero de 2008 (RJ 2664/2008)", $R d S$, núm. 32, 2009, pp. 389-398. En esta sentencia el apoderado se consideró como administrador de hecho porque aceptaba letras de cambio en nombre de la sociedad y el administrador único había fallecido sin haberse nombrado otro administrador.

${ }^{213}$ Véanse FUENTES NAHARRO, M., "Una aproximación al concepto de administrador de hecho y a la funcionalidad de la figura en los grupos de sociedades", cit., pp. 289-310; JUSTE MENCÍA, J., "Limitaciones al poder de representación del factor en el giro o tráfico del establecimiento. Actuación del administrador societario en calidad de factor", en AA.VV., Derecho de Sociedades. Libro homenaje a Fernando Sánchez Calero, Vol. II, Ed. McGraw Hill, Madrid, 2002, pp. 1351 y ss.; SÁNCHEZ CALERO, F., Instituciones de Derecho Mercantil, vol. I. Ed. Aranzadi, Pamplona, 2009, pp. 137 y ss.; SÁNCHEZ CALERO, F., Los Administradores, cit., pp. 46 y ss.; POLO SÁNCHEZ, E., "Los administradores y el consejo de administración", cit., pp. 158 y ss. 
decisiones de forma independiente y sin atenerse a las instrucciones de la administradora ${ }^{214}$. Sin embargo, cuando ocurra esta situación recurrir a la teoría del administrador de hecho no debería significar un remedio que se tradujera en una equiparación automática ${ }^{215}$. El representante no podría equipararse automáticamente al administrador de hecho porque había sido formalmente designado para realizar el ejercicio permanente de las funciones de la persona jurídica administradora y, por tal motivo, debería equipararse automáticamente con un administrador de derecho ${ }^{216}$. No obstante, también podría tratarse de un caso de administrador de hecho oculto si actuaba bajo la apariencia de un mero representante de la persona jurídica administradora ${ }^{217}$.

Hay que advertir que, aunque en un principio la consideración del representante como administrador de hecho fue objeto de crítica, en la actualidad, el art. 236.5 LSC somete al representante a la responsabilidad de los administradores junto con la persona jurídica administradora para cumplir con los deberes de diligencia y de lealtad de los administradores. En definitiva, al representante se le aplicará el mismo régimen de responsabilidad de los administradores, quedando atrás las teorías que le excluían como administrador de hecho.

Ahora bien, todavía nos suscita dudas que este representante de la persona jurídica administradora pueda ser calificado como administrador de hecho cuando actúa de forma autónoma y con autoridad en las decisiones de dirección efectiva en la sociedad, siempre y cuando no se limite a cumplir con las órdenes de la persona jurídica administradora ${ }^{218}$. De ahí que, aunque si bien, tal y como dispone el art. 236.5 LSC, responderá solidariamente con el administrador persona jurídica por el incumplimiento de los deberes, esta circunstancia no deberá implicar su posible condición de administrador de hecho.

214 En este sentido, GARCÍA-GRUCES GONZÁLEZ, J. A., Administradores sociales y administradores de hecho, cit., 549.

${ }^{215}$ En este sentido, EMBID IRUJO, J, M., "La responsabilidad de los administradores de la sociedad anónima tras la Ley de Transparencia”, cit., pp. 2402-2403.

${ }^{216}$ Esta tesis ha sido defendida por RODRÍGUEZ DÍAZ, I., "El representante administrador persona jurídica", cit., pp. 46-47.

217 Véanse BRENES CORTÉS, J., "La responsabilidad del representante persona física del administrador persona jurídica", cit., pp. 112-113; DEL VAL TALENS, P., El administrador persona jurídica en las sociedades de capital, Ed. Marcial Pons, Madrid, 2017, pp. 175-186 y RODRÍGUEZ DÍAZ, I., "El representante del administrador persona jurídica", cit., p. 47.

218 Véase BRENES CORTÉS, J., "La responsabilidad del representante persona física del administrador persona jurídica”, cit., p. 112. 
Sin embargo, consideramos que el representante es administrador respecto a la sociedad administrada con independencia de la relación jurídica que existe entre el representante y la persona jurídica administradora. De esta manera, ya no será necesario demostrar si en su modo de actuar concurren aquellas notas esenciales que caracterizan las pautas de actuación del administrador de hecho ${ }^{219}$.

\subsection{Altos cargos con amplias facultades de dirección}

En este epígrafe vamos a abordar en qué medida los altos cargos que detentan amplias facultades de dirección se podrían integrar en los perfiles descritos del administrador de hecho por el art. 236.3 LSC, pero bajo la advertencia previa de que los altos cargos de dirección con amplias facultades no son, por sí, administradores de hecho ${ }^{220}$.

Si nos acercamos al contexto de las grandes empresas podremos observar cómo las facultades del órgano de administración se han ido desplazando hacia los altos cargos de dirección, aunque a estos sujetos, por sí, no se les pueden atribuir la condición jurídica de administrador. Sin embargo, hay que resaltar que ha sido una realidad empírica que este personal de alta dirección ha venido ostentado amplias facultades de dirección y de representación en las grandes sociedades, ya que en el art. 249.1 LSC se permite que si el órgano de administración adopta forma de consejo pueda delegar sus facultades.

El ejemplo de las diversas nomenclaturas de las figuras que ostentan estos altos cargos de dirección las podemos encontrar en varios preceptos de la LSC: en el art. 181.1 cuando alude a la figura de directores generales, en el art. 282. 2 con relación a los directivos; también cuando el art. 260.8 cuando menciona a los altos directivos e, incluso, al personal de alta dirección por parte del art. 260.9; y, por último, cuando en los arts. 181.1 y 282.2 se acuña la nomenclatura de los gerentes como una figura asimilada al alto directivo. De ahí que el art. 236.4 LSC extienda todos los deberes de los administradores y su régimen de

219 En este sentido SANCHO GARGALLO, I., "La extensión subjetiva de la responsabilidad", cit., pp. 628-629.

${ }^{220}$ Para mayor estudio, véase MARTÍNEZ SANZ, F., "Los administradores responsables", cit., pp. 90 y 94. 
responsabilidad al personal de alta dirección "cualquiera que sea su denominación”, con independencia de que estos pudieran alcanzar la calificación de administradores de hecho.

El motivo que indujo a nuestro legislador a utilizar la expresión "cualquiera que sea su denominación" radica fundamentalmente en la falta de delimitación legal entre las distintas denominaciones de los altos cargos. De esta manera, nuestro sistema societario se encontró con un sinfín de figuras que habían creado equipos directivos que ocupaban los primeros puestos y escapaban de la responsabilidad, porque su actuación se encontraba protegida de la responsabilidad que solo se aplicaba al órgano de administración, y, por esta razón, el art. 236.4 LSC recogió a los más altos cargos de dirección como responsables por el incumplimiento de los deberes de los administradores.

No obstante, hay que resaltar que el citado art. 236.4 establece varias condiciones para que proceda la extensión de la responsabilidad a estos altos cargos de dirección. La primera, que el órgano de administración debe de adoptar la forma de Consejo. La segunda, que el cargo tenga atribuidas las facultades de más alta dirección y, la tercera, que en el Consejo no existiera delegación permanente de sus facultades en uno o varios consejeros delegados.

De ahí, que se nos plantee la cuestión de si estos altos cargos merecerían alcanzar la consideración de administrador de hecho cuando no cumplan los requisitos del art. 236.4 LSC. Al respecto, se ha considerado que estos altos cargos pueden ser administradores de hecho porque con la traslación de facultades del Consejo dirigen las sociedades ${ }^{221}$. A tal fin, en los siguientes epígrafes nuestro principal objetivo será indagar cuándo estos altos cargos, bajo el marco de su relación laboral, pueden alcanzar la consideración de administrador de hecho.

${ }^{221}$ Explicando el cargo de directivo como administrador de hecho, véanse a CUENCA MIRANDA, S., "Las competencias del consejo de administración. Las facultades indelegables del consejo. La política de control y gestión de riesgos en las sociedades cotizadas", en AA.VV., Gobierno Corporativo, cit., pp. 647-683. 


\subsubsection{El director general}

Los directores generales son aquellas personas destinadas a ejecutar las órdenes del órgano de administración, aunque cuando se encuentran en primera línea ejecutiva con facultades de alta dirección se conocen como chief executive office ${ }^{222}$, por influencia del derecho anglosajón. En cambio, en nuestro sistema, pese a su relevancia, vienen recogidos simplemente como colaboradores del empresario en el art. 282 CCom, aunque en la mayoría de ocasiones se encuentran dotados de facultades muy amplias que les facultan para poder administrar y dirigir la sociedad ${ }^{223}$. En nuestro derecho societario el director general es una figura societaria que no ha tenido una regulación específica, pues solo el art. 181 LSC lo menciona expresamente a los efectos de poder asistir a la junta general ${ }^{224}$.

Con respecto a nuestro objeto de estudio, gran parte de la doctrina se ha venido oponiendo a que se pudiera aplicar la teoría del administrador de hecho a un director general, pues les parecía excesivo que se extendiera ese estatuto de los administradores a cualquier sujeto que tenga atribuidas funciones de alta dirección ${ }^{225}$ y, sobre todo, porque la extensión

${ }^{222}$ Nomenclatura que se equipara al alto directivo utilizada en el derecho estadounidense y que tiene una configuración más amplia que un alto directivo con facultades de alta dirección, véanse GARRETA SUCH, J. M., La diligencia, cit., p. 19. Explicando las características de esta figura en Estados Unidos, SPALDING, W.R. Y LECLERC, R. J. Y HOPKINS, J. D., "General CounselDelaware Fiduciary Duties-Intersection of Developing Trends", http://www.bna.com delawerefiduciary-duties; http://www.bna.com/delawere-fiduciary-duties, 2014.

${ }^{223}$ El tratamiento de la responsabilidad de directores generales, gerentes, secretarios del consejo y no consejeros se corresponde con el ámbito de la responsabilidad general, es decir, no orgánica, véase BOLAS ALFONSO, J. M., "La financiación de la actividad social de las sociedades de capital y la situación de pérdidas desde la perspectiva del derecho mercantil actual", Revista de Derecho Privado, abril, 1994, pp. 307-332. Remontando la responsabilidad del director general a las normas del CCom sobre responsabilidad del factor, así como las normas reguladoras del mandato ESTEBAN VELASCO, G., "Algunas reflexiones sobre la responsabilidad de los administradores frente a los socios y terceros: acción individual y acción por no promoción o remoción de la disolución", $R d S$, núm. 5, 1995, p. 74. También remite la responsabilidad del Director General o Gerente al régimen del mandatario o del factor arts. 282 y ss. CCom. FERNÁNDEZ DE LA GÁNDARA Y SÁNCHEZ ÁVAREZ, Ma ., Responsabilidad de Consejeros y Altos Cargos de Sociedades de Capital, Ed. McGraw Hill, Madrid, 1996, pp. 28 y 29.

${ }^{224}$ En torno a la configuración de esta figura en nuestro sistema societario JUSTE MENCÍA, J., Factor de comercio, gerente de empresa, director general (estudio jurídico mercantil), Ed. Publicación del Real Colegio de España, Bolonia, 2003.

${ }^{225}$ Real Decreto 1382/1985, de 1 de agosto, por el que se regula la relación laboral de carácter especial del personal de alta dirección y en el art. 1.2 se considera como tal "aquellos trabajadores que ejercitan poderes inherentes a la titularidad jurídica de la empresa que son relativos a los objetivos generales de la misma, con autonomía y plena responsabilidad y sólo limitadas por los criterios e instrucciones directas emanadas de los órganos superiores de gobierno y la administración de la 
subjetiva de la responsabilidad debe limitarse a los sujetos que tienen relación orgánica con la sociedad y, en este caso, esa relación no existe.

En este mismo sentido, otras posturas menos recientes sostenían que no se podía considerar a un director general como posible administrador de hecho dadas las normas contenidas en el antiguo art. 133 SA, pues solo es un subordinado del órgano de administración vinculado a la sociedad por una relación jurídica laboral226, así que la exigencia de su responsabilidad tendría que encauzarse a través de la figura del factor, tal y como viene regulado en el CCom. No obstante, hay que advertir en la Disposición Transitoria Sexta de la LSA se mencionaba expresamente la extensión de la responsabilidad de los administradores a los gerentes y directores generales ${ }^{227}$.

A sensu contrario, otra parte de nuestra doctrina, en consonancia con el Informe Aldama, consideraba que era posible fundamentar la teoría del administrador de hecho a estas personas cuando desarrollaban las funciones propias de alta dirección. Así, defendían que el director general se colocaba en una posición cuasi orgánica cuando asumía las funciones de dirección y, de esta forma, le equiparaban al administrador de la sociedad a los efectos de exigirle responsabilidad ${ }^{228}$.

entidad que respectivamente ocupe aquella titularidad". Véanse GALLEGO SÁNCHEZ, E., El director general de las sociedades anónimas y de responsabilidad limitada, Ed. La Ley, Madrid, 2009, pp. 218-265; GUERRERO TREVIJANO, M., EL deber de diligencia de los administradores en el gobierno de las sociedades de capital, cit., pp. 381. Y VALPUESTA GAZTAMINZA, E., "Equiparación con el administrador", cit., p. 636. LATORRE CHINER, N., "El concepto de administrador de hecho", cit., p. 867.

${ }^{226}$ En contra, véanse ALONSO UREBA, A., "Presupuestos de la responsabilidad social de los administradores de una sociedad anónima", RDM, núm. 198, octubre diciembre, 1990, 662 y ss.; JUSTE MENCÍA, J., "En torno a la aplicación del régimen de la responsabilidad de los administradores al apoderado general de la sociedad", $R d S$, núm. 24, 2005, pp. 448-450; RODRÍGUEZ ARTIGAS, F., "Notas sobre el régimen jurídico del director general de la SA", en AA.VV., Estudios jurídicos en homenaje a Joaquín Garrigues, vol. III, Madrid, 1971, pp. 19 y ss.; IBARREN BLANCO, M., El seguro de responsabilidad civil de los administradores y altos directivos de las sociedades de capital, Ed. Thomson Cívitas, Cizur Menor, 2005, pp. 39-57; SÁNCHEZ CALERO, F., Los administradores, cit., pp. 242-243.

227 En este sentido MARTÍNEZ GUTIERREZ, A., "El director general de las sociedades capitalistas. Un estudio multidisciplinar", RDM, núm. 253, 2004, pp. 977-1004.

${ }^{228}$ En este sentido, ver por todos ALONSO UREBA, A., "La responsabilidad de los administradores de una sociedad de capital en situación concursal el art. 171.3 de la Ley Concursal", cit., pp. 262-313; IGLESIAS PRADA, J. L., Administración y delegación de facultades en la sociedad anónima, pp. 20 y ss. 
Sin embargo, esta teoría no se consagró al quedar derogado el art. 236 LSC que excluía a los directores generales quedando fuera del ámbito de la responsabilidad, salvo que actuaran como administradores de hecho. Los que predicaban esta teoría para fundamentar esta consideración se apoyaban en aquel criterio funcional que era defendido por la doctrina mayoritaria para calificar al administrador de hecho ${ }^{229}$.

Con la llegada de la Ley 31/2014 esta cuestión se planteó nuevamente si no concurrían los requisitos de la regla del art. 236.4 LSC, aunque, desde el punto de vista doctrinal, no cabía duda de que tanto el director general como otros altos cargos podían merecer la consideración de administrador de hecho por la ampliación de su definición legal ${ }^{230}$. No obstante, también advertían que solo responderían por esta condición cuando cumplieran el perfil funcional de administrador de hecho, es decir, que vinieran ejerciendo de forma permanente las funciones propias de un administrador societario.

Por tanto, para determinar ${ }^{231}$ la condición de administrador de hecho de estos altos cargos, cualquiera que sea su denominación, habría que tener en cuenta, primero, cuáles son las facultades delegables a estos altos directivos cuando el órgano de administración adopte la forma de Consejo y, segundo, que no exista delegación permanente de facultades en consejeros delegados ${ }^{232}$.

229 Sobre la responsabilidad, en general, del Director Gerente según sea o no administrador, ALONSO UREBA, A., "Presupuestos de la responsabilidad social de los administradores", cit., pp. 662-666. Excluye también a otros cargos técnicos de la sociedad DÍAZ ECHEGARAY, J. L., Deberes y responsabilidad, cit., pp. 398-401; LÓPEZ SANTANA, N., "Comentario a la sentencia de la Sala 1 del tribunal supremo de 30 de marzo de 2000", CCJC, núm. 54, octubre-diciembre 2000, p. 118. En el mismo sentido, MORA MATEO, J. E., "Responsabilidad Civil del administrador de la sociedad anónima", $R G D$, núm. 591, diciembre, 1993, pp. 11849- 1865. Considerando que Director Gerente tiene solo el carácter de apoderado general o factor de acuerdo con el art. 283 CCom, SÁNCHEZ CALERO, F., Administradores, cit., pp. 242-243.

${ }^{230}$ Cuando actúa con autonomía sin control del órgano de administración, véase VALPUESTA GAZTAMINZA, E., "Equiparación con el administrador", cit., p. 638. En esta línea STS de 4 de diciembre de 20123 (RJ 2405/2013).

${ }^{231}$ Este planteamiento ya fue abordado por nuestra mejor doctrina cuando se refería en las propuestas de extensión de la responsabilidad orgánica al director general JUSTE MENCÍA, J., "En torno a la aplicación de la responsabilidad de los administradores al apoderado general", cit., pp. 484450 .

${ }^{232}$ Explicando el consejo de administración de la sociedad cotizada y la reforma de Ley 31/2014, véase ALONSO UREBA, A., "El modelo de consejo de administración de la sociedad cotizada tras la reforma legal de 2014 y el CBG de 2015", cit., pp. 21-147 y pp. 118-125. 


\subsubsection{El alcance de las facultades indelegables en el administrador}

\section{de hecho}

La Ley establece importantes limitaciones para poder delegar las facultades que son propias del órgano de administración a fin de limitar la variedad de figuras con grandes poderes de alta dirección, y frenar de este modo su poder en determinadas sociedades ${ }^{233}$.

En relación con nuestro objeto de estudio, las facultades indelegables deben tenerse en cuenta con el fin de determinar qué actuaciones no son susceptibles de ser realizadas por el administrador de hecho. Por ello, brevemente haremos referencia a estas facultades que no podrían ser ejercidas por los altos cargos de dirección para poder dirigir la sociedad como administradores de hecho.

Históricamente la delegación de facultades del consejo de administración ha sido una preocupación constante en el marco del derecho de sociedades porque su continuo uso dejaba vacío de contenido obligacional al órgano de administración ${ }^{234}$. En realidad, el problema era la falta de delimitación de las facultades que eran o no delegables. Esta falta de determinación obedecía a que solo se indicaban las facultades indelegables ${ }^{235}$. De manera que el Consejo de administración, sobre todo, en las sociedades cotizadas, delegaba facultades a comisiones ejecutivas integradas por altos cargos que de hecho dirigían a la sociedad, y el Consejo se limitaba a ejercer una directiva general convirtiéndose en una instancia decorativa que solo ratificaba las decisiones adoptadas por los delegados.

Debido a esta situación, la Ley 31/2014 modificó el régimen de delegación de facultades para impedir que los altos cargos dirigieran la sociedad. Sin embargo, respetó las facultades indelegables ya recogidas en el art. 249.2 LSC, y añadió otras reconocidas por la doctrina y la jurisprudencia. Además, amplió sustancialmente las facultades establecidas en el art. 249 bis LSC al ámbito de todas las sociedades de capital, y en el art. 529 ter LSC se

233 En esta materia, GUERRA MARTÍN, G., "Las políticas societarias como facultades indelegables", cit., pp. 147 y ss.

${ }^{234}$ Véase RODRÍGUEZ ARTIGAS, F., "La delegación de facultades del consejo de administración de la sociedad anónima", $R d S$, núm.1, 1993, pp. 91 y ss.

${ }^{235}$ En este mismo sentido, explicando estas observaciones MARTíNEZ SANZ, F., "Régimen interno y delegación de facultades en el conejo de administración de la sociedad anónima", en AA.VV., Derecho de sociedades. Libro Homenaje a Fernando Sánchez Calero, cit., pp. 1761. 
recogieron las facultades indelegables para las sociedades cotizadas ${ }^{236}$. Estas modificaciones pretendían que el Consejo de administración se reservara aquellas decisiones correspondientes al núcleo esencial de la gestión y de la supervisión de la sociedad, con el objeto de que esta no quedara bajo el control de los consejeros delegados o de las comisiones ejecutivas ${ }^{237}$.

Para dilucidar qué facultades pueden ostentar los altos cargos de dirección vamos a detallar las facultades indelegables previstas en el art. 429 bis LSC a fin de delimitar qué actuaciones pueden realizar los altos cargos de dirección en su posible calificación como administradores de hecho ${ }^{238}$.

El personal de alta dirección no podrá realizar las facultades que contempla el art. 429 bis LSC, es decir, “aquellas que se corresponden con la presentación de las cuentas anuales para su aprobación por la junta general; la formulación de cualquier clase de informes que exija la Ley al órgano de administración; la convocatoria de la junta general; la elaboración del orden del día o la propuesta de los acuerdos que van a ser objeto de votación en la junta”. Por otro lado, el art. 529 bis LSC establece que las facultades indelegables en las sociedades cotizadas son: "la aprobación de los planes estratégicos o de negocio de la sociedad; el presupuesto anual; las políticas de inversiones y de financiación; la

${ }^{236}$ Sobre las facultades indelegables RECAMAN GRAÑA, E., "Los deberes y la responsabilidad de los administradores", $R d S$, núm. 45, 2016, pp. 156-1611; VELASCO SAN PEDRO, L. A., "Las facultades del consejo de administración legalmente indelegables tras la reforma de la Ley 31/2014" en AA.VV., Estudios sobre órgano, cit., pp. 213-234.

${ }^{237}$ Véanse, CULUBERT CANAL, I. Y TORRES, A., "Delegación de facultades por el consejo y facultades indelegables", en AA.VV., La reforma de la Ley de sociedades de capital, cit., pp. 81-90. El Reglamento del Banco de Santander, que señala como indelegable, Planes estratégicos, objetivos de gestión y presupuesto anual, Políticas de dividendos y de auto cartera, política general de riesgos Política de gobierno corporativo, política de responsabilidad social corporativa, las políticas de información y comunicación con los accionistas, los mercados y la opinión política, etc.; FERNÁNDEZ DE LA GÁNDARA. L., "Políticas/decisiones relevantes en materia de gestión dirección: prohibición de delegación de facultades", en AA.VV., Junta General y Consejo de administración, cit., pp. 181-226; RODRÍGUEZ ARTIGAS, F., "La delegación de facultades del consejo de administración de la sociedad anónima", cit., pp. 91-114.

${ }^{238}$ En ningún caso podrán ser delgadas las siguientes facultades: a) La determinación de la política general de la sociedad; d) la organización y funcionamiento del propio consejo, c) La distribución de las cantidades que correspondan al consejo en concepto de retribución basada en una participación en los beneficios, d) La formulación de las cuentas anuales y la presentación de dichas cuentas a la junta general, e) La formulación de cualquier clase de informe exigido por la Ley, f) Los acuerdos relativos a las acciones o participaciones propias. Sobre la Propuesta y Anteproyecto de Código Mercantil, véase BERCOVITZ RODRÍGUEZ-CANO, A., "Presentación del Anteproyecto de Código Mercantil", en AA.VV., Hacia un nuevo Código Mercantil (Coord., BERCOVITZ RODRÍGUEZ-CANO), Ed. Thomson Reuters Aranzadi, Cizur menor, 2014, pp. 37-54, y el art.231-98 Proyecto de Código Mercantil. 
responsabilidad social corporativa o el reparto de los dividendos en la sociedad". En relación con la política de gobierno corporativo y de los grupos de sociedades también se establece "la facultad indelegable de la entidad dominante o la información financiera que deberá de hacerse pública por la sociedad periódicamente; la aprobación de inversiones $u$ operaciones de cualquier tipo que tenga carácter estratégico que implique riesgo fiscal; la aprobación de creación o adquisición de participaciones en entidades de propósitos especiales y por último, la aprobación de las operaciones que las sociedades de su grupo realicen con su consejeros".

Aunque no hemos realizado un análisis pormenorizado de las facultades indelegables en los párrafos anteriores, su descripción permite destacar algunas apreciaciones que nos han surgido de su atenta lectura para poder determinar el alcance preciso de dichas facultades en relación con los altos cargos y nuestro objeto de estudio.

En este sentido, la actividad que comprende el ejercicio de estas facultades conlleva que el órgano de administración ostente un mayor grado de intervención en la sociedad y que los altos ejecutivos queden sometidos al poder de decisión del órgano de administración. De este modo, difícilmente el personal de alta dirección podrá merecer la consideración de administrador de hecho, porque no puede ejercitar las actividades que conllevan estas facultades, sobre todo, en el supuesto de las sociedades cotizadas ${ }^{239}$.

Por consiguiente, la base fundamental que obstaculizará la integración de la figura de administrador de hecho en los altos cargos de dirección estriba en las actividades que reflejan las facultades indelegables, que básicamente abordan unas materias que son de especial importancia y de responsabilidad para la gestión social.

${ }^{239}$ En torno a las facultades indelegables, véase GUERRA MARTÍN, G., "Las políticas societarias como facultades indelegables del consejo de administración", cit., pp. 52-61. 


\subsubsection{El apoderado general}

La figura del apoderado general también debe deslindarse, en ocasiones, del perfil del administrador de hecho oculto ${ }^{240}$. No se plantea problema alguno cuando actúa dentro del poder general que la sociedad le ha conferido para representarla. Resulta evidente que, en esencia, no se corresponde con el perfil legal definido como administrador de hecho ${ }^{241}$.

El factor regulado en los arts. 282 y 283 CCom, tiene conferidas amplias facultades, ocupando una posición principal en la sociedad. Así, según el art. 283 CCom, es “El gerente de una empresa o establecimiento fabril o comercial por cuenta ajena, autorizado para administrarlo, dirigirlo y contratar sobre cosas concernientes a él con más o menos facultades, según haya tenido por conveniente el propietario”. En su actuación crea una apariencia en los negocios con terceros como si fuera el verdadero administrador de la sociedad. Sin embargo, es de destacar que es un apriorismo erróneo considerar que pueda equipararse automáticamente con un administrador de hecho, porque en el apoderamiento solo se comprenden las facultades subordinadas que refleja la escritura del apoderamiento y que deberá ser inscrito en el Registro Mercantil ${ }^{242}$. Por otro lado, entre el apoderado y la sociedad existe una relación laboral regulada en el Real Decreto 2.382/1985, de 1 de agosto, que clasifica al apoderado como colaborador dependiente del empresario, y que justifica la confianza recíproca que existe entre el apoderado y la sociedad. Así que lo que predomina en la actividad encomendada al apoderado general viene predeterminado por el poder otorgado que concierne al funcionamiento ordinario de la sociedad.

De modo que, la diferencia entre un administrador de hecho y un apoderado radica principalmente en la relación jerárquica de subordinación que existe entre el apoderado y el órgano de administración. Así, al administrador le corresponde la elaboración de la política de la sociedad y los planes de gestión por ser el titular del órgano de administración; en cambio,

${ }^{240}$ Calificando a los apoderados como un posible subtipo de administrador de hecho oculto, véase, FUENTES NAHARRO, M., "Una aproximación al concepto de administrador de hecho", cit., pp. 1517; PERDICES HUETOS, A., "Significado actual de los administradores de hecho" cit., pp. 277 y ss.

${ }^{241}$ Así, lo reconoce el art. 1.5 Reglamento del Registro Mercantil ya que independientemente de que la representación la ostentan los administradores la sociedad puede conferir voluntariamente su representación a quién estime conveniente, mediante el otorgamiento del correspondiente poder.

${ }^{242}$ Los apoderados tienen facultades que dimanan de la escritura de apoderamiento; en cambio, y para la inscripción de los apoderados basta el acto unilateral de apoderamiento, véase SÁNCHEZ CALERO, F., Los administradores, cit., pp. 322-326. 
a un apoderado simplemente le compete el deber de aplicar y ejecutar dichos planes en función de las facultades encomendadas ${ }^{243}$.

No obstante, cabría que el apoderado general mereciera la calificación de administrador de hecho cuando los administradores se limiten a ratificar aquellos actos realizados por un apoderado que, dotado de conocimientos técnicos, se dedica a gestionar la sociedad alejándose del control de aquellos. En este caso, desaparecería la subordinación entre apoderado y administrador. No obstante, la consideración anteriormente expuesta resulta totalmente insostenible porque existe un claro deslinde entre ambas figuras que impedirá que se considere a esta figura como un administrador de hecho ${ }^{244}$. Ambas figuras tienen distinta naturaleza, pues el apoderado actúa bajo la cobertura legal de las reglas del mandato y sus actividades dependerán de quién le concedió el poder; por el contrario, la actividad del administrador de hecho se encuentra dotado de autonomía propia y dirigirá la sociedad ${ }^{245}$.

Sin embargo, nuestra jurisprudencia ${ }^{246}$ admitió al apoderado general como administrador de hecho si este gestiona la sociedad con independencia y autonomía. A modo

${ }^{243}$ Estableciendo la diferencia entre apoderado y administrador de hecho, véase TAPIA HERMIDA, A., "La alta dirección empresarial, (altos cargos)", en AA.VV., Estudios de derecho mercantil en homenaje al Profesor Broseta Pons, vol. III, Ed. Tirant lo Blanch, Valencia, 1995, pp. 3728 y ss.

${ }^{244}$ En este sentido desvirtuando al apoderado como administrador de hecho, véanse LATORRE CHINER, N., "Administrador de hecho y apoderado general: Comentario a la STS de 8 de febrero de 2008 (RJ 2664 /220)", cit., pp. 389-398; LATORRE CHINER, N., "El apoderado general en la Ley Concursal", cit., pp. 65-80; RODRÍGUEZ ARTIGAS, F., "Empresario Individual y representación", en AA.VV., Hacía un nuevo Código Mercantil, cit., pp. 86-88.

${ }^{245}$ Diferenciando entre la figura de apoderado y un administrador de hecho, véase RODRÍGUEZ RUÍZ VILLA D. Y HUERTAS VIESCA, Mª. I., Responsabilidad de los administradores de las sociedades de capital, cit., pp. 186-189.

${ }^{246}$ En este sentido, véanse STS de 26 de mayo de 1998 (RJ 4004/1998) donde se amparar la posibilidad de que bajo la apariencia de apoderado o factor mercantil se esconde el auténtico administrador de la sociedad ya que fácilmente puede deducirse que la titularidad mayoritaria de la empresa está en manos de la familia del apoderado, padre de los socios integrantes, y por tanto no ajeno a la marcha societaria en su conjunto porque a tenor de las facultades del apoderado se observa que son amplísimas y reafirman que, de hecho el que gestiona la marcha económica de la sociedad, a pesar de que el hijo es el administrador social, que realmente no conoce ni controla el desenvolvimiento usual de la entidad mercantil. Y STS de 7 junio de 1999 (RJ 509/1999) considera responsable de los daños y perjuicios irrogados a la sociedad al administrador de derecho, a pesar de que la audiencia consideraba responsable al apoderado nombrado por el administrador, que representaba la mayor parte del capital sociedad, olvidando que como apoderado dependía del administrador, el cual le revoco los poderes. También en SAP de Valencia de 27 de septiembre de 1999 (RJ 2523/1999) se acredita la administración de hecho con base en que el codemandado es apoderado general de la sociedad con facultades inscritas idénticas a las que en el art. 23 de los estatutos se asignan a los administradores solidarios. Tal apoderamiento es realmente amplio con 
de ejemplo, la STS de 26 de mayo de 1998 (RJ 4004/1998): cuando con amplias facultades adopta todas las decisiones de gestión en la sociedad y, además, con la circunstancia añadida de que el apoderado tiene deudas pendientes de pago que son personales con la sociedad y, aquí el apoderado debería responder como administrador de hecho ${ }^{247}$. En este sentido, la STS de 7 junio de 1999 (RJ 509/1999) también ha sostenido que cabría plantearse la equiparación automática del factor mercantil con el administrador de hecho, aunque solo si existen indicios en cada caso concreto. Entre otros indicios, la jurisprudencia en SSTS de 23 de marzo de 2006 (RJ 1596/2006), de 17 de mayo de 2007 (RJ 3405/ 2007) y de 14 de abril de 2009 (RJ 2897/2009) ha utilizado, por ejemplo, los de firmar cambiales de la sociedad, utilizar sus cuentas bancarias cuando el administrador único fallece y el apoderado ejercita acciones judiciales en nombre de la sociedad, cuando anteriormente había sido administrador y cesado continúa administrando ${ }^{248}$.

En otras ocasiones el apoderado general tiene la condición de socio mayoritario y aparece junto al administrador formal completamente ajeno a la marcha de la sociedad, y bajo aquella cobertura ejerce las funciones de administrador. En este supuesto, la subordinación que caracteriza a la figura del apoderado desaparecería y se podría convertir en administrador de hecho ${ }^{249}$. No obstante, para llegar a esta consideración deberíamos demostrar que viene

facultades, no sólo de administración sino incluso de disposición, estando facultado, entre otras, para adquirir, disponer, enajenar y gravar toda clase de bienes muebles e inmuebles; constituir aceptar, modificar y extinguir toda clase de derechos personales y reales, incluso hipoteca, así como otorgar toda clase de actos, contratos y negocios, pactar arbitrajes o transigir; tomar parte en concurso y subastas, hacer propuestas y aceptar adjudicaciones; adquirir, gravar y enajenar por cualquier título. Además, el apoderado se atribuye la condición de administrador social ante organismos públicos, y también se atribuye la condición de administrador en la certificación de acuerdos de juntas generales de la sociedad. Por ello se concluye que el apoderado gestionaba y dirigía de forma real y efectiva e incluso públicamente la sociedad.

${ }^{247}$ En este sentido, STS de 23 de marzo de 2006 (RJ 1596/2006) cuando se advierte un uso fraudulento de la facultad de apoderamiento a favor de quien realmente asume el control y gestión de la sociedad con ánimo de derivar las acciones de responsabilidad hacia insolventes, designados formalmente como administradores que delegan sus poderes, pero puede ocurrir también en otros supuestos de análoga naturaleza, como cuando frente al que se presenta como administrador formal sin funciones efectivas aparece un apoderado como verdadero, real y efectivo administrador social en SSTS de17 de mayo de 2007 (RJ 3405/2007), y más recientes STS de 12 de noviembre de 2014 (RJ 71472014); de 11 de octubre de 2014 (RJ 605/2014); de Madrid de 20 de marzo de 2015 (RJ 179 /2015), y TSJ sala de lo contencioso administrativo, de 25 de mayo de 2017(RJ 203 2017), donde el apoderado con amplios poderes celebraba contratos de arrendamiento firmaba cambiales.

${ }^{248}$ También en este sentido, véase SSTS de 14 de abril de 2009 (RJ 2897/2009).

${ }^{249}$ Explicando este supuesto concreto que constata la aparición de un apoderado que a su vez es un socio mayoritario, véanse VALPUESTA GAZTAMINZA, E., "Equiparación con el administrador", 
realizando funciones rectoras continuamente, aunque tampoco alcanzaría tal consideración cuando el administrador mantenga simplemente una actividad pasiva supervisando los actos que realiza el apoderado. Por consiguiente, podemos concluir que al apoderado general no se le podrá extender, sin más, la responsabilidad de los administradores, aunque venga desarrollando funciones de dirección en la sociedad ${ }^{250}$.

En esta misma línea hay que recordar que el art. 367 LSC excluye a los apoderados voluntarios de responsabilidad solidaria por obligaciones sociales. La justificación de esta exclusión reside en que aunque el apoderado esté dotado de facultades muy amplias no se le podía extender la responsabilidad por la omisión de la convocatoria de la junta para disolver la sociedad pues, en otro caso, se equipararía automáticamente a la categoría de administrador por falta de una actuación concreta, máxime cuando, además, el apoderado no llego a realizar las funciones efectivas de un administrador de hecho de forma constante y permanente en la sociedad $^{251}$. No obstante, este punto trataremos de explicarlo con mayor profundidad cuando abordemos la extensión de la responsabilidad por obligaciones sociales al administrador de hecho en el capítulo tercero.

En resumen, podemos afirmar que el apoderado es uno de los supuestos donde con mayor frecuencia puede manifestarse un administrador de hecho ${ }^{252}$. No obstante, no podrá alcanzar dicha calificación jurídica si actúa regularmente bajo el mandato de los administradores y en función de los poderes otorgados, ya que para alcanzar dicha calificación necesitará que de su actuación se infiera un ejercicio efectivo y continuado sin sujeción alguna a otras directrices que no sean las que se dimanan de los acuerdos que han sido adoptados por la junta general ${ }^{253}$.

cit., p. 635; SANCHO GARGALLO, I., "La extensión subjetiva de la responsabilidad", cit., pp. 623624.

${ }^{250}$ En esta materia en torno al apoderado como administrador de hecho, véase JUSTE MENCÍA, J., "En torno a la aplicación de la responsabilidad de los administradores al apoderado general", cit., pp. 444-447.

${ }^{251}$ En este sentido, ver por todos GARRETA SUCH, J. M ${ }^{\mathrm{a}}$., La diligencia, cit., pp. 24 у 25; SANCHO GARGALLO, I., "La extensión subjetiva del régimen de responsabilidad", cit., p. 623.

${ }^{252}$ Véanse JUSTE MENCÍA, J., "En torno a la aplicación del régimen de responsabilidad de los administradores al apoderado general de la sociedad", cit., p. 448. FERNÁNDEZ DE LA GÁNDARA, L., "Responsabilidad de consejeros y altos cargos de sociedades de capital", cit., pp. 28 y ss.

${ }^{253}$ Véase explicando esta consideración SANCHO GARGALLO, I., "La extensión subjetiva del régimen de responsabilidad", cit., p. 623, y STS de 4 de diciembre de 2012 (RJ 721/2012). 


\section{El administrador oculto en sentido estricto}

\subsection{Los accionistas mayoritarios}

Los accionistas mayoritarios han sido el ejemplo paradigmático del administrador de hecho, hasta tal punto que esta figura ha sido aceptada en los estudios elaborados sobre el gobierno corporativo en Estados Unidos, bajo el nombre de Dominating shardholde, que definía al administrador de hecho como el que controlaba la gestión de los negocios sociales $^{254}$. Sin embargo, debemos partir de la premisa ${ }^{255}$ de que los accionistas de control, por sí, no son administradores de hecho ni tampoco ha sido el administrador de hecho más frecuente. Así, cuando realizan injerencias en la administración solo deben considerarse como meros consejos o instrucciones que derivan del especial interés que tienen sobre la buena marcha de la sociedad en la mayoría de las ocasiones.

Descartada por el momento esta posibilidad, cabe recordar, no obstante, que el Informe Aldama equiparaba a los accionistas de control dentro del círculo de los destinatarios del cumplimiento de los deberes de los administradores. En este sentido, ya se pronunció la doctrina considerando que en el perímetro de la figura del administrador de hecho no cabría objeción alguna para que los accionistas mayoritarios se incluyeran como administradores de hecho, con el requisito imprescindible de que determinarán efectivamente la política de la empresa ${ }^{256}$.

Sin embargo, el accionista mayoritario, aunque ejerza la política de la sociedad, esta actuación no implicaría que domine la dirección en la sociedad; cuestión distinta, sería que los

${ }^{254}$ En torno a los accionistas mayoritarios, véase Principles of Corporate Governemen elaborados por la American Law Institute y las recomendaciones del UK CORPORATE GOVERNACE CODE de 2014, y sobre los accionistas de control FERNÁNDEZ PÉREZ, N., La "Companies" de 2006 y las singularidades de Buen Gobierno. Características del Derecho Inglés", en AA.VV., Junta General y Consejo de Administración, vol. II, cit., pp. 1235-1256.

${ }^{255}$ Explicando esta manifestación de administrador de hecho con el accionista de control, véanse DÍAZ ECHEGARAY, J. L., El administrador de hecho, cit., pp. 78-81; JUSTE MENCÍA, J., "En torno a la aplicación del régimen de la responsabilidad", cit., p. 400. Y los instrumentos que puede realizar el socio de control en la sociedad RODRÍGUEZ DÍAZ, I., "El administrador oculto", cit., pp. 35-36.

${ }^{256}$ Explicando que no procede la atribución automática del socio o accionista mayoritario a la condición de administrador de hecho, véanse PARDO PARDO, J. Mª ${ }^{\mathrm{a}}$, El nuevo régimen, cit., pp. 249. PAZ-ARES RODRÍGUEZ, C., "La responsabilidad de los administradores como instrumento del gobierno corporativo", cit., p. 51. 
administradores se limitaran a cumplir sus instrucciones y que estuvieran motivadas por las decisiones impartidas por los accionistas mayoritarios, entonces se enmarcarían dentro ámbito de actuación del administrador de hecho en su manifestación oculta ${ }^{257}$.

Otro dato más a favor de la exclusión del socio de control del perímetro del administrador de hecho, viene determinado por el hecho de que es completamente normal que los administradores gestionen en conexión con el socio mayoritario, pues estos deben perseguir que la marcha sociedad se encuentre determinada en gran medida por los consejos o las instrucciones de la mayoría del accionariado ${ }^{258}$. Con base en estas consideraciones, si un socio mayoritario se inmiscuye esporádicamente en la gestión, esta intromisión no implica que se convierta automáticamente en un administrador de hecho ${ }^{259}$. Por ello, debe entenderse como indicio imprescindible una cierta continuidad de injerencias en la administración que los administradores vienen ejecutando de forma automática.

Otro dato significativo viene determinado por el tipo de sociedad donde se presenta el accionista mayoritario, si es sociedad anónima abierta o cerrada y, sobre todo, si se presenta en una SRL o en una empresa familiar. Así, sería muy discutible en las sociedades de grandes dimensiones por su estructura compleja, ya que este tipo de sociedades vienen marcadas por una clase de accionariado muy disperso, y este hecho tan significativo dificultaría la presencia de un administrador de hecho de este tipo ${ }^{260}$.

De ahí que la aparición del accionista mayoritario como administrador de hecho puede darse en mayor medida en sociedades cerradas y pequeñas, donde es más frecuente que los

${ }^{257}$ En el mismo sentido PARDO PARDO, J. Mª ., El nuevo régimen, cit., pp. 249-251.

${ }^{258}$ En torno a la intervención de la junta general en asuntos de gestión antes y después de la reforma de 2014, véase ESTEBAN VELASCO, G., "Distribución de competencias éntrela junta general y el Órgano de administración, en particular las nuevas facultades de la junta sobre activos esenciales", en AA.VV., Junta General y Consejo de administración, vol. I, cit., pp. 29-82.

${ }^{259}$ En este sentido se ha pronunciado MARTÍNEZ SANZ, E., "Requisitos según la judicatura española para la consideración de la figura del administrador de hecho", Economist \& Jurist, mayo, 2013.

${ }^{260}$ Sobre la complejidad de la estructura del órgano de administración y la composición del consejo y su funcionamiento con reuniones frecuentes y las funciones de control y gestión de riesgos lo que implica la no posible injerencia en este de un accionista mayoritario que solo ofrece su opinión sobre asuntos de gestión, véase ALEJOS GARMENDIA, B., Los deberes de diligencia y de lealtad de los administradores en las empresas, cit., pp. 209-216. 
socios mayoritarios ostenten un importante poder de decisión en los asuntos de gestión, llegando incluso en ciertas ocasiones a gobernarlo.

En este sentido, nuestra doctrina jurisprudencial ha venido argumentando en SAP de Zaragoza de 16 de abril de 2014 (RJ 12572014) y SAP de Barcelona de 19 de abril de 2016 (RJ 83/2016) que, si un socio mayoritario ejerce diariamente el cargo de administrador sin sujeción alguna a las instrucciones de un tercero, merecería ser calificado como un administrador de hecho. Esto es, si la estrategia empresarial ha sido diseñada por un extraño al socio mayoritario no sería calificado de administrador de hecho, pues lo relevante es que viene "ejerciendo en realidad un poder de dirección y gestión similar al que ordinariamente incumbe a un administrador, de manera constante e independiente, sin subordinación real al administrador" ${ }^{261}$.

En cambio, otro punto de vista de nuestra jurisprudencia sostiene, en SAP de Tenerife de fecha 7 marzo de 2013 (RJ 88 /2013), que siempre que observemos que un accionista mayoritario dirige la política comercial y general de la empresa, resultaría fácilmente deducible que este de hecho controla absolutamente la dirección de la sociedad y, por tanto, debería responder por el incumplimiento de los deberes inherentes al desempeño del cargo por su condición de administrador de hecho ${ }^{262}$.

En este sentido, el mejor ejemplo paradigmático del accionista mayoritario como administrador de hecho lo encontramos en la sociedad unipersonal, porque son más proclives a que se pueda originar un abuso del poder, precisamente porque en ellas se rompe el tandem entre propiedad y control, y resultaría más fácil acreditar la confusión entre la voluntad de la sociedad y las decisiones adoptadas por el único socio. Por consiguiente, en este caso particular sería fácil demostrar que el administrador de hecho es el único socio si no se ha

${ }^{261}$ Explicando las actuaciones de socio mayoritario como administrador de hecho, véanse SSAP de Zaragoza de 16 de abril de 2014 (RJ 12572014) y de Barcelona de 19 de abril de 2016 (RJ 83/2016).

${ }^{262}$ En este sentido, véase SAP de Tenerife de fecha 7 marzo de 2013 (RJ 88 /2013) en la que se desestima el recurso interpuesto por los demandados habida cuenta de que los recurrentes forman matrimonio y contrajeron determinadas deudas actuando como administradores y que estaba constituida por sus hijos, dándose la circunstancia de que dicha sociedad carecía de patrimonio con la intención de utilizar tal ente social como mero testaferro de las operaciones generadoras de deuda. Siendo aplicable la técnica del "levantamiento del velo" utilizada por la jurisprudencia norteamericana del "disgrard of legal entity", a través de la cual, los jueces apartar la personalidad jurídica de una entidad penetrando en el estrato personal de sus miembros en aquellos casos en los que se cometen abusos para eludir un determinado cumplimiento contractual. 
nombrado un administrador distinto dada la confusión entre el administrador de derecho y el de hecho en una misma persona, pues, simplemente aplicando los requisitos establecidos por la teoría del administrador de hecho, el administrador único resultará ser de hecho. Para no llegar a interpretaciones contradictorias, en torno a la aparición automática del administrador de hecho en la sociedad unipersonal, debemos advertir que nuestra doctrina añade para este tipo de sociedad, que la sociedad sea insolvente y que se hubiera utilizado para salvaguardar el patrimonio personal del único titular de la sociedad ${ }^{263}$.

Por tanto, antes de identificar la figura de un administrador de hecho con el socio mayoritario deberemos examinar con cautela cuáles son las circunstancias concretas de cada sociedad, su tipo, para poder concretar qué posibilidad tendremos de poder encontrarnos ante la presencia de un administrador de hecho.

En conclusión, podríamos decir que actualmente sería muy discutible que el accionista mayoritario se encuentre dentro del perímetro de actuación del administrador de hecho, pues si partimos de una rigurosa distinción entre el administrador de hecho y el accionista mayoritario, únicamente cabría la posibilidad en aquellas sociedades de pequeñas dimensiones y con un accionariado restringido y, más concretamente, en la sociedad de carácter familiar ${ }^{264}$.

No obstante, cuando abordemos en los epígrafes siguientes cuáles son los indicios que nos podrían llevar a la conclusión de que un accionista mayoritario merecería ser calificado como administrador de hecho será cuando despejaremos las dudas de cuándo nos encontraremos con esta concreta manifestación de administrador de hecho.

\subsection{Los acreedores $y$ prestadores de servicios $y$ otras figuras afines bajo la} cobertura de un contrato societario

Se podría plantear que los acreedores de la sociedad pudieran alcanzar la calificación jurídica de administradores de hecho dada la amplitud de su definición legal. Sin embargo,

${ }^{263}$ En este sentido, véase DÍAZ ECHEGARAY, J. L., El administrador de hecho, cit., p. 81.

${ }^{264}$ Explicando esta consideración del accionista de control como integrante en la figura del administrador de hecho, véase PARDO PARDO, J. Mª., El nuevo régimen, cit., pp. 249-250. 
hay que advertir que esta consideración no puede realizarse de forma automática, ya que su relación con la sociedad se deriva de un contrato delimitado por las cláusulas estipuladas para el ejercicio normal de los derechos y las obligaciones del crédito que fue concedido a la sociedad $^{265}$, y, por otro lado, es normal y necesario que los acreedores traten de proteger su crédito atribuyéndose facultades de intervención en la sociedad por si aumentara el riesgo de que su crédito resultara impagado. Así, sus injerencias serían legitimas por su posición de acreedor, cuyo primordial objetivo es el de velar por el posible incumplimiento del contrato de crédito por parte de la sociedad.

No obstante, se ha venido sosteniendo que sí sería posible aplicar la teoría del administrador de hecho a los acreedores de la sociedad en algunos casos extremos, por ejemplo, cuando el acreedor "tome el mando" de la sociedad deudora impartiendo órdenes de gestión a los administradores ${ }^{266}$.

Desde el punto de vista del derecho comparado, y en particular en la doctrina italiana, se ha sostenido que no sería posible calificar a una entidad de crédito como administrador de hecho si se limita a supervisar la dirección del empleo de los fondos que se entregaron a disposición de su cliente, pues haría falta que la entidad realizara actos reiterados en la dirección que no implicaran meros actos de intención para conservar el patrimonio. En concreto, nuestra doctrina más reciente ha considerado que si el acreedor emitiera decisiones financieras que se refieren a unas actuaciones puntuales sí cabría la aplicación del administrador de hecho, siempre y cuando se demostrara que la entidad financiera actuaba en la sociedad como tal ${ }^{267}$.

Especial mención merecen aquellos acreedores refinanciadores de deuda en la sociedad como posibles administradores de hecho. El Real Decreto-Ley 4/2014 considera que un acreedor refinanciador no alcanzaría la condición de administrador de hecho salvo que en un caso concreto mereciera esta calificación. Estos acreedores serían aquellos que, bajo el

\footnotetext{
${ }^{265}$ En torno a esta corriente, véase ALFARO AGUILA-REAL, J., "Sobre administradores de hecho y subordinación de créditos ex arts. 92 y 93 LC", cit., p. 1.

266 En este sentido, véase DÍAZ ECHEGARAY, J. L., El administrador de hecho., cit., p. 30; PARDO PARDO, J. M"., El nuevo régimen, cit., pp. 252-253.

${ }^{267}$ Véanse FRASCAROLI SANTI, E., "Controlo della banca sull utilizzazione dei fondi e il dirigente di fatto", $C I, 1996$, pp. 830-832; RODRÍGUEZ DÍAZ, I., "El administrador oculto”, cit., pp. $38-40$.
} 
amparo de acuerdos de financiación, aparecen en una sociedad como administradores de hecho cuando la sociedad logra una prórroga del plazo de vencimiento de sus créditos, obtiene una ampliación del crédito o cuando una sociedad renueva su deuda ${ }^{268}$.

Otro posible administrador de hecho a plantear es el financiador de proyectos para la sociedad. En este supuesto, el administrador de hecho se presentaría cuando el promotor del proyecto obtiene la financiación necesaria para la sociedad y el financiador se inmiscuye gestionando el proyecto financiado. Sin embargo, a esta figura no se le podría calificar como administrador de hecho por dos razones fundamentales: la primera, por la remuneración que obtiene el financiador y que resultara de los beneficios del proyecto financiado y, la segunda, porque si bien el financiador se involucraría en el proyecto nunca gestiona la sociedad ${ }^{269}$.

También puede plantearse la situación de los denominados prestadores de servicios. Para considerarlos como posibles administradores de hecho tendríamos que acudir a sus injerencias en los asuntos de la sociedad bajo el amparo del contrato suscrito. Sin embargo, no pueden ser calificados jurídicamente como administradores de hecho porque no se encuentran legitimados para poder intervenir en la sociedad en base al contrato. Solo merecerían la calificación de administradores de hecho si el contrato se hubiera elaborado para disimular una verdadera administración de hecho en la sociedad ${ }^{270}$.

En este mismo marco nos encontramos con la situación del franquiciador, que es aquella figura vinculada con la sociedad bajo un contrato de dependencia donde puede existir una sumisión del franquiciado a las órdenes impartidas por el concedente o franquiciador. Sin embargo, el franquiciador no podrá alcanzar la calificación jurídica de administrador de hecho por la dependencia que existe entre esta figura y la sociedad, y que se encontraría justificada

${ }^{268}$ La no consideración del administrador de hecho en los acuerdos de refinanciación véanse BERNAD RIPOLL, F. Y LÓPEZ IGLESIAS, L., "La responsabilidad de los administradores en procesos de refinanciación", en AA.VV., Gobierno corporativo, cit., pp. 1117-1204; DÍAZ MORENO, A., "Observaciones sobre administradores, acuerdos de refinanciación, Fresh Mone y subordinación”, cit., pp. 53-76; PARDO PARDO, J. Ma., El nuevo régimen de la responsabilidad, cit., pp. 51 y ss.

${ }^{269} \mathrm{Al}$ respecto, PÉREZ DE LA CRUZ DE OÑA, C., "Financiación de proyectos. La contratación bancaria", VLex. 2007.

${ }^{270} \mathrm{El}$ rechazo de esta figura como administrador de hecho, véase DÍAZ ECHEGARAY, J. L., "E1 contrato de distribución exclusiva o de concesión", en AA.VV., Contratos mercantiles (Coord. BERCOVIZ RODRÍGUEZ-CANO), Ed. Cizur Menor, Aranzadi, 2001, pp. 296 y ss.; RODRÍGUEZ DÍAZ, I., "El administrador oculto", cit., pp. 38-40. 
en la necesidad de una unidad dimanante del contrato celebrado que, en ningún caso, puede obedecer al desarrollo de una conducta de administrador por parte del franquiciador ${ }^{271}$.

\subsection{El administrador de hecho y su alcance en los grupos de sociedades}

En este apartado deslindaremos el contorno de la dirección unitaria en los grupos de sociedades para dilucidar si los administradores de la sociedad dominante merecerían la calificación como administrador de hecho sobre las sociedades que integran un grupo, o si la sociedad dominante o las personas que ejercen la dirección unitaria del grupo alcanzarían esta calificación.

Para abordar el estudio del administrador de hecho en los grupos de sociedades debe advertirse que no se pueden integrar en este concepto por el mero hecho de que los administradores de la dominante ejerzan influencia en las filiales con las directrices de la sociedad matriz ${ }^{272}$. No obstante, cuando la dirección unitaria del grupo traspasa su contorno inmiscuyéndose en la administración de sus filiales, entonces cabría que nos planteáramos si quienes ejerzan dicha influencia alcanzarían esta condición sobre las sociedades que integran el grupo $^{273}$.

Antes de analizar en qué casos la dirección unitaria del grupo invadiría la gestión de las sociedades subordinadas debemos abordar, brevemente, cómo se ha configurado el contorno de la dirección en la sociedad matriz, pues, como es sabido, nuestro sistema societario carece de una noción jurídica sobre los grupos. La ausencia de su definición legal ha constituido una laguna muy significativa, lo que ha llevado a nuestra doctrina, ${ }^{274}$ a fin de delimitar esta

${ }^{271}$ Para mayor estudio sobre esta figura, véase DÍAZ ECHEGARAY, J. L., El administrador de hecho, cit., pp. 114-115.

${ }^{272}$ Explicado esta premisa, véanse FUENTES NAHARRO, M., Grupos de sociedades y protección de los acreedores (una perspectiva societaria), Ed. Thomson, Cívitas, Cizur Menor, 2007, p. 140; MARTÍNEZ SANZ, F., "Los administradores responsables," cit., pp. 73-75. SANCHO GARGALLO, I., "Extensión subjetiva de régimen de responsabilidad", cit., pp. 621-623.

${ }^{273}$ Este supuesto se originaría cuando los administradores trasladan su poder a la administración de las sociedades filiales, véase RODRÍGUEZ SÁNCHEZ, S. "Responsabilidad del administrador de hecho: algunos supuestos controvertidos", cit., pp. 141-148.

${ }^{274}$ Acudiendo a esta definición, véanse ARRIBA FERNÁNDEZ, M. L., Derecho de grupo de sociedades, Ed. 2a Thomson Cívitas, 2009, p. 88; MASSAGUE FUENTES, J., "La estructura interna 
institución, a recurrir a lo establecido en el art. 42 CCom, el cual recoge lo que se entiende como tal: "un conjunto de sociedades que conservando su personalidad jurídica independiente se encuentran sometidas a una dirección económica unificada"275. Otra de las definiciones de esta institución es aquella que considera al grupo como la integración de varias sociedades independientes que se encuentran bajo una dirección unitaria que englobara una unidad de decisión y de dirección económica que es común, y donde será la matriz la que ostentará el "control" de las sociedades filiales. De esta forma, por grupo de sociedades se entendería "la unidad empresarial que resulta de la articulación funcional de diversas sociedades que mantiene independencia y autonomía con un común sometimiento a una dirección económica ejercida por otra sociedad"276.

Sin embargo, las contraposiciones entre las actuaciones de los administradores de la dominante y sus filiales ha sido una realidad fáctica en los grupos y, por este motivo, el legislador se vio obligado a regularlas en el art. 18 LSC con una remisión a lo dispuesto en el art. 42 CCom, a efectos de lograr definir quién detenta el poder en los grupos de sociedades. Así, "A los efectos de esta ley, se considera que existe grupo de sociedades cuando concurra alguno de los casos establecidos en el art. 42 del Código de Comercio, y será sociedad dominante la que ostente o pueda ostentar, directa o indirectamente el control de otra $u$ otras”. Este artículo se justifica por la imposibilidad de sistematizar la problemática de las sociedades que integran el mismo grupo dado su carácter multidisciplinar, ya que en los grupos se albergan diversas modalidades de estructuras empresariales; lo que ha implicado

de los grupos de sociedades (aspectos jurídicos societarios)", RDM, núm. 192, 1989, p. 281. El grupo de sociedades es una unidad empresarial resultante de la articulación funcional de diversas sociedades independientes y autónomas a través de su común sometimiento a una dirección económica ejercida por otra sociedad"; MOYA REVERTER, J., "Los grupos de sociedades y la protección de los acreedores", RdS, 2012-1, p. 309; VICENT CHULIÁ, F., Compendio Critico, t, I, vol. 2, Ed. Bosch, Barcelona, 1991, pp. 888-907.

${ }^{275}$ La doctrina nos recuerda que nuestro derecho de sociedades carece de la noción jurídica de que es un grupo y se ha utilizado mayoritariamente la concepción contable concluye, véanse EMBID IRUJO, J. M., "El buen gobierno corporativo y los grupos de sociedades", RDM, núm. 249, 2003, p. 974; EMBID IRUJO, J. M., "Un paso adelante y varios a tras: sobe vicisitudes recientes del concepto legislativo del grupo en el ordenamiento español", $R d S$, 2008-1, p. 19. Definiendo que es un grupo, SÁNCHEZ ÁLVAREZ, M., "Fundamento del régimen jurídico de los grupos de sociedades", en AA.VV., Estudios sobre órganos de las sociedades de capital, cit., pp. 856-898.

${ }^{276}$ Este control de la matriz implica dirigir las políticas financieras y de explotación de las filiales para obtener beneficio, véanse BORNARDELL LENZANO, R., Régimen jurídico de la contabilidad del empresario, Ed. Marcial Pons, Madrid, 2012, p. 318; TAPIA HERMIDA, A., "Problemática conceptual del grupo de sociedades mercantiles", en AA.VV., Estudios sobre órganos de las sociedades de capital, cit., pp. 917-939. 
que su estudio haya sido cada día más complejo, sobre todo, por el entramado de relaciones jurídicas que existen entre todas las sociedades integrantes.

Por estos motivos resulta aún más difícil que exista la posibilidad de extender la teoría del administrador de hecho a la sociedad matriz que imparte la dirección unitaria de un grupo. Las razones fundamentales que excluyen en los grupos al administrador de hechos estriban en diversos aspectos que de manera sucinta pasaremos a exponer.

La primera, por la independencia que mantiene cada una de las sociedades dentro del conjunto del que forman parte, ya que la sociedad participada y controlada por la matriz tiende a conservar un grado de autonomía financiera y de gestión que le permitirá orientar sus actividades sin injerencia externas en la consecución de su interés social. La realidad de su autonomía llega hasta tal punto que las deudas asumidas por cada sociedad, dentro de su grupo, solo se pueden reclamar a la sociedad obligada al pago. La segunda, porque su administración no se encuentra subordinada entre las sociedades del grupo; por tanto, el apriorismo de que los grupos de sociedades pueden equipararse a la técnica del levantamiento del velo o a la teoría de los administradores de hecho nunca ha tenido fundamento alguno por ser erróneo, aunque no se puede obviar que estas dos teorías presentan puntos en común para lograr el objetivo de exigir la responsabilidad a quienes traspasen el contorno de la dirección unitaria en los grupos 277 .

En este sentido, deberíamos discernir si los grupos de sociedades se han utilizado para poder conseguir los propios intereses de otras personas físicas o jurídicas y, si así ocurriera, si sería justificable acudir al recurso de la justicia material para sancionar a aquellas personas que se han amparado en el formalismo societario de los grupos de sociedades con el objetivo de eludir el cumplimiento de sus obligaciones o sus responsabilidades ${ }^{278}$.

${ }^{277}$ Véase MORENO SERRANO, E., "Responsabilidad de la sociedad matriz como administrador de hecho", en AA.VV., Estudio sobre la responsabilidad de los administradores de las sociedades de capital a la luz de sus recientes reformas, cit., pp. 253-265.

${ }^{278}$ En este sentido explicando el mal uso de esta institución y descubriendo en su caso, el dolo o abuso cometido y la posibilidad de sancionar a quienes la manejan con una determinada sociedad, véanse GARRETA SUCH, J. M., La diligencia, cit., p. 33; GIRGADO PERANDONES, A., La responsabilidad de la sociedad matriz y de los administradores de una empresa de grupo, Ed. Marcial Pons, Madrid, 2002, pp. 176-179. 
No obstante, ha sido una cuestión pacífica y consolidada que el elemento esencial que viene a caracterizar a un grupo societario es la capacidad corporativa para poder coordinar el grupo de sociedades. Este elemento sirve para asegurar la unidad del grupo y encuentra su manifestación en aquella influencia que viene ejerciendo el órgano de administración de la matriz en las actividades económicas de las sociedades filiales ${ }^{279}$. De ahí que, el grupo de sociedades se encontrará fuera del marco de la figura del administrador de hecho al estar integrado y compuesto de un elemento llamado "unidad de dirección" o de coordinación, cuya titularidad la ostenta la matriz para conseguir la ejecución del interés del grupo, es decir, la sociedad matriz asume la gestión efectiva de las filiales con una dirección unitaria que tiene la función de planificar y coordinar las actividades económicas de las filiales y dirigir la política económica del grupo, pero no administra las filiales, ya que cada una de la sociedad que integran el grupo tienen un órgano de administración propio e independiente de la matriz ${ }^{280}$.

Una vez que hemos analizado de una manera sucinta la actuación que comprende la sociedad matriz en los grupos, al trasladarnos a nuestro objeto de estudio debemos partir de la siguiente premisa: la aplicación de la figura del administrador de hecho no opera en los grupos de sociedades automáticamente ${ }^{281}$. De ahí que, por el momento, descartamos que el administrador de hecho se integre en la dirección unitaria de la matriz, ya que para poder alcanzar esta consideración esta tendría que realizar un ejercicio de la actividad administrativa o gestora en las sociedades filiales de una forma reiterada y sistemática, y no meramente esporádica $^{282}$.

${ }^{279}$ La influencia para asegurar la unidad del grupo de sociedad, véase ALONSO UREBA, A., "Algunas cuestiones en relación con el ámbito subjetivo de la responsabilidad de los administradores (administradores de hecho, administrador oculto y grupos de sociedades", en AA.VV., La responsabilidad de los administradores de sociedades de capital (Coord. GUERRA MARTÍN), Ed. La Ley, Madrid, 20011, pp. 87-102.

${ }^{280}$ Explicando el contorno de dirección de un grupo de sociedades, véanse ALONSO UREBA, A. Y PULGAR EZQUERRA, J., "Relación de grupo y administrador de hecho en el concurso de sociedades integradas en un grupo", cit., pp. 25 y ss.; EMBID IRUJO, J. M., "Grupos de Sociedades y Derecho concursal", en AA.VV., Estudios sobre la Ley Concursal. Libro homenaje a Olivencia. Madrid, 2005, T. III, pp. 1885 y ss.; GIRGADO PERANDONES, P., La empresa del grupo y el Derecho de Sociedades, cit., pp. 10 y ss.; SÁNCHEZ ÁlVAREZ, M. M., "Grupos de sociedades y responsabilidad de los administradores", cit., pp. 122 y ss.; SÁNCHEZ-CALERO, F., "Algunas cuestiones concúrsales relativas a los Grupos de Sociedades", $A D C$, núm. 5, 2005, pp. 24 y ss.

${ }^{281}$ Véase ALONSO UREBA, A., "Administrador de hecho y grupo de sociedades", Otrosí, núm. 12, octubre-diciembre, 2012, p. 25.

${ }^{282}$ Véase SANCHO GARGALO, I., "La extensión subjetiva del régimen de responsabilidad", cit., pp. 621-623. 
No obstante, y como ya se ha indicado, la figura del "administrador de hecho" entraña una cierta correlación con la técnica del levantamiento del velo, y con cierta cautela podríamos extender los criterios de la doctrina del administrador de hecho, tomando como base aquellas instrucciones que son impartidas por la sociedad matriz a los administradores de las sociedades dominadas, si concurren las pautas que nos pueden servir para averiguar la posible posición de un administrador de hecho en los grupos de sociedades. Su presencia se deduciría de la aquiescencia o tolerancia de los accionistas de la sociedad dominada, ya que fácilmente podríamos dilucidar si el administrador de hecho sería un socio mayoritario de la cabecera cuando dirige la gestión empresarial de una filial e, incluso, cuando cesara a los administradores de derecho de las filiales por no cumplir con las directrices de la matriz ${ }^{283}$.

También se podría considerar administrador de hecho a la persona que ostenta la condición de un administrador u otro cargo representativo en la sociedad directora del grupo. Esta consideración ha sido objeto de posturas contrapuestas, pues la mayor parte de la doctrina considera que esta manifestación del administrador de hecho resultaría insostenible en los grupos ${ }^{284}$, apoyándose en que no deben de extenderse los deberes de los administradores a aquel sujeto que asume simplemente algunas de las funciones de alta dirección, entre ellos, los administradores de la sociedad dominante.

Otro argumento para excluir al administrador de hecho son las instrucciones en los grupos, pues se considera normal que en los grupos se impartan directrices y medidas tendentes a coordinar operaciones con esquemas globales de planificación dictadas por la sociedad matriz para que sean aplicados en las sociedades filiales y en interés del grupo y, por

${ }^{283}$ Un análisis detallado sobre la responsabilidad de la sociedad matriz como administrador de hecho, MORENO SERRANO, E., "La responsabilidad de la sociedad matriz como administrador de hecho", en AA.VV., Derecho de Sociedades, Revisando el derecho de sociedades de capital (Coord. OLMEDO PERALTA Y GALACHO ABOLAFIO), Ed. Tirant Lo Blanch, Valencia, 2018., pp. 13291342.

${ }^{284}$ Defendiendo esta postura de la insostenibilidad del administrador de hecho en los grupos, véanse GRIMALDOS GARCÍA, Ma . I., "Presupuestos y extensión subjetiva de la responsabilidad. Solidaridad: artículos 236 y 237. Otras acciones por infracción del deber de lealtad: artículos 221.2 y 231", en AA.VV., Régimen de deberes, cit., pp. 307-358; LARGO GIL, R. Y HERNÁNDEZ SÁINZ, E., "La imputación de responsabilidad civil en el seno de los grupos de sociedades", en AA.VV., Descentralización productiva y responsabilidades empresariales. El "outsourcing” (Dir. RIVERO LAMAS), Ed. Aranzadi, Pamplona, 2003, p. 432. 
estas razones, la sociedad dominante no podría resultar administrador de hecho por impartir estas instrucciones a las filiales ${ }^{285}$.

Sin embargo, cuando la dirección unitaria del grupo traspasara sus contornos invadiendo la administración de las filiales podría calificarse como administrador de hecho si concurren una serie de requisitos. Primero, que las directrices impartidas por la sociedad dominante influyan en la administración de las filiales ${ }^{286}$. Segundo, el grado de centralización entre la sociedad dominante y las sociedades dominadas (grado que deberá valorarse atendiendo a los actos realizados por los administradores de las sociedades filiales). Tercero, si los administradores de las filiales obedecen decisiones de carácter orgánico impartidas por la matriz y tales decisiones cumplen las exigencias de los procedimientos y competencias de su órgano de administración, entonces la sociedad dominante sí sería el administrador de hecho de la dominada ${ }^{287}$.

Desde la perspectiva del derecho comparado la doctrina inglesa ${ }^{288}$ entiende que solo cabría esta posibilidad si las instrucciones de la matriz se refieren a transacciones que han sido

${ }^{285}$ En este sentido, hay que distinguir entre la dirección unitaria y el mero control con una estructuras centralizadas y descentralizadas de los grupos, entre otros, véanse DUQUE DOMÍNGUEZ, J. F., "Concepto de grupo de sociedades y su significado en el derecho español", cit., pp. 5303-5322; EMBID IRUJO, J. M., Grupos de sociedades y accionistas minoritarios (la tutela de la minoría en situaciones de dependencia societaria y grupo), Ed. Ministerio de Justicia, Madrid, 1987, p. 73 y ss.; MARTÍNEZ MACHUCA, P., La protección de los socios externos en los grupos de sociedades, Bolonia, 1999; MASSAGUE FUENTES, J., "La estructura interna de los grupos de sociedades", cit., p. 281; ROJO FERNÁNDEZ-RÍO, A., "Los grupos de sociedades", RDM, núm. 220, 1996, p. 457 y ss.; SÁNCHEZ CALERO, F., "De nuevo sobre la regulación de los grupos de sociedades", $R D B B$, núm.77, 2000, p. 7 y ss.

${ }^{286}$ En el proyecto de la novena directiva de Grupos de 1984 disponía en su art. 9 "que cualquier empresa que en relación a la sociedad se comporte como un administrador de hecho, debe responder por cualquier daño derivado de su actuación y causado por un error en la administración, ello en las mismas condiciones que si la empresa hubiera sido integrante de los órganos de dirección de la sociedad y, en consecuencia, hubiera estado sometido al deber de velar por el interés de la sociedad". La misma norma entiende por administrador de hecho "a toda empresa que, directa o indirectamente, ejerza una influencia sobre la adopción de decisiones de los órganos de dirección de la sociedad", véase SÁNCHEZ ÁLVAREZ, M. D., "Grupos de sociedades y responsabilidad de los administradores", cit., pp. 122 y ss.; GIRGADO PERANDONES, P., "La responsabilidad de la matriz de una empresa de grupo por las deudas de sus filiales en Derecho Español. Situación legislativa y actuación de los tribunales", cit., pp. 116 y ss.

${ }^{287}$ Defendiendo esta corriente, véanse ARRIBA FERNÁNDEZ, M. L., Derecho de grupos de grupos sociedades, cit., p.161 y ss. y 400 y ss.; FUENTES NAHARRO., M., Grupos de sociedades y protección de acreedores, (una Perspectiva societaria), cit., p. 284 y ss.

${ }^{288}$ Véase La Section 251 de la Companies Act Inglesa de 2006 en su apartado tercero; GOWER, D., Principles or modern Company Law, Ed. Thompson, Londres, p. 485. 
aprobadas por sus socios y los administradores de la filial actúan conforme a estas directrices ${ }^{289}$. Así, el hecho de que la matriz imponga una política común al grupo no implicará que asuma la condición de administrador de facto.

Por otro lado, también se ha planteado doctrinalmente si los administradores de la dominante pueden ser considerados como administrador de hecho de la sociedad dominada. Lo más frecuente ha sido que los administradores se han valido de los administradores de las filiales como hombres de paja, ya que se limitan a cumplir sus instrucciones, o cuando administradores de la sociedad matriz utilizan a terceros que, dotados de amplios poderes, dirigen a los administradores de las filiales ${ }^{290}$.

Por consiguiente, los administradores formales de las sociedades dominantes sólo alcanzarían la calificación de administradores de hecho en las sociedades filiales cuando concurran los siguientes requisitos. El primero, por actuaciones que se traduzcan en actividades que son propias de gestión o administración en la sociedad dominada y, el segundo, que las instrucciones se desarrollen continuamente. Por consiguiente, la consideración de administrador de hecho solo encajaría en determinados casos muy $\operatorname{limitados}^{291}$.

Y, por último, para encuadrar al administrador de hecho en los grupos deberemos distinguir entre el administrador de hecho indirecto, que actuara desde la cabecera del grupo, y el administrador de hecho directo, que serían los administradores de la matriz cuando imparten instrucciones a los administradores de las sociedades filiales. Así que, para poder presentarse un administrador de hecho en los grupos de sociedades sería necesario que los administradores de la sociedad matriz impartieran instrucciones que no sean para coordinar la forma estratégica el grupo y que no se refieran a la coordinación del grupo; en ese caso los

\footnotetext{
${ }^{289}$ Véase, RODRÍGUEZ DÍAZ, I., "El administrador oculto”, cit., p. 25.

${ }^{290}$ Explicando los medios utilizados para dar instrucciones en los grupos, que incluye un variopinto elenco de administradores de hecho que van desde la sociedad dominante del grupo y el socio único a los que se han denominado "administradores bausán, administradores florero, administradores testaferros o administradores matrioshka", PRADES CUTILLAS, D., Administradores de hecho: tipología no tan encubiertas, cit., pp. 5-11.

${ }^{291}$ En este sentido, RODRÍGUEZ SÁNCHEZ, S. la responsabilidad del administrador de hecho: algunos supuestos controvertidos", cit., p. 144.
} 
administradores de la dominante alcanzarían la posición de administrador de hecho en las sociedades filiales ${ }^{292}$.

En síntesis, la teoría del administrador de hecho debe de aplicarse en un sentido muy restringido en los grupos en aras a la seguridad jurídica, sobre todo, con respecto al administrador de hecho oculto, y resultaría justificable su exclusión automática porque la administración de la sociedad matriz es conocida externamente por todos. En cambio, podría darse esta posibilidad en su manifestación oculta en los administradores de la dominante y cuando se demostrase esta consideración, la cual será objeto de estudio cuando abordemos la actuación del administrador de hecho en el epígrafe siguiente ${ }^{293}$.

\section{LA PRUEBA DE LA ACTUACIÓN DEL ADMINISTRADOR DE HECHO}

La LSC nos trajo la esperada definición de administrador de hecho en su art. 236, aunque sus términos son tan significativamente amplios que plantean el problema de cómo demostrar todas las combinaciones que comprenden. Por otra parte, con la definición de administrador de hecho debemos tener cautela para evitar que se produzca indiscriminadamente la calificación de administrador de hecho a cualquiera de los sujetos que pueden subsumirse en su descripción. En especial, el problema se agrava en el administrador de hecho oculto por la trazabilidad que se alberga en su definición, que revela una gran opacidad. La razón de la especial dificultad que reviste la demostración del administrador de hecho oculto viene determinada por su característica especial: su actuación es oculta, lo que se traduce, por un lado, en que debemos demostrar su actuación bajo la apariencia de cualquier título y, por otro lado, en la necesidad de acreditar su actuación de forma oculta ${ }^{294}$.

${ }^{292}$ Defendiendo esta postura GARCÍA-CRUCES GONZÁLEZ, J. A., Administradores sociales y administrador de hecho, cit., p. 31 y 32.

${ }^{293}$ En este sentido EMBID IRUJO, J. M., "Algunos criterios de política jurídica para la regulación de los grupos de sociedades", en AA.VV., Derecho de sociedades Revisando el derecho de sociedades, cit., pp. 355- 358; SÁNCHEZ CALERO, F., Los administradores, cit., p. 316.

294 A este respecto se ha pronunciado nuestra doctrina explicando cómo se identifica un administrador de hecho por su modo de actuar, véase RODRÍGUEZ DE LAS HERAS BALLELL, T., "Requisitos para ser administrador y extensión subjetiva de la responsabilidad", cit., p. 751. 
Este objetivo se conseguirá recurriendo, fundamentalmente, al examen de toda una serie de indicios que principalmente irán dirigidos a demostrar quién es el administrador de hecho que actúa en la sombra, ya sea dentro o fuera de la sociedad y, subsidiariamente, haciendo uso de esta demostración acreditaremos que los administradores se encuentran dirigidos por el administrador de hecho oculto, y así lo haremos, tal y como establece la SAP de Barcelona de 9 de enero de 2014 (RJ 5/2014), demostrando que el administrador de hecho no ostenta criterio o juicio alguno para administrar ${ }^{295}$.

No obstante, no cabe desmerecer otra problemática, que consiste en cómo demostrar el resto de combinaciones que presenta el administrador de hecho. El motivo de que no resulte fácil esta demostración reside en que el art. 236. 3 LSC no establece reglas formales, sino que se limita a dibujar su perfil funcional, dejando la puerta abierta a una amplitud de sujetos que puedan ser consideramos como administrador de hecho.

En este sentido, la demostración versará296, según sentencia del juzgado de lo mercantil de Madrid de 3 de junio de 2014 (RJ 5/2014), sobre la absoluta autonomía de su actuación, la continuidad en el tiempo y su participación efectiva en el desarrollo de las actividades administrativas y, sobre todo, en el completo ejercicio del poder de dirección ${ }^{297}$. No obstante, la perfecta demostración de la presencia del administrador de hecho solo se consumará con la demostración de la aceptación y tolerancia de las actuaciones realizadas por la sociedad. La prueba de la presencia del administrador de hecho, según STS de 14 de abril de 2009 (RJ 2897/2009), y más reciente SAP de Madrid de 27 de enero de 2017 (RJ 37/2017), debe ser siempre valorada atendiendo a las circunstancias de cada sociedad ${ }^{298}$.

${ }^{295}$ En este sentido SAP de Barcelona de 9 de enero de 2014 (RJ 5/2014) mantiene que los apoderados por el simple hecho de serlo no son administradores de hecho pues no puede ser administrador de hecho quién actúa por mandato de otro, en cambio el supuesto ejemplar del denominado administrador oculto se identificaría a través de pruebas directas como testificales que acrediten que el que adoptaba las decisiones importantes era el administrador oculto y que el administrador de derecho era un cargo puramente formal.

${ }^{296}$ En este sentido, la sentencia del juzgado de lo mercantil de Madrid de 3 de junio de 2014 (RJ 5/2014) reitera los requisitos que ya venían establecidos por nuestra jurisprudencia.

${ }^{297}$ Sobre notas características de esta figura, véase VALPUESTA GASTAMINZA, E., "La Equiparación con el administrador de la persona que tenga atribuidas facultades de más alta dirección", cit., pp. 633 y ss.

${ }^{298}$ En este sentido, véase STS de 14 de abril de 2009 (RJ 2897/2009) y más reciente SAP de Madrid de 27 de enero de 2017 (RJ 37/2017) en la que se rechaza la condición de administrador de hecho a un apoderado, a pesar, de comprar acciones en nombre de la sociedad porque el administrador de derecho 
Por consiguiente, el problema consistirá en demostrar su actuación, precisamente, porque es un hecho y como tal requerirá probarse.

\section{Necesidad de prueba del administrador de hecho}

Debido a la inconcreción de la definición legal de administrador de hecho, y con la finalidad de evitar que cualquier sujeto pueda ser considerado como tal, debemos contraponer sus actuaciones a las de otras figuras que solo desarrollan las facultades inherentes a su cargo. Posteriormente, acreditaremos su condición con una demostración adecuada, ya que su definición legal no señala las pautas concretas de actuación en cada una de sus manifestaciones, ni tampoco dispensa la prueba de tal condición ${ }^{299}$. A tal efecto, la demostración deberá ser diligente y proporcionada para el caso concreto que va a resultar analizado $^{300}$, por haberse configurado jurídicamente al administrador de hecho en una situación de hecho en el desempeño de funciones propias del administrador en la realidad del tráfico, y como tal "hay que probarla", con una prueba bastante y ponderada que acredite esta realidad. Este objetivo se logará acudiendo, fundamentalmente, a los medios de prueba que se recogen en el art. 1215 CC y, subsidiariamente, a las circunstancias concretas de cada caso.

Se trata de poder concluir qué se deberá de entender por administrador de hecho "probado". A estos efectos, la doctrina jurisprudencial, en STS de 24 de febrero de 2014 (RJ 59/ 2014), ha venido sosteniendo que, para activar la acción de responsabilidad contra el administrador de hecho, el accionante necesitará conocer cómo probar esa condición jurídica $^{301}$. En primer lugar, conviene matizar qué se entiende por administrador de hecho

no ha dejado de ejercer sus funciones en la sociedad y además el apoderado no ha realizado más funciones de los administradores en nombre de la sociedad.

299 Esta manera de proceder del legislador para establecer la definición de administrador de hecho en el art. 236.3 LSC cualquier persona podría ser calificada como administrador de hecho por realizar actos de administración, véase EMBID IRUJO, J. M., "Todos son (y serán) administradores”, cit. pp. 1 y ss.

${ }^{300}$ La demostración del administrador de hecho en STS de 24 de febrero de 2014 (RJ 59/2014), véase PASTOR SEMPERE, C., "Comentarios a la Sentencia del Tribunal Supremo de 24 de febrero de 2014", en AA.VV., Archivo Commenda (Dir. EMBID IRUJO), Ed. Comares, 2013/2014 y la necesidad de prueba del administrador de hecho, SÁNCHEZ-CALERO GUILARTE, J., "Administrador de hecho: ¡hay que probarlo!”, cit., pp. 1-3.

${ }^{301}$ En este sentido conforme a la STS de 24 de febrero de 2014 (RJ 59/ 2014) debemos fijar nuestra atención sobre los argumentos de qué se debe entender por alegación de la condición de administrador 
"probado". Así, desde el momento que se identificó a un posible sujeto como administrador de hecho, deberemos asumir la carga de demostrar las circunstancias que permitirán al tribunal afirmar que el sujeto merece ser calificado como tal. En segundo lugar, deberá demostrarse que el administrador de hecho, independientemente de cuál sea su manifestación, actúo desempeñando funciones propias de los administradores y, por último, será necesario demostrar el marco temporal de las actuaciones que son susceptibles de generar la referida responsabilidad frente al acreedor reclamante ${ }^{302}$.

Por tanto, la necesidad de una prueba que sea adecuada la encontraremos entre los distintos medios de prueba que vienen reconocidos por nuestra legislación. Merecen especial atención las llamadas pruebas directas, como $v$. gr., el interrogatorio del administrador de derecho de la sociedad y de la persona que supuestamente puede ser administrador de hecho. Además, deberíamos demostrar cuáles son los hechos que nos han permitido concluir que nos encontramos ante un posible administrador de hecho. Entre los hechos que pueden ser relevantes pueden citarse los siguientes:

En primer lugar, el hecho de que el administrador de la sociedad no se encuentra dotado de los conocimientos técnicos y profesionales que se requieren para la dirección de la sociedad, ya que ostenta una categoría profesional diferente que no tiene relación alguna con la actividad social de la sociedad ${ }^{303}$. Para ello se pueden utilizar una serie de indicios para acreditar que el administrador de derecho es una persona ajena a la administración que supuestamente administra. En segundo lugar, el hecho de determinar cuál es el lugar de residencia del administrador formal, es decir, si reside cerca del domicilio social que supuestamente administra o en otra localidad distinta.

de hecho y su prueba. "De todo lo anterior deduce que la sentencia "ha incurrido en un "error patente" lo que además la hace incongruente», primero, por considerar que la alegación sobre la caducidad del cargo, acaecida en junio de 2001, es una alegación formulada ex novo, y segundo, por considerar que la actuación del administrador con posterioridad a 2001 no fue probada".

${ }^{302}$ Véase PASTOR SEMPERE, C., "Comentarios a la Sentencia del Tribunal Supremo de 24 de febrero de 2014 (RJ 59/2014)", cit., p. 1-3. Se desestima la demanda por prescripción del plazo de cuatro años para presentar la demanda en un supuesto de administrador de hecho con cargo caducado" no se alegó que, tras la caducidad de su cargo, que el administrador que hasta ese momento lo había sido "de derecho", lo siguiera siendo "de hecho".

303 En torno a la profesionalidad como diligencia del administrador FERNÁNDEZ DE LA GÁNDARA, L., Derecho de Sociedades, Ed. Tirant Lo Blanch, Madrid, 2010, p. 738. 
Otra de las pruebas directas para demostrar la presencia de un administrador de hecho es la prueba testifical de las personas que rodean el ámbito de la actuación de la sociedad, entre ellas señalamos, a modo de ejemplo, a los trabajadores de la empresa que son los que precisamente podrían indicar si conocen al administrador de derecho, si un administrador de hecho en su manifestación oculta es quién viene ejerciendo labores de administración diariamente, si les consta si es el administrador formal el que dirige a la empresa, o si ni tan siquiera lo conocen ${ }^{304}$.

De vital importancia para demostrar la actuación de un administrador de hecho es la prueba pericial, que consistiría, por ejemplo, en determinar que el administrador formal se encuentra falto de capacidad de obrar, lo que determinaría automáticamente que es otra persona la que se encuentra actuando como administrador de hecho ${ }^{305}$.

Por último, también aludiremos a la prueba indirecta de las presunciones referida en la SAP de Zaragoza de 23 de noviembre de 2012 (RJ 602/2012). Se trata de una prueba principal que, como es sabido, se construye sobre la base de indicios ${ }^{306}$ que conducirán a la obtención de un resultado; en este caso, de que el administrador formal es un mero instrumento en manos de la persona que actúa como un administrador de hecho ${ }^{307}$. Es decir, se trata de demostrar que el sujeto realiza funciones que corresponden a los administradores con autonomía de forma habitual, participando directamente en las decisiones importantes de la sociedad. También la STS de 22 de julio de 2015 (RJ 421/2015) considera los indicios que nos permitirán presumir su consideración como administrador de hecho, tal y como se establecen en el art. 1253 CC $^{308}$. La SAP de Pontevedra de 1 de enero de 2016 (RJ 17/2016)

\footnotetext{
304 En este sentido, los apoderados que administran las empresas porque ha fallecido el administrador único, véase STS de 14 de abril de 2009 (RJ 2897/2009).

${ }^{305}$ Véase La capacidad para ser administrador, GALLEGO SÁNCHEZ, E., "Los administradores", cit., pp. 1512-1518.

${ }^{306}$ La necesidad probatoria del administrador de hecho acudiendo a las presunciones, véase SAP de Zaragoza de 23 de noviembre de 2012 (RJ 602/2012).

307 La importancia de la prueba de indicios, MARTín SANZ, F., "Los administradores responsables", cit., pp. 62-69.

308 Conforme establece nuestra doctrina jurisprudencial en SSTS de 22 de julio de 2015 (RJ 421/2015) con remisión a la STS de 4 de diciembre de 2012 (RJ 721/2012) declara que los administradores de hecho son "quienes, sin ostentar, formalmente el nombramiento de administrador y demás requisitos exigibles, ejercen las funciones como si estuviesen legitimados prescindiendo de tales formalidades, pero no a quienes actúan regularmente por mandato de los administradores o como gestores de éstos, pues la característica del administrador de hecho no es la realización material de
} 
dispone que habría que demostrar el daño causado y la relación de causalidad entre el acto realizado por el administrador de hecho y su resultado ${ }^{309}$.

Y, por último, alegar la condición de administrador de hecho, que deberá ser en todo caso clara y expresa. Esto no significa que no se pueda recurrir a la prueba de las presunciones, muy al contrario, con esta prueba se acudirá al examen de los indicios que nos harán presumir esta condición, pues la prueba de las presunciones ha sido calificada como la más importante para poder apreciar aquellas situaciones irregulares u ocultas. Así, la STS de 14 de abril de 2009 (RJ 2897/2009) cuando dice que, "En el ámbito societario puede aparecer la figura del administrador de hecho, que actúa como verdadero gestor social, requiriéndose para poder apreciar estas situaciones irregulares y ocultas, la necesaria prueba, si bien es cierto que la directa en la mayoría de los casos resultará imposible, por lo que el camino procesal más apto es la prueba indiciaria"’310.

\section{Indicios generales de identificación del administrador de hecho}

Siguiendo la línea de desarrollo de cómo podríamos demostrar la actuación del administrador de hecho, debemos acercarnos a aquellos indicios que nuestra doctrina y jurisprudencia han ido implementado atendiendo a las particulares circunstancias de cada tipo

determinadas funciones, sino la actuación en la condición de administrador con inobservancia de la formalidades mínimas que la Ley o los estatutos exige para adquirir tal condición" en este sentido se fueron apreciando que estos cargos societarios a la vista la prueba practicada, se deduce que los apoderados codemandados participaban de forma activa en la marcha social, adoptando decisiones que rebasaban el ámbito del simple proceso productivo, por lo que procedía la condena solidaria a los mismos.

${ }^{309}$ En este sentido se manifestó la SAP de Pontevedra de 1 de enero de 2016 (RJ 17/2016) que considera que los correos cruzados entre las partes han de ser tenidos en cuenta en la valoración conjunta de la prueba para determinar la existencia o no del acreedor como administrador de hecho de la sociedad.

${ }^{310}$ En este sentido STS de 24 de febrero de 2014 ( RJ 59/2014) y SAP de Madrid de 29 de abril de 2016 (RJ 16272016) que recoge la no consideración responsabilidad como administrador de un apoderado, a pesar, de ostentar un poder general con amplios poderes, tomar decisiones sobre la vida económica de la sociedad porque para alcanzar esta consideración hacen falta tres indicios i) los administradores de hecho tiene vinculaciones de parentesco con los administradores normalmente nombrados por la sociedad como hijos del apoderado ii)el apoderado negociaba y contratan en nombre de la sociedad sin ni siquiera informar los términos de los contratos con los administradores formales y iii) las amplísimas facultades concedidas al apoderado.

\footnotetext{
${ }^{310}$ En este sentido, véase STS de 14 de abril de 2009 (RJ 2897/2009).
} 
de sociedad. Pues bien, en este sentido, resaltaremos los indicios generales que, según STS de 4 de diciembre de 2012 (RJ 721/2012), nos servirán de apoyo para presumir que un sujeto viene ejerciendo las actuaciones específicas que corresponden a las competencias del órgano de administración ${ }^{311}$.

El primer indicio lo encontramos en los términos del poder otorgado a la persona que se pretende atribuir la calificación jurídica de administrador de hecho. Así que, el poder debe abarcar, no solo aquellos aspectos de una actuación externa, sino que además deberá alcanzar facultades que implique gestión interna, es decir, que las facultades sean tan amplias que prácticamente sean idénticas a las que se corresponden con el administrador de derecho.

El segundo, la actuación del sujeto. Para poder inferir que no nos hallamos ante un mero empleado sino que más bien se trata de un verdadero administrador, señalamos lo apuntado por la Sentencia del juzgado de lo mercantil de Madrid de 3 de junio de 2014, (RJ 77/2014) que se refiere al indicio de firma de cambiales que generan deuda a la sociedad, al sujeto que sin título convoca la junta general, solicita el cambio del domicilio social o solicita el acuerdo de la disolución de la sociedad o, incluso, si convoca la junta para el caso de aumentos de capital ${ }^{312}$.

En tercer lugar, situaciones particulares. Según SAP de Barcelona de 6 de febrero de 2014 (JUR 158831/2014), v. gr., un sujeto que no ostenta poder alguno y asume voluntariamente una situación de endeudamiento para la sociedad que evidentemente es muy superior a sus posibilidades reales ${ }^{313}$.

En cuarto lugar, amplios poderes. Este indicio se manifiesta cuando el sujeto realiza toda una serie de actos de representación contratando con terceros en nombre de la sociedad.

En quinto lugar, las compras de participaciones sociales. Señalaremos como más significativas el caso particular de aquel sujeto que realiza préstamos de inyección económica en la sociedad para solventar sus dificultades financieras.

\footnotetext{
${ }^{311}$ Constatando la prueba de estos indicios, véase STS de 4 de diciembre de 2012 (RJ 721/2012).

${ }^{312}$ Explicando los indicios de actuación de un administrador de hecho, véase sentencia del Juzgado de lo Mercantil de Madrid de 3 de junio de 2014, (RJ 77/2014).

${ }^{313}$ Declarando estos indicios, véase SAP de Barcelona de 6 de febrero de 2014 (JUR 158831/2014).
} 
El sexto lugar, participación efectiva. Este indicio considerado como fundamental se construye por actuaciones concretas cuando el sujeto utiliza las cuentas bancarias de la sociedad, aunque actúe como un simple autorizado, o si presentara la solicitud del concurso cuando la sociedad se encuentra en estado de insolvencia y, posteriormente, este mismo sujeto viene colaborando con la administración concursal ${ }^{314}$.

Séptimo lugar, la llevanza de la contabilidad en la sociedad. En cuanto a este indicio, nuestra jurisprudencia ha venido sosteniendo que la llevanza de la contabilidad es una función específica de los administradores y que, por este motivo, el administrador de hecho no podría realizar esta función. No obstante, tal y como establece la STS de 8 de marzo de 2017 (RJ 165/2017), si se demuestra un desplazamiento de la decisión en materia contable del administrador de derecho hacia el administrador de hecho, como sería que este último llevara de la contabilidad, entonces centraríamos la atención en la conducta desarrollada por ese sujeto, $v . g r$., cuando la sociedad ha sido declarada como culpable en un concurso por culpa del administrador de hecho ${ }^{315}$.

Octavo, la profesionalidad sería otro indicio. Según STS de 15 de julio de 1998 (RJ 5717/1998), cuando el administrador de hecho tiene una especial cualificación o la atribución de ciertos conocimientos con titulación profesional, o una cierta experiencia en el sector de la actividad empresarial donde viene actuando ${ }^{316}$. Este requisito será muy relevante en el caso particular de sociedades que vienen ejerciendo sus actividades en mercados financieros, pues las sociedades cotizadas necesitan que sus administradores ostenten conocimientos especiales y adecuados para realizar el ejercicio de sus labores en función de sus normativas específicas $^{317}$.

${ }^{314}$ Cuando la actuación del administrador de hecho produjo la situación de insolvencia de la sociedad, véase RECAMAN GRAÑA, E., "Los deberes y la responsabilidad de los administradores", cit., p. 349.

${ }^{315}$ En este sentido, STS de 8 de marzo de 2017 (RJ 165/2017) que manifiesta que la llevanza de la contabilidad es una obligación que viene legalmente impuesta a los administradores de derecho en los arts. 25 y ss. CCom por lo que su incumplimiento sólo sería imputable al administrador de facto si se declararía la responsabilidad del administrador por su falta de control en la confección de la contabilidad de la empresa.

${ }^{316}$ En este sentido, ver por todos GARRETA SUCH, J. M. A., La diligencia, cit., pp. 46-50. En relación, al comerciante, véase experto STS de 15 de julio de 1998 (RJ 5717/1998) en la que se utiliza la pauta del cuidado del negocio ajeno como si fuera propio.

${ }^{317}$ Explicando que la actuación de los administradores debe venir presidida exclusivamente con el ejercicio diligente derivado de su especialización de conocimientos para los intermediarios 
Al trasladar la concreta exigencia de profesionalidad al administrador de hecho, este constituiría uno de los medios de prueba en los que nos podremos apoyar para demostrar quién es el administrador de hecho en la sociedad, y si ostenta la profesionalidad para administrar, ya que difícilmente podremos calificar a una persona como administrador de hecho si esta no reuniera la capacitación adecuada para realizar las tareas de administración ${ }^{318}$. Aunque, sí que podemos anunciar que la actuación de un administrador de hecho se encuentra muy restringida por las obligaciones legales, y por ello deberemos acudir a indicios más concretos, como pueden ser los relacionados con los actos de la convocatoria de la junta, la redacción de las cuentas anuales o los actos de gestión interna. Conforme a ello, la SAP de Valencia de 27 de septiembre de 1999 (RJ 7586/ 1999) y la STS de 7 de mayo de 2007 (RJ 3405/2007), indican que los actos internos reflejaran que el sujeto indebidamente se inmiscuye en actividades de dirección decidiendo cuestiones muy importantes para el desarrollo de la sociedad ${ }^{319}$.

\section{Indicios particulares de referencia del administrador oculto}

Demostrar que existe un administrador oculto es todavía más problemático porque el art. 236.3 LSC describe otra modalidad de administrador de hecho oculto dirigiendo la sociedad e impartiendo instrucciones a los administradores. Así que su demostración será un reto, porque actúa sin manifestarse y bajo la protección de intermediarios que son los administradores de derecho que asumen sistemáticamente sus órdenes ${ }^{320}$. Demostrar quién es

financieros, véanse SSTS de 20 de enero de 2003 en relación, a la sentencia de 24 de mayo de 1943 (RJ 7574/ 1943).

${ }^{318}$ En este sentido, ver por todos GARRETA SUCH, J. M., La diligencia, cit., pp. 19-26.

${ }^{319}$ En este sentido aquel apoderado que adopta decisiones de gestión con total autonomía, véase SAP de Valencia de 27 de septiembre de 1999 (RJ 7586/1999) califica de administrador de hecho a un apoderado de la sociedad porque existen indicios suficientes de que actuaba como administrador de hecho porque asume la dirección de la sociedad cuando bajo la cobertura de un administrador insolvente y la apariencia de un cargo técnico se esconde un administrador ya que el administrador formal realmente no conoce ni controla el desenvolvimiento usual de la entidad mercantil. Y STS de 7 de mayo de 2007 (RJ 3405/2007).

En el mismo Sentido nuestra doctrina se pronuncia que estos actos son los que determinan cuando un apoderado es administrador de hecho, véase VALPUESTA GASTAMINZA, E., "Equiparación con el administrador de hecho", cit., p. 638.

${ }^{320}$ Este tipo de administrador de hecho oculto como ya es sabido había sido puesto en duda por algunos autores de nuestra doctrina antes de la Ley 31/2014 precisamente porque no aparecía frente a terceros como administrador de la sociedad y por esta razón es más difícil su demostración, entre ellos 
el administrador de hecho en su manifestación oculta resultará posible acudiendo a los indicios que nos servirían para identificarlo en sus numerosas manifestaciones, pero primero debemos descubrir cómo influye en los administradores formales, y para ello determinaremos cuáles son los indicios que clarifican la presencia de un administrador de hecho oculto en función de cuál sea la estructura social donde el administrador oculto se suele presentar.

Seguidamente vamos a detallar los indicios que podemos tomar como referencia para presumir que nos encontramos ante la presencia de un administrador de hecho oculto empezando por el más predominante, el dominio sobre la sociedad ${ }^{321}$. El indicio del dominio por su propia relevancia implica, según SAP de Barcelona de 1 de octubre de 2014 (RJ 310/2014) y SAP de Barcelona de 19 de abril de 2016 (RJ 83/2016), que alguien que ejerce influencia decisiva sobre el administrador de derecho conllevará que este no llega a adoptar decisiones por sí mismo, sino que, más bien se limita a cumplir sus órdenes sin aparecer frente a terceros ${ }^{322}$.

En correlación con el indicio anterior, destacar el indicio de su ocultación que caracteriza a este tipo de administrador de hecho, ya que es el que precisamente demuestra que no se conoce, porque hay un administrador en la sombra detrás de los administradores formales que administra de hecho a la sociedad, hasta tal punto que con su influencia llega sustituir a los administradores de derecho impartiendo decisiones que son cumplidas al pie de la letra por los administradores formales.

El tercer indicio viene constituido por el indicio del tiempo, que es el momento en el que se presenta el administrador de hecho que sería cuando suceden hechos concretos en la sociedad. Para apreciar este indicio vamos a señalar aquel supuesto concreto de un

ALONSO UREBA, A., "Algunas cuestiones en relación con el ámbito subjetivo de la responsabilidad de los administradores (administrador de hecho, administrador oculto y grupos de sociedades)", cit., pp. 88-95; LATORRE CHINER, N., "El concepto de administrador de hecho", cit., pp. 871-872.

${ }^{321}$ En este sentido, véase LÓPEZ CAPELLA, E., "Búsqueda de indicio para la prueba del administrador de hecho", en Probática, Coord. Instituto de Probática y Derecho Probatorio de la Facultad de Derecho ESDE-URL, Iuris, marzo, 2012, pp. 31.

${ }^{322}$ En esta línea considerando al socio mayoritario como administrador de hecho, véase sentencias más recientes, véase SAP de Barcelona de 1 de octubre de 2014 (RJ 310/2014). En esta sentencia se considera como administrador de hecho porque cedió los derechos de un inmueble a la sociedad donde era socio mayoritario y que era insolvente y posteriormente descapitalizo la sociedad; En la misma línea también fue considerado administrador de hecho el socio mayoritario que ordenó realizar la contabilidad y SAP de Barcelona de 19 de abril de 2016 (RJ 83/2016). 
administrador formal cesado porque omitió el deber legal de convocar la junta para disolver la sociedad por perdidas graves en la empresa y, en cambio, el administrador cesado continúa administrando de forma oculta para poder eludir su responsabilidad por obligaciones sociales, o el administrador cesado que continúa administrando la sociedad para que su actividad no quedara inactiva.

El cuarto indicio es el lugar donde actúa este tipo de administrador de hecho de forma oculta, y este indicio se construirá con la ubicación de su despacho en las oficinas de la empresa familiar sin detentar cargo alguno en la sociedad.

Además, los indicios del tiempo y del lugar deberán estar relacionados entre sí, ya que la actuación del administrador de hecho oculto tiene que estar sujeta al principio de causalidad pues, aunque, si bien sus actos son ocultos, deberán de ser el resultado del tiempo y del lugar donde ocurrieron los hechos.

El quinto indicio es el tipo de la sociedad donde el administrador de hecho actúa, que es otro indicio básico para apreciar su presencia ya que este opera básicamente empresas pequeñas y, muy concretamente, en las empresas familiares ${ }^{323}$. En el marco de la empresa familiar el indicio consiste en la relación familiar o de parentesco que une al sujeto al que se le pretende atribuir la condición de administrador de hecho oculto con el derecho ${ }^{324}$. De esta manera, en SAP de Zaragoza de 6 de octubre de 2014 (RJ 242/2014) en relación a los hijos, esposa, padres hermanos u otros parientes como administradores, y se puede constatar que realmente no gestionan la sociedad porque simplemente obedecen las órdenes dictadas por los verdaderos administradores. No obstante, este indicio de la relación familiar se debería complementar con otros indicios más concretos que pueden ser, por citar algunos, que el administrador desconoce prácticamente las actividades de la empresa que a modo de ejemplo señalamos, o que desconoce el pago de créditos pendientes de la sociedad, cuando el administrador formal raramente visita el domicilio social de la sociedad porque tiene trabajo

${ }^{323}$ Véase GARRIDO DE PALMA, V. M., "La operación de acordeón y la sociedad anónima", cit., pp. 1107-1112.

${ }^{324}$ En esta línea de relación familiar o de parentesco, véanse STS de 10 de julio de 1998 (RJ 6116/1998) y SAP de Valencia de 27 de septiembre de 1999 (RJ 2523/1999) con hermanos; de Coruña de 17 de enero de 2000 (RJ 304/2000); de Cuenca de 11 de febrero de 2000 (RJ 922/2000); y en sentencias más recientes SAP de Zaragoza de 6 de octubre de 2014 (RJ 242/2014) entre padre e hija. 
fijo en otra empresa y además detenta un cargo con una profesión que es indiferente al objeto social de la sociedad ${ }^{325}$.

Especial referencia merece el séptimo indicio, que es el grupo de personas que rodean al administrador de hecho oculto. Así, por ejemplo, los trabajadores de la empresa, las personas que giran en torno al administrador de hecho oculto cuando dirige las actividades de gestión externa, como pueden ser los empleados de las entidades de crédito u otros organismos necesarios que no han conocido nunca al administrador formal de la sociedad. En este sentido, aquellas personas de la esfera de la actuación del administrador de hecho oculto servirían para indicar si conocen o no al administrador formal y para indicarnos si los administradores de derecho aceptan las decisiones del administrador de hecho.

Octavo, la aceptación de la sociedad, que se materializará cuando esta asume los actos ejecutados por los administradores como vinculantes para su desarrollo. En este caso aparecerá el administrador de hecho oculto cuando una persona viene ejercitando funciones de administración en la práctica cotidiana porque ostenta el dominio efectivo de la gestión y del gobierno de la sociedad.

Noveno, discordancia entre el administrador todavía inscrito en el Registro Mercantil con el administrador nombrado "de iure", y además junto a ellos también aparece una tercera persona que es la que actúa en calidad de apoderado. En esta situación, según SAP de Baleares de 27 de julio de 1999 (RJ 7586/1999), habría que demostrar mediante el indicio del dominio quién de las tres personas es la que detenta el control, teniendo en cuenta sobre todo quién ejerce la influencia decisiva en la gestión de la sociedad ${ }^{326}$.

${ }^{325}$ Explicando cómo este tipo de administrador de hecho se produce en los ámbitos familiares, véase PERDICES HUETOS, A., "Significado actual de los administradores de hecho", cit., p. 284.

${ }^{326}$ Este supuesto aparece referido de forma expresa en concreto la SAP de Baleares de 27 de julio de 1999 (RJ 7586/1999) donde la administradora de iure era la esposa del apoderado, que con éste formaban la totalidad del accionariado. Por lo tanto, el apoderado no era un simple apoderado o mandatario, que se implica en la gestión de negocios ajenos, sino que más se trataba de intereses propios y particulares, intentando eludir las responsabilidades que pudieran derivarse de su actuación mediante el mecanismo de orillar su nombramiento como administrador y nombrar, sin inscribir en el Registro, a su esposa, mantenido entretanto a un administrador inscrito ajeno a la sociedad. Supuesto distinto es el de los apoderados que no constituyen órgano de la sociedad, y sus relaciones con la misma y frente a terceros, que por regirse por las normas del mandato; esta circunstancia contractual impide que se les pueda considerar a los apoderados como administradores de hecho, es decir como personas que gestionan la sociedad sin tener mandato para ello. 
En el marco de los acreedores de la sociedad, también puede aparecer otro indicio significativo que nos indicaría la presencia de un administrador oculto, que es aquel caso particular de los préstamos concedidos por una entidad a una sociedad en una situación de insolvencia. En este supuesto el indicio del dominio es el que nos conducirá a poder presumir que el oculto es la entidad financiadora de estos préstamos, porque controla a la sociedad deudora dirigiendo la administración con sus órdenes para vigilar el destino de sus créditos y la obtención de sus beneficios como consecuencia de los préstamos que le han sido concedidos $^{327}$.

Merece especial mención la utilización de las sociedades interpuestas para que se presente el administrador de hecho oculto si una dirección externa supera la autonomía de la sociedad interpuesta, o cuando la influencia externa de dominio supone que el administrador de la interpuesta no cumple con sus propias obligaciones legales. En ambos supuestos la demostración del dominio sobre la sociedad interpuesta daría lugar a un indicio que conduciría a poder presumir la presencia del administrador oculto, y cuya manifestación la encontraríamos, según SAP de Zaragoza de 16 de julio de 2015 (RJ 318/2015), cuando los administradores dominan y administran las interpuestas ${ }^{328}$. En este marco, nos adentramos en los indicios de un administrador de hecho oculto en los grupos de sociedades cuando la sociedad matriz se ha reservado la posición de administrador dominante permitiendo que las juntas de las sociedades filiales del grupo nombren a un órgano de administración que va a quedar sometido a su dictado ${ }^{329}$.

No obstante, hay que advertir que la identificación del administrador de hecho oculto no ha sido frecuente en los grupos de sociedades porque, como hemos venido estudiando, la

${ }^{327}$ En este sentido, véanse GARCÍA DE ENTERRIA, J., "La reforma de sociedades de capital", cit., p. 75; PERDICES HUETOS, A., "Significado actual de los administradores de hecho", cit., p. 286.

${ }^{328}$ Sin perjuicio de la ya asentada doctrina del levantamiento del velo, cabe proclamar en este punto la responsabilidad del administrador de hecho para el caso de que el patrimonio social no llegue a cubrir las deudas de la sociedad. Es por ello por lo que la responsabilidad por deudas, al ser una cuestión distinta, exige un plus para que prospere, es decir, se exige daño que puede ser o no una deuda, un nexo causal entre la conducta o actitud por acción u omisión de los administradores como tales y la lesión sufrida por el acreedor social; véase DE ÁNGEL YÁGÜEZ, R., La doctrina del levantamiento del velo, cit., pp. 149-151.

${ }^{329}$ En este sentido se han dictado recientes sentencias en las que se condenan a las sociedades del grupo como administradores de hecho, en concreto SAP de Zaragoza de 16 de julio de 2015 (RJ 318/2015) en la que se indica con la declaración testifical de los trabajadores que recibían ordenes de las empresas el grupo que controlaban a la empresa hasta el punto de que indicaban como tenían que presentar las cuentas anuales. 
aplicación del administrador de hecho en los grupos de sociedad se ha venido tratando más bien como un remedio, un tanto excepcional ${ }^{330}$, con base en que los principios inspiradores de su regulación no toleran la aplicación automáticamente del administrador de hecho, salvo que exista una justificación adecuada que demostrara de forma plena un fraude en la utilización de los grupos de sociedades. Así, que para que surgiera el administrador de hecho oculto en los grupos de sociedades se necesitaría ${ }^{331}$ que se demostrara el indicio de una relación societaria intensa entre las sociedades que integran el grupo, y que suponga la coincidencia de varías circunstancias, por ejemplo, el mismo objeto social y domicilio social y, sobre todo, que existan elementos personales conexionados, como las facultades de administración y de decisión que aboquen a una confusión entre ellas, bordeando así el fraude de ley e implicando abusos que supongan vulneración del principio de autonomía de las sociedades.

${ }^{330}$ Pronunciándose en contra, de la declaración del administrador de hecho en los grupos de sociedades, una vez abalizado el caso concreto, y observar que la matriz solo emitía pautas de viabilidad y supervisar que se cumplieran estas pautas con la finalidad de cumplir con los objetivos de interés público general a diferencia de la intervención administrativa donde se suprime la capacidad decisoria de las empresas intervenida, véase sentencia más recientes como la STS de 8 de abril de 2016 (RJ 224/2016). EMBID IRUJO, J. M., "La responsabilidad de los administradores de la sociedad anónima tras la ley de transparencia”, cit., pp. 2403 y ss.

331 Por consiguiente, no puede reconocerse esa independencia de personalidades cuando, de conformidad con el artículo 6.4 del CC relativo al fraude de ley, se advierte que la creación de entidades mercantiles constituye una simple ficción determinante de un auténtico fraude de ley, de tal manera que, al levantar el velo, se descubre la inconsistencia de las sociedades como personas jurídicas. En este sentido la doctrina BOLDÓ RODA, M.C., "Levantamiento del velo y persona jurídica en el Derecho privado español”, $R d S$, Aranzadi, 1997, p. 27; HURTADO COBLES, J., La doctrina del levantamiento del velo societario en España e Hispanoamérica, Ed. Atelier, 2008, pp. 44 y ss., recordando que se parte de un conflicto entre seguridad jurídica y justicia, valores consagrados en la Constitución arts. 1.1 y 9.3 CE, en la cual, se ha decidido prudencialmente, según los casos y circunstancias, por aplicar por vía de equidad y el principio de buena fe art. $7.1 \mathrm{del} \mathrm{CC}$, la tesis y práctica de penetrar en el substratum personal de las entidades o sociedades a las que la Ley confiere personalidad jurídica propia "con el fin de evitar que, a la sombra de esta ficción legal y respetable, se puedan perjudicar los intereses privados y públicos, o bien puedan ser utilizadas como camino de fraude, se trata pues de permitir que los jueces puedan levantar el velo jurídico y penetrar en el interior de las personas jurídicas cuando sea preciso para evitar el abuso de la independencia de las personas jurídicas". 


\title{
CAPÍTULO SEGUNDO
}

\author{
LA APLICACIÓN DE LOS DEBERES DE LOS
}

ADMINISTRADORES AL ADMINISTRADOR DE HECHO 


\section{DELIMITACIÓN PREVIA}

La Ley 31/2014 supuso un avance en la regulación del administrador de hecho porque el art. 236.3 LSC sometió a las personas que se conceptuaban como tal a cumplir con los deberes de los administradores. Sin embargo, obvió determinar cómo pueden cumplir con tales deberes mereciendo esta consideración, en especial, respecto de los deberes legales por su condición de ser simplemente un hecho ${ }^{332}$.

En realidad, esta Ley mantuvo la responsabilidad del administrador de hecho tal y como fue reconocida por la Ley de Transparencia, aunque aportó una definición del mismo más precisa al recoger aquellas posturas contradictorias que hasta esa fecha nuestra doctrina había venido elaborado ${ }^{333}$. Así que por lo que a nosotros atañe dicha Ley supuso un hito legislativo, ya que modificó sustancialmente los deberes que el administrador de hecho debería cumplir ${ }^{334}$. De esta manera, el administrador de hecho se convirtió en un instrumento que serviría para que cualquier persona que por su actuación hubiera intervenido en asuntos de administración, debía cumplir con todos los deberes de los administradores con el mismo nivel de exigencia que se requeriría a los administradores formales ${ }^{335}$. No obstante, consideramos que antes de exigir el cumplimiento de los deberes de los administradores, debemos dilucidar en qué medida el administrador de hecho podría ejercerlos si carece de legitimación formal para cumplirlos en algunos $\operatorname{casos}^{336}$.

A raíz de este planteamiento la cuestión a dilucidar es en qué medida el administrador de hecho tiene la posibilidad de poder cumplir con tales deberes. Al respecto argumentamos

\footnotetext{
${ }^{332} \mathrm{El}$ contenido de los deberes de los administradores con la reforma se refiere a los administradores en general y el administrador de hecho solo aparece en los presupuestos de la responsabilidad y como una extensión subjetiva de la responsabilidad de los administradores, véase MATEU DE ROS CEREZO, R., Práctica de gobierno corporativo, cit., pp. 55-89.

${ }^{333}$ Véase el Preámbulo Ley 31/2014, de 3 de diciembre, por la que se modifica la ley de sociedades de capital para la mejora del gobierno corporativo.

${ }^{334}$ Sobre los fines del gobierno corporativo, ALFONSO SÁNCHEZ, R., "Obligaciones básicas del deber de lealtad: art. 228”, en AA.VV., Régimen de deberes, cit., pp. 187-234.

${ }^{335}$ La función instrumental del concepto de administrador de hecho ha servido para reforzar más el cumplimiento de los deberes, véase RODRÍGUEZ DE LAS HERAS BALLELL, T., "Requisitos para ser administrador", cit., pp. 750-753.

${ }^{336}$ Véase HERNADO CEBRIÁ, L., "Presupuestos del deber de lealtad: artículo 227.1", cit., pp. 152153.
} 
que, con la definición del administrador de hecho centrada en su forma de actuar, solo cabría que nos planteáramos la extensión de los deberes de los administradores al supuesto concreto del administrador de hecho en su manifestación oculta, y para fundamentar este argumento nos apoyamos en el hecho de que los administradores formales son los que realizan todas las obligaciones que comprenden los deberes conforme a las instrucciones del administrador de hecho oculto. Por el contrario, el administrador de hecho notorio, el que actúa bajo otro título, simplemente se limita a inmiscuirse en competencias que no le son propias, pues estos sujetos no han sido designados por la sociedad formalmente para realizar tales funciones. Para llegar a esta consideración seguimos a aquel sector doctrinal que considera que el administrador de hecho oculto actúa administrando la sociedad, pero dirigiendo a los de derecho que cumplen de forma sistemática sus instrucciones sin objeción alguna.

En este capítulo analizaremos si la amplia gama de sujetos que engloba el concepto de administrador de hecho en la LSC podrá cumplir con los deberes de los administradores atendiendo a sus posibilidades de actuación, para después poder exigirle la responsabilidad, según estudiaremos en el capítulo tercero. A tal fin, tendremos en cuenta, en primer lugar, el tipo estructural de sociedad donde actúa, pues sus posibilidades de actuación serán distintas según actúe en una SA de grandes dimensiones, en una sociedad cotizada, en una SRL o en una empresa familiar. En segundo lugar, la forma de organización que adopte el órgano de administración y, por último, el deber de diligencia y el de lealtad para poder averiguar en qué medida tuvo posibilidades de cumplirlos, así como otros deberes legales como la convocatoria de la junta general $^{337}$.

\footnotetext{
${ }^{337}$ Los deberes de los administradores son el núcleo central de gobierno corporativo movimiento que surgió para poder controlar las actuaciones de los administradores y controlar los excesos de poder en las grandes sociedades, véanse DÍAZ RUÍZ, E, "El informe anual de gobierno corporativo (art. 540 LSC)", en AA.VV., Junta general, cit., pp. 1039-1045 y pp. 1057-1063; ESTEBAN VELASCO, G., "¿Una nueva manera de entender e impulsar la evolución del sistema de gobierno de las sociedades cotizadas?", en AA.VV., El gobierno de las sociedades cotizadas, cit., pp. 25-51, p. 30-33. El marco de gobierno se establece con el fin de promover el uso eficiente de los recursos y, en igual medida, poder exigir que se rindan las cuentas por la administración de esos recursos. Y su propósito es lograr el mayor grado de coordinación entre los intereses de los individuos y las empresas y también sus propietarios y los administradores para poder adoptar las normas de gestión aceptadas a nivel internacional, véase PINTO, A., Y VISENTINI, G., The legal basis of corporate governance in publicity held corporations, Ed. Kluwer law, United Kingdon, 1998. En Estados Unidos la regulación de la federal de Public Company Accounting Reform and Iinvestor Protectión Act, de 29 de julio de 2002, también conocida como Sabanes-Oxley Act; véase SIGNES DE MESA, J. I., "La sección 404 de la Sabanes-Oxley Act y los controles internos financieros: un balance tras de años de aplicación", $R D B B$, núm. 28, octubre-diciembre, 2012, pp. 161-182.
} 


\section{EL DEBER DE DILIGENCIA Y EL DEBER DE LEALTAD}

\section{El deber de diligencia}

Los precedentes legislativos demuestran que, en un principio, para regular el comportamiento de los administradores no se establecieron reglas relativas a actitudes o valores morales como pueden ser la diligencia, la fidelidad o la lealtad; así, el CCom se limitaba a regular sus conductas bajo las reglas contenidas en el contrato del mandato, de modo que sus conductas eran meros quehaceres que ligaban al administrador con la sociedad mediante un contrato de mandato que no llegaba a incidir en las conductas para desempeñar sus funciones. De ahí que no regulaban concretamente el contenido de sus obligaciones.

Tampoco la legislación societaria del siglo pasado se ocupó del contenido de los deberes ni realizó una revisión sistemática de sus obligaciones cuando se promulgó la LSA de 1951, salvo aquella proclamación genérica de la responsabilidad de los administradores que se contenía en el art. 79. 1 LSA de 1951, “Los administradores desempeñarán su cargo con la diligencia de un ordenado empresario y representante leal"338.

Posteriormente, un paso adelante en materia de deberes fue la reforma parcial de la Ley 19/1989, de 25 de julio, para que nuestro sistema societario se pudiera adaptar a las Directivas de la CEE que reformaron el art. 79 TRLSA, "Los administradores desempeñarán su cargo con la diligencia de un ordenado empresario y de un representante legal. Deberán guardar secreto sobre la información de carácter confidencial aun después de cesar en sus funciones". Aunque añadiendo la obligación de guardar secreto, no obstante, se siguieron las líneas anteriores, porque su actuación gestora se determinaba desde la óptica del daño causado.

Paralelamente, la Comisión Olivencia sugería más normas de conducta para que los administradores las tuvieran en cuenta a la hora de adoptar sus acuerdos. En concreto, para cumplir con el deber de diligencia proponía separar las consecuencias de las decisiones adoptadas por los miembros del Consejo de administración que habían sido adoptadas con el

\footnotetext{
${ }^{338}$ Véase URÍA GONZÁLEZ, R., Derecho mercantil, Ed. Cívitas, Madrid, 2002, pp. 223-224.
} 
debido estudio y asesoramiento, de aquellas otras que habían sido adoptadas por los consejeros en conflicto con los intereses de la sociedad.

Con la Ley de Transparencia ${ }^{339}$ se desarrolló el actual régimen de deberes, aunque hubo otras reformas parciales como la operada por la Ley Financiera de 2002 que supuso la integración del comité de auditoría como un mecanismo de control contra las actuaciones de los administradores ${ }^{340}$. A tal fin, se estableció que la persona que actuara como administrador de hecho debía cumplir con la diligencia de un ordenado comerciante y un representante leal, y que debería informarse diligentemente de la marcha de la sociedad ${ }^{341}$. Sin embargo, la extensión de todos los deberes al administrador de hecho ha sido una constante polémica en la doctrina desde que la Ley de Transparencia introdujo al administrador de hecho en el art. 133.2 $\mathrm{LSA}^{342}$.

No obstante, debido al carácter abstracto que impregnaba el modelo de actuar de un ordenado empresario, que fue reflejado en la LSC de 2010 junto con el deber de informarse de la marcha de la sociedad, se continuó dibujando este deber de diligencia bajo el concepto jurídico indeterminado de un ordenado empresario, ya que la Ley no especificaba tales comportamientos en el art. 225.1 LSC antes de las reformas introducidas por la Ley 31/2014.

En definitiva, se instauró un deber general de administrar que funcionaba como cláusula general, incluso para los supuestos donde las obligaciones del administrador se encontraban

${ }^{339}$ La Ley de Transparencia introdujo el deber de diligencia separado del deber de secreto, véase JUSTE MENCÍA, F., Y IGARTUA ARREGUI, J., "Deberes de los administradores (reforma de la LSA por la Ley de Transparencia)", cit., pp. 75-89.

${ }^{340}$ Entre las medidas para combatir y explicar las causas de las crisis económicas en las sociedades por el exceso de poder se encontraban las recomendaciones del movimiento del gobierno corporativo, véase MATEUS ROS CEREZO, R., El Código unificado, cit., pp. 77-81; SERRANO CAÑAS, J. M., El conflicto de intereses en la administración de sociedades mercantiles, Publicaciones del Real Colegio de España, Bolonia, 2008, pp. 86-89.

${ }^{341}$ En torno a las reformas de la Ley de Transparencia en materia de deberes, véase LATORRE CHINER, N., "El concepto de administrador de hecho", cit., p. 854.

${ }^{342}$ Esta corriente doctrinal ya se anticipaba en este sentido de la no sujeción del administrador de hecho a tener que cumplir con todos los deberes que competen al órgano de administración, véase LATORRE CHINER, N., "El concepto de administrador de hecho", cit., p. 894-895. 
señaladas de forma expresa en los estatutos. Por este motivo, deberemos responder en primer lugar a la siguiente pregunta: ¿qué entendemos por diligencia de un ordenado empresario? ${ }^{343}$.

Podríamos decir a priori que el concepto de un ordenado empresario es el modelo de conducta de una persona que no arriesga en operaciones descabelladas, porque antes de decidir realiza un cálculo adecuado de sus posibilidades de actuación para la búsqueda de un resultado previsto. Esto es, deberemos entenderla en el ámbito societario como patrón de conducta general que se complementa con el deber de actuar de buena fe y lealtad ${ }^{344}$. En este sentido, diversas han sido las aproximaciones por parte de la doctrina para establecer una definición de la diligencia, aunque el criterio sostenido por la doctrina mayoritaria es el que se refiere a una actuación planificada, ordenada y dirigida a la obtención del fin social ${ }^{345}$.

Al tiempo, la falta de determinación de las actuaciones del ordenado empresario nos obliga a tener que adentrarnos en las concretas manifestaciones del deber general de diligencia para concretar en qué medida el administrador de hecho puede cumplir con este deber cuando ejerza funciones de un administrador formalmente nombrado por la sociedad. Hay que recordar que, tradicionalmente, ha existido una falta de delimitación legal del concepto de diligencia y, por este motivo, nuestros tribunales se encontraban con la dificultad de aplicar el modelo de conducta debida a un administrador societario ${ }^{346}$. Para resolver esta cuestión acudían a las recomendaciones recogidas en los CUBG sobre actuaciones diligentes de los administradores y a una figura procedente del derecho norteamericano llamada la regla

343 La razón del mantenimiento del deber de diligencia como clausula general estribaba fundamentalmente en la necesidad de que el administrador tenía que adaptarse a las circunstancias de cada tipo de sociedad., véase RODRÍGUEZ ARTIGAS, F., "El deber de diligencia", en AA.VV., El gobierno de las sociedades cotizadas, cit., pp. 419-444; HERNANDO CEBRIÁ, L., "El deber de diligencia: artículo 225", en AA.VV., Régimen de deberes, cit., pp. 59-98.

344 Véanse FERNÁNDEZ DE LA GÁNDARA, 1., Derecho de Sociedades, cit., p. 737-7388; GARRETA SUCH, J. M., La diligencia, cit., pp. 9 y ss., cuando dice: "La imposición a los administradores de un estándar de diligencia típica y objetiva la de un ordenado empresariopresupone un modelo de conducta cuya determinación solo es posible con criterios flexibles y al mismo tiempo objetivos". HERNANDO CEBRIÁ, L., El deber de diligente administración en el marco de los deberes de los administradores sociales. La Regla del buen juicio empresarial, Ed. Marcial Pons, Madrid, 2009, p. 120.

${ }^{345}$ En este sentido lo manifiesta GARRETA SUCH, J. M., La diligencia, cit., pp. 50-60.

346 Véase MUÑOZ GARCÍA, A., "La disponibilidad, de lege lata, el deber de diligencia de los administradores", en AA.VV., Estudios sobre órganos de las sociedades de capital, cit., pp. 10231046. 
del buen criterio empresarial, la Business Judgment Rule ${ }^{347}$. Esta regla se apoya en criterios de valoración de conductas diligentes y servían para que los jueces pudieran resolver las cuestiones que versaban sobre el incumplimiento del deber general de diligencia en el caso concreto que se enjuiciaba ${ }^{348}$.

Llegados a este punto, el problema consistía en determinar cómo debía entenderse que una actuación realizada por el administrador era diligente. Al respecto, la Comisión Olivencia de 1998 formuló toda una serie de recomendaciones precisas y ponderadas para concretar las manifestaciones diligentes de los administradores ${ }^{349}$ que se centraban en que las tareas de organización deberían ser precisas, para así poner en marcha a la sociedad con un procedimiento previo y con información suficiente y dedicación profesional ${ }^{350}$. También el Informe Aldama contemplaba las pautas de una conducta diligente $\mathrm{y}$, pese a su escasa aplicación por su falta de regulación legal, significaron una oportunidad para protegerse de las demandas que se activaban por la falta de una actuación diligente de los administradores. Así, estas pautas se concentraban, en primer lugar, en que los administradores debían dedicar su tiempo para recapitular información suficiente, de forma continua y con esfuerzo, solicitando la colaboración o la asistencia oportuna. En segundo lugar, que las tareas de administración debían distribuirse participando activamente todos los miembros del órgano de administración

${ }^{347}$ Con mayor detalle sobre los presupuestos de esta regla, véanse EMBID IRUJO, J. M., "La protección de la discrecionalidad empresarial”, en AA.VV., Régimen de deberes, cit., pp. 105-131; HERNANDO CEBRIÁ, L., El deber de diligente administración en el marco de los deberes de los administradores sociales. La Regla del buen juicio empresarial, cit., p. 120.

348 Las consideraciones de nuestros tribunales establecían que "correspondía a los empresarios la adopción de las decisiones empresariales, acertadas o no, sin que el examen del acierto intrínseco en sus aspectos económicos pueda ser fiscalizado por los Tribunales ya que "escapa por al control de la Jurisdicción". Pese a lo cual se sostuvo en la STS de 6 de octubre de 2007 (RJ 569/2007): "la trascendencia económica que en las sociedades capitalistas tiene el correcto desarrollo de la vida interna".

349 Comisión Olivencia, creada por el Gobierno español en 1997, elaborando un informe hecho Público en febrero de 1998, que preveía la incorporación de buena parte de las prácticas de buen gobierno a las empresas cotizadas y en el punto 8.1. se aconsejaba "que el carácter abstracto de la conducta de diligencia de un ordenado empresario y de un representante legal hacia recomendable que en las normas internas de la compañía debería recoger las principales obligaciones que dimanan de los deberes generales de diligencia y de lealtad, con el fin de estimular que los consejeros tomen conciencia de los compromisos que contraen al asumir el cargo y de facilitar la valoración de su actuación".

${ }^{350} \mathrm{El}$ contenido de las recomendaciones en los CUBG era una de las formas de poder concretar las pautas de conducta del deber de diligencia, véanse. ALONSO UREBA, A., "Mejoras en la estructura y calidad de las decisiones del Consejo" en AA.VV., Cuaderno de derecho para ingenieros, cit., pp. 1330; MATEU DE ROS CEREZO, R., El código unificado, cit., pp. .34 y ss. 
expresando opiniones y solicitando la concurrencia de todos los consejeros para adoptar la decisión más favorable en defensa del interés social y, si no pudieran asistir por causa justificada, que sus criterios se impartieran al consejero que les representara. En tercer lugar, debían de oponerse a los acuerdos que fueran contrarios a la Ley, a los estatutos o al interés social dejando constancia de su oposición. En cuarto lugar, que debían incluir todos los extremos que considerarán convenientes de acuerdo con la Ley y los estatutos sociales. Por último, que debían solicitar la información necesaria para realizar un juicio objetivo e independiente sobre el funcionamiento de la sociedad obteniendo la información necesaria para cumplir su misión. De ahí que estas conductas garantizaban el ejercicio diligente del administrador con base en su profesionalidad, su dedicación y la obtención previa de información necesaria para adoptar las decisiones con buena fe, racionalidad y previsibilidad.

En esta misma línea, el Código Conthe también concretaba las pautas de conducta del deber general de diligencia con el fin de que fueran acogidas por los administradores en su recomendación octava, aconsejando que el Consejo asumiera la misión de aprobar las políticas y estrategias de la sociedad, así como la organización que fuera precisa para su puesta en práctica $^{351}$. Sin embargo, el problema que subyacía era el desempeño del cargo con diligencia, por el concepto jurídico indeterminado de "un ordenado empresario" que, como elemento esencial de este deber, encontraba su reflejo en el art. 225 LSC, ya que al ser tan general resultaba insuficiente para poder demostrar el incumplimiento del deber de diligencia por los administradores ${ }^{352}$.

Al tiempo, la Ley 31/2014 precisó el contenido del deber general de diligencia requiriendo que los administradores reflejaran la evolución real de la empresa mediante los

${ }^{351}$ En el Informe Conthe consta en la recomendación octava, que" el consejo se reserve la competencia de aprobar: las políticas y estrategias generales de la sociedad, y en particular: i) El plan estratégico o de negocio y los objetivos de gestión y presupuesto anuales; ii) La política de inversiones y financiación; iii) la definición de la estructura del grupo de sociedades; iv) la política de gobierno corporativo; v) la política de responsabilidad social corporativa; vi) la política de retribuciones y evaluación del desempeño de altos directivos; viii) la política de control y gestión de riesgos y el seguimiento periódico de los sistemas internos de información y control; viii) la política de dividendos, así como la auto cartera y, en especial, sus límites".

${ }^{352} \mathrm{El}$ concepto jurídico indeterminado de "un ordenado empresario" se instauró como el contenido del deber de diligencia, aunque significaba tener la profesionalidad adecuada, véanse ALFÁRO ÁGUILA-REAL, J., "Articulo. 225. Deber general de diligencia", en AA.VV., Comentarios de la reforma, cit.., pp. 313-356, pp. 319-320; FERNÁNDEZ DE LA GÁNDARA, F., "Profesionalidad y diligencia constituyen dos caras de una misma moneda", $R d S$, 2010, p. 738; GARCÍA DE ENTERRÍA, J., "Los deberes de conducta de los administradores. Deber de diligencia y lealtad", cit., p. 62; GARRETA SUCH, J. M., La diligencia, cit., pp. 46 y ss. 
informes de sostenibilidad, y se concretó en que las actuaciones de los administradores deberían estar correctamente alineadas con el interés de la sociedad ${ }^{353}$. Así pues, el deber de diligencia se reflejó de forma particular en el art. 225. 2 LSC, por la naturaleza del cargo asignado y por las funciones atribuidas a cada administrador. Este nuevo cambio significó que el nivel de exigencia de estos deberes se modularía en función de estas formas de concreción, por influencia del gobierno corporativo. Además, en este mismo precepto se recogieron como obligaciones específicas, la dedicación adecuada, la adopción de las medidas precisas para la buena dirección y el control de la sociedad. El deber paradigmático de los administradores se concretó en el art. 225.3 LSC con la obligación de que, "Los administradores tienen el deber de exigir información a la sociedad y el derecho de recabar la información” Sin embargo, estas referencias no significaron que el deber de diligencia se convirtiera en una cláusula concreta, sino que, al contrario, se mantuvo como cláusula abstracta por ese carácter discrecional que impregnaba el actuar con la debida diligencia ${ }^{354}$.

No obstante, la concreción de este deber se logró con la discrecionalidad empresarial que se reguló en el art. 226 LSC. Esta regla reconoció, por primera vez, en nuestra legislación societaria el principio de la llamada Business Jugdment Rule, aunque solo se debería emplear para las decisiones estratégicas y de negocio adoptadas con un procedimiento calculado razonablemente, con buena fe, sin interés personal y con información. Su exigencia se sumaba a una gestión responsable en los intereses que habían sido confiados a los administradores, aunque los resultados no fueran beneficiosos o las decisiones resultaran erróneas.

Al trasladarnos a nuestro objeto de estudio, de nuevo se nos plantea la cuestión de cómo el administrador de hecho cumpliría con el deber general de diligencia en función de la

${ }^{353}$ Con este fin "las empresas desarrolla sus respectivos programas de responsabilidad social, que abarcan diferentes aspectos, entre los que destacan: La responsabilidad hacia el medio ambiente, la satisfacción de los clientes, la creación de valor para los accionistas como por ej. iniciativas que fomentan la participación de estos, más allá de la legislación en cada momento, las necesidades y aspiraciones de los empleados como formación continuada, direccionamiento del talento, la relación con proveedores y colaboradores y los efectos sobre las comunidades. los entornos en los que la empresa está presente". Así, "su objetivo final es apoyar el desarrollo de las prácticas responsables de las organizaciones públicas y privadas con el fin de fomentan las necesidades de los empleados, la relación con proveedores y colaboradores" véase EMBID IRUJO, J. M., "La responsabilidad social corporativa ante el derecho mercantil", Cuadernos de Derecho y Comercio, núm. 24, 2004, pp. 11-44.

${ }^{354}$ Para la concreción del deber de diligencia y su modulación, véase LLEBOT MAJÓ, J. O., "El deber general de diligencia (art. 225.1 LSC)", en AA.VV., Junta General, cit., pp. 317-344. La diligencia queda bastante desdibujada frente al deber de lealtad en la LSC ya que con una razonable diligencia se presume que el administrador ha actuado con diligencia, véase MATEU DE ROS CEREZO, R., Práctica de Gobierno Corporativo, cit., pp. 55-56. 
naturaleza del cargo y de las funciones atribuidas, cuando esta figura por su modo de actuar no tiene un cargo asignado en la sociedad. Al ser el objeto de estudio la responsabilidad del administrador de hecho debemos abordar, en primer lugar, el estudio del deber general de la diligencia.

\subsection{El deber de diligencia como cláusula abstracta y su cumplimiento por el administrador de hecho en función de los tipos de sociedades y de los modelos de organización}

El art. 225.1 LSC conforma el contenido del deber de diligencia con la cláusula abstracta de un ordenado empresario dependiendo, en gran medida, de la naturaleza del cargo y de la atribución de funciones a cada administrado. La base del mantenimiento del deber de diligencia, como cláusula abstracta, estriba en que la diligencia debe de tener un estándar abierto que se pueda ajustar a las circunstancias concretas de cada sociedad para que el administrador realice fácilmente sus tareas en función de los medios de que disponga. Así, el administrador diligente tiene que ser capaz de adaptarse a la sociedad que administra en función de su objeto social, tamaño y de las concretas circunstancias concurrentes ${ }^{355}$.

Por tanto, la naturaleza del deber de diligencia impide que se concreten pautas específicas de conducta de una forma pormenorizada y, por este motivo, para determinar la diligencia exigible al administrador de hecho debemos de tener en cuenta las múltiples actividades que engendran los negocios que se deben decidir en función de la aleatoria actividad interna de cada sociedad y de los medios de que disponga. Por su falta de facultades, el administrador de hecho deberá ajustarse a las circunstancias de cada sociedad y al modelo concreto de administración adoptado por la sociedad, como su tipo estructural, tamaño y objeto social ${ }^{356}$.

355 Véase GARCÍA MALDONIZ, M., "Inconcreción del deber de diligente administración, disposición del régimen de responsabilidad e inclusión de la regla de la discrecionalidad empresarial (artículo 225 y 226 de la ley de sociedades de capital", en AA.VV., Gobierno corporativo, cit., pp. 355-410; RODRÍGUEZ ARTIGAS, F., "EL deber de diligencia”, cit., pp. 435-439.

${ }^{356}$ La aplicación del deber de diligencia y su adaptación a cada tipo social, véase GARRIGUES DÍAZ-CAÑAVATE, J. Y URÍA GONZALEZ, R., Comentarios a la ley de sociedades anónimas, cit., pp. 159-160. 
Por otro lado, en la LSC no hay un régimen específico sobre el administrador de hecho, salvo en materia de extensión de la responsabilidad pues el legislador, aunque ofreció un tratamiento de igualdad entre el administrador de hecho y el de derecho, configuró al primero por su modo de actuar y, por esta razón, habrá que atender a los medios de que disponga por su falta de designación expresa de la sociedad para poder ejercer los deberes de los administradores, tal y como se ha establecido en el art. 236.3 LSC. A tal efecto, debemos examinar los distintos modelos de administración y el tipo estructural de cada sociedad para valorar en qué medida tuvo posibilidad de cumplir con el deber de diligencia por la imposibilidad competencial para desempeñar las funciones de los administradores $\mathrm{y}$, en particular, en las sociedades cotizadas con su manifestación oculta ${ }^{357}$.

Recordemos que en el art. 124.1 Reglamento del Registro Mercantil se dispone que el modo de organizase la administración deberá venir especificado en los estatutos, y que el art. 210 LSC articula las distintas formas de organizar la administración de la sociedad en función del tipo social concreto. De ahí que si se tratara de SA cuando la administración se ha conferido a dos administradores estos deberán actuar mancomunadamente; en cambio, si se ha conferido a tres administradores deberá constituirse con consejo de administración ${ }^{358}$, y si se tratará de SRL, en el art. 210.3 LSC no se dispone obligación para estructurar un modelo de organización de la administración ${ }^{359}$.

Por su parte, el nuevo artículo 529 bis LSC $^{360}$ dispone que las sociedades cotizadas deberán de adoptar el modelo de organización de consejo de administración, aunque la adopción de este modelo ya era práctica muy consolidada, porque el consejo conlleva un mejor control y vigilancia entre sus miembros debido a las distintas asignaciones de cargos y por las delegaciones que se otorgan a título individual o al conjunto de todos sus miembros,

${ }^{357}$ Explicando las tres responsabilidades del consejo de las sociedades cotizadas que son orientar la política de la compañía, controlar las instancias de gestión y servir de enlace con los accionistas, véase RODRÍGUEZ ARTIGAS, F., "El deber de diligencia”, cit., pp. 435.

${ }^{358}$ De acuerdo con lo dispuesto en el art. 124.d) Reglamento del Registro Mercantil y en el art. 210.3 LSC.

${ }^{359}$ En esta materia, véase RUANO BORRELLA, J. P., "Registro mercantil”, en AA.VV., Hacía un nuevo código mercantil, cit., pp. 115-122.

${ }^{360}$ Que se introdujo por la Ley 31/2014. 
aunque con el incremento de facultades indelegables se ha logrado que retuviera competencias fundamentales para deliberar las decisiones estratégicas ${ }^{361}$.

Por otro lado, respecto a las SA cotizadas y no cotizadas, las recomendaciones desarrolladas en el CUBG de 2006 adelantaban un nuevo modelo de gobierno por la vía de la autorregulación, que venía a establecer una nueva configuración competencial y funcional del consejo de administración, que podría servir para revisar el sistema monista y configurar un nuevo consejo de administración que fuera esencialmente supervisor con el fin de controlar a la dirección permanente y para que no se atribuyera excesivo poder a los consejeros ejecutivos y a los altos directivos. No obstante, es cierto que el modelo de organización de las sociedades cotizadas actualmente ha evolucionado notablemente acercándose a aquellos modelos dualistas ${ }^{362}$.

La elección del mejor modelo de administración para actuar el administrador de hecho dependerá de la concurrencia de una serie de factores que influirán notablemente en sus posibilidades de cumplir los deberes de los administradores ${ }^{363}$. El primer factor viene constituido por el tipo estructural de la sociedad, el segundo, por el accionariado de cada sociedad que al mismo tiempo se encuentra relacionado con el tercer factor que se halla integrado por los mecanismos de control y, por último, con sus facultades de actuación en cada sociedad.

Por ello vamos a recurrir a nuestra mejor doctrina para clasificar a las sociedades en tres $\operatorname{tipos}^{364}$. La primera, calificada de cerrada o pequeña es la formada por un número reducido de

361 En esta materia sobre las amplias facultades indelegables, véase FERNÁNDEZ DE LA GÁNDARA, "Políticas decisiones relevantes en materia de gestión/ dirección: prohibición de delegación de facultad", cit., pp. 200-210.

${ }^{362}$ Véanse ALONSO UREBA, A., "Hacia un modelo monista revisado de administración de las SA cotizada como opción al modelo dualista en la modernización del derecho de sociedades de capital en España", en AA.VV., Cuestiones pendientes de reforma (Dir. ALONSO UREBA Y ESTEBAN VELASCO), t. I, Madrid, 2011, pp. 561-639; UNCETA LABORDA, M., "La configuración del órgano de administración: el sistema monista y el sistema dual. Especial referencia al régimen de la sociedad anónima europea”, en AA.VV., Gobierno corporativo, cit., p. 165-205.

${ }^{363}$ La concepción de un órgano de administración en las sociedades de estructura corporativa y los titulares de ese órgano los administradores y sus diversas formas de organización dependen del tipo de cada sociedad, véase LAVILLA RUBIRA, J. J., “Órgano”, en Enc. Jur. Básica, Madrid, 1995.

364 Explicando la clasificación tripartita desde la dogmática norteamericana, véase VIERA GONZÁLEZ, A. J., "Las sociedades de capital cerradas", RdS, núm. 18, 2002, pp. 37-41. 
socios que normalmente tienen entre sí relaciones de profunda amistad o vinculación familiar. La segunda, más grande y calificada de abierta, se integra por un número de socios considerable que ejercitan de forma activa su condición impartiendo instrucciones al órgano de administración. Y, por último, la sociedad bursátil que se caracteriza por un accionariado amplio y disperso donde es latente un dominio de los administradores sobre un accionariado al que solo se interesa el resultado de sus dividendos. En este caso particular de las sociedades complejas, denominadas sociedades de grandes empresas, necesitan del apoyo de una dirección integrada dentro del órgano de administración que se manifiesta mediante la realización de contratos de alta dirección, managment o ejecutivos que podrían ser calificados como administradores de hecho por delegación de facultades del órgano de administración a favor de estos directivos que adoptan decisiones importantes de la sociedad y, en este contexto, sí cabría que actuara un administrador de hecho con notables posibilidades para cumplir los deberes de los administradores ${ }^{365}$.

Hay que advertir que resulta difícil que exista un administrador de hecho en las sociedades cotizadas por varios factores. El primero, por la sujeción a las estrictas normas del mercado de valores, el segundo, por su propio funcionamiento interno regido por las recomendaciones de los CUBG, y, por último, por las diferentes atribuciones entre los administradores que lo integran. Por estos motivos consideramos que el modelo de organización con forma de Consejo dificultará la actuación del administrador de hecho porque por su modo de actuar se encontraría limitado para ello. En cambio, como la atribución de funciones concretas se desvanece en las sociedades pequeñas estructuradas, en la práctica, con uno o dos administradores mancomunados o solidarios, sí sería posible que el administrador de hecho tuviera posibilidades para cumplir los deberes de los administradores ${ }^{366}$.

${ }^{365}$ Altos ejecutivos, junto al órgano de administración, mantienen la supremacía jerárquica en la sociedad, SÁNCHEZ CALERO, F., Los administradores, cit., pp. 44 y ss.

${ }^{366}$ En torno a estas cuestiones, véase ESCRIBANO GAMIR, M. C., "Humano, demasiado humano: el enriquecimiento injusto del administrador desleal", en AA.VV., Estudios sobre órganos de las sociedades de capital, cit., pp. 1079-1099. Sobre las funciones atribuidas a los administradores. GARCÍA DE ENTERRÍA, J., "Los deberes de conducta de los administradores" cit., pp. 64-65. Explicando la distribución de las funciones entre los administradores GARCÍA MALDONIZ, M., "Inconcreción del deber de diligente administración", cit., p. 371. La consideración de las posibilidades de actuación de un administrador de hecho dependiendo del tipo de sociedad LATORRE CHINER, N., El concepto de administrador de hecho, cit., pp. 895-896. Sobre la mejor aplicación de la distribución de las funciones de los administradores en las grandes sociedades y su disminución en pequeñas sociedades QUIJANO GONZÁLEZ, J., "Responsabilidad de los consejeros", en AA.VV., El gobierno de las sociedades cotizadas, cit., pp. 537-592. 
El segundo factor que nos permitirá distinguir en qué medida el administrador de hecho podría actuar para cumplir los deberes de los administradores, es la diversidad del accionariado de cada sociedad, el cual se encuentra relacionado con el tercer factor, integrado por los mecanismos de control contra los administradores y, sobre todo, para una posible actuación del administrador de hecho por falta de control de los accionistas del órgano de administración ${ }^{367}$. En este sentido, puede distinguirse, por una parte, entre una SA no cotizada con un capital concentrado en un grupo de socios que mantienen el control y con ello la posibilidad de la actuación del administrador del hecho como un accionista mayoritario para realizar el ejercicio de los deberes de los administradores y, por otra, una SA con accionariado disperso donde los administradores detentan el poder, siendo escasa las posibilidades de actuación del administrador de hecho en su manifestación de accionista mayoritario para influir en las decisiones de los administradores ${ }^{368}$.

El tercer factor son los mecanismos de control sobre la actuación de los administradores, que serán variables al venir predeterminados por el grado de control que los accionistas ostentan en la sociedad, y sus efectos también serán distintos en función del tipo estructural de la sociedad. Los mecanismos de control operan en las sociedades cerradas, donde los socios se encuentran vinculados con los administradores por acuerdos para sociales que, en la mayoría de las ocasiones, se sustentan por lazos familiares, de profunda amistad o de amplia confianza. En estas sociedades, los socios suelen ocupar cargos dentro del órgano de administración, lo que implica que el control de la actuación de los administradores funcionaría, y existiría la posibilidad de la presencia del administrador de hecho con posibilidades para poder cumplir con los deberes de los administradores ${ }^{369}$.

${ }^{367}$ En esta línea explicando cómo actúan los mecanismos de control, véase SÁNCHEZ CALERO, F., Los administradores, cit., p. 44.

${ }^{368}$ En torno a la administración de la sociedad y las diferentes formas de organización para poder actuar el administrador de hecho, véase SIERRA HERRERO, A., Administradores de sociedades mercantiles y altos directivos laborales, Aranzadi, Cizur Menor, 2008, pp. 47-48.

369 Estableciendo las diferentes y vinculaciones entre los ejecutivos y los consejeros, véanse ESTEBAN VELASCO, G., "Configuración estatuaria del órgano de administración", en Derecho de sociedades anónimas: Homenaje al profesor José Girón Tena (Coord. ALONSO UREBA), Ed. Cívitas, Madrid, 1991, p. 359; QUIJANO GONZÁLEZ, J., "Responsabilidad de consejeros y directivos. La evolución de la dirección por el consejo de administración", en AA.VV., Cuaderno de derecho para ingenieros, cit., pp. 81-101. 
Por tanto, sobre la base de que el administrador de hecho actuaría en función del modelo de administración que haya adoptado la sociedad, consideramos que podría cumplir los deberes de los administradores en las SA cerradas y SRL de pequeñas dimensiones con administrador único, donde la atribución de esta función la suele ostentar un socio mayoritario.

Sin embargo, en las sociedades pequeñas o familiares donde la administración se realiza por dos administradores que actúan de forma solidaria, suele aparecer el administrador de hecho bajo la apariencia del de apoderado que tendría posibilidades para cumplir los deberes de los administradores. En cambio, si la administración es mancomunada no cabría que el administrador de hecho ejerciera los deberes de los administradores si apareciera como apoderado, precisamente, por el control entre los dos administradores formales ${ }^{370}$.

No obstante, deberemos tener presente el último factor para que el administrador de hecho pueda ejercer los deberes de los administradores, que son las facultades que puede ostentar para cumplir con todas las obligaciones que establecen los deberes a los que se encuentra obligado, ya que, si inicialmente podría pensarse que las competencias de "gestión y representación de la sociedad en los términos que vienen establecidos por la Ley" son sencillas, sin embargo, la práctica societaria nos ha demostrado que las actuaciones de los administradores son muy variadas y diversas, porque su competencia se refiere a toda una serie de actuaciones de diversa naturaleza para la consecución del fin de la sociedad ${ }^{371}$.

De ahí que, a la hora de abordar aquellas facultades que comprende la actuación del administrador de hecho, la empírica nos dibuja un amplio abanico de facultades que se caracterizan por el ejercicio principal de las actividades de gestión para la dirección de la sociedad; facultades qué tendremos que deslindar para concluir si el administrador de hecho pudo ejercitarlas para cumplir con los deberes debido a su falta de designación formal ${ }^{372}$.

\footnotetext{
${ }^{370}$ Ver por todos, DÍAZ ECHEGARAY, J. L., La responsabilidad civil de los administradores de la sociedad anónima, Ed. Montecorvo, Madrid, 1995, p. 59.

${ }^{371}$ Esta clasificación de las facultades de los administradores y los fines atribuidos a cada uno de ella, véase la establecida por ALONSO SÁNCHEZ, R., "Obligaciones básicas derivadas del deber de lealtad", cit., pp. 194-199.

${ }^{372}$ En cuanto a la clasificación de las facultades nos acogemos a la establecida por GUERRA MARTÍN, G., "La posición jurídica de los administradores de sociedades de capital", en AA.VV., La responsabilidad de los administradores de sociedades de capital, cit., pp. 39-83.
} 
En cuanto al ejercicio de la actividad de gestión o administración que se concretan en actos internos de ordenación ${ }^{373}$, constituidas por actuaciones de carácter técnico que impregnan un contenido económico financiero ${ }^{374}$, debemos advertir, como señala la doctrina, que la Ley se ha limitado a identificar las actuaciones de gestión en sentido meramente genérico y se necesita clarificar las tareas concretas que comprende. A tal efecto, se distingue entre la gestión en sentido estricto de aquellas otras actuaciones que son relativas a organizar la sociedad y, a su vez, dentro de las primeras, entre aquellas actividades que se realizarán en el ámbito interno y en el externo ${ }^{375}$.

En relación con la actividad de gestión en el ámbito interno dirigida a la planificación general para mejorar la productividad y la competitividad de la sociedad, pueden citarse, entre otros, los actos relativos a la formulación de las cuentas anuales, los informes de gestión, la propuesta de la aplicación de resultados, la distribución de dividendos a cuenta, la convocatoria de junta general, la disolución o la ejecución de acuerdos adoptados por la junta. Respecto de este tipo de actividades, siguiendo la más reciente doctrina, debemos plantearnos si pueden ser realizadas por el amplio abanico de personas que pueden calificarse como administradores de hecho ${ }^{376}$. La respuesta es que rechazamos que el administrador de hecho pueda cumplir con estas obligaciones porque son facultades exclusivas de los administradores formales. Esta opinión ya se defendió por aquella corriente doctrinal que no era partidaria de extender estas obligaciones al administrador de hecho ${ }^{377}$.

No obstante, una parte de la doctrina ha venido considerando que el administrador de hecho podría también cumplir con ciertos deberes legales, como convocar la junta cuando concurrieran las causas legales establecidas en el art. 363 LSC, y que podría solicitar el

${ }^{373}$ Véanse HERNÁNDEZ SÁINZ, E., La administración de sociedades de capital, cit., p. 32-37; LLEBOT MAJÓ, J. O., "Los Deberes y responsabilidad de los administradores", en AA.VV., La Responsabilidad de los administradores de las sociedades mercantiles (Dir. ROJO Y BELTRÁN), Ed. Tirant lo Blanch, Valencia, 2012, pp. 21-40.

374 En esta redacción hemos recogido el contenido que considera POLO SÁNCHEZ, E., Comentarios al régimen legal de sociedades mercantiles, t. VI, cit., p. 25.

375 Véase GUERRA MARTÍN, G., "La posición jurídica de los administradores de sociedades de capital", cit., pp. 42.

${ }^{376}$ En este sentido HERNANDO CEBRIÁ, L., "Presupuestos del deber de lealtad", cit., pp. 152153.

${ }^{377}$ Explicando esta corriente, véase LATORRE CHINER, N., "El concepto de administrador de hecho", cit., pp. 866-868. 
concurso de la sociedad previsto en el art. $367^{378}$. De ahí, que se susciten posturas contradictorias en torno a esta cuestión. Por un lado, aquella que sostenía que la equiparación del administrador de hecho con el de derecho no debería implicar que el primero tuviera que ejercer estas obligaciones legales ${ }^{379}$, justificando su postura en que el propio concepto de administrador de hecho se basa simplemente en un hecho y, precisamente, por ser un hecho no podrían desempeñar funciones legales al carecer de designación formal. Sin embargo, esta misma doctrina también argumentaba que se podría deducir que el administrador de hecho tendría posibilidades de cumplir con este deber porque venía ejerciendo funciones como si se tratara de un administrador formal de la sociedad y, como tal, que se le podría exigir el cumplimiento de los deberes legales por no realizarlas con en base en la culpa in omittendo.

En sentido contrario, la doctrina francesa ${ }^{380}$ predicaba que la omisión o la abstención de funciones legales no era causa para fundamentar un incumplimiento por parte del administrador de hecho. Para esa doctrina era cuestión consolidada que el administrador de hecho solo tenía una posible actuación en la realización de actos positivos y de dirección ${ }^{381}$. Por su parte, la doctrina italiana sostenía que, identificado a un administrador de hecho en la sociedad, este debería de cumplir sin excepción con cualquier deber que tuviera con el fin de velar por el correcto funcionamiento de la sociedad ${ }^{382}$.

En relación con el ámbito externo de las actividades de gestión, que se traducen en las facultades de representación atribuidas a los administradores de manera exclusiva y con carácter autónomo, su posible cumplimiento por el administrador de hecho deberá entenderse en sentido restrictivo conforme a la postura tradicional que solo reconocía al administrador de

378 Véase GARCÍA-CRUCES GONZÁLEZ, J. A., "La responsabilidad de los administradores por no promocionar remoción de la disolución de la sociedad consideraciones en torno al debate jurisprudencial", en AA.VV., La responsabilidad de los administradores, cit., pp. 48-89.

${ }^{379}$ Alertando sobre este problema de la falta de legitimación formal del administrador de hecho, véase, FUENTES NAHARRO, M., "La funcionalidad de la figura del administrador de hecho", cit., pp. 17.

380 En este sentido sobre la actuación del administrador de hecho por la doctrina francesa, DEDESSUS-LE-MOSTIEUR, N., "La responsabilité du dirigeant de fait", Rev. Soc., 1097, p. 503.

381 También, la doctrina impartida por BONELLI, G., "La responsabilità degli amministratori”, Tratato della società per azioni. Torino 1991, pp. 323-484.

382 Sobre estas consideraciones, véase FATTORI, I., "Amministrazione di fattto e azione di responsabilità individuale”, Revista La Società, Milán, 1994, p. 256. 
hecho aparente, ya que solo podría ejercer las obligaciones relativas a la gestión interna ${ }^{383}$. No obstante, se exceptuaba aquel caso en que el administrador tuviera posibilidades de actuación en el concreto caso enjuiciado, porque, si se determinaba que el administrador de hecho pudo actuar en un juicio a posteriori en el que se valoró que pudo actuar para cumplir con los deberes legales, entonces resultaría que sí le serían exigibles porque incumplió con estos deberes legales ${ }^{384}$.

La Ley vigente, con el fin de poder mantener el equilibrio del ejercicio de poder, dispuso en el art. 236.3 LSC que todos los deberes de los administradores se extendían al administrador de hecho; sin embargo, el legislador olvidó que el cumplimiento de la cláusula abstracta del deber de diligencia de un ordenado comerciante se concreta en el art. 225.1 LSC, en función de la naturaleza del cargo asignado y de las funciones atribuidas a cada administrador, modulando el nivel de exigencia del deber de diligencia. Y aquí de nuevo nos surge la cuestión de cómo cumplirá el administrador de hecho los deberes en funciones de la atribución asignada para que no se le exija responsabilidad en todas las manifestaciones de administradores de hecho, cuando por ser solo un hecho no tiene la atribución de funciones de la sociedad.

No obstante, con el estudio detallado y concreto del deber de diligencia, que será desarrollado en los epígrafes siguientes, intentaremos clarificar en qué medida los administradores de hecho van a poder cumplir con el deber de diligencia, con el fin de conformar a la corriente doctrinal que solo era partidaria de la extensión de algunos de los deberes al administrador de hecho, en función de las posibilidades que tuviera para actuar.

\subsection{La concreción del deber de diligencia con la Business Judgment Rule}

\subsubsection{El origen de la Business Judgment Rule}

La Business Judgment Rule es una regla que trae causa de un estudio elaborado por los tribunales anglosajones a principios del siglo XIX sobre el deber de diligencia con el objetivo

\footnotetext{
${ }^{383}$ Ver por todos LATORRE CHINER, N., EL concepto de administrador, cit., p. 864.

${ }^{384}$ Véase, LATORRE CHINER, N., EL concepto de administrador, cit., pp. 893-896.
} 
de poder concretarlo ${ }^{385}$. En aquel entonces existía un estándar tan general o abstracto de la diligencia que originaba gran inseguridad por su falta de concreción normativa. Esta regla tenía como propósito que los administradores pudieran reducir su miedo al riesgo al adoptar decisiones y resolver la problemática judicial en caso de incumplimiento del deber general de diligencia. La problemática surgió porque los jueces no eran expertos en temas de gestión, así como por la tendencia a sobrevalorar los acuerdos después de los resultados obtenidos. De ahí que, inicialmente, la Business Judgment Rule actuara como una presunción que siempre favorecía a los administradores cuando acreditaban que habían actuado de buena fe y con información suficiente antes de la toma de sus decisiones, para evitar que estas decisiones fueran enjuiciadas posteriormente ${ }^{386}$.

Esta regla estableció la Model Business Corporatión Act, en cuya virtud los miembros del consejo de administración cumplirían con el deber general de diligencia y con las funciones de vigilancia si una persona en la misma posición y las mismas circunstancias hubiera actuado igual, considerándose entonces que habían decidido apropiadamente ${ }^{387}$. Así que se configuró una premisa que protegía la actuación del administrador, pues solo permitía

${ }^{385}$ El primer caso que perfiló la primera formulación de lo que hoy se conoce como Bussines Judgment Rule tuvo lugar en 1829 cuando en el estado de Pensilvania consagró que, la adopción de una decisión que sobrevenga perdidas no será responsable el administrador si dicho error fue tal que cualquier hombre prudente hubiera incurrido (STS de Pensilvania de 1829 Percy. Millaudon); en igual sentido STS de Alabama Godbold vr. Branch Bank de 1847; STS Rhode Island Hodges $v r$. New England Screw Co, de 1850. Esta regla surgió en el estado de Delawere para proteger a los administradores contra las decisiones del deber de diligencia y, además, solo se les podía declarar responsables por negligencia grave, es decir era necesario, fraude, ilegalidad o una actuación interesada, STS Delaware Aronson v. Lewis 1984, véase BARTON, N. \& RADIN, S., The Business Judgment Rule: fiduciary Duties of Corporate Directors, Nueva York, 1998, pp. 12-18.

${ }^{386}$ La Business Judgment Rule y su incorporación en el sistema societario español GUERRA MARTÍNEZ, A., "La cuestionada deseabilidad económica de la business judgment rule en Derecho español”, Working Paper Series, Facultad de derecho de la universidad CEU San Pablo, 2014, pp. 5-8.

${ }^{387}$ Act.8.33b) de la Model Business Corporation de la American Bar Fundation. Sección 4.01(c) de los Principles of Corporate Governance de American Law Institute: Los consejeros o ejecutivos que adopten de buena fe una decisión empresarial cumplen el deber establecido en la presente Sección si: 1) no están interesados en el asunto objeto de la decisión empresarial; 2) están informados respecto de la materia objeto de la decisión empresarial en la medida en que el correspondiente consejero o ejecutivo considere razonablemente que la decisión es adecuada dadas las circunstancias; (3) creen racionalmente que dicha decisión empresarial sirve mejor al interés de la sociedad. Sección. 4.02 8c) (2) se considerará que han recabado "información suficiente" cuando en palabras del ALI "están informados respecto a la materia objeto de la decisión empresarial en la medida en que el correspondiente consejero o ejecutivo considera razonablemente adecuada dadas las circunstancias. 
la revisión judicial de su decisión si se acreditaba que los administradores adoptaron el acuerdo con mala fe o infringido el deber de lealtad ${ }^{388 .}$

No obstante, para su aplicación coexistían dos posiciones antagónicas. La primera, la mayoritaria sostenida por los Tribunales de Delawere que consideraban que esta regla no era un estándar de conducta que sirviera para fundamentar el cumplimiento del deber general de diligencia (duty of care) o el de lealtad (duty of loyalty), sino un estándar de revisión de la conducta de los administradores que serviría como criterio para valorar si habían infringido el deber de diligencia. La segunda, surgida a principios de los años 80, proviene del American Law Institute que elaboró un proyecto que comprendía los principios de gobierno corporativo, el Proyecto ALI, que recogía que esta regla se debía de entender como un estándar de conducta que sirviera para concretar el contenido del deber de diligencia de los administradores. Así, si los administradores cumplían con sus presupuestos, sus decisiones no se revisarían porque habían cumplido el deber general de diligencia.

Sin embargo, la aplicación de esta regla sufrió un importante cambio de criterio. Aunque en un principio se implantó como criterio de abstención solo juzgando las decisiones negligentes y graves, se empezaron a revisar las decisiones por los desfalcos financieros originados en los EEUU que incrementaron las demandas ${ }^{389}$. Por otro lado, este cambio se produjo porque esta regla había consagrado la exculpación de los administradores y la situación varió cuando, en determinados casos, no se podía aplicar esta regla porque había una

388 Véase, GUERRERO TREVIJANO., El deber de diligencia de los administradores en el gobierno de las sociedades de capital, cit., pp. 61-65. Principles of Corporate Governance, Sección 4.01a) que establece el concepto de deber de diligencia los consejeros y directivos están obligados ante la sociedad a desempeñar de buena fe las funciones de consejero ejecutivo, del modo que crean razonablemente que mejor sirve a los intereses de la sociedad y con el cuidado.

389 Caso W. Disney Co, véase GROSS-BROWN, S., "Deberes de administradores en el derecho comparado. El deber de diligencia y el Business Judgment Rule", RdS, núm. 37, 2011, p. 312. "Demandaron al Consejo de administración por la contratación y posterior despido de su director general, a quién se le indemnizo con 170 millones de dólares. El núcleo del problema gira en torno a la responsabilidad por culpa ante una pura decisión de negocios: La contratación el 1 de octubre de 1995 y posterior despido, el 12 de diciembre de 1996, de un empleado a quién ya se había contratado con los emolumentos más altos de la industria de aquel entonces (27 millones de dólares más bonos y stock options). Los accionistas alegaron que el Consejo de Administración había incumplido su deber de diligencia al contratar y, posteriormente, destituir, a los nombraron como presidente y que tal actuación fue gravemente negligente o realizada de mala fe causando un grave perjuicio al patrimonio social. 
desviación de su poder y se consideraba que los acuerdos habían sido lesivos para los intereses de la sociedad ${ }^{390}$.

Debemos recordar, entre otros, el caso $\mathrm{ENRON}^{391}$ y sus efectos desencadenantes; en particular, los escándalos financieros derivados de las graves infracciones del deber de diligencia que trajeron la promulgación de una Ley Federal en Estados Unidos con normas muy estrictas en las sociedades cotizadas ${ }^{392}$; a partir de ahí, se examinaron las actuaciones de los administradores dejando a un lado el hecho de que no se revisarían los actos de los administradores, salvo que se demostrara culpa grave o gross negligence $\mathrm{y}$, de esta forma, esta regla ya no podría operar como eximente. El resultado fue que los tribunales americanos revisaron las decisiones valorando si los administradores se habían informado para el desarrollo y elaboración de las decisiones y, sobre todo, si los administradores habían actuado con negligencia grave ${ }^{393}$.

Al mismo tiempo, en el derecho comparado surgía otra problemática, la derivada de su falta de denominación. Aunque, como esta regla consistía más bien en un conjunto de principios que deben cumplir los administradores, se incorporó en los ordenamientos jurídicos mediante diferentes niveles de asimilación y de aplicación. Algunos la adoptaron como regla de derecho positivo, como Alemania; sin embargo, en Italia se adoptó como principio judicial $^{394}$.

${ }^{390}$ En este sentido, véase la STS de 1 de noviembre de 2002 (RJ 1086/2002) que acogía esta regla para pronunciarse sobre la diligencia o no de los administradores".

${ }^{391}$ ENRON, empresa que se dedicaba a la distribución de gas natural en Texas a mediados de 1985, "se convirtió en la comercializadora más grande en los EEUU, después incursionó en negocios, como Internet, energía, entre otros, y ha sido unos de los fraudes más conocidos a nivel mundial, ya que sucedió en una de las empresas más prometedoras en Estados Unidos. Sin embargo, de lo que se hablo fue de cómo estaban cubriendo cada una de las deudas que tenían, pues aunque generaban grandes ganancias, no registraban las deudas, que superaban a las ganancias y cuando se descubrió el fraude salió a flote la verdad de su auditor, ya que estos habían distribuido toneladas de documentos con información que demostraba las actividades que llevaron a la quiebra a ENRON, se dice que si la empresa auditora hubiera realizado su trabajo presentado informes con la información verdadera, ENRON estaría todavía en el mercado".

${ }^{392}$ Sarbanes-Oxley Act, de 2002 (SOX) presento un marco de responsabilidad muy agravado.

${ }^{393}$ Caso Smith vs. Van Gorkon 488 A.2d 858 (Delawere 1985) estableció los criterios para revisar las decisiones de los administradores.

${ }^{394}$ Sobre el derecho comparado, explicando esta regla en el derecho estadunidense, Alemania, Italia, Rumania, Grecia, Croacia, Portugal, véanse GARRETA SUCH, J.M., La diligencia, cit., pp. 58-65 y GUERRERO TREVIJANO, C., El deber de diligencia de los administradores, cit., pp. 39-81. 
El Derecho alemán recogió esta regla en la Ley $A k t G$, en el año $2005^{395}$, bajo la rúbrica del deber de diligencia y responsabilidad de los miembros en la dirección, presumiendo que la actuación de los administradores era diligente cuando se había actuado conforme a los principios que la consagraba ${ }^{396}$. Así, la diligencia de los administradores no se entendería sin analizar, previamente, los principios que encierra esta regla. Y, de esta manera se creó un puerto seguro, safe harbor, que protegía a los administradores si demostraban que sus decisiones se encontraban cubiertas con los elementos que encerraba esta regla, de tal modo que los jueces no entraban a valorar sus decisiones. Con esta política se pretendía evitar el riesgo de juzgar, a posteriori, al administrador sobre unos hechos que se conocieron después de aquel momento en qué se había tomado la decisión. También, hay que tener en cuenta que la administración de las sociedades en Alemania se corresponde con el sistema dualista, donde la administración se encuentra dividida en dos órganos, el primero, el órgano de dirección encargado de la gestión y, el segundo, el consejo de vigilancia cuya función principal es la de supervisar la gestión del órgano de dirección ${ }^{397}$, lo que implica que la diligencia no se encontrara definida en el consejo de vigilancia.

Por su parte, en el ordenamiento italiano el concepto de una actuación diligente no estaba definida $\mathrm{y}$, por ello, los tribunales cuando revisaban la diligencia de los administradores utilizaban unos criterios que les servían para configurar el estándar de conducta, que son muy semejantes a los principios de la regla Business Judgment Rule. Estos principios, Insindicabilitá delle scelte gestionali o incuestionabilidad, se traducen en que la revisión judicial se limitará a controlar el procedimiento que se siguió en la decisión del administrador, sin revisar su contenido ${ }^{398}$.

\footnotetext{
${ }^{395}$ Ley de sociedades anónima alemana, la Aktiengestz (AktG), en el art. 93.1. $1^{\text {o }}$, establece que "los miembros de la dirección han de proceder con la diligencia de un gerente ordenado y cuidadoso en el desarrollo de sus funciones gestoras".

${ }^{396}$ Véase Gesetz zur Unternehmensintegrität und Modernisierung des Anfech-tungsrechtes (UMG) de 22 de septiembre de 2005, que modifico el\&93 AktG.

${ }^{397}$ Para un mayor estudio, sobre el sistema dualista del órgano de administración, y en particular, en el derecho alemán, véanse ALONSO UREBA, A., "Mejoras en la estructura", cit., pp. 18-24; LUTTER, M., "Die Business Judgment Rule und ihre pratische anwendung", en ZIP, núm. 18, 2007, p. 846.

398 Véase GUERRERO TREVIJANO, C., El deber de diligencia de los administradores, cit., pp. 76-81.
} 
Por otro lado, la Companies Act del Reino Unido no contiene referencia expresa a la regla Business Judgment Rule, solo menciona que los administradores deberán evitar los conflictos de intereses.

\subsubsection{Objetivo y requisitos de la protección de la discrecionalidad} empresarial o Business Judgment Rule

La Ley 31/2014 concretó el deber de diligencia cuando se incorporó la protección de la discrecionalidad empresarial en la LSC. Su objetivo es que operara como garantía para los administradores si sus decisiones resultaban erróneas o no beneficiosas para la sociedad. En concreto, el art. 226.1 LSC establece que, "En el ámbito de las decisiones estratégicas y de negocio, sujetas a la discrecionalidad empresarial, el estándar de diligencia de un ordenado empresario se entenderá cumplido cuando el administrador haya actuado de buena fe, sin interés personal en el asunto objeto de decisión, con información suficiente y con arreglo a un procedimiento de decisión adecuada”.

Ciertamente, esta regla ${ }^{399}$ ya venía siendo aplicada por los tribunales para revisar las decisiones económicas de los administradores que escapaban de sus conocimientos con el fin de determinar si habían sido adoptadas conforme al estándar de un ordenado empresario.

Sin embargo, para entender el objetivo de esta, primero conviene acudir a la doctrina americana que se asienta sobre cinco pilares fundamentales. El primero, alentar a los administradores para que adopten decisiones, aunque el resultado fuera negativo cuando su decisión reúne los requisitos que establece esta regla, es decir, que la decisión se haya adoptado de forma desinteresada con buena fe; esta es una presunción, aunque de iuris tamtum implicara tener que analizar si el administrador ha actuado de buena fe. El segundo, promover que los administradores no tengan miedo en asumir riesgos a la hora de adoptar sus decisiones si han sido adoptadas con el requisito de información previa y con un procedimiento adecuado. Estos dos conceptos, por ser conceptos jurídicos indeterminados, no

\footnotetext{
${ }^{399}$ En este sentido SSTS de 29 de marzo de 2007 (RJ 377/2007); de 6 de octubre de 2010 (RJ 569/2010). Explicando esta regla por la doctrina más reciente EMBID IRUJO, J. M., "La protección de la discrecionalidad empresarial: artículo 226", cit., pp. 105-133; GUERRERO TREVIJANO, C., El deber de diligencia, cit., pp. 48 y ss.; RONCERO SÁNCHEZ, A., "Protección de la discrecionalidad empresarial y cumplimiento del deber de diligencia", en AA.VV., Junta general, cit., pp. 386-423.
} 
permite presumirlos, y su cumplimiento deberá acreditarse junto con el principio de decidir sin interés personal. El tercero, evitar que sus decisiones sean revisadas a posteriori por los jueces. El cuarto, limitar acciones judiciales contra los administradores por los resultados obtenidos. Y, el quinto, que no se utilicen las acciones como censura por el resultado negativo para sustituir del cargo a los administradores, ya que su objetivo es infundir seguridad a los administradores con fuertes presionas en la adopción de sus decisiones, aunque en algunas ocasiones resulten perjudiciales para la sociedad ${ }^{400}$. En síntesis, presupone ${ }^{401}$ que la actuación de un administrador fue diligente si se adoptó siguiendo sus presupuestos. Así que una vez acreditados sus requisitos se entendería que se cumplió con el estándar de un ordenado empresario $^{402}$.

Por consiguiente, el objetivo fundamental de esta regla encuentra su base en la razonabilidad, que servirá para poder determinar la discrecionalidad gestora y al tiempo concretar el deber general de diligencia ${ }^{403}$.

No obstante, habría que plantearse la cuestión de si este blindaje que se ha establecido a los administradores sería el método más adecuado para un mercado como el español donde, a diferencia del contexto de las sociedades norteamericanas, apenas hay diversificación del capital en la mayoría de las SA no cotizadas, y en particular, en pequeñas y medianas empresas o empresas familiares ${ }^{404}$.

\footnotetext{
${ }^{400}$ Véase GUERRERO TREVIJANO, C., El deber de diligencia, cit., p. 246.
}

401 Véase el estudio detallado de los requisitos de la Business Judgment Rule que establece HERNANDO CEBRIÁ, L. El deber de diligente administración en el marco de los deberes de los administradores sociales. La regla del buen juicio empresarial, cit., p. 120.

402 Sobre el cumplimiento de los requisitos de la discrecionalidad empresarial, véase EMBID IRUJO, J. M., "La protección de la discrecionalidad empresarial”, cit., pp. 108-115.

${ }^{403}$ En este sentido, para la concreción del deber de diligencia se necesitará un procedimiento que sea razonable, GUERRA MARTÍN, G., El gobierno de las sociedades cotizadas estadounidenses, cit., p. 437; SÁNCHEZ CALERO, F., Los administradores, cit., p. 167.

${ }^{404}$ Estableciendo esta cuestión para ser valorada la aplicación de esta regla en nuestro sistema societario, véase GARCÍA MALDONIZ, M., "Inconcreción del deber diligente", cit., pp. 404-410. 


\subsection{3. Ámbito de aplicación}

El ámbito de aplicación de esta regla, como medida de concreción del deber de diligencia, se circunscribe a las decisiones de carácter estratégicas y de negocio. Debe platearse entonces, ¿qué se entiende por este tipo de decisiones? La respuesta no es sencilla por ser un concepto indeterminado y de no fácil interpretación. Generalmente se considera que son decisiones que se refieren a acuerdos relacionados con actividades comerciales e inversiones $^{405}$.

Consecuentemente, deslindar la aplicación de la regla de la Business Judgment Rule en este tipo de decisiones no es tarea fácil, como acreditan la existencia de diversas posturas interpretativas ${ }^{406}$. Así que distinguiremos entre el estándar de conducta (standard of conduct) que establece cómo deberá actuar el administrador para desempeñar estas decisiones, y el estándar de revisión (standard of revisión) cuando el administrador incumplió con su deber general de diligencia, es decir, la Business Rule Judgment ${ }^{407}$.

El ámbito de protección de la discrecionalidad empresarial por el que optó el art. 226 LSC se refiere a su consideración como estándar de conducta, aplicando esta regla como un safe harbor o puerto seguro. Es decir, solo se necesitaría la intervención del juez para

${ }^{405}$ Véase RECALDE CASTELLES, A., "La prueba de la regla de la discrecionalidad empresarial (<<business judgment rules $>>)$ ), en AA.VV., Estudios sobre órganos de las sociedades de capital, cit., pp. 1051-1071.

${ }^{406}$ La delimitación de la discrecionalidad empresaria y el cumplimiento del deber de diligencia, véanse EMBID IRUJO, J. M., "La protección de la discrecionalidad empresarial", cit., pp. 108-109 y pp. 113-115; MATEU DE ROS CEREZO, R., Practica de Gobierno Corporativo, cit., pp. 58-59; PAZ-ARES RODRÍGUEZ, C., "La responsabilidad de los administradores como instrumento de gobierno corporativo", cit., pp. 67-109; RAMOS CAVO, M. D., "Derecho de la competencia y deberes de diligencia", $R d S$, núm. 42, 2014, p. 162; SAÍNZ MORENO, F., Conceptos jurídicos, interpretación y discrecionalidad empresarial, Ed. Cívitas, Madrid, 1979; VALPUESTA GASTAMINZA, E., Comentario a la Ley de Sociedades de Capital, cit., pp. 620-622.

${ }^{407}$ Un ejemplo de esta regla como doctrina de abstención la encontramos en el caso Shensky vs. Wrigley Delawere, 1968 en la que el demandado Wrigley alegó en su defensa que los tribunales no interferirían en el honesto juicio de los administradores a menos que se evidencie la existencia de fraude, ilegalidad o conflicto de intereses entre los administradores y los intereses de la sociedad, véase HERNANDO CEBRIÁ, L., El deber de diligente administración en el marco de los deberes de los administradores sociales, cit., p. 120-245. 
comprobar cómo se adoptó esa decisión empresarial, y los administradores solo deberían demostrar que sus decisiones se adoptaron cumpliendo los requisitos de esta regla ${ }^{408}$.

No obstante, se plantean diversas interrogantes como, ¿la regla del juicio empresarial clarificará la diligencia que es exigible para adoptar este tipo de decisiones?, y, en cualquier caso, ¿este nuevo artículo permite que los administradores adopten decisiones de buena fe cuando de manera informada van encaminadas a poder conseguir el mejor interés de la sociedad en una situación de crisis económica? ${ }^{409}$. Para hallar una respuesta a estas interrogantes deberemos diferenciar entre que la sociedad se encuentre o no en situación de desequilibrio económico ${ }^{410}$.

Cuando la sociedad no se encuentra en desequilibrio económico la protección de la discrecionalidad empresarial se aplicaría porque los administradores pueden optar por diversas alternativas para tomar sus decisiones. En cambio, en situación de crisis económica difícilmente se aplicaría esta regla cuando concurren los requisitos necesarios para disolver la sociedad o solicitar el concurso de la sociedad, ya que en estos casos el administrador deberá de cumplir con sus obligaciones legales, pues su omisión implicaría su responsabilidad. Estas obligaciones legales serán objeto de estudio cuando abordemos la responsabilidad de los administradores en el capítulo tercero.

Ahora bien, debemos puntualizar que cuando las decisiones estratégicas hubieran sido adoptadas con mala fe o buscando el propio interés de los administradores, según lo que establece el art. 226.2 LSC, los administradores quedarán excluidos de la protección de esta regla por contravenir el deber de lealtad conforme a los presupuestos que se indican el precitado artículo ${ }^{411}$. En concreto, se prevé que, "No se entenderán incluidas dentro del

\footnotetext{
${ }^{408}$ Se trata de una presunción a favor de los administradores, que no opera directamente pues serán los administradores los que deberán acreditar que su actuación ha sido diligente, véanse, GUERRERO TREVIJANO, M., El deber de diligencia, cit., pp. 243.

${ }^{409}$ Esta cuestión es una de las interrogantes que los administradores deben decidir con la posibilidad de incurrir en el incumplimiento del deber de diligencia ante una crisis económica en la sociedad, véase GUERRERO TREVIJANO, M., El deber de diligencia, cit., pp. 442 y ss.

${ }^{410}$ En torno a la solución de estas cuestiones SÁNCHEZ CALERO, F., Los administradores. cit., p. 167.

${ }^{411}$ El deber de lealtad aparece en la aplicación de esta regla como excepción cuando los administradores tienen interés personal en la toma de estas decisiones ALFARO ÁGUILA-REAL, J.,
} 
ámbito de la discrecionalidad aquellas decisiones que afecten personalmente a otros administradores y por personas vinculadas". Así, no se aplicará en aquellas decisiones que afecten a relaciones personales del administrador ni que afecten a personas vinculadas con el administrador. Por ejemplo, si el administrador utiliza activos sociales o se aprovecha de una concreta oportunidad de negocio, si el administrador obtiene una ventaja, o si recibe remuneración de un tercero con la decisión que adoptón ${ }^{412}$.

En definitiva, esta medida favoreció el ejercicio del cargo de administrador al aminorar en cierto modo el riesgo implícito de sus decisiones, a la vez que supuso un avance importante para la concreción del deber de diligencia, pues establece unas pautas que permiten entender cuando el administrador cumplirá o no con tal deber que, como es bien sabido, conlleva un elevado componente de discrecionalidad e incertidumbre ${ }^{413}$.

Al trasladar la aplicación de esta regla al administrador de hecho para cumplir el deber de diligencia, entendemos que se verá limitado con respecto al administrador por la falta de disposición de medios y por la obtención de la información previa, dada su falta de designación formal ${ }^{414}$.

No obstante, hay que advertir que el deber de diligencia sigue subsistiendo como obligación bajo los presupuestos establecidos en el art. 236 LSC, respecto al resto de decisiones que comprenden la actuación de los administradores, al no encontrarse en el

"La protección de la discrecionalidad empresarial", en AA.VV., Comentarios de la reforma, cit., pp. 325-351.

${ }^{412}$ En relación, a aquellas decisiones excluidas dentro del ámbito de la discrecionalidad empresarial, véase EMBID IRUJO, J. M., "La discrecionalidad empresarial”, cit., pp. 121-123.

${ }^{413}$ El riego es inherente en las decisiones por esta razón se aplicará la regla si reúne sus requisitos para poder avanzar en el cumplimiento de deber de diligencia ALFARO ÁGUILA- REAL, J., "Articulo 225. Deber general de diligencia", cit., pp. .330-360.

414 De nuevo aparece la limitación para ejercer los deberes de los administradores por el administrador de hecho tal y como nuestra doctrina resolvía antes de que se promulgara la Ley 31/2014 véanse, DÍAZ ECHEGARAY, J., Deberes y responsabilidad de los administradores, cit., p. 231; EMBID IRUJO, J. M., Recensión al libro El deber de diligente administración en el marco de los deberes de los administradores sociales. La regla del buen juicio empresarial de Luis Hernando Cebriá, Madrid, 2009, pp. 13-17; GARCÍA MALDONIZ, M., "Inconcreción del deber de diligente administración”, cit., p. 405; LLEBOT MAJÓ, J. O., Los deberes de los administradores, cit., p. 142. 
ámbito de aplicación objetivo de la protección de la discrecionalidad empresarial que abordaremos en el capítulo tercero ${ }^{415}$.

\subsection{Los deberes específicos del deber de diligencia}

La Ley 31/2014 determinó, en el art. 225. 2 LSC, los deberes específicos del deber de diligencia con las obligaciones de dedicación adecuada y de adoptar las medidas precisas para la buena dirección y el control de la sociedad". Este deber paradigmático se concreta en el art. 225.3 LSC con el deber específico de que, "Los administradores tienen el deber de exigir información a la sociedad y el derecho de recabar la información”. A pesar de estas referencias, siguen existiendo problemas para su concreta delimitación debido al carácter discrecional que impregna el actuar con la debida diligencia.

El catálogo legal de las concretas manifestaciones del deber general de diligencia quedó reflejado como deberes específicos, pero, debido a su difícil sistematización nos acogemos al criterio de nuestra doctrina, clasificando a estos deberes específicos en los siguientes: deber de dedicación adecuada, de control y vigilancia, compliance, de participación, de información, de profesionalidad y de independencia. Al tiempo, deben completarse los deberes específicos con los deberes legales, estatutarios, tributarios, de defensa de la competencia, administrativos y penales que les sean de aplicación ${ }^{416}$.

Sin embargo, la LSC establece una cierta objetivación del deber de diligencia en el art. 225.1 LSC con base en la cláusula general de un ordenado comerciante, junto con las funciones atribuidas, la naturaleza del cargo y la dedicación adecuada, tecnificando su ejercicio con un comportamiento profesional prudente y con preparación ${ }^{417}$. Actuar diligentemente requiere una prudencia de cuidados especiales y atenciones superiores a los de un hombre medio, así que para desempeñar el cargo de administrador se requiere

${ }^{415}$ Precisando que la aplicación de esta regla no dispensa a los administradores de actuar conforme al estándar de diligencia, véase GARRETA SUCH, J. M., La diligencia, cit., p. 120.

${ }^{416}$ Ver por todos, la clasificación de estos deberes específicos de nuestra doctrina LLEBOT MAJÓ, J. O., "Los deberes y la responsabilidad de los administradores", cit., pp. 29-34.

417 Sobre el carácter objetivo de la diligencia, véase HERNADO CEBRIÁ, L., "El deber de diligencia: artículo 225", cit., pp. 66-69. 
profesionalidad para la gestión de los intereses ajenos ${ }^{418}$. De ahí que la profesionalidad que se exige es la actuación de personas dedicadas a actividades empresariales con conocimientos técnicos de forma habitual y de las reglas de pericia ${ }^{419}$. En este sentido se pronunció nuestra jurisprudencia en SAP de Pontevedra de 2009 (RJ 2198/2009), haciendo referencia a conceptos de capacitación técnica, especialización y pericia ${ }^{420}$.

Sin embargo, la Ley 31/2014 no incluyó el término pericia en su articulado, simplemente se limitó a introducir la expresión "naturaleza del cargo"421. Ahora bien, si atendemos a lo establecido en el art. 225.2 LSC cuando dice que, "Los administradores deberán tener la dedicación adecuada y adoptarán las medidas precisas para la buena dirección y el control de la sociedad", observaremos que aparece la expresión "dedicación adecuada" y entonces sí que de ella podría inferirse que el deber de diligencia se concretaría en función de la especialización que ostenta el administrador, del tipo de sociedad y de las funciones atribuidas ${ }^{422}$.

Por otro lado, el deber de diligencia se concreta con el deber específico del deber de control y la función de compliance, que es la obligación de dirección y de vigilancia en la sociedad para cumplir la legalidad interna y externa; y aquí nos encontramos con el deber especifico de tener que adoptar las medidas precisas para la buena dirección y control de la

${ }^{418}$ Véase SÁNCHEZ CALERO, F., Los administradores en las sociedades de capital, cit, p. 183.

419 "El deber de diligencia de ordenado empresario exige que los administradores inviertan una determinada cantidad de tiempo y esfuerzo y desplieguen un cierto nivel de pericia en la gestión o supervisión de la empresa a fin de matizar la producción de valor", véase PAZ-ARES RODRÍGUEZ, C., "La responsabilidad de los administradores como instrumento de gobierno corporativo", cit., p .69.

${ }^{420}$ La diligencia exigida a los administradores en el ámbito de las sociedades capitalistas es una diligencia profesionalizada que la doctrina califica como diligencia de medios y no de resultados". En este sentido, SAP de Pontevedra de 2009 (RJ 2198/2009).

${ }^{421}$ Conforme a aquella corriente doctrinal que predicaba que la pericia no sería necesaria en el concepto de la diligencia ya que al administrador no se le debería de exigir que fuera un experto en todos los ámbitos de gestión de la sociedad. No debemos olvidar que ni para el empresario ni para ser administrador se requiere legalmente ningún tipo de capacitación que le habilite para el ejercicio profesional y que no siempre los dirigentes de más éxito son los que mejor formación empresarial han recibido, véase POLO SÁNCHEZ, E., "Los administradores y el consejo de administración", cit., p. 134.

${ }^{422}$ Explicando la adecuación de la diligencia exigible al administrador en proporción al concreto ámbito de la sociedad donde se actúe el administrador y, su importancia, véase HERNADO CEBRIÁ, L., "El deber general de diligencia: artículo 225", cit., p. 63. 
sociedad previsto en el art. 225.2 LSC $^{423}$. Es decir, adoptar medidas precisas mediante un sistema de gestión de riesgos para la prevención de impactos negativos ante situaciones imprevistas a fin de que la actuación se considere diligente, y que se complementa con el deber especifico de investigación, que implicará participar en las tareas de administración con iniciativas y supervisión de la sociedad ${ }^{424}$.

Lo anteriormente expuesto corrobora nuevamente la imprecisión de la definición del concepto de administrador de hecho establecida en el art. 236.3 LSC, ya que de nuevo tendremos que acudir a las consideraciones doctrinales por su modo de actuar en la sociedad. En concreto, si dirige habitualmente las tareas de los administradores con profesionalidad y con el consentimiento de la sociedad, entonces dilucidaremos como debería actuaría esta figura dependiendo del tipo de sociedad, con el fin de cumplir con todos los deberes a los que se encuentran sujetos los administradores ${ }^{425}$.

Hay que resaltar que el ejerció del deber especifico de vigilancia o compliance viene regulado, como competencia para el administrador de hecho y los de derecho, para las SRL en el ámbito penal al objeto de conseguir la exención de la responsabilidad.

Respecto al concreto ejercicio del deber especifico de información por el administrador de hecho consideramos que, de nuevo, se nos plantea otra cuestión, ¿cómo el administrador de hecho podrá ejercer el deber de diligencia por su modo de actuar cuando adopte decisiones si no se encuentra legitimado para ello? La razón de esta cuestión encuentra su base en que, si los administradores tienen la obligación de exigir la información que sea adecuada para cumplir sus funciones, entonces el administrador de hecho no podrá cumplirla porque esta

${ }^{423}$ Véase DEL VAL TALENS, P., El administrador persona jurídica en las sociedades de capital, cit., pp. 328-331.

${ }^{424}$ Véanse DÍAZ RUÍZ, E., "La coordinación de los administradores solidarios de las sociedades de capital como manifestación del deber de diligencia", en AA.VV., Estudios sobre los órganos de las sociedades de capital, cit., pp. 1003-1021; sobre la dedicación adecuada HERNANDO CEBRIÁ, L., "El deber de diligencia: artículo 225", cit., pp. 79-83: Los deberes de los administradores parte central del gobierno corporativo MATEU DE ROS CEREZO, R., Práctica de Gobierno Corporativo, cit., pp. 55-56. MAMBRILLA RIVERA, V. M., "Las concretas manifestaciones del deber general de diligencia de los administradores", en AA.VV., Junta general y Consejo de administración, cit., pp. 345-381. Concretando el deber de diligencia en relación a la organización de la sociedad RODRÍGUEZ ARTIGAS, F., "El deber de diligencia", cit., p. 430.

${ }^{425}$ Estableciendo esta consideración EMBID IRUJO, J. M., “Todos son (y serán) administradores”, cit., pp. 1-2. 
obligación no puede ser ejercida por un tercero; de ahí que el administrador de hecho no podrá conocer lo que sucede en la marcha de la sociedad ni decidir con conducta diligente a pesar de que venga ejerciendo funciones de administrador ${ }^{426}$.

Por nuestra parte rechazamos que el administrador de hecho pueda cumplir en el deber de diligencia, salvo para el caso en particular del administrador de hecho en su manifestación oculta $^{427}$. En este caso son los administradores formales los que disponen de los medios necesarios para cumplir con las pautas de los concretos deberes específicos del deber de diligencia bajo las instrucciones impartidas por el administrador oculto. En cambio, el administrador de hecho notorio, o el que actúa bajo la apariencia de otro título, aunque realicen las funciones de los administradores, no se encuentran legitimados por la sociedad.

\subsubsection{El deber y derecho de información}

El deber de información, duty inquire, fue incorporado por la Ley de Transparencia en el art. 127.1 LSA. En concreto, señala que los administradores "deberán informarse diligentemente de la marcha de la sociedad" "228. Posteriormente, se contempla en el art. 225.2 LSC, antes de que se operase la reforma de la Ley 31/2014.

Sin embargo, en el proyectado art. 283 del Anteproyecto de Código Mercantil (en adelante, APCM) no se refleja este deber de exigir la información adecuada y necesaria para que los administradores puedan cumplir con sus obligaciones, pues solo mantiene la obligación. Así, los administradores deben informarse sobre la marcha de la sociedad. En cambio, en el art. 225.3 LSC se establece expresamente el deber de exigir información y el

\footnotetext{
${ }^{426}$ Sobre la información contable DEL CASTILLO IONOV, R., "La información societaria (II): La contabilidad, el deber de información complementaria en la memoria y los instrumentos especiales de información (artículos 536 y 539 en la Ley de sociedades de capital)", cit., pp. 956-977 y pp. 956-959 y sobre el deber de diligencia y las dificultades de su cumplimiento por el administrador de hecho, véase la obra detallada de GUERRERO TREVIJANO, C., El deber de diligencia, cit., pp. 167-168.

${ }^{427}$ Estableciendo la extensión subjetiva del deber de diligencia al administrador de hecho oculto, véase. HERNANDO CEBRIÁ, L., "Presupuestos del deber de lealtad: artículo 227.1”, cit., pp. 152153.

${ }^{428}$ Véase GUERRA MARTÍN, G., "La aplicación analógica a las cajas de ahorro del derecho de sociedades anónimas en relación al derecho de información de los consejeros", $R d S$, núm. 24, Madrid, 2005-1, pp. 277-295.
} 
derecho a poder acceder a los datos que serían necesarios para ejercitar sus funciones ${ }^{429}$, según el cual, "el administrador tiene el deber de exigir y también, el derecho de recabar de la sociedad información adecuada y necesaria para el cumplimiento de sus obligaciones". De ahí que el deber de información se convirtió en facultad reversible para los administradores, ya que comprende tanto un deber como un derecho.

Por consiguiente, la Ley 31/2014 mantuvo la relevancia del deber de información de los administradores para cumplir sus funciones y dispuso que los administradores, antes de tomar sus decisiones, deberían de exigir la información necesaria. El deber de información se contempla como eje central de la diligencia que es exigible al administrador en el ejercicio de sus funciones.

No obstante, debemos resaltar que, si el ejercicio del deber de información es una facultad que debe ejercitarse individualmente conforme a las funciones atribuidas, por el contrario, el derecho a recibir información no sería una facultad individual, sino que más bien comprendería un ejercicio colectivo, pues la información se debería suministrar al conjunto de los integrantes del órgano de administración ${ }^{430}$. Hay que recordar que el derecho de información, pese a su gran importancia, no había sido expresamente regulado en nuestra legislación societaria y, por este motivo, se abordó por la jurisprudencia y doctrina ${ }^{431}$. El

${ }^{429}$ El deber de información es elemento esencial del deber de diligencia que se configuró como derecho y deber de los administradores con el fin de poder cumplir el deber general de diligencia, véase VELASCO SAN PEDRO, L. A., "La información en el consejo de administración; derechos y deberes del Consejo de los consejeros", en AA.VV., El gobierno de las sociedades cotizadas, cit., pp. 305-369, pp. 324-347.

${ }^{430}$ La doctrina más especialista, en esta materia, ya venía estableciendo esta consideración afirmando que, "Todo administrador de cualquier sociedad, para desempeñar como es debido sus funciones, tiene que estar informado de lo que ocurre en la empresa. La información es un componente sustancia del deber de diligencia, pues no puede considerarse diligente quien pretende gestionar una sociedad ignorando, en mayor o menor medida, lo que sucede en ella". En concreto, afirma que "Todo administrador de cualquier sociedad, para desempeñar como es debido sus funciones, tiene que estar informado de lo que ocurre en la empresa. La información es un componente sustancia del deber de diligencia, pues no puede considerarse diligente quien pretende gestionar una sociedad ignorando, en mayor o menor medida, lo que sucede en la sociedad", véase MUÑOZ PAREDES, J. M., La información de los consejeros en la sociedad anónima, Ed. Aranzadi, Pamplona, 1999, pp. 28 y ss. MUÑOZ PAREDES, J. M., "El derecho de información de los administradores tras la Ley de Transparencia", Diario La Ley, núm. 6078, 2004.

431 En este sentido, SSAP de Cantabria de 14 de mayo de 2009 (RJ 364/2009) donde al administrador no se facilitó toda la documentación; y SAP de Madrid de 6 de marzo de 2015 (RJ 300/20015) en la que se negó a los administradores información relevante sobre el acuerdo adoptado vulnerando su derecho de información. 
derecho de información delimita en gran medida el contenido del deber de diligencia; en este sentido, es de destacar las SSAP de Cantabria de 14 de mayo de 2009 (RJ 364 /2009) y de Madrid de 6 de marzo de 2015 (RJ 300/20015) (32 $^{4}$, que se fundamentan en el propio cargo de administrador, por ser facultad imprescindible para desempeñar las funciones específicas que legalmente tienen atribuidas ${ }^{433}$.

Si nos acercamos a la letra de la Ley, el deber de información se ha configurado como un presupuesto necesario para realizar el de diligencia, pues es una conducta que deberá exigirse a los administradores para que se informen y puedan obtener una opinión de la realidad del negocio ${ }^{434}$. Así que la actuación diligente solo se podrá demostrar si el administrador previamente se informó del funcionamiento de la sociedad para adoptar una decisión ${ }^{435}$. En este sentido, se trata de la información que nos proporciona la contabilidad ${ }^{436}$ de cada sociedad, según dispone el art. 25 del CCom, pues, actualmente, la información contable es el instrumento más acorde para tener conocimiento del pasado, presente y futuro de la realidad económica de la empresa con base en los Planes Generales de Contabilidad. En este sentido, se pronunciaron las STSS de 12 de mayo de 1982 (RJ 2569/1982), de 29 de noviembre de 1983 /RJ 6733/1983), de 11 de febrero de 2002 (RJ 26639/2002) ${ }^{437}$. En consecuencia, la contabilidad suministra información del estado económico de la sociedad, pues muestra su patrimonio y sus resultados con el suministro de las cuentas anuales y, de ahí,

${ }^{432}$ Ver por todos, las concretas manifestaciones del deber de diligencia MAMBRILLA RIVERA, V., "Las concretas manifestaciones del deber de diligencia de los administradores", cit., pp. 345-383.

${ }^{433}$ Véase FONT GALÁN, J. I., El derecho de información de los administradores. Fundamentación y disciplina, Ed. Espinosa, Córdoba, 2002, p. 155.

${ }^{434}$ Tal y como ha venido proclamando nuestra mejor doctrina, véase SÁNCHEZ CALERO, F., Los administradores, cit., pp. 186-188.

${ }^{435}$ El deber de informarse comporta el deber de investigar, véanse ESTEBAN VELASCO, G., "Derecho de información del accionista", en AA.VV., Derecho de sociedades anónimas, v. I, Ed. Cívitas, Madrid, 1996, pp. 172 y ss.; FERNÁNDEZ DE LA GÁNDARA, F., Derecho de sociedades, cit., p. 738; QUIJANO GONZÁLEZ, J., "Estatuto de los administradores", RdS, núm. 27, 2006, pp. 115.

${ }^{436}$ Sobre las garantías que debe reunir la información para ser útil, véase CAÑIBANO CALVO, L., "La información contable. financiera en España: Análisis comparado de sus principios inspiradores", en Fiscalidad y Contabilidad Empresarial, Madrid, 1983, pp. 127-129.

${ }^{437}$ La contabilidad de la sociedad es la garantía de estar informado el administrador, véanse SSTS de 12 de mayo de 1982 (RJ 2569/1982); de 29 de noviembre de 1983 /RJ 6733/1983; de 11 de febrero de 2002 (RJ 26639/2002). La contabilidad cerrada exige en cada caso que se exprese con claridad y exactitud la situación patrimonial de la empresa, los beneficios obtenidos durante el ejercicio o las pérdidas sufridas y que el balance, la cuenta de pérdidas y ganancias y la memoria se redacten de manera que con la lectura pueda obtenerse una representación exacta de la situación de la compañía. 
su relevancia para el ejercicio del deber de información cuando el administrador adopte sus decisiones empresariales ${ }^{438}$.

De esta manera podemos afirmar que, la información que ofrece la contabilidad de la sociedad constituye la regla general y el instrumento que demostrará que la actuación del administrador ha sido diligente ${ }^{439}$.

Por último, especial mención merece la información que ofrecen los informes de la responsabilidad social corporativa (en adelante, RSC) que, cumplimentados con las memorias de sostenibilidad, responden a la exigencia social del desarrollo sostenible y a la transparencia de la sociedad, pues divulgan y rinden cuentas a los socios y a los grupos de interés, y además con estos informes los administradores cumplen el deber de información ${ }^{440}$.

438 "Las cuentas anuales deberán redactarse con claridad de forma que la información suministrada sea comprensible y útil para los sus usuarios al tomar su decisiones económicas, debiendo mostrar la imagen fiel del patrimonio, de la situación financiera y de los resultados de la empresa, en conformidad con las disposiciones legales", véanse BUIREU GUARRO, J., Manuel de contabilidad General, Madrid, 1983, Ed. Escuela de Inspección Financiera y Tributaria, Madrid, p. 259; CAÑIBANO CALVO, L., Contabilidad Análisis contable de la realidad económica, Ed. Pirámide, Madrid, 1991, p. 43; ESPÍN GUTIÉRREZ, C., "La cuentas anuales de la sociedad anónima como objeto del derecho de información y como objeto de aprobación por la junta general", en AA.VV., Estudios sobre órganos de las sociedades de capital, cit., pp. 566-604.

439 "La contabilidad es una ciencia de naturaleza económica que tiene por objeto producir información para hacer posible el conocimiento pasado. presente y futuro de la realidad económica en términos cuantitativos a todos los niveles organizativos, mediante la utilización de un medio especifico apoyado en bases suficientemente constatadas, con el fin de facilitar la opción de las decisiones financieras externas y las de planificaciones y control internas", véase GARRETA SUCH, J. M., La diligencia, cit., pp. 79-82.

440 "Responsabilidad social corporativa, informes integrados, informe corporativo, son el resultado de la suma de la memoria el estado financiero y los riesgos de la empresa. Y, por otro lado, la memoria de sostenibilidad que es el resultado de la suma del perfil, la estrategia y el rendimiento ambiental, social y económico de la empresa. Resulta. El informe Integrados que comprende el informe corporativo la Memoria de sostenibilidad y la visión de futuro de la empresa y que junto a su verificación tiene por objeto que un agente independiente a la entidad pueda emitir conclusiones sobre la fiabilidad y adecuación del sistema de gestión de la responsabilidad Social Empresarial o de la memoria de la RSC. El propósito de esta norma es apoyar a las organizaciones a demostrar su responsabilidad mediante el conjunto de cumplimiento de compromisos por todos los accionistas y grupos de interés, incluyendo a los gestores, Promover y potenciar una máxima transparencia”, véase Informe Anual de Gobierno Corporativo Iberdrola, 2012, D.3. Sobre ello HERNÁNDEZ PEÑASCO, R., "Particularidades en el régimen especial del gobierno de las grandes corporaciones y de la responsabilidad de los administradores: supuestos específicos", en AA.VV., Gobierno corporativo, cit., pp. 905-948. 
En definitiva, el derecho de información tiene una relevancia muy significativa en las labores de los administradores. Su importancia radica en que los administradores tienen el derecho de informarse antes de llegar a adoptar sus decisiones con carácter previo, pues, si se realizaron con una información suficiente quedarán amparados bajo la denominada regla del buen juicio empresarial ${ }^{441}$. Así pues, este derecho de información concreta el deber de diligencia y también, como veremos seguidamente, el ejercicio del deber de lealtad ${ }^{442}$.

Sin embargo, la legitimación para el ejercicio del derecho de información ha sido objeto de debate doctrinal, sobre si la atribución de este derecho era a título individual o colegiada ${ }^{443}$. Para resolver esta cuestión debemos de partir de la base fundamental de que el derecho de información es un derecho individual y, por esta razón, cada uno de los administradores ostentan el derecho a poder informarse ${ }^{444}$.

Lo anteriormente expuesto corrobora nuevamente la imprecisión en la definición del concepto de administrador de hecho establecida en el art. 236. $3 \mathrm{LSC}^{445}$, ya que el ejercicio de este derecho se encuentra supeditado por las atribuciones que individualmente tengan asignadas cada administrador ${ }^{446}$. De manera que, cuando el administrador no tiene atribuidas funciones relativas a la organización de la sociedad, no podrá obtener información sobre ella porque no se encontrará incluida en el ámbito de sus atribuciones. De ahí que, el administrador de hecho, para poder ejercitar este derecho de información, se encontraría con

${ }^{441} \mathrm{El}$ derecho de información es el requisito fundamental del en la regla de buen juicio empresarial también llamada Business Judgment Rule, véase GUERRERO TREVIJANO, C., El deber de diligencia, cit., pp. 152-182.

${ }^{442}$ Explicando esta concreción MUÑOZ PAREDES, J. M., La información de los consejeros en la Sociedad Anónima, cit., p. 60.

${ }^{443}$ Véanse DÍAZ ECHEGARAY, J. L, Deberes y responsabilidad de los administradores, cit., p. 127; SALELLES CLIMENT, J. R., El funcionamiento del consejo de administración, Ed. Vitas, Madrid. 1995, p. 344.

${ }^{444}$ Así, lo entiende MAMBRILLA RIVERA, V. M., "Las concretas manifestaciones del deber general de diligencia de los administradores", cit., pp. 362-371.

${ }^{445}$ Estableciendo esta consideración EMBID IRUJO, J. M., “Todos son (y serán) administradores”, cit., pp. 1-2.

${ }^{446}$ Para mayor estudio sobre la determinación de este derecho en relación a las funciones atribuidas a cada administrador GUERRA MARTÍN, G., "La posición jurídica de los administradores de sociedades de capital", cit., pp. 48-49. 
la tesitura de que carece de legitimación formal y, por tanto, solo cabría que lo solicitara dependiendo así del consentimiento de la sociedad ${ }^{447}$.

\section{El deber de lealtad}

El Informe Aldama ya aconsejaba la extensión de todos los deberes de lealtad al administrador de hecho, recogiéndose legalmente con la promulgación de la Ley de Transparencia ${ }^{448}$. En concreto, se introdujeron los deberes de lealtad y de fidelidad en el art. 127 bis y ter LSA.

La regulación del deber de fidelidad supuso una importante modificación, ya que con la nueva redacción parecía que se podía entender que se habían acogido las teorías “institucionalistas" ${ }^{449}$, que daban entrada a un interés distinto e independiente del defendido por las teorías contractualistas centradas en los intereses de los accionistas ${ }^{450}$. Estas últimas, a los efectos del cumplimiento del deber de lealtad, consideraban que maximizando el valor de la empresa hacia los administradores se les facilitarían las decisiones, y que el interés de los accionistas significaría una guía para actuar. Por su parte, la antagónica teoría institucionalista defendía que el mejor interés social comprendía el de los socios y otros, como el del conjunto de la empresa, y que el desarrollo económico de la sociedad afectará a

${ }^{447}$ Sobre la posible negativa por parte de la sociedad de proporcionar la información solicitada y la competencia de la oportuna entrega de la información por parte del órgano de administración, véase CONDE TEJÓN, A., "El derecho de información de los socios como medio de control de la actuación de los administradores. El difícil equilibrio para evitar los supuestos de abuso. Propuestas prácticas de mejora", en AA.VV., Estudios sobre órganos, cit., pp. 534-562.

448 El deber de lealtad es el primer deber que se proclama como el que deberá ejercer el administrador de hecho, véase DÍAZ ECHEGARAY, J. L., Deberes y responsabilidad de los administradores, cit., pp. 122 y ss.

${ }^{449} \mathrm{El}$ interés social no solo comprende los intereses de los socios, véanse POLO SÁNCHEZ, E., "Abuso o tiranía", cit., pp. 2269-2292; SÁNCHEZ RUÍZ, M., "Conflictos de intereses entre socios en sociedades de capital", $R d S$, Monografías, Navarra, 2000, pp. 61-62; SÁNCHEZ-CALERO GUILARTE, J. Creación de valor, interés social y responsabilidad social corporativa, cit., p. 17. http//www.vam es/espritus.

${ }^{450}$ La teoría contractualista concebía el interés social como la suma de los intereses particulares de sus socios, véase GARRETA SUCH, J. M., La diligencia, cit., pp. 70-74. 
las personas que crean valor. Es decir, el "interés social” consagraría la creación de valor a la sociedad ${ }^{451}$.

La Ley 31/2014 modificó la redacción del deber de lealtad establecida en el art. 227 LSC estableciendo que, "Los administradores desempeñarían su cargo como un representante leal en defensa del interés social”. Además, concretó en el art. 227.1 LSC que, "Los administradores deberán desempeñar el cargo con la lealtad de un fiel representante obrando de buena fe y en el mejor interés de la sociedad”. De este modo, se consagró el ejercicio del deber de lealtad según el mejor interés de la sociedad. El legislador optó por una postura intermedia frente a las posturas de las teorías contractualistas e institucionalistas, ya que el interés social había sido entendido como el interés de la sociedad ${ }^{452}$, y cuyas consecuencias jurídicas desencadenan en la RSC.

Sin embargo, las modificaciones de la Ley 31/2014 fueron más severas en el deber de lealtad que en el deber de diligencia, y este tratamiento diferenciador radicaba en los principios inspiradores de la reforma. Se pretendía que el ordenamiento debía ser benigno y tolerante hacía el incumplimiento del deber de diligencia y, en cambio, más estricto con el de lealtad. A estos efectos, en el art. 227.2 LSC ampliaba la sanción por la infracción del deber de lealtad, con la obligación de que el administrador deberá de indemnizar a la sociedad por el daño causado en el patrimonio social y reintegrar el enriquecimiento injusto obtenido.

${ }^{451}$ Sobre el concepto del interés social, véanse ALFONSO SÁNCHEZ, R., "Obligaciones básicas derivadas del deber de lealtad art. 228", cit., pp. 229-231; y sobre la responsabilidad social corporativa y su relación con la sociedad y con los grupos de interés, véase la explicación de MARTÍNEZECHEVARRÍA Y GARCÍA DUEÑAS, A., "La defensa del interés social", cit., pp. 128-130. También, véase STS de 10 de noviembre de 2011 (RJ 873/2011,) en torno al concepto de interés social: "La institucionalista, que considera a la sociedad anónima como una institución corporación, en la que el interés social que allí se persigue, es distinto del de sus socios, viniendo a coincidir con los intereses de los componentes de la empresa (accionistas, administradores, acreedores, trabajadores etc.)".

${ }^{452}$ Señalando esta postura intermedia que considera que "el interés social supone, con mayor frecuencia, establecer una jerarquía de intereses que sirve para tutelar unos directamente al tiempo que otros resultan indirectamente favorecidos", y que se ha adoptado por nuestro sistema Legal, véanse ALONSO UREBA, A., "El gobierno de las grandes empresas (reforma legal versus Código de conducta)", en AA.VV., El gobierno de las sociedades cotizadas, cit., pp. 105 y 106; EMBID IRUJO, J. M., Sobre el Derecho de sociedades de nuestro tiempo. Crisis económica y ordenamiento societario, Ed. Comares, Granada, 2013, p. 132 y ss.; HERNANDO CEBRIÁ, L., "Presupuestos del deber de lealtad artículo 227.1", cit., pp. 137-186; MAMBRILLA RIVERA, V., Y QUIJANO GONZÁLEZ, I., "Los deberes fiduciarios de diligencia y lealtad. En particular los conflictos de interés y operaciones vinculadas", cit., pp. 915-990, pp. 954 y ss.; PEINADO GRACIA, J. I., "Abnegación y silencio en la sociedad mercantil (apuntes sobre los conflictos de interés entre el socio y su sociedad)", en AA.VV., Derecho de Sociedades, cit., pp. 43-78. 
Para poder abordar cómo el administrador de hecho puede cumplir con el deber de lealtad será necesario partir de un análisis comparativo entre el deber de diligencia y el de lealtad ${ }^{453}$. Habrá que recordar que la diferencia entre ambos estriba en el contenido especifico de las labores de cada uno de ellos; mientras que el de diligencia tiene naturaleza dispositiva y se concreta con la obligación de informarse previamente antes de la adopción de las decisiones, en cambio, el de lealtad tiene naturaleza imperativa, por lo que la decisión viene determinada por un mínimo indisponible, que será conseguir el mejor interés de la sociedad $^{454}$.

Por otro lado, también se diferencian por su nivel de exigencia. Así, la exigencia del deber de diligencia será subjetiva al venir predeterminada por las circunstancias que concurren en el momento de la decisión del administrador y de los medios de que disponga. En cambio, el deber de lealtad es más objetivo, aunque también se podrían tener en cuenta aquellas circunstancias concretas que concurrieron en el momento del ejercicio del deber de lealtad. Estas circunstancias las podemos concretar con las personas que rodean al administrador cuando realizó el acto, el tiempo, el lugar etc. ${ }^{455}$. Sin embargo, el deber de lealtad, por ser un deber de resultado, llevará a que su actuación solo será diligente cuando el administrador de hecho adoptó la decisión con buena fe para la consecución del interés social ${ }^{456}$ y, por esta razón, las circunstancias que concurrieron en el administrador no deberían de tenerse en cuenta, ya que el grado de exigencia de este deber es más bien objetivo ${ }^{457}$.

${ }^{453}$ Esta distinción entre los deberes de los administradores, véase MAMBRILLA RIVERA, V., "Las concretas manifestaciones del deber de diligencia de los administradores", cit., pp. 351- 357; PAZ-ARES RODRÍGUEZ, C., "Anatomía del deber de lealtad”, en AA.VV., Junta general, cit., pp. 425-458.

${ }^{454}$ Véanse GARRETA SUCH, J. M., La diligencia, cit., pp. 74-76; HERNANDO CEBRIÁ, L., "Presupuestos del deber de lealtad. Artículo 227", cit., pp. 145-148.

${ }^{455}$ El principio del ordenado empresario alcanza al principio de la buena fe para obrar con lealtad véanse, DÍAZ ECHEGARAY, J., Deberes y responsabilidad de los administradores, cit., p. 231; EMBID IRUJO, J. M., Recensión al libro El deber de diligente administración en el marco de los deberes de los administradores sociales. La regla del buen juicio empresarial, cit., pp. 13-17; LLEBOT MAJÓ, J. O., Los deberes de los administradores, cit., p. 142.

${ }^{456}$ Justificando el carácter imperativo del deber de lealtad RIBAS FERRER. V., El deber de lealtad del administrador de sociedades, Ed. La Ley, Madrid, 2010, p. 396-398.

${ }^{457}$ En sentido explicando los límites del carácter imperativo del deber de lealtad, véase PORTELLANO DÍEZ, P., "El deber de evitar situaciones de conflicto de interés: entre la imperativa y la dispensa (arts. 229, 230 y 529 ter.1.h) LSC", cit., pp. 469-476. 
Consecuentemente, estos deberes se diferencian tanto por sus funciones como por las consecuencias de su incumplimiento. Si el deber de diligencia tiene la función de promover fines económicos, su incumplimiento comportaría efectos indemnizatorios; sin embargo, la función del deber de lealtad es protectora, porque por su incumplimiento originaría la invalidez del negocio jurídico realizado por el administrador ${ }^{458}$.

En otro orden de cosas, debemos señalar que el deber de lealtad presenta un contenido básico en el que se reconocen dos postulados ampliamente reconocidos por la doctrina. El primero, que el deber de lealtad consistirá en la subordinación de los intereses propios en beneficio de los ajenos y, el segundo, el que se asienta sobre el deber de disclosure o de informar, que es el que obliga al administrador a informar a la sociedad de la posición de conflicto en que se encuentra para que la sociedad le autorice el ejercicio del negocio jurídico interesado $^{459}$.

Así pues, habrá que determinar en qué medida el administrador de hecho puede cumplir, por su modo de actuar, con el deber de lealtad. Por este motivo, se convierte en labor inevitable examinar el concepto y ejercicio del deber de lealtad que ha sido tan exhaustivamente analizado por la doctrina y, a su vez, tan falto de una precisión técnica ${ }^{460}$.

${ }^{458}$ Explicando la función del deber de lealtad, véase JUSTE MENCÍA, J., "El artículo 227. El deber de lealtad", cit., pp. 367-370.

${ }^{459}$ El deber de informar de su situación conflictual como una manifestación implícita del deber de fidelidad. En este sentido, El informe Olivencia 1998 recomienda "que la normativa interna de la sociedad debería reconocer formalmente el deber del consejero de informar anticipadamente de la situación de conflicto de intereses". El Reglamento de la CNMV (1998) no establece un deber general de disclosure, si bien, refiere "al deber en supuestos concretos: consultar a la comisión de nombramientos para aceptar puestos de directivo en otra compañía, informar anticipadamente para realizar transacciones profesionales o comerciales con la compañía, deber de disclosure en operaciones indirectas". El Informe Aldama, recomendaba que los deberes de los administradores de las sociedades cotizadas deberían contemplar el deber de evitar los conflictos de intereses. De forma que los consejeros deberán desvelar al Consejo cualquier situación de conflicto de interés entre la sociedad y el accionista que ha propuesto su nombramiento, véase COSTAS COMESAÑA. J., El deber de abstención del socio en las votaciones, Ed. Tirant lo Blanch, Valencia, 1999, p. 280.

${ }^{460}$ En este sentido, el Informe Aldama postula la extensión subjetiva del deber de lealtad a aquellas personas que aún sin ostentar un aposición formal de administrador, desempeñan en la sociedad un papel de índole similar, La extensión debería alcanzar al menos a las siguientes personas (i) a las personas físicas que representan a los administradores que sean personas jurídicas (ii) a los altos ejecutivos de la sociedad aunque no ostenten la condición de consejeros (iii) a los administradores de hecho (iv) a los administradores ocultos, bajo cuyas instrucciones suelen actuar los administradores de la sociedad,8v) a los accionistas de control. Sobre la falta de precisión técnica del deber de lealtad. 


\subsection{El concepto del deber de lealtad}

La lealtad es la manifestación de la buena $\mathrm{fe}^{461}$, que es el valor que protege al administrador cuando ejerce sus labores en la sociedad con base en la fidelidad del representante de la sociedad que, obrando de buena fe, cumplirá con sus facultades en el mejor interés de la sociedad. El elemento caracterizador del deber de lealtad consistirá en que el administrador deberá anteponer los intereses de los socios a los propios. Sin embargo, se ha prestado poca atención a la hora de concretar el ejercicio de deber de lealtad ${ }^{462}$ y, por ese motivo, los administradores se han venido cuestionando cuáles eran las pautas concretas para cumplirlo, ya que tradicionalmente se limitó a un deber genérico de los que debían desempeñar su cargo como un representante leal en defensa del interés social. No obstante, el deber de lealtad se entendería cumplido si los administradores ejercitan las facultades conforme a los fines que se comprendían en sus facultades.

Ahora bien, los administradores seguían preocupados por esta falta de normas de conducta para cumplir con el ejercicio del deber de lealtad, de modo que solían acogerse al Informe Olivencia que recomendaba conductas adecuadas para cumplir con el deber de lealtad, o al Informe Aldama que definía el deber de lealtad con una serie de actos concretos que no deberían realizar los administradores.

Las actuaciones que venían recogidas en el Informe Aldama son las siguientes: Primera, el administrador para poder cumplir con el deber de lealtad debería evitar conflictos de intereses con la sociedad, que además se proyectaban hacía sus familiares más directos. Segunda, no debería utilizar para fines privados la información que poseía de la sociedad. Tercera, no podría hacer un uso indebido de los activos de la sociedad, ni valerse de su posición para obtener alguna ventaja patrimonial. Cuarta, no podría aprovecharse de las

${ }^{461} \mathrm{Al}$ respecto sobre el principio de fidelidad FERNÁNDEZ DE LA GÁNDARA, La atipicidad en derecho de sociedades, Ed. Pórtico, Zaragoza, 1977, p. 329. Resaltando la manifestación de la buena fe en los administradores, MONTÉS PENADÉS, V., "Art.7.1 CC", Comentarios a las reformas del CC, t.1, Ed. Tecnos, Madrid, 1977, pp. 356-371; PAZ-ARES RODRÍGUEZ, C., "La responsabilidad de los administradores como instrumento de gobierno corporativo", cit., pp. 67 y ss.; JORDANO FRAGA, F., La responsabilidad contractual, Ed. Cívitas, Madrid 1987, pp. 138 y 139; SÁNCHEZ RUÍZ, M., "Conflicto de intereses entre socios", cit., pp. 184 y ss., y VELOSO CARO, J., "El deber de lealtad", en AA.VV., Gobierno corporativo, cit., pp. 425-466.

${ }^{462}$ Véase FONT GALÁN, J. I., "El deber de diligente administración en el nuevo sistema de deberes de los administradores sociales", cit., pp. 71-107; QUIJANO GONZÁLEZ, J., Y MAMBRILLA RIVERA, V., "Los deberes fiduciarios de diligencia y lealtad”, cit., pp. 948 y ss. 
oportunidades de negocio que hubiera podido conocer. Quinta, el administrador cesado debería mantener en secreto toda la información que conociera de la sociedad. Sexta, debería abstenerse en aquellas votaciones cuando los acuerdos le afectaran a él directamente. Séptima, tendría la obligación de notificar los cambios de sus situaciones personales a la sociedad. Y, por último, debería informar a la sociedad del valor de las acciones y sus derivados.

Por todo lo expuesto hemos podido observar cómo el deber de lealtad no contenía un deber especial, y que su poder radicaba en la relación de confianza entre el administrador y la sociedad, ya que en nuestras legislaciones societarias pasadas habían optado para regularlo por la vía sancionadora, que implicaba solo el examen de las actividades realizadas por el administrador a posteriori. En cambio, con la LSC se ha optado por la solución preventiva, implementando una serie de conductas que los administradores no podrán realizar ${ }^{463}$. Así, las medidas introducidas por la Ley 31/2014 se incardinan en suplir el vacío legal existente. Además, la LSC menciona aquellas recomendaciones que se recogían en el Anexo III del CUBG, que propugnaban un régimen de responsabilidad más severo en torno a los dos grandes ejes de deberes de los administradores, los de diligencia y lealtad.

\subsection{Las conductas de deber de lealtad. Su concreción}

La concreción del deber de lealtad ${ }^{464}$ se establece con el ejercicio de las facultades con fines adecuados y con la obligación de que los administradores deben desempeñar sus funciones bajo el principio de la responsabilidad personal, con libertad de criterio y con independencia de las instrucciones o vinculaciones que pudieran tener con terceros ${ }^{465}$.

${ }^{463}$ Véase ESCRIBANO GÁMIR, M. C., "Humano, demasiado humano: el enriquecimiento injusto del administrador desleal", cit., pp. 1082-1084.

${ }^{464}$ La realidad del ámbito deber de lealtad viene determinado por las dos obligaciones básicas que contiene este deber la primera, evitar conflictos de interés y la segunda, nunca anteponer los intereses de la sociedad a los propios intereses de los administradores, es decir, ningún beneficio, véanse FERNÁNDEZ ALBOR BALTAR, A., "Deber de lealtad del administrador cesado". Observaciones a la sentencia de la Audiencia Provincial de Pontevedra de 18 de septiembre de 1997", $R G D$, núm. 655, 1999, pp. 3991-4011; PAZ-ARES RODRÍGUEZ, C., "Anatomía del deber de lealtad", cit., pp. 425458; PORTELLANO DÍEZ, P., "El deber de evitar situaciones de conflicto de interés entre la imperativa y la dispensa (arts. 29, 230 y 529 ter. 1.h) LSC", cit., pp. 459-561; VELOSO CARO, J., "El deber de lealtad de los administradores (artículo 226 de la Ley de Sociedades de Capital)", cit., pp. 425-466.

${ }^{465}$ Para un análisis detallado sobre las personas vinculadas a los administradores y al administrador de hecho, véanse DEL VAL TALENS, P., El administrador persona jurídica en las sociedad, cit., pp. 
En el art. 228 LSC de forma sistemática se recogen las obligaciones básicas que comprenden el ejercicio del deber de lealtad y que se encontraban reguladas en varios artículos, como el art. 229 LSC para el conflicto de intereses, y el deber de secreto en el art. 232 LSC. Su desarrollo se completará con el deber de evitar situaciones de conflicto de interés, recogido en el art. 229 LSC, en el que se describen los casos más habituales donde se presentan estos. Ahora bien, el extenso número de prohibiciones reguladas en los arts. 229 y 230 LSC se matiza con dispensas o autorizaciones, reflejando de este modo que el carácter imperativo del deber de lealtad no es absoluto.

No obstante, en la nueva regulación del deber de lealtad sigue latente la ausencia de una definición legal del concepto de conflicto de intereses, aunque la Ley 31/2014 mejoró la regulación genérica del art. 229 LSC donde simplemente se enunciaba el conflicto de intereses con la obligación de comunicar la situación de conflicto a la sociedad y de abstenerse. De ahí que para la determinación del conflicto de intereses acudiremos a la construcción doctrinal de su concepto, cuando se contraponen los intereses de la sociedad con sus propios intereses. Por ejemplo, señalamos el supuesto paradigmático de que un administrador adquiere para la sociedad bienes de su propio patrimonio personal ${ }^{466}$, entonces, para que el conflicto se origine se necesitará que concurra, no solo aquel interés personal del administrador en el acto o negocio que se persigue, sino que el interés en ese negoció ponga en peligro los intereses de la sociedad ${ }^{467}$.

Al trasladarlo al administrador de hecho, compartimos la opinión de que este podría cumplir con el ejercicio de las obligaciones básicas del deber de lealtad y, por supuesto, con el de conflicto de intereses; incluso alcanzarían a personas que se hayan vinculadas al

340-341; MATEU DE ROS CEREZO, R., Práctica de Gobierno, cit., pp. 59-85, explicando la regulación del deber de lealtad en relación al articulado anterior, véase VELOSO CARO, J., "El deber de lealtad de los administradores (artículo 226 de la Ley de Sociedades de Capital)", cit., pp. 431-437.

${ }^{466}$ Sobre la falta de regulación del concepto de conflicto de intereses del administrador, véanse GALGANO CALVO, F., El negocio jurídico. Traducción realizada por Francisco de P. Blasco Gascó y Lorenzo Prats Albentosa, Ed. Tirant lo Blanch, Valencia, 1992, p.147; JUSTE MENCÍA, J., "Artículo 227. Deber de lealtad", en AA.VV., Comentarios de la reforma, cit., pp. 361-373; PORTELLANO DÍEZ, P., "El deber de evitar situaciones de conflicto de interés", cit., pp. 477-500.

${ }^{467}$ El conflicto no existe cuando falta uno de sus requisitos necesarios: la posibilidad de lesión del interés social, véanse ALBORCH BATALLER, C., El derecho de voto de los accionistas, Ed. Tecnos, Madrid, 1997, p. 262; LECIÑENA MENDIZABAL, E., "La responsabilidad de la administrador que auto contrata en conflicto en las sociedades de capital y su equivalencia con la respuesta normativa a la auto entrada en un negocio en conflicto del patrono en las fundaciones", en AA.VV., Derecho de sociedades, cit., pp. 1342-1365. 
administrador de hecho ${ }^{468}$ en el caso particular del oculto, o al administrador de hecho, según lo establecido en el art. 236.3 LSC, que califica a esta figura como un administrador societario en sentido amplio por su modo de actuar, porque de esta manera se consigue que la responsabilidad por deslealtad sea más eficaz para los administradores que de hecho controlan y dirigen la sociedad ${ }^{469}$.

${ }^{468}$ Véase HERNANDO CEBRIÁ, L., "Presupuestos del deber de lealtad: artículo 227.1", cit., pp. 152-153.

469 Véanse las consideraciones vertidas por RODRÍGUEZ DE LAS HERAS BALLELL, T., "Requisitos para ser administrador", cit., pp. 754-756. 


\section{CAPÍTULO TERCERO}

\section{LA RESPONSABILIDAD DEL ADMINISTRADOR DE HECHO}




\section{GENERALIDADES}

En principio, la normativa que regulaba la responsabilidad de los administradores se caracterizaba por disposiciones sucintas que solían remitir al régimen general y a una serie de reglas implícitas. Sin embargo, tras diferentes reformas legislativas, se ha ido configurado un régimen jurídico independiente concretado con presupuestos materiales y con la extensión subjetiva de la responsabilidad como el núcleo central del gobierno corporativo, el cual se construye por el conjunto de los deberes de los administradores, por su régimen jurídico y por su pieza esencial representada por el estatuto jurídico de los administradores ${ }^{470}$.

A estos efectos, la Ley 31/2014, para la mejora del gobierno corporativo de las sociedades de capital, modificó el régimen de responsabilidad de los administradores introduciendo medidas en el marco jurídico de sus presupuestos e implantando un régimen más severo y eficaz que el anterior. En nuestro ámbito, destaca la extensión de la responsabilidad a la amplia definición que engloba el administrador de hecho en el art. 236. 3 LSC, "La responsabilidad de los administradores se extiende igualmente a los administradores de hecho”. Al tiempo, la medida más significativa en la exigencia de su responsabilidad fue el establecimiento de la modulación del deber general de diligencia recogido por el art. 225.1 LSC. Esta medida ha conducido a un nuevo proceso de diversificación del régimen de la responsabilidad, ya que la exigencia de la diligencia debida a los administradores se graduará atendiendo a las funciones que se le atribuyen a cada uno de ellos y a la naturaleza del cargo asignado ${ }^{471}$.

Junto a la responsabilidad general de los administradores en el ámbito societario también debemos referirnos a la llamada responsabilidad por obligaciones sociales, que nace por el incumplimiento de las obligaciones legales establecidas en el art. 363 LSC bajo los

${ }^{470}$ Los requisitos tradicionales para exigir responsabilidad a los administradores consisten: en un acto contrario a la Ley, los estatutos o a los deberes inherentes al cargo que cause daño a la sociedad o a terceros con una relación de causalidad entre el daño y el resultado producido RODRÍGUEZ DE LAS HERAS BALLELL, T., "Requisitos para ser administrador", cit., pp. 735-736. Los presupuestos de la responsabilidad se han ido extendido a otras figuras como los altos directivos, cualquiera que sea su denominación, a las personas que se consideren administradores de hecho y al representante de la persona jurídica administradora, véase GRIMALDOS GARCÍA, M". I., "Presupuestos y extensión subjetiva de la responsabilidad", cit., pp. 307-328.

${ }^{471}$ Explicando la modificación del régimen de los deberes de los administradores y su influencia en el régimen de la responsabilidad MÁS-GUINDAL GARCÍA, J., "La responsabilidad de los administradores", en AA.VV., Gobierno Corporativo, cit., pp. 785-811. 
presupuestos del art. 367 LSC. De este modo, los administradores responderán personalmente por las deudas de la sociedad si omitieran la obligación legal de convocar junta general para adoptar el acuerdo de disolución, cuando se encuentre la sociedad en causa de disolución o cuando omitan el deber de solicitar el concurso de la sociedad cuando sea procedente. Este tipo de responsabilidad por obligaciones sociales contiene un régimen jurídico específico previsto en el art. 367 LSC y, si bien, no menciona al administrador de hecho, cabe su aplicación por su calificación como administrador cuando tiene el control y el poder de dirección en la sociedad a través de la toma de sus decisiones para conseguir el mejor interés social $^{472}$.

En otro orden de cuestiones, destacar que en sede concursal hay que tener en cuenta que se prevé un régimen jurídico completamente distinto al régimen de responsabilidad general de los administradores. Se distinguen así entre dos tipos de responsabilidades: la primera, de naturaleza indemnizatoria o por daños recogida en el art. $172.2,3^{\circ} \mathrm{LC}$ y que obliga a los administradores, que han sido afectados en la pieza de calificación del concurso culpable, a indemnizar por los daños y perjuicios causados y a devolver los bienes o derechos obtenidos indebidamente de la masa de acreedores. Y, la segunda, la responsabilidad por la cobertura del déficit patrimonial prevista en el art. 172 bis LC, que nace cuando el patrimonio de la concursada no resulta suficiente para poder saldar las deudas de la sociedad en el concurso calificado como culpable ${ }^{473}$. En esta sede, resaltar que el administrador de hecho ha sido recogido como responsable expresamente en el ámbito de la responsabilidad concursal, aunque su análisis requerirá un estudio independiente.

Cabe destacar que, si bien no se va a explicar la responsabilidad del administrador de hecho en el ámbito penal, no obstante, conviene indicar que el art. $31 \mathrm{CP}$ prevé que resultará

${ }^{472}$ En esta responsabilidad expresamente no aparece el administrador de hecho, pero deberá cumplir con los deberes legales para que no tenga que responder personalmente por las deudas de la sociedad, véanse ALFARO ÁGUILA-REAL, J., "Artículo 225. El deber de diligencia", cit., pp. 313-314; BELTRÁN SÁNCHEZ, E., La responsabilidad de los administradores por obligaciones sociales”, en AA.VV., La responsabilidad, cit., pp. 301-352; DÍAZ RUÍZ, E., "La coordinación de los administradores solidarios de las sociedades de capital como manifestación del deber de diligencia", cit., pp. 1003-1005; RECAMÁN GRAÑA, E., "Algunas reflexiones en torno al inicio del cómputo del plazo de la prescripción de la acción de responsabilidad de los administradores por obligaciones sociales", en AA.VV., Estudios sobre órganos, cit., pp. 1258-1270.

473 El administrador de hecho se reconoce responsable expresamente en el ámbito de la responsabilidad concursal, véanse PARDO PARDO, R. M., El nuevo régimen de responsabilidad, cit., pp. 58-59. 
responsable con arreglo a la siguiente redacción, "El que actúe como administrador de hecho o de derecho de una persona jurídica, o en su nombre o representación legal o voluntaria de otro, responderá personalmente, aunque no concurran en él las condiciones, calidades o relaciones que la correspondiente figura de delito o falta requiera para poder ser sujeto activo del mismo, si tales circunstancias se dan en la entidad o persona en cuyo nombre o representación obre”. Esa responsabilidad penal no se aplicará automáticamente al administrador de hecho de una manera objetiva, pues siempre se deberá probar una acción por su parte que contribuya en el resultado del tipo de delito que, a modo de $v$. gr., señalamos el caso del delito fiscal por la defraudación de la sociedad en el impuesto de sociedades ${ }^{474}$.

Y, por otro lado, en el art. 31.1. bis CP se contempla la responsabilidad de la persona jurídica por los delitos cometidos en nombre o por cuenta de la misma, por los administradores de hecho o de derecho y por los cometidos por los empleados; en este caso concreto, los administradores de hecho y los de derecho deben supervisar y vigilar la actividad de la sociedad, ya que en nuestra legislación penal se contempla la prevención de delitos en el art. 31 bis. 2 CP mediante modelos de organización que incluyen medidas de vigilancia y control. Estos modelos deberán ser impuestos por el órgano, es decir, si el delito se cometió por un administrador el modelo de prevención deberá reunir unos requisitos distintos al modelo de prevención de los delitos de los empleados, y así, la sociedad quedará exenta de responsabilidad penal si se adoptó un sistema de compliance antes de la comisión de los delitos ${ }^{475}$. De esta forma, lo que se penaliza no es que el administrador no ha vigilado al concreto autor del delito, sino que la empresa no ostentaba el conjunto de medidas organizativas para impedir que sus administradores o empleados pudieran delinquir cuando estos habían realizado un acto delictivo.

${ }^{474} \mathrm{El}$ administrador de hecho, como es sabido, fue expresamente reconocido como responsable en el ámbito penal, incluso, antes que en el societario, véase GUTIÉRREZ RODRÍGUEZ, M.., "La responsabilidad penal de los administradores de sociedades mercantiles, en AA.VV., La responsabilidad de los administradores, cit., pp. 445-509.

${ }^{475}$ Los sistemas de cumplimiento, entre otros, corporate codes, compliance programs, codes of conduct, corporate responsibility, risk management, constituyen los mecanismos de control social empresarial aunque y, a su vez, han supuesto un aumento del poder de los administradores y directivos en las empresas debido a que con la incorporación de estos sistemas a los administradores se les legitima para establecer medidas de control sobre los trabajadores, véanse ALONSO DE ESCAMILLA, A., "La responsabilidad penal de los administradores de sociedades mercantiles. Una aproximación desde la perspectiva del compliance", en AAVV, Gobierno corporativo, cit., p. 884; NIETO MARTín, A., Problemas fundamentales del cumplimiento normativo en el derecho penal. Compliance y teoría del derecho penal, Ed. Marcial Pons, Valencia, 2013, pp. 25 y 26. 
En relación a nuestro objeto de estudio, el administrador de derecho o de hecho impulsará la adopción del modelo de prevención establecido en el art. 31 bis.2 CP, y a tales efectos deberán ser ejecutados con eficacia antes de la comisión del delito. En este sentido, los modelos de organización incluyen las medidas idóneas para prevenir el riesgo de su comisión conforme a los requisitos establecidos en el citado precepto. Así que los administradores y los administradores de hecho serán los responsables de no impulsar esas medidas de control. No obstante, para ser apreciada la eximente de responsabilidad penal se necesitará, tal y como requiere el art. 31bis.2, $2^{\mathrm{a}} \mathrm{CP}$, que exista un órgano encargado de la supervisión del funcionamiento y del cumplimiento de dicho modelo, el cual tiene que ser supervisado por un órgano independiente denominado compliance officer. En este supuesto, de nuevo aparece la responsabilidad de los administradores de hecho, pues para las sociedades de pequeñas dimensiones la ley establece que las funciones de supervisión, que vienen establecidas en el citado art. 31 bis.2. $2^{\text {a }} \mathrm{CP}$, pueden ser realizadas por aquellas personas que están autorizadas a presentar la cuenta de pérdidas y ganancias abreviada y, en base a ello, las funciones de previsión compliance officer podrán ser asumidas por el órgano de administración. Sin embargo, para el resto de sociedades el órgano de supervisión del funcionamiento y cumplimiento del modelo de prevención deberá ser un órgano con poderes autónomos de incitativa, como la comisión de auditoría o, en su caso, una comisión especializada ${ }^{476}$.

\section{LA EXTENSIÓN SUBJETIVA DE LA RESPONSABILIDAD DE LOS ADMINISTRADORES AL ADMINISTRADOR DE HECHO}

\section{La evolución de la exigencia de la responsabilidad al administrador de hecho}

La evolución de los presupuestos de la responsabilidad de los administradores ha sido fruto de una larga tarea legislativa que tuvo su comienzo con aquella configuración que consideraba a los administradores como mandatarios, en el art. 265 del Código de Comercio

\footnotetext{
${ }^{476}$ Un análisis detallado del contenido y alcance del papel de los administradores en la prevención de delitos, véanse CAZORLA GONZÁLEZ-SERRANO, L, "Administradores sociales, deber de diligencia y programas de cumplimiento penal (una perspectiva mercantil del cumplimiento normativo)", en AA.VV., Derecho de Sociedades Revisando el derecho de sociedades, cit., pp. 12591261; MARTÍNEZ MARTÍNEZ, D. F. Y SAÉZ NICOLÁS J. R., "El deber de diligencia y responsabilidad de los administradores de las sociedades no cotizadas a la luz del art. 31 bis del Código Penal o la obligación de implementar programas de compliance penal" en AA.VV., Derecho de Sociedades Revisando el derecho de sociedades, cit., pp.1263-1284.
} 
de 1828. En este Código no se regularon presupuestos para exigir la responsabilidad a los administradores limitándose a señalar que, "puede constituirse la compañía mercantil, creándose un fondo por acciones determinadas para girarlo sobre uno o muchos objetos que dé nombre a la empresa social, y cuyo manejo se encargue a mandatarios o administradores amovibles a voluntad de los socios, y esta compañía es la que lleva el nombre de anónima" ${ }^{477}$. Al mismo tiempo, en el art. 277 del citado CCom se añadía que sólo respondían frente a la sociedad cuando no desempeñaran bien sus funciones: "Los administradores de las sociedades anónimas se nombrarán en la forma que prevengan sus reglamentos y no son responsables personalmente, sino del buen desempeño de sus funciones. Con el mismo carácter, el CCom de 1885 regulaba la responsabilidad en una única disposición, en su art. 156, que seguía contemplando dicha responsabilidad como mandatarios. En él se decía que, “Los administradores de las Compañías Anónimas son sus mandatarios, y, mientras observen las reglas del mandato, no están sujetos a responsabilidad personal ni solidaria por las operaciones sociales". Así pues, los administradores respondían por las infracciones de las reglas del mandato, pero no respondían por el daño ocasionado a terceros que eran extraños a la sociedad ${ }^{478}$.

De la deficiente regulación de la responsabilidad se hizo eco la doctrina ${ }^{479}$, porque este régimen no resultaba precisamente muy adecuado, ya que los administradores estaban protegidos cuando realizaban sus operaciones en nombre de la sociedad. Esta situación cambió radicalmente cuando la SA dejó de regularse en el CCom de 1885 y pasó a su regulación especial en la Ley sobre Régimen Jurídico de las sociedades anónimas de 1951. Quedaron de este modo abandonadas las reglas del mandato y se instauró por fin un genuino régimen jurídico de responsabilidad de los administradores con un vínculo orgánico con la

${ }^{477}$ Véase GIMENO-BAYÓN COBOS, R. Y ORELLANA CANO, C., "La responsabilidad de los administradores. Comentario al artículo 133 de la Ley de Sociedades administradores Anónimas", en AA.VV., Órganos de la sociedad de capital (Dir. GIMENO-BAYÓN COBOS Y GARRIDO ESPÁ), Ed. Tirant Lo Blanch, Valencia 2008, pp. 934-1002.

${ }^{478}$ En torno a cómo ha sido la evolución de la responsabilidad a de los administradores desde sus inicios, véanse DÍAZ ECHEGARAY, J. L., Deberes y responsabilidad de los administradores, cit., pp. 27-34. Y para los antecedentes del art. 156 CCom, véase QUIJANO GONZÁLEZ, J., La responsabilidad civil de los administradores, cit., pp. 119-123.

${ }^{479}$ Ver por todos GARRÍGUES DÍAZ-CAÑAVATE, J., Tratado de Derecho mercantil", t. I, vol. $2^{\circ}$, Madrid, 1947, pp. 1023 y ss.; GIRÓN TENA, J., "La responsabilidad de los administradores de la sociedad anónima en el derecho español”, $A D C, 1959$, pp. 419-450. 
sociedad $^{480}$. Así, el art. 79 LSA de 1951 recogía los presupuestos con base en el daño causado a la sociedad a los accionistas y a los acreedores sociales; sin embargo, el grado de exigencia de la responsabilidad se siguió manteniendo con el mismo nivel que venía establecido en el art. 144 CCom por una actuación maliciosa, abuso de facultades o negligencia grave. En concreto, se establecía, que, "Los administradores desempeñarán su cargo con la diligencia de un ordenado comerciante y de un representante leal, y responderán frente a la sociedad, frente a los accionistas y frente a los acreedores del daño causado por malicia, abuso de facultades o negligencia grave”. Además, dispuso que estarían exentos de responsabilidad, “cuando hubieran salvado su voto en aquellos acuerdos que hubieran producido el daño" 481 .

También, para poder exigir responsabilidad a los administradores se reguló la acción social en el art. 80 LSA, que se activaría por la sociedad, y con la acción individual para ser ejercitada por los socios o por terceros ajenos a la sociedad en el art. 81 LSA. Las denominaciones que se emplearon para el ejercicio de estas dos acciones era una terminología ya usada por parte de nuestra doctrina. En concreto, el ejercicio de la acción social servía para reparar el daño causado por los administradores a la sociedad y la acción individual para resarcir a los socios y a terceros ajenos a la sociedad por los actos que lesionarán directamente sus intereses. Así que, la regulación de estas dos acciones determinó el ejercicio legal para poder exigir los daños causados por los administradores, colmándose las lagunas que presentaba la legislación anterior respecto al ámbito subjetivo de la responsabilidad y sus presupuestos $^{482}$. Sin embargo, tal y como quedaron regulados los presupuestos de la responsabilidad en el art. 79 LSA, todavía se mantenía un nivel muy alto para exigirla, pues solo respondería cuando el daño se hubiera realizado mediante una conducta maliciosa o por el abuso de las facultades y por negligencia grave. Por su parte, el legislador justificaba el amparo a los administradores por los riesgos que acarreaba el someterlos a otras reglas. Este planteamiento también se mantendría en la LSRL, de 17 de julio de 1953.

${ }^{480}$ Sobre la evolución de las clases de acciones para la exigencia de la responsabilidad, véanse EMBID IRUJO, J, M., "Medidas de defensa de una sociedad mercantil frente a una acción exterior de obtención de control. Las cláusulas anti-opa", RDBB, núm. 39, 1990, pp. 535-548; MUÑOZ PAREDES, A., Tratado judicial de la responsabilidad de los administradores, Ed. Aranzadi, Cizur Menor, 2005, pp. 39-78.

${ }^{481}$ Explicando que el régimen de responsabilidad por culpa grave de los administradores es más favorable en la LSA de 1951 que con respecto al CCom de 1885, véase VICENT CHULIÁ, F., Introducción al Derecho mercantil, cit., pp. 399-340.

${ }^{482}$ Con detalle sobre la evolución de los presupuestos, véase GARRIGUES DÍAZ-CAÑAVATE J., Y URÍA GONZÁLEZ, R., Comentario a la Ley de sociedades anónimas, t. II, Instituto de estudios políticos, Madrid, 1953, pp. 156-157. 
Así pues, hasta esta fecha ser administrador era un cargo fácil, sin riesgo, rentable y seguro, que conllevaba toda una serie de ventajas y casi ningún inconveniente, pues con aquel marco legislativo la responsabilidad de los administradores era una cuestión que solo se planteaba por el incumplimiento lesivo de ciertos deberes, apenas esbozados en la Ley. El siguiente hito legislativo fue la promulgación de la Ley 19/1989, de 25 de julio, aprobada conforme con las directrices que impartía la Unión Europea en materia de sociedades. Esta reforma sería determinante en la evolución de responsabilidad de los administradores debido a que cambió el nivel de exigencia que venía establecido en el art. 72.2 LSA de 1951, así, "los administradores responderán por los actos contrarios a la ley o a los estatutos o por los realizados sin la diligencia con la que deben desempeñar el cargo”.

Seguidamente, tal y como preveía la disposición final primera de la Ley 19/1989, en el plazo de un año se aprobó, por el RDL 1564/ 1989, de 22 de diciembre, el TRLSA, que supuso la reforma de los arts. 79 y 80 LSA. El salto cualitativo fue muy relevante, ya que tomó aquellas bases de la LSA de 1951 por inspiración de otros ordenamientos del derecho comparado, entre ellos, el Código italiano de 1942, y así en tres epígrafes se recogieron tres nuevos preceptos. El primer epígrafe configuró el art. 133 LSA, que recogía los presupuestos con la misma redacción que el derogado art. 79.2 LSA de la reforma parcial de1989; en el segundo, se incorporó la disciplina de la acción social en el art. 134 LSA $^{483}$ y, en el tercero, introdujo la acción individual en el art. $135 \mathrm{LSA}^{484}$ con la misma redacción establecida en los

${ }^{483}$ La LSA distingue la acción social prevista en el art. 134 LSA que se caracteriza porque el daño se produce a la sociedad y la acción individual en el art. 135 LSA donde el daño se produce al individuo. La acción social podrá ejercitarla: 1. Quien se considere dañado, 2. El ente social, previo acuerdo de la junta, 3. Los accionistas y los acreedores, véanse HUERTAS VIESCA, M .I., "Acción social de responsabilidad de los administradores por los socios y desistimiento (Comentario a la STS, 1ª 30/117200)", RDM, núm. 243, 2002, pp. 295 y ss.; JUSTE MENCÍA, J., "Legitimación subsidiaria para el ejercicio de la acción social”, en AA.VV., La responsabilidad de los administradores en las sociedades mercantiles, cit., pp. 121-154; QUIJANO GONZÁLEZ, J., "La acción social de responsabilidad contra los administradores: el acuerdo y legitimación para ejercitarla. Comentario a la sentencia 380/2012, de 5 de diciembre de 2012, de la Audiencia Provincial de Madrid, Sección 28", RDM, núm. 290, 2013, pp. 347 y ss.; SALDAÑA VILLOLDO, B., "Acciones de responsabilidad: Artículos 239 a 241 bis", en AA.VV., Régimen de deberes y responsabilidad. cit., pp. 363-423. A la luz de nuestra jurisprudencia la acción social SSTS de 31 de diciembre de 2002 (RJ 1290/2002); de 4 de abril de 2003 (RJ 322/2003); de 5 de octubre de 2006 (RJ 968/2006); de 8 de octubre de 2007 (RJ 1076/2007; de 20 de julio de 2010 (RJ 472/2010).

${ }^{484}$ Esta acción individual no es para la reintegración patrimonial a la sociedad, que no es la lesionada, sino que tiende a establecer una indemnización a favor de los socios, acreedores y terceros, por los actos que sean consecuencia de un incumplimiento culposo en el ejercicio del cargo de administrador. Así, las causas que originan la acción de responsabilidad no es una lista cerrada, pues la responsabilidad surge de todo acto u omisión, véanse ALFARO AGUILA-REAL, J., "La llamada acción individual de responsabilidad contra los administradores", $R d S$, núm. 18, 2002, pp. 45-47; 
arts. 80 y 81 de la LSA de 1951. Con arreglo a ello, la acción social e individual adquirieron carta de naturaleza legal en el art. 133.1 LSA, desapareciendo así el criterio cualificado de imputación que venía exigido en la LSA de 1951, que no era otra que la malicia, la negligencia grave o el abuso de facultades. Con la desaparición de ese criterio se abrió la vía para permitir que los jueces sustituyeran el nivel de exigencia de la responsabilidad por la discrecionalidad en sus decisiones, que necesariamente se reconocía en la gestión de los administradores.

Al tiempo, se configuró otra responsabilidad especial de los administradores por las deudas de la sociedad en el art. 262.5 LSA y en el art. 105.5 LSRL, de 23 de marzo de $1995^{485}$. Esta especial responsabilidad puso fin a la "plácida" vida de los administradores que, a partir de entonces, pasarían a responder personalmente por las deudas sociales de forma solidaria con la sociedad si omitieran el deber de convocar a la junta general en el plazo de dos meses desde que la sociedad se encontraba en causa de disolución. La novedad era profunda, pues se pasó de una responsabilidad de corte aquiliana, social o individual, que exigía acreditar que el administrador había causado daño y que era de difícil prueba, a una responsabilidad objetiva y de carácter sancionador, porque los administradores responderían de las deudas posteriores al incumplimiento de la disolución e, incluso, de las anteriores al nacimiento de la causa de disolución. De esta forma, la nueva regulación trajo como consecuencia que, en lo sucesivo, se podría exigir a los administradores responsabilidad, acumulando la acción social y la individual, así como la responsabilidad por obligaciones sociales $^{486}$.

ALCALÁ DÍAZ, M. A., "Acción individual de responsabilidad frente a los administradores (STS de 21 de mayo de 1992)", RdS, núm. 1, 1993, pp. 166 y ss.; ALONSO UREBA, A., "Presupuestos de la responsabilidad social de los administradores de una sociedad anónima", RDM, 1991, cit., pp. 639 y ss.; ESTEBAN VELASCO, G., "La acción social y la acción individual de responsabilidad contra los administradores de las sociedades de capital", en AA.VV., la responsabilidad de los administradores (Dir. BOLAS ALFONSO), Estudios de Derecho Judicial, núm. 24, 1999, pp. 57-130. Y la coordinación con otras acciones de responsabilidad de los administradores, GIMENO-BAYÓN COBOS, R., Y ORELLANA CANO, N. A., "La responsabilidad de los administradores. Comentarios al art. 133 de la Ley de sociedades Anónimas", cit., pp. 934-102; MARÍN DE LA BÁRCENA, F., "La acción individual de responsabilidad de los administradores de sociedad anónima frente a socios y terceros", $R d S$., núm. 13, 1999, pp. 304 y ss.; REGLERO-CAMPOS, L. F., Tratado de Responsabilidad Civil, Ed. Aranzadi, Cizur Menor, 2002. p. 67 y ss.

${ }^{485}$ Explicando el marco legislativo de la responsabilidad de los administradores por las deudas sociales, véase BELTRÁN SÁNCHEZ, E., "Responsabilidad de los administradores por obligaciones sociales", en AA.VV., La responsabilidad de los administradores, cit., pp. 213-259. 
La culminación de la responsabilidad de los administradores y, en particular, con respecto a la responsabilidad del administrador de hecho, se produjo con las reformas del TRLSA, operadas por la Ley de 26/2003, de 17 de julio, de Transparencia, que modificó el régimen de la responsabilidad introduciendo tres importantes novedades en el art. 133 LSA. La primera, introdujo las omisiones de los administradores y se determinaron los presupuestos materiales, referenciando que la conducta u omisión causante del daño debería ser contraria a la Ley o a los estatutos, precisando la responsabilidad por el incumplimiento de los deberes inherentes al desempeño del cargo, y dejando la alusión al incumplimiento por diligencia. La segunda, fue nuestro objeto de estudio, pues supuso el reconocimiento del administrador de hecho en el ámbito de responsabilidad de los administradores previsto por el art.133. 2 LSA y, desde entonces, ya se podía exigir responsabilidad a los administradores de hecho con el ejercicio de las acciones sociales e individuales, aunque la Ley olvidó delimitar qué debía entenderse por administrador de hecho, tal y como se trató de forma detallada en el primer capítulo de este trabajo.

Posteriormente, la Ley 19/2005, de 14 de noviembre, sobre SAE domiciliadas en España, reformó los arts. 262.5 LSA y 105.5 LSRL de 1995 con el establecimiento de la presunción de que las deudas sociales sólo serían exigibles desde la fecha posterior al acaecimiento de la causa de disolución de la sociedad, salvo que los administradores acreditasen que era de fecha anterior.

Una nueva reforma en sede de responsabilidad de los administradores se produjo con la LSC. En particular, el art. 236. 1 LSC recogió al administrador de hecho y al de derecho en los presupuestos de la responsabilidad bajo la siguiente redacción: "Los administradores de derecho o de hecho como tales, responderán frente a la sociedad, frente a los socios y frente a los acreedores sociales del daño que causen por actos u omisiones contrarios a la ley o a los estatutos o por los realizados incumpliendo los deberes inherentes al desempeño del cargo". Desde este momento se consagró la plena equiparación del administrador de hecho con el administrador de derecho, aunque el concepto de administrador de hecho seguía sin conceptuarse.

En este contexto, el administrador de hecho no planteaba problema para la exigencia de su responsabilidad, pues esta figura era ya un sujeto activo de la responsabilidad en virtud del art. 236.1 LSC, mediante el ejercicio de la acción social que pasó a ser regulada en los arts. 
238 a 240 LSC, y la acción individual en el art. 241 LSC. El problema se planteaba respecto al ejercicio de la acción de responsabilidad solidaria por obligaciones sociales de la sociedad que se reguló en el art. $367 \mathrm{LSC}^{487}$, porque en este precepto no se mencionaba al administrador de hecho, al igual que ocurría en el derogado art. 262.5 LSA.

El siguiente hito legislativo en materia de responsabilidad lo encontramos con el APCM, que fue aprobado el día 30 de mayo de 2014 sobre el texto de la PCM, de 17 de junio de 2013, ya que en los presupuestos desencadenantes de la responsabilidad se añadió que el administrador resultaría responsable del acto realizado si se ejerciera con dolo o de culpa y, en el aparatado 2 del art. 215-14 APCM se incorporó la presunción de la culpa cuando el administrador realizara actos contrarios a la Ley o los estatutos ${ }^{488}$. Se regula la acción social en art. 215-15 APCM y la acción individual en el art. 215-19 APCM, ambas de corte indemnizatoria y de carácter subjetivo ${ }^{489}$.

La extensión de la responsabilidad al administrador de hecho culmina con la reforma acometida por la Ley 31/2014, en el art. 236. En concreto, en el apartado 1 del citado artículo se regulan los presupuestos para la exigencia de la responsabilidad; en el segundo, la exención de la responsabilidad de los administradores; en el tercero, se identifican las personas que podían alcanzar la calificación de administrador de hecho; en el cuarto, se extiende la responsabilidad a los altos cargos de dirección de la sociedad si no existe delegación de facultades del consejo en uno o varios consejeros delegados; y, en el quinto, se extiende a la persona física representante de la persona jurídica administradora de la sociedad. Solucionó así la cuestión controvertida que la propia doctrina se venía cuestionando sobre la calificación jurídica del representante, al disponer que la persona física designada para el ejercicio de las funciones inherentes al cargo debería reunir los requisitos legales para la designación de un administrador societario. También la Ley 31/2014 aclaró otra duda que igualmente perturbaba

${ }^{487}$ Explicando este problema en la Ley sobre el origen de la responsabilidad por obligaciones sociales, véase BELTRÁN SÁNCHEZ, E., "La responsabilidad de los administradores por obligaciones sociales", en AA.VV., La responsabilidad de los administradores, cit., pp. 301-308; MARTÍNEZ SANZ, F., "Los administradores responsables", cit., pp. 69-73.

${ }^{488}$ Sobre la responsabilidad por deudas de la sociedad en el nuevo APCM, para mayor estudio, véase QUIJANO GONZÁLEZ; J., "Sociedades mercantiles: disolución; sociedades cotizadas", en AA.VV., Hacia un nuevo Código Mercantil, cit., pp. 193-211.

${ }^{489}$ Acerca de las nuevas disposiciones en el APCM sobre la responsabilidad de los administradores, véase GARCÍA-CRUCES GONZÁLEZ, J. A., "Disposiciones sobre las sociedades mercantiles", en AA.VV., Hacia un nuevo Código Mercantil, cit., pp. 139-169. 
a la doctrina, y que tenía que ver con la responsabilidad del represente, pues vino a confirmar que este responderá solidariamente con la persona jurídica administrador al equipararse automáticamente como un administrador independientemente de su posible consideración, según el caso, como administrador de hecho ${ }^{490}$.

Con la extensión subjetiva de la responsabilidad de los administradores, su régimen jurídico se ha convertido en disciplinario y mucho más duro que el régimen anterior. Esta mejor disciplina trae su causa de la extensión de la responsabilidad a un círculo muy amplio de destinatarios y, muy especialmente, al administrador de hecho oculto con el fin de garantizar el control de la actuación de los administradores cuando gestionan la sociedad. Todo ello se traduce en que el administrador de hecho se convierte en un instrumento decisivo que servirá para establecer una responsabilidad mucho más eficaz ${ }^{491}$, ya que entre las personas que alcanzarían la aplicación de la responsabilidad se encuentra, sobre todo, aquella que actúa influenciando en los administradores de una manera continua y determinante, como el socio mayoritario o, incluso, la sociedad dominante si ejerce una influencia decisiva en los administradores de las filiales del grupos ${ }^{492}$. Esto es, la responsabilidad se extiende a todas aquellas personas que ejerzan un control efectivo en la administración de la sociedad, ya sea de forma externa u oculta ${ }^{493}$.

Por tanto, la extensión subjetiva de la responsabilidad de los administradores se convirtió en un pilar que conducía a restablecer el equilibrio entre los administradores y la sociedad, porque responderán frente a la sociedad los socios o los acreedores sociales. Y, por otra parte, los presupuestos de la responsabilidad de los administradores se han convertido en factores decisivos para que las personas calificadas como administradores de hecho se ajusten a sus presupuestos cuando resulten responsables por su modo de actuar ${ }^{494}$.

\footnotetext{
${ }^{490}$ En torno a la naturaleza jurídica del representante de la persona jurídica administradora, véase BRENES CORTÉS, J., "La responsabilidad del representante persona física”, cit., pp. 83-89.

${ }^{491}$ En este sentido, véanse EMBID IRUJO, J. M., "Todos son y (serán) administradores", cit., pp. 13; SÁNCHEZ CALERO-GUILARTE, J., "Administrador de hecho, hay que probarlo", cit., pp. 1-4.

${ }^{492}$ Véase MORENO SERRANO, E., "La responsabilidad de la sociedad matriz como administrador de hecho", cit., pp. 1335-1341.

${ }^{493}$ El alcance del ejercicio de la responsabilidad, véase CAMPUZANO LAGUILLO, A. B., "La acción de responsabilidad (artículo 238 a 240 de la ley de sociedades de capital)", en AA.VV., Gobierno corporativo, cit., pp. 767-814.

${ }^{494}$ Sobre el equilibrio entre el poder de dirección y la responsabilidad de los administradores, véase RODRÍGUEZ DE LAS HERAS BALLELL, T., "Requisitos para ser administrador", cit., pp. 746-748.
} 
No obstante, consideramos que a los diferentes tipos de administradores de hecho no se les podrá imponer el mismo nivel de exigencia que a los administradores formales ${ }^{495}$, ya que por ser un hecho no está dotado de funciones específicas, y por esta razón su responsabilidad variará atendiendo a sus posibilidades de actuación para poder cumplir con las obligaciones de los administradores en el caso enjuiciado ${ }^{496}$.

También consideramos que, los distintos tipos de responsabilidad solo alcanzarían al administrador de hecho en su manifestación oculta, siempre que se demostrara que el poder de dirección lo detenta aquella persona que viene dirigiendo a los administradores de derecho que cumplen con sus órdenes de forma sistemática y continuada. Para alcanzar esta consideración nos apoyamos en los argumentos de una parte de nuestra doctrina cuando afirma que el administrador de hecho oculto resultaría responsable al omitir la orden a los administradores formales para que convoquen la junta general, para que se adopte el correspondiente acuerdo de disolución de la sociedad o, en su caso, cuando se omitió la orden dirigida a solicitar el concurso en caso de que la sociedad se encuentre en un estado de insolvencia $^{497}$.

Por otra parte, los anteriores antecedentes nos conducen a solventar una cuestión fundamental sobre cómo podremos determinar el nivel de exigencia al administrador de hecho si carece de designación formal. Para resolver esta cuestión opinamos que se tendría que implementar un régimen jurídico específico para exigir la responsabilidad al administrador de hecho en cualquiera de sus manifestaciones y, sobre todo, que fuera independiente del régimen general de responsabilidad de los administradores formales, ya que la exigencia de la responsabilidad de estos se encuentra presidida por la naturaleza del cargo asignado a cada administrador y por las funciones que tienen atribuidas; lo que se traduce en que el administrador de hecho queda en desventaja con respecto a los formales. En concreto, porque los administradores de derecho solo responderán frente a la sociedad, los socios o los acreedores sociales del daño causado en función de la naturaleza del cargo y atendiendo a las

\footnotetext{
${ }^{495}$ En este sentido y defendiendo estas consideraciones, véase PARDO PARDO, J. M., El nuevo régimen de responsabilidad, cit., pp. 224-225.

496 En este sentido nos apoyamos en nuestra tradicional doctrina sobre la exigencia de la responsabilidad al administrador de hecho, véase LATORRE CHINER, N., "El concepto de administrador de hecho", cit., p. 895.

${ }^{497}$ Esta es la corriente que defiende parte de la doctrina, véase HERNANDO CEBRIÁ, L., "El deber de lealtad", cit., pp. 148.
} 
funciones atribuidas. Por tanto, el legislador nuevamente perdió la oportunidad de regular de forma precisa un régimen jurídico de responsabilidad para el administrador de hecho en el art. $236 \mathrm{LSC}^{498}$.

No obstante, todas estas cuestiones serán abordadas cuando desarrollemos en los epígrafes siguientes un estudio detallado del análisis comparativo de los diferentes tipos de responsabilidades y del régimen jurídico específico que se contempla en cada una de ellas, con el fin de que podamos clarificar si un administrador de hecho podría resultar responsable para resarcir por los daños que han sido causados al haber incumplido los deberes a los que se encuentran sometidos los administradores.

\section{Los presupuestos materiales de la responsabilidad de los administradores en el de hecho}

\subsection{Delimitación previa}

Como es sabido, los presupuestos materiales de la responsabilidad de los administradores se contemplan en el art. 236.1 LSC. El primero, que exista un acto u omisión contrario a la ley o los estatutos, o incumpliendo los deberes inherentes al desempeño del cargo; el segundo, que el acto deberá causar un daño; el tercero, que concurran los elementos intencionales de dolo o culpa en cualquiera de sus grados, es decir, ya sea por culpa grave o leve; y, el cuarto, una relación de causalidad entre el acto ilícito y el daño producido a la sociedad, a los socios o a los acreedores sociales ${ }^{499}$.

En definitiva, los presupuestos se regulan en la LSC obedecen a un planteamiento subjetivo que se aparta del modelo objetivo anterior que no exigía culpa, además de eliminar la distinción entre administradores de derecho y de hecho. Así, se establece que, "los administradores responderán frente a la sociedad, frente a los socios y frente a los

498 Véase art. 225 LSC que establece que los administradores deberán cumplir con sus deberes atendiendo a la naturaleza del cargo y atendiendo a las funciones atribuidas a cada uno de ellos.

499 En la relación de causalidad lo que se exige es que el daño sea la consecuencia del comportamiento ilícito del administrador remitiéndose a la doctrina general de la responsabilidad civil, véase DÍEZ PICAZO, L., Derecho de daños, Ed. Tecnos, Madrid, 1999, pp. 331 y ss. 
acreedores sociales del daño que causen por actos $u$ omisiones contrarios a la ley o los estatutos o por los realizados incumpliendo los deberes inherentes al desempeño del cargo, siempre y cuando haya intervenido dolo o culpa ${ }^{500}$. El cambio es relevante respecto a la legislación anterior que simplemente señalaba el nacimiento de la responsabilidad de los administradores por el daño que causen por actos sus omisiones contrarias a la ley o los estatutos o por los realizados incumpliendo los deberes inherentes al desempeño del cargo" ${ }^{\circ 01}$. En suma, se trataba de una responsabilidad que nacía de la actuación del administrador cuando causaba un daño.

En la actualidad, la LSC establece este régimen como un instrumento de control contra la actuación de los administradores, dibujando un modelo que cumpliría una doble función ${ }^{502}$. La primera, una función preventiva, pues advierte que si sus conductas fueran contrarias a la Ley, a los estatutos o a los deberes inherentes al cargo y causaran un daño o lesión serán sancionadas. La segunda, una función de resarcimiento, ya que los administradores deberán reparar el daño causado a la sociedad, a los socios y a los acreedores sociales. Se incluye además en esta Ley la mención de dos elementos intencionales que deben concurrir en la actuación de los administradores: el dolo o la culpa ${ }^{503}$, tal y como se venía considerando por nuestra doctrina jurisprudencial ${ }^{504}$. No obstante, en el régimen de la responsabilidad se constata la presunción de culpabilidad en los administradores cuando el acto es contrario a la Ley o los estatutos y, en cambio, los efectos de esta presunción no operarían en los actos contrarios a los deberes inherentes al cargo al añadirse que, "la culpa se presumirá salvo prueba en contrario, cuando el acto sea contrario a la ley o a los estatutos".

${ }^{500}$ Describiendo el planteamiento subjetivo de la responsabilidad de los administradores, véase MÁS-GUINDAL GARCÍA, J., "La responsabilidad de los administradores", en AA.VV., Gobierno Corporativo, cit., pp. 785-811.

${ }^{501}$ En este sentido, véanse; HERNANDO CEBRIÁ, L., "El deber de diligencia: artículo 225", cit., pp. 59-63; RODRÍGUEZ ARTIGAS, F., "El deber de diligencia", cit., pp. 421-423.

${ }^{502}$ Sobre la responsabilidad personal de los administradores derivada de su actuación MATEU DE ROS CEREZO, R., Práctica de gobierno corporativo. cit., pp. 86-87.

${ }^{503}$ Explicando la incidencia de los elementos intencionales de dolo o culpa en los presupuestos de la responsabilidad, véanse GRIMALDOS GARCÍA, M. I., "Presupuestos y extensión subjetiva de la responsabilidad. Solidaridad: artículos 236 y 237. Otras acciones por infracción del deber de lealtad", cit., pp. 339-343; QUIJANO GONZÁLEZ J., "Deber de lealtad, régimen de imperatividad y dispensa", en AA.VV., Estudios de la responsabilidad de los administradores, cit., pp. 21-49.

${ }^{504}$ Véanse SSTS de 4 de abril de 2003 (RJ 2772/2003); de 27 de octubre de 2006 (RJ 8930/2006). 
Por otro lado, en la LSC se incluye un régimen específico respecto al incumplimiento del deber de lealtad ${ }^{505}$, consistente en que los administradores tienen el deber de devolver el enriquecimiento injustamente obtenido, según indica el art. 227.2 LSC y, además, los socios pueden ejercitar contra los administradores la acción de responsabilidad en la defensa del interés social, sin necesidad de que la junta general acordara su ejercicio en el art. 239. 1 $\mathrm{LSC}^{506}$.

Así pues, la responsabilidad es de corte "subjetivo o por culpa", y contempla al administrador de hecho con las mismas condiciones que al nombrado por la sociedad. La exigencia de la responsabilidad, por consiguiente, conlleva el cumplimiento de una serie de requisitos. El primero, la realidad del daño sufrido; el segundo, la demostración de la conducta lesiva, salvo cuando opere la presunción de culpabilidad en los actos contrarios a la Ley o los estatutos; y, por último, la conexión causal entre el acto realizado y el daño producido a la sociedad a los socios o a terceros ${ }^{507}$. En definitiva, la presunción de culpabilidad opera en los administradores cuando el acto u omisión fuera realizado en contra de la Ley y los estatutos, tal y como establecía el ACPM; en cambio, se mantuvo intacto el art. 236.2 LSC que establecía que el acto lesivo autorizado o ratificado por la junta general no eximiría de responsabilidad a los administradores ${ }^{508}$.

De ahí que, para abordar la manera o el modo de exigir la responsabilidad del administrador de hecho debemos apuntar ${ }^{509}$ que tal exigencia dependerá, fundamentalmente, de cómo pudieron actuar aquellas personas que se dibujan en su definición, ya que el legislador quiso demostrar que se podrá exigir responsabilidad al administrador de hecho a

${ }^{505}$ Véase LLEBOT MAJO, J. O., "Los deberes y responsabilidad de los administradores”, cit., pp. 25-55.

${ }^{506}$ Explicando las incidencias de la reforma efectuadas por la Ley 31/2014 en nuestro sistema véase GRIMALDOS GARCÍA, M, I., "Presupuestos y extensión subjetiva de la responsabilidad", cit., pp. 329-339.

${ }^{507}$ En este sentido, véanse STSS de 26 de octubre de 2001 (RJ 2032/2001); de 25 de febrero de 2002 (RJ 1908/2002; de 4 de abril de 2003(RJ 2772/2003).

${ }^{508}$ Véanse GALACHO ABOLAFIO, A. F., "La Junta General y su competencia /obligación tras la reforma de la Ley de Sociedades de Capital", en AA.VV., Derecho de Sociedades, cit., pp. 749-775; JUSTE MENCÍA, J., "Presupuestos y extensión subjetiva de la responsabilidad", cit., pp. 444-487; SANJUAN Y MUÑOZ, E., "Competencia de la Junta de sociedades en los asuntos de gestión (competencias generales y adicionales)", en AA.VV., Estudios sobre órganos, cit., pp. 778-824.

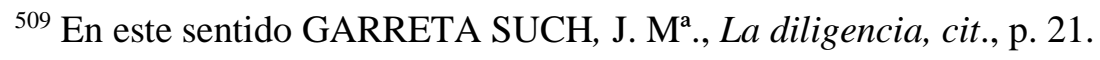


pesar de ser solo un hecho, con base en que los deberes no se definen por lo que son sino por a quién le son exigibles. En definitiva, que la responsabilidad resultará aplicable y exigible a todas las personas físicas o jurídicas que ejerzan funciones propias del cargo de administrador.

En definitiva, el punto de partida que nos puede proporcionar la base necesaria para exigir responsabilidad a todo ese conjunto de personas que engloba la definición de administrador de hecho se podría construir con base en el dato esencial de su forma de actuar en la sociedad, es decir, si ejercen las funciones de forma constante y continuada en el tiempo con un control efectivo en la sociedad ${ }^{510}$. No obstante, el administrador de hecho solo deberá resarcir el daño causado a la sociedad, a los socios o a terceros si en su actuación concurriera el nivel de exigencia para ser responsable ${ }^{511}$.

De manera que, si bien la responsabilidad contempla al administrador de hecho como administrador societario, también deberemos conocer los requisitos que nos permitirán exigirle el daño causado y, para ello, deberemos tomar como punto de partida los antecedentes que seguidamente pasamos a exponer. Primero, debemos encuadrar al administrador de hecho en los distintos regímenes de responsabilidad societaria bajo los que se encuentra sometido, entre ellos, el especial régimen de responsabilidad por obligaciones sociales; después, dilucidaremos en qué medida se pueden aplicar sus requisitos a cada una de las manifestaciones del administrador de hecho y, en particular al oculto, para concluir cuál será su nivel de exigencia por el incumplimiento de los deberes que determinan el nacimiento de las responsabilidades a las que se encuentran sometidos.

Y, por último, tendremos que solventar otra cuestión fundamental que consistirá en discernir cómo exigir responsabilidad al administrador de hecho conforme al proceso de diversificación que se ha establecido para la exigencia de la responsabilidad general de los administradores, ya que el cumplimiento de su deber de diligencia se construyó atendiendo a las funciones que hayan sido atribuidas a cada administrador en el art. 226 LSC, y teniendo en cuenta la naturaleza del cargo encomendado.

510 Ver por todos RODRÍGUEZ DE LAS HERAS BALLELL, T., "Requisitos para ser administrador", cit., pp. 735-736.

${ }^{511}$ Sobre los requisitos necesarios para ser administrador de hecho, véase MARTÍNEZ SANZ, F., "Los administradores responsables", cit., pp. 73-82. 


\subsection{Los requisitos de la responsabilidad general de los administradores en el} administrador de hecho

Los requisitos de la responsabilidad de los administradores, para que puedan ser aplicables al administrador de hecho, reciben actualmente un tratamiento unitario en el ámbito de las sociedades de capital, ya sean sociedades anónimas, abiertas o cerradas, cotizadas o no, o sociedades de responsabilidad limitada ${ }^{512}$. Esta aplicación obedece a la cláusula general establecida en el art. 226. 1 LSC, la cual implica que por el incumplimiento de "los deberes inherentes al desempeño del cargo" se deriva responsabilidad a los administradores societarios y a los administradores de hecho, siempre y cuando realicen actos que sean contrarios a la Ley, a los estatutos o al conjunto de deberes fiduciarios contemplados en los arts. 225 a 232 LSC $^{513}$. La razón de ser de la consideración anterior obedece a que en el art. 236 LSC no se menciona al administrador de hecho, y así las coordenadas de la responsabilidad general se trazan equiparando automáticamente al administrador de hecho con el administrador de derecho ${ }^{514}$. De ahí el conjunto de los requisitos de la responsabilidad de los administradores recogidos en la redacción del art. 236.1 LSC cuando dispone de forma general que ${ }^{515}$, "Los administradores responderán frente a la sociedad, frente a los socios y frente a los acreedores sociales del daño que causen por actos u omisiones contrarios a la ley o los estatutos o por los realizados incumpliendo los deberes inherentes al desempeño del cargo, siempre y cuando haya intervenido dolo o culpa". De esta forma, el administrador de hecho ha quedado encuadrado dentro de la categoría de administrador, pues en este artículo no se ha puntualizado diferencia alguna entre el administrador de derecho y el de hecho a efectos de responsabilidad.

El primer requisito que establece el art. 236 LSC se traduce, por una parte, en que el administrador de hecho debería de hacer lo indebido u omitir hacer lo debido y, además, el

512 Explicando el ámbito de aplicación de los presupuestos de la responsabilidad de los administradores, véase QUIJANO GONZÁLEZ, J., "Los presupuestos de la responsabilidad en el nuevo modelo del Consejo de administración (arts. 236.1 y 2 LSC)", cit., pp. 596-598.

${ }^{513}$ En este sentido, véase ALEJO GARMENDIA, B., Los deberes de diligencia y lealtad, cit., pp. 39-63.

${ }^{514}$ Para mayor estudio en relación a los presupuestos, véase LLEBOT MAJÓ, J. O., “Los deberes y responsabilidad de los administradores", cit., pp. 58-62.

515 Explicando las coordenadas de los presupuestos del nuevo régimen de la responsabilidad de los administradores MATEU DE ROS CEREZO, R., Práctica de gobierno corporativo, cit., pp. 85-88. 
acto u omisión tendría que resultar ilícito por ser contrario a la Ley, a los estatutos, o a los deberes inherentes a su cargo. Sin embargo, en el citado precepto solo se cita el incumplimiento de deberes legales en general, y esta generalidad obedece a que el incumplimiento de la Ley o de los estatutos no presenta problemática, pues basta que el administrador no realice las obligaciones que imponen los deberes legales para poder exigirle su responsabilidad; aunque para su incumplimiento por parte del administrador de hecho nos encontraríamos con la dificultad de su carencia en la designación formal. En cambio, en lo que respecta a los deberes inherentes al cargo, el administrador de hecho tendría que actuar en contra de la cláusula del deber general de administrar que es la diligencia debida, para cuyo cumplimiento no se vería impedido, aunque su ejercicio se vería más debilitado porque este deber se integra más bien con obligaciones de medios y el administrador de hecho carece de designación formal. Mientras que, para el cumplimiento de las obligaciones del deber de lealtad, como sus obligaciones se tratan más bien de resultados, el administrador de hecho podría cumplirlas $^{516}$.

El segundo requisito es que se haya causado un daño a la sociedad, a los socios o a los acreedores sociales con la sanción de reparar el daño ocasionado, el cual solo se podrá activar si se demuestra el daño producido al perjudicado. Para la valoración económica del daño se aplicarán las reglas del derecho común, es decir, que la persona que exija responsabilidad, ya sea un acreedor o un socio, tendrá que probar la culpa del administrador ${ }^{517}$. De ahí que la determinación de la indemnización solo se podrá conseguir cuando el daño haya sido valorado económicamente conforme a los parámetros del daño emergente y del lucro cesante, tal y como se contempla en la teoría de la responsabilidad civil por daños y perjuicios, es decir, cuando el daño haya sido valorado económicamente ${ }^{518}$.

En lo que atañe a cuál sería el daño que se podría imputar al administrador de hecho cuando este haya realizado una actuación ilícita en la sociedad bajo la apariencia de un título o en su manifestación oculta se considera que, si no concurre el nivel de diligencia exigible en

${ }^{516}$ En esta línea, explicando la responsabilidad de los administradores GRIMALDOS GARCÍA, Ma I., "Presupuestos y extensión subjetiva de la responsabilidad", cit., p. 339.

${ }^{517}$ Para la perspectiva de la valoración del daño en el derecho común, véase JUSTE MENCÍA, J., “Artículo 236. Presupuestos y extensión subjetiva de la responsabilidad”, cit., pp. 447-449.

518 Acerca del presupuesto del daño y la relación de causalidad para un estudio en profundidad, véase QUIJANO GONZÁLEZ, J., "La responsabilidad de los administradores", en AA.VV., Comentarios de la Ley de sociedades de capital, cit., pp. 1691-1698. 
el acto lesivo, no se podría activar la correspondiente acción de responsabilidad ${ }^{519}$. Y, con respecto al daño exigible a un administrador de hecho habría que determinar el daño en función de qué posibilidades tuvo ese administrador de hecho para cumplir con el deber qué fue causante del daño ${ }^{520}$.

El tercer requisito para que se desencadene la responsabilidad viene constituido por la concurrencia de dos elementos intencionales, el dolo o la culpa. Estos elementos se corresponden con el nivel de exigencia a los administradores cuando realicen actos ilícitos o contrarios a los deberes inherentes al cargo y perjudiquen a la sociedad, a los socios o a los acreedores sociales. La literalidad de que intervenga el dolo y la culpa en la actuación del administrador, conforme al art. 236 LSC, no ha constituido en verdad un cambio fundamental en el criterio para imputar responsabilidad, porque era un requisito expreso que venía recogido en el antiguo art. 79 LSA de 1951 cuando se decía que, los administradores responderían por "el daño causado por malicia, abuso de facultades o negligencia grave”. También la doctrina y la jurisprudencia ${ }^{521}$ no ponían en duda que la naturaleza de la responsabilidad no era estrictamente objetiva pues, se aceptaba un cierto agravamiento por los daños causados por el incumplimiento los deberes ${ }^{522}$. Y por este motivo, tradicionalmente la doctrina y jurisprudencia ${ }^{523}$ ya venían exigiendo elementos intencionales si el administrador realizaba una conducta contra la Ley o los estatutos. No obstante, parecía que estos dos elementos intencionales sólo podrían aplicarse en los deberes inherentes al cargo, dada la redacción del art. 133.1 LSA que implantaba una responsabilidad de corte objetivo contraria a

519 Conforme se consideraba por nuestra doctrina tradicional en este sentido, véase DÍAZ ECHEGARAY, J. L., Deberes y responsabilidad de los administradores, cit., p. 75-76; GARRETA SUCH, J. Ma , La diligencia y responsabilidad de los administradores. cit., p. 28.

520 Explicando la necesidad de la acción del administrador con eventual daño para resultar responsable, véase QUIJANO GONZÁLEZ, “Artículo 236. Presupuestos de la responsabilidad”, en AA.VV., Comentarios de la Ley de Sociedades de Capital, cit., pp. 1691-1707.

${ }^{521}$ En SSTS de 21 de mayo de 1992 (RJ 4274/1992); de 10 de marzo de 2003 (RJ 3755/2003).

${ }^{522}$ Sobre estas consideraciones QUIJANO GONZÁLEZ, J., "Los presupuestos de la responsabilidad de los administradores en el nuevo modelo del Consejo de ad ministración (arts. 236.1 y 2 LSC)", en AA.VV., Junta General, cit., p. 603.

${ }^{523}$ En tal sentido estableciendo la prueba de la culpa que corresponde al actuante perjudicado, véanse SSTS de 4 de abril de 2003 (RJ 1868/2003); de 19 de mayo de 2003 (RJ 5213/2003); de 22 de octubre de 2003 (RJ 74059/2003). 
aquel sistema de la responsabilidad que establecía la LSA de 1951, al exigir una responsabilidad subjetiva por malicia o por culpa en su art. $79^{524}$.

Otra cuestión que sigue siendo controvertida y objeto de debate doctrinal es la que versa sobre la responsabilidad especial regulada en el art. 367 LSC, que no es otra que la responsabilidad por las deudas de la sociedad cuando los administradores incumplan determinadas obligaciones legales calificadas como obligaciones de resultado ${ }^{525}$. Los presupuestos establecidos en este régimen son distintos a los exigidos para la responsabilidad general y, aunque, en este epígrafe no son objeto de estudio, sin embargo, para entender cómo se exigirá la responsabilidad a un administrador de hecho por su falta de nombramiento formal dada su importancia, adelantamos que los presupuestos especiales que ostenta esta singular responsabilidad no necesitarán de los elementos intencionales de dolo o culpa en la actuación de los administradores, pues serán sancionados aunque no concurran en su actuación por tratarse de obligaciones legales.

\subsection{La diligencia como medida de la culpa para exigir la responsabilidad y la} presunción de culpabilidad

Las siguientes líneas que vamos a exponer las dedicaremos a enfocar cómo se ha venido afrontando el funcionamiento de las normas que regulan la responsabilidad con los elementos intencionales de dolo y culpa, cuya naturaleza es de carácter subjetivo. Para el desarrollo de su estudio repasaremos cómo se incardinó la aplicación subjetiva de la responsabilidad al administrador de derecho, al de hecho y a otros cargos societarios que quedaron sujetos a la responsabilidad bajo los criterios de imputación establecidos en los apartados del art. 236.1 LSC ${ }^{526}$ : "Ios administradores responderán cuando haya intervenido dolo o culpa".

${ }^{524}$ Explicando esta evolución en los cambios de la responsabilidad ESTEBAN VELASCO. G., "La acción individual de responsabilidad", en AA.VV., La responsabilidad de los administradores, cit., pp. 189-298.

525 Para un mayor estudio, véase BELTRÁN SÁNCHEZ, E., "La responsabilidad de los administradores por obligaciones sociales", cit., pp. 326-346.

${ }^{526}$ Acerca del elemento de culpa como presupuesto necesario de la responsabilidad en los actos realizados por los administradores, véase JUSTE MENCÍA, J., “Art. 236. Presupuestos y extensión de la responsabilidad", cit., pp. 444-487. 
Así pues, el dolo y la culpa constituyeron, por fin, el presupuesto legal y necesario para poder iniciar la acción de responsabilidad contra los administradores. Esto es, los administradores además de realizar un acto antijurídico o ilícito tenían que haberlo realizado con dolo o culpa, aunque a la luz de la doctrina jurisprudencial ${ }^{527}$ el elemento intencional de culpa siempre había sido un requisito de imputabilidad subjetiva en actos contrarios a la Ley, y a los estatutos y a los deberes inherentes al cargo. La doctrina ${ }^{528}$ utilizaba los elementos intencionales del dolo o la culpa como criterios de imputación, analizando si hubo intención de querer realizar la conducta o si se realizó sin la diligencia debida por culpa ${ }^{529}$, es decir, se requerían dos juicos de valor. El primero, un juicio antijurídico que valoraba si la acción u omisión vulneraba de forma injustificada la Ley, los estatutos o un deber inherente al cargo de administrador. El segundo, determinar si concurrió la culpa, entendida como la falta de la diligencia debida.

De manera que, el régimen general de responsabilidad de los administradores se construyó como medida que servía de estímulo en la diligencia del administrador cumpliendo dos funciones. La primera, conseguir un criterio de conducta para el administrador y, la segunda, un parámetro objetivo que mediría la culpa, es decir, cuando el administrador vulneraba de forma injustificada la norma con voluntad surgiría el dolo; por el contrario, si vulneraba la norma infringiendo la diligencia debida aparecía la culpa ${ }^{530}$. De ahí, que la diligencia se consagró como el criterio de imputación de la responsabilidad, pues determinaba si el administrador sería responsable y si lo era se le exigiría responsabilidad porque había actuado sin la diligencia debida.

No obstante, como el deber de diligencia comprende obligaciones de contenido indeterminado, también llamadas obligaciones de medios, el nivel de diligencia exigible al administrador adquiriría un carácter subjetivo, pues se mediría en función de su grado de

527 Véanse SSTS de 27 de octubre de 2006 (RJ 8930/2006); de 4 de noviembre de 2010 (RJ $8868 / 2010)$.

${ }^{528}$ Con referencia a la explicación del requisito de la culpa en la actuación de los administradores, véase QUIJANO GONZÁLEZ, J., "Presupuestos de la responsabilidad”, cit., p. 603.

${ }^{529}$ La fórmula adoptada por el art. 133 LSA, véanse GRIMALDOS GARCÍA, Ma. I., "Presupuestos y extensión subjetiva de la responsabilidad", cit., pp. 340-441.

${ }^{530}$ Sobre la estimulación de la diligencia en el régimen de responsabilidad, SÁNCHEZ CALERO, F., Los administradores, cit., pp. 327. 
discernimiento o de si otro administrador actuaría de distinta forma en una situación y circunstancias similares ${ }^{531}$.

Al trasladar esta tesis al administrador de hecho para reclamarle responsabilidad se tendría que haber regulado un régimen jurídico específico y especial en función de sus posibilidades de actuación para cumplir los deberes de los administradores, y de esta forma se determinaría cuál sería el nivel de exigencia de su responsabilidad atendiendo a los medios que tuvo a su disposición para cumplir con los deberes, ya que por su falta de designación formal, y por ser solo un hecho, no tiene asignación de funciones ni de un cargo designado, quedando en una clara desventaja con respecto al administrador formal para asumir las consecuencias de la responsabilidad ${ }^{532}$. Es por ello que el legislador debería haber establecido distintos regímenes de responsabilidad atendiendo a la naturaleza del cargo atribuido a cada administrador y de las funciones asignadas ${ }^{533}$.

\subsection{La presunción de culpabilidad del administrador de hecho en los actos} realizados en contra de la Ley o los estatutos

La novedad más significativa para poder exigir la correspondiente atribución de responsabilidad es la presunción de la culpa en las actuaciones contrarias a la Ley o los estatutos, tal y como viene enunciada en el art. 236.1 LSC, "La culpa se presumirá, salvo prueba en contrario, cuando el acto sea contrario a la ley o los estatutos" ${ }^{534}$. De esta manera, la presunción de la culpabilidad supone la inversión de la carga probatoria ya que el administrador deberá demostrar que su conducta antijurídica fue realizada sin intención, o que el daño se produjo sin su culpa; en este sentido lo entendió la STS de 14 de marzo de 2007(RJ

531 Explicando la diligencia exigible como parámetro objetivo y subjetivo de la culpa, véase ESTEBAN VELASCO, G., "La acción individual de la responsabilidad”, cit., pp. 174 y 175.

${ }^{532}$ Ver por todos, GARCÍA DE ENTERRÍA, E., "La reforma de la ley de sociedades de capital en materia de gobierno corporativo", cit., pp. 78-79.

${ }^{533}$ En esta línea, MATEU DE ROS CEREZO, R., Practica de gobierno corporativo, cit., pp. 86-89.

${ }^{534}$ En este sentido, la STS de 14 de marzo de 2007 (RJ 1793/2007) en relación con una acción individual razona la sala que la desaparición de empresas sin haber practicado la oportuna liquidación comporta una vulneración de la Ley ya que vulnera un deber tan esencial que comporta la existencia de culpa, salvo prueba en contrario por parte de los administradores de que su actuar individual no fue negligente. 
1793/2007). En definitiva, el perjudicado solo tendrá que probar la ilicitud del acto y el daño causado $^{535}$.

Sin embargo, esta presunción de culpabilidad tiene un ámbito de aplicación muy restringido, pues no se aplicará cuando el acto fuera contrario a los deberes inherentes al cargo. Así, en la correspondiente acción de responsabilidad contra el administrador por actos contrarios a estos deberes se tendrá que probar que el acto fue realizado con dolo o por la culpa del administrador ${ }^{536}$. No obstante, la presunción de la culpabilidad sí que supuso un paso adelante, ya que antes suponía un esfuerzo por parte del perjudicado el tener que probar que la conducta antijurídica era contraria a la Ley o a los estatutos ${ }^{537}$.

Nosotros consideramos que la presunción de la culpabilidad debería de haberse aplicado también a los actos que sean contrarios a los deberes inherentes al cargo, ya que los perjudicados para poder exigir la responsabilidad a los administradores se verán obligados a tener que probar quién es el administrador autor de aquella actuación que dio lugar a un daño específico y, a su vez, probar su culpa cuando realizó aquel acto ${ }^{538}$. A este respecto, si bien sería fácil demostrar la ilicitud del acto en sede de deberes concretos, sin embargo, esta demostración no resultaría fácil respecto al deber de diligencia que, como es sabido, se materializa en conceptos jurídicos indeterminados ${ }^{539}$, y también en los deberes específicos del deber de diligencia como, por ejemplo, demostrar que el administrador no ostentaba información suficiente cuando realizaba el acto lesivo, o que no poseía la cualificación necesaria o la dedicación adecuada para la dirección en la sociedad cuando realizó el acto lesivo. Aunque, tal y como se redactó este artículo no se solucionaron los problemas que se

${ }^{535}$ En este sentido, CID BLASCO T., Y GARCÍA BIGUAZZI, T., "El régimen de responsabilidad de los administradores", cit., p. 77.

536 Véase SÁNHEZ CALERO, F., Los administradores, cit., pp. 133.

${ }^{537}$ En tal sentido, SSTS de 29 de diciembre de 2009 (RJ 406/2009) que expresaba esta dificultad de la demostración donde el tribunal no ha llegado a formarse un juicio de certeza, una vez que se ha constatado el vacío probatorio, y más recientemente de 20 de julio de 2010 (RJ 6563/2010) que establece las reglas de la carga de la prueba, como ha destacado también la STS de 4 de octubre de 2012 (RJ 759/2012).

${ }^{538} \mathrm{Al}$ respecto, GUERRERO TREVIJANO, M. C., El deber de diligencia de los administradores, cit., pp. 335 y ss.

539 Sobre los deberes especifico de diligencia LLEBOT MAJÓ, J. O., "Los deberes y responsabilidad de los administradores", cit., pp. 30-34. 
presentaban en la práctica para activar la responsabilidad, ya que los administradores son los únicos que disponen de medios para acreditar que actuaron diligentemente ${ }^{540}$.

Así pues, nuevamente, la aplicación de la presunción de culpabilidad planteó otra problemática, es decir, cómo demostrar que el administrador no se ajustó a los parámetros de un administrador diligente y cómo un tercero, ajeno a la sociedad, podría recabar las pruebas suficientes para demostrar los requisitos necesarios para activar el ejercicio de la responsabilidad. De manera sucinta pasaremos a exponer algunas soluciones: Primera, la persona que quiera activar la exigencia de la responsabilidad deberá demostrar cuál fue el grado de información necesaria que tenía el administrador cuando realizó aquel acto lesivo y, segunda, demostrar que el administrador es culpable comparando su comportamiento con otra actuación adecuada realizada por otro administrador que actuaría de otra forma muy distinta en las mismas condiciones y circunstancias.

Al trasladar estas consideraciones a nuestro objeto de estudio, el administrador de hecho, consideramos que la presunción de culpabilidad debería de aplicase también a los actos contrarios a los deberes inherentes al desempeño del cargo ${ }^{541}$. No obstante, también entendemos, siguiendo la literalidad del precepto que, "La culpa se presumirá, salvo prueba en contrario, cuando el acto sea contrario a la ley o los estatutos" y que, en todo caso, sería el demandante el que tendría que demostrar la culpabilidad a través de los medios establecidos el art. 217 LEC cuando se reclama responsabilidad al administrador de hecho, pues primero se tendría que demostrar que quién realizo aquel acto lesivo causante del daño era una persona que merecería ser calificado como tal ${ }^{542}$.

${ }^{540}$ En esta línea. la doctrina se pronuncia diciendo que la carga de la prueba se justifica por la aplicación de nuestros tribunales de la doctrina del juicio empresarial que no cuestionan las decisiones de los administradores a menos que se hay demostrado la falta de prudencia en la toma de decisiones, véase GUERRERO TREVIJANO., M. C., El deber de diligencia, cit., pp. 337 y ss.

${ }^{541}$ En este sentido, explicando estas consideraciones sobre el presupuesto de la culpa JUSTE MENCÍA, J., "Artículo 236. Presupuestos y extensión subjetiva de la responsabilidad", cit., p. 448. Y sobre la exoneración de los administradores, véase QUIJANO GONZÁLEZ J., “Articulo 236”, cit., p. 1703.

${ }^{542}$ En este sentido, véase JUSTE MENCÍA, J., “Artículo 236. Presupuestos y extensión subjetiva de la responsabilidad", cit., p. 449. 


\section{LA PROBLEMÁTICA DE LA RESPONSABILIDAD SOLIDARIA EN EL ADMINISTRADOR DE HECHO}

\section{En general}

Establecido tradicionalmente por nuestro sistema el carácter solidario de la responsabilidad, se ha aplicado sobre el modelo de organización de gestión integrada o monista $^{543}$, en el que los miembros del órgano de administración participan en la toma de las decisiones de forma uniforme quedando las voluntades unificadas a los efectos de exigir la responsabilidad solidaria de los administradores dispuesta por el art. 237 LSC. En concreto, recordemos que este precepto señala que, “Todos los miembros del órgano de administración que hubieran adoptado el acuerdo o hubieran realizado el acto lesivo responderán solidariamente", es decir, la responsabilidad por su carácter solidario se proyectará de forma homogénea y con la misma intensidad sobre todo el conjunto de los miembros que integran el órgano de administración de la sociedad ${ }^{544}$.

El fundamento de la responsabilidad solidaria estriba en la asunción de deudas ajenas que se podría catalogar de fianza ex lege de acuerdo con el art. $1823 \mathrm{CC}$, pues lo que se pretende es que los acreedores ostenten el ius eligendi y variandi que viene regulado en el art.1144 CC, el cual consiste en que una vez que se ha realizado el pago por uno de los administradores se ejercitaría posteriormente la acción de regreso contra los demás, tal y como dispone el art. 1145 CC. Por ello, se diseñó la ampliación de su ámbito subjetivo a la definición legal del concepto de administrador de hecho en el art. 236. 3 LSC, con la finalidad de que respondieran todas las personas que alcanzaran esta consideración solidariamente con el administrador de derecho.

El problema reside en la excepción contemplada por el art. 237 LSC, "Salvo los que prueben que, no habiendo intervenido en su adopción y ejecución, desconocían su existencia o, conociéndola, hicieron todo lo conveniente para evitar el daño o, al menos, se opusieron

\footnotetext{
${ }^{543}$ Haciendo estos comentarios, véase ALONSO UREBA, A., "Mejoras en la estructura y calidad de las decisiones del Consejo", cit., pp. 25-26.

${ }^{544}$ Para mayor estudio sobre la configuración del órgano de administración sobre el sistema monista y el dualista, véase MILANS DEL BOSCH PORTOLES, I. Y UNCETA LABORDA, M., "La configuración y la estructura de los órganos de gobierno de las corporaciones", en AA.VV., Gobierno corporativo, cit., pp. 163-201.
} 
expresamente a aquel", porque el administrador de hecho se ha caracterizado por no estar formalmente integrado dentro del órgano de administración y, por esta razón, se encontraría limitado para que operaran las excepciones previstas en el art. 237 LSC, que son bastante limitadas. En concreto, en un órgano de administración colegiado no podría alegar que se opuso expresamente a la adopción del acuerdo lesivo ${ }^{545}$. Así que el problema radica en el modelo organizativo que históricamente se hallaba asentado en la colegialidad, con una responsabilidad solidaria que implicaba que los integrantes del órgano de administración respondían de igual forma a pesar de que no hubiesen realizado el acto lesivo y no tuviesen atribuidas las mismas funciones, o que sus miembros detentasen atribuciones de distinta naturaleza ${ }^{546}$.

A estos efectos, consideramos que no se puede exigir la responsabilidad a todos los administradores por igual y sobre todo al administrador de hecho, pues con la presunción establecida en el art. 237 LSC se responsabiliza a todos los administradores como si hubieran participado en la comisión u omisión de actos ilícitos realizados por otros. Con arreglo a ello determinaremos los motivos en los que basamos esta afirmación:

Primero, los actos realizados por los delegados que forman parte de las comisiones ejecutivas porque son los delegados los que han adoptado el acto objeto de reclamación y, en este caso, la responsabilidad solidaria solo operaría en un plano horizontal cuando los administradores actúan con funciones homogéneas.

Segundo, los administradores actúan con funciones diferentes en un plano vertical ${ }^{547}$, y si se dejara a un lado la forma colegiada el administrador respondería de una forma individualizada según el cargo atribuido y funciones encomendadas ${ }^{548}$.

${ }^{545}$ En torno a esta consideración EMBID IRUJO, J, M., "La responsabilidad de los administradores de la sociedad anónima tras la Ley de transparencia", cit., pp. 2409-2410.

546 Explicando que no se puede exigir responsabilidad a los administradores cuando tienen atribuidas distintas funciones, véase ESTEBAN VELASCO, G., "El gobierno de las grandes empresas (reforma legal versus códigos de conducta)", cit., pp. 95-209 y pp. 168-177.

${ }^{547}$ Descartando la igualdad de la responsabilidad solidaria en un plano vertical, véase QUIJANO GONZÁLEZ, J., "Responsabilidad de consejeros y directivos. La evaluación de la dirección por el consejo de administración" cit., pp. 97-98.

548 En este sentido, véase MATEU DE ROS CEREZO, R., Práctica de gobierno corporativo, cit. p. 88. 
Tercero, antes de extender la responsabilidad se debería identificarse quién actuó y las circunstancias del momento de la decisión, y sólo entonces se podría considerar culpable al resto por el resultado lesivo realizado por otro administrador ${ }^{549}$. Esta postura se ratifica por la STS de 26 de mayo de 1998 (RJ 4004/1998) en el caso concreto de una sociedad que se encontraba integrada solo por dos socios, en referencia al supuesto de un resultado final de pérdidas; en ella se intenta responsabilizar al socio administrador por el incumplimiento del deber de convocar la junta, cuando en realidad el otro socio tampoco cumplió con esta obligación, pues si no fuera así sería una situación de abuso del derecho societario ${ }^{550}$.

Por tanto, la responsabilidad solidaria perderá su sentido y no debería aplicarse si se identificó quién realizo el acto, salvo que resultara difícil individualizarse con base en el reparto de las funciones atribuidas a los distintos administradores. En este sentido, la jurisprudencia, en la STS de 23 de febrero 2010 (RJ 1293/2010), ya consolidó la postura de que sólo debería aplicarse a todos los administradores si no existiera posibilidad de determinar el grado de participación de cada administrador en el daño causado ${ }^{551}$.

Por otro lado, los administradores no deberían quedar fuera de la responsabilidad solidaria solo si prueban que no intervinieron en el resultado conforme a las reglas que se establecen en el art. 237 LS, "que no han intervenido en su adopción y ejecución, desconocían su existencia o, conociéndola, hicieron todo lo conveniente para evitar el daño o, al menos, se opusieron expresamente a aquel". En concreto, consideramos que con una reforma del modelo organizativo monista adaptándolo al modelo dualista con dos órganos que tengan un estatuto jurídico diferente sería suficiente, ya que uno de ellos dirigiría y el otro supervisaría la actuación realizada. Así, sería lógica la responsabilidad atribuida y se realizarían mejor las funciones de supervisión, pues se determinaría quién responde de los

${ }^{549}$ En esta materia, RODRÍGUEZ DE LAS HERAS BALLELL, T., "Requisitos para ser administrador y extensión subjetiva de la responsabilidad", cit., p. 761.

${ }^{550}$ En idéntico sentido se pronunció nuestra jurisprudencia mayor en la STS de 26 de mayo de 1998 (RJ 4004/1998) "cuando dos socios forman una sociedad de responsabilidad limitada, y entre ellos, surge una litis, en la cual se discute quién es el administrador de la sociedad. De la prueba practicada, singularmente de las facturas reclamadas, tarjetas incorporadas, documentación, se infiere que nos hallamos ante una sociedad entre dos personas, cuyas decisiones eran tomadas por una y otra persona, pero bajo la cobertura formal de administrador único".

${ }^{551}$ En torno a estas consideraciones STS de 23 de febrero 2010 (RJ 1293/2010). 
actos y quién es el administrador culpable ${ }^{552}$; de esta forma la responsabilidad solidaria solo se exigiría cuando se sumara al fallo de supervisión la falta de la diligencia en la dirección ${ }^{553}$.

\section{2. la responsabilidad solidaria entre el administrador de hecho y el administrador de derecho}

El ámbito subjetivo de la responsabilidad que viene prevista en el art. 237 LSC simplemente hace referencia a los miembros que integran el órgano de administración sin tener en cuenta que el administrador de hecho se caracteriza por no estar integrado formalmente en dicho órgano de administración. Por este motivo, para aplicar la regla de la responsabilidad solidaria al administrador de hecho distinguiremos dos cuestiones que son fundamentales. La primera, si esta regla se debería aplicar al administrador de hecho por los actos realizados por los administradores de derecho y, la segunda a la inversa, si esta regla se debería aplicar al administrador de derecho por el daño ocasionado por el de hecho.

Debemos partir de la premisa de que la responsabilidad debe dirigirse frente a los administradores de derecho en base a que son los responsables directos de los daños ocasionados por el desempeño del cargo dada su designación formal, aunque el daño se haya realizado por un administrador de hecho. El criterio consolidado es que tanto el administrador de derecho como el de hecho son responsables de los errores o irregularidades producidas por las actuaciones de ambos con base en la perversión que entrañaría utilizar la actuación de los administradores de hecho con unos fines ajenos al sistema societario ${ }^{554}$.

${ }^{552}$ Explicando el riesgo de la colegiación y los miembros con distintas funciones a la hora de exigir la responsabilidad, véase PERDÍCES HUETOS, A. B., "Los riesgos de la colegiación como principio legal de funcionamiento y estructuración del consejo de administración", en AA.VV., Cuaderno de Derecho para Ingenieros, cit., pp. 49-62 y pp. 54-55.

${ }^{553}$ Los partidarios de la corriente que consideran que el sistema dualista sería el mejor modelo para poder exigir la responsabilidad solidaria, véanse ALONSO UREBA, A., "Liderazgo en el consejo vs liderazgo en la dirección (la interactividad entre la supervisión y la dirección efectiva)", cit., p. 25; RODRÍGUEZ ARTIGAS, F., "Comentarios a las recomendaciones del Código Unificado de Buen Gobierno", RdS, 2007.

${ }^{554}$ En esta materia y consolidando la responsabilidad del administrador de hecho y el administrador de derecho, véase DÍAZ ECHEGARAY, J. L. El administrador de hecho, cit., pp. 187-190. También, a estos efectos JUSTE MENCÍA, J., "En torno a la aplicación del régimen de responsabilidad", cit., 446. 
La jurisprudencia, en SSTS de 14 de marzo (RJ 1973/2007) y de 8 de febrero 2008 (RJ 2664/2008), que confirman las sentencias de 7 de junio 1999 (RJ, 4730/1999) y de 22 de marzo de 2004 (RJ 1661/ 2004), también considera aplicable la solidaridad en la responsabilidad tanto al administrador de derecho como al de hecho, cuando la doble condición operara en la misma persona. Así, podrá ocurrir que en una misma persona coincidiera la calificación de administrador de hecho en un tiempo determinado y, posteriormente, la calificación jurídica de administrador de derecho. En esta misma línea la coexistencia de la responsabilidad entre el administrador formal y el de hecho concurriría en el ejemplo paradigmático de un administrador de derecho que solo tenía por objeto eludir la responsabilidad de quien asumía todo control y la gestión de la sociedad bajo la cobertura de un simple apoderamiento ${ }^{555}$. Aunque, por otro lado, en sentido contrario, el administrador de derecho sería el auténtico responsable de la buena marcha de la sociedad, máxime si trata de la responsabilidad por la omisión de las obligaciones legales, $v$. g., de la presentación de cuentas anuales donde el administrador de hecho no se encuentra obligado legalmente ${ }^{556}$.

Por consiguiente, el administrador de derecho en base al deber de diligencia no queda exento de responsabilidad en el caso concreto de la actuación de un apoderado calificado como administrador de hecho ya que, por su carácter de subordinado en todo caso, el que respondería sería el administrador de derecho por la culpa "in eligendo" o culpa "in vigilando", aunque el administrador de hecho haya decidido las principales decisiones de gestión por las amplias facultades que ostentaba ${ }^{557}$.

Otro ejemplo lo encontramos con el administrador cesado, que deberá responder si el administrador de hecho aparece por no haberse dado cumplimiento al deber de inscribir su nombramiento en el Registro Mercantil, o si tal nombramiento no se canceló a pesar de que se encontraba caducado, o también cuando el administrador de derecho aceptaba la influencia del administrador de hecho oculto. Así que, admitir la tesis general de que el administrador de

${ }^{555}$ En este sentido, SSTS de 14 de marzo (RJ 1973/2007); de 8 de febrero 2008 (RJ 2664/2008) que confirman las sentencias de 7 de junio 1999 (RJ, 4730/1999); de 22 de marzo de 2004 (RJ 1661/ 2004).

${ }^{556}$ Para un análisis detallado sobre la contabilidad y la presentación de las cuentas anuales por los administradores de hecho y de derecho, véase GARRETA SUCH, J., M ${ }^{\mathrm{a}}$., La diligencia, cit., pp. 95105.

557 Explicando estas consideraciones, véanse ALONSO UREBA, A., "Presupuestos de la responsabilidad social de los administradores de una SA", cit., pp. 639 y ss.; JUSTE MENCÍA, J., "En torno a la aplicación", cit., pp. 446; POLO SÁNCHEZ, E., Los administradores, cit., pp. 290 y ss. 
derecho no deberá responder por los actos realizados por el de hecho conllevaría vaciar de contenido las normas de responsabilidad de los administradores ${ }^{558}$.

No obstante, el administrador de derecho no responderá por los actos cometidos por el de hecho si demuestra que él no causo daño aunque, por otro lado, en el art. 237 LSC se establece una presunción de la culpabilidad en los administradores, si bien esta presunción no se traduce en que el administrador de derecho tenga que asumir la responsabilidad del de hecho cuando este viene realizando las competencias legales que corresponden a los administradores formales designados por la sociedad, y al margen de que tengan el deber de cumplir con los deberes legales de los administradores.

Por tanto, el administrador de hecho para que no respondiera solidariamente con el de derecho tendría que haber hecho todo lo posible para que, en ningún caso, se hubiese producido el daño a través de cualquier medio, como utilizar a un socio para convocar la junta para que se adoptase el acuerdo de la disolución; es decir, debe demostrar que hizo todo lo necesario para cumplir con el mandato legal ${ }^{559}$. De ahí que la extensión de la regla de la responsabilidad solidaria al administrador de hecho sea necesaria en virtud del art. 236.3 LSC, al hacerse extensiva a aquellas personas que se integran en la definición del administrador de hecho y, por ello, quedan sujetos a la declaración general de la responsabilidad.

Así que, la cuestión de si la actuación del administrador de hecho en la sociedad implicaría la exclusión de la responsabilidad del administrador formal la respuesta es clara: no quedará excluido de responsabilidad por la actuación de los administradores de hecho por estar obligado a tener que cumplir con los deberes de diligencia y el deber de lealtad ${ }^{560}$.

${ }^{558}$ Véase DÍAZ ECHEGARAY, J. L. El administrador de hecho, cit., pp. 188.

${ }^{559}$ Aplicando la regla de la responsabilidad solidaria a la figura de los administradores de hecho y al administrador de derecho, véase QUIJANO GONZÁLEZ, J., "La responsabilidad de los administradores por no disolución de la sociedad y las causas de exoneración”, cit., p. 83; EMBID IRUJO, J. M., "La responsabilidad de los administradores de la Sociedad Anónima tras la Ley de Transparencia", cit., pp. 2379-2413.

${ }^{560}$ Véase DÍAZ RUÍZ, E., "La coordinación de los administradores solidarios de las sociedades de capital como manifestación del deber de diligencia", cit., pp. 1003-1014. 


\section{EL RÉGIMEN ESPECIAL DE RESPONSABILIDAD POR OBLIGACIONES SOCIALES EN EL ADMINISTRADOR DE HECHO}

\section{Evolución del ámbito objetivo y subjetivo}

Debe abordarse, con independencia de la responsabilidad del administrador de hecho, la responsabilidad por obligaciones sociales. Esta responsabilidad fue introducida por la Ley 19/1989, de 25 de julio de 1989, en el derogado art. 262.5 TRLSA, donde no se mencionaba al administrador de hecho expresamente; omisión que se ha mantenido en LSC incluso tras las reformas operadas por la Ley $31 / 2014^{561}$. La creación de esta especial responsabilidad supuso su separación del régimen general de responsabilidad debido a su naturaleza objetiva, la cual se activaría si los administradores incumplieran con los presupuestos previstos en el art. 262.5 TRLSA y en el art. 105.5 LSRL. En concreto, estos presupuestos comprendían la omisión de la convocatoria de la junta general para adoptar el acuerdo de disolución en el plazo de dos meses desde concurrieran algunas de las causas de disolución de la sociedad previstas en los referidos artículos; es decir, a los administradores se les sancionaba con la obligación de responder personalmente junto con la sociedad por el conjunto de las deudas de la sociedad ${ }^{562}$.

Posteriormente, este régimen especial de la responsabilidad de los administradores fue alterado por la Ley Concursal, ya que se introdujo una alternativa muy significativa en la causa de disolución por pérdidas muy graves en el art. 260.4 TRLSA. Así, los administradores deberían solicitar el concurso de la sociedad si fuera procedente y, por ende, los administradores tenían como cumplimiento alternativo solicitar la disolución o el concurso en el art. 262.5 TRLSA ${ }^{563}$. La redacción del artículo fue controvertida, pues un sector doctrinal sostenía que la responsabilidad solo debería afectar a las deudas originadas después del nacimiento de la causa de disolución. En cambio, otro sector afirmaba que debería alcanzar

561 Explicando la modificación legislativa de las pérdidas por la adaptación a la CEE, véase BELTRÁN SÁNCHEZ, E., "La responsabilidad de los administradores por obligaciones sociales", cit., pp. 301-352.

562 Acerca del ámbito objetivo de esta especial responsabilidad de los administradores, para su mayor estudio, véase RODRÍGUEZ RUÍZ VILLA, D. Y HUERTAS VIESCA, M ${ }^{\mathrm{a}}$. I., Responsabilidades, cit., pp. 212-243.

${ }^{563}$ Sobre el sistema legal de la evolución de la responsabilidad de los administradores, véase BELTRÁN SÁNCHEZ; E., "La responsabilidad de los administradores por las deudas sociales", cit., pp. 249-255. 
solo a las deudas anteriores, siempre que fueran vencidas y exigibles después de la causa de disolución ${ }^{564}$.

Unos años más tarde, el alcance de esta responsabilidad se clarificó expresamente por la reforma de la Ley 19/2005, de 14 de noviembre, que introdujo en el art. 265.2 LSA $^{565}$, que decía, "Las obligaciones sociales reclamadas se presumirán de fecha posterior al acaecimiento de la cusa legal de disolución de la sociedad, salvo que los administradores acrediten que son de fecha anterior". A partir de este hito legislativo, los administradores solo responderían de las deudas sociales posteriores a la causa de disolución, sin mencionar expresamente al administrador de hecho.

Posteriormente, el art. 367 LSC reprodujo el mismo texto del art. 265.2 LSA determinando claramente el criterio temporal para exigir la responsabilidad por las deudas de la sociedad. No obstante, se olvidaron dos aspectos muy significativos, entre ellos y con relación a nuestro objeto de estudio, resaltamos los siguientes: El primero, que no se mencionaba al administrador de hecho como sujeto responsable en esta especial responsabilidad, surgiendo la duda de cómo se le debería aplicar esta responsabilidad que, por ser un hecho, no se encontraba legitimado formalmente para desarrollar los deberes prescritos en el art. 367 LSC. El segundo, que la Ley no mencionaba la naturaleza de las deudas sociales cuando los administradores no habían promovido en el plazo de dos meses la junta para acordar el acuerdo de disolución de la sociedad o no solicitaron el concurso de la sociedad ${ }^{566}$; en este sentido, destacamos la jurisprudencia formulada en las SSAP de Toledo de 1 de junio de 1995 (RJ 1861/1995), de Barcelona de 19 de abril de 1995 (RJ 987/1995), y de Murcia de 19 de julio de 2003 (RJ 235129/2003), así como la STS de 16 de diciembre de 2004 (RJ

${ }^{564}$ Para el primer argumento, véanse BELTRÁN SÁNCHEZ, E., "La modificación legal del ámbito objetivo del ámbito objetivo de responsabilidad de los administradores por las obligaciones sociales", $A D C$, 2006, p. 253; VIÑUELAS SANZ, M., "La modificación del ámbito objetivo de la responsabilidad de los administradores por las deudas sociales", RDM, núm. 266, 2007, pp. 995-1036. Sostiene posición distinta, VICENT CHULIÁ, F., "La responsabilidad de los administradores en el concurso", $R D C$, núm. 4, 2006, pp. 15 y ss.

565 Véase Disposición final primera de la Ley 19/2005, de 14 de noviembre, sobre la sociedad anónima europea domiciliada en España, que entró en vigor el 14 de noviembre de 2005, BOE de 15 de noviembre.

566 Al respecto, MARTÍN REYES, M. A., "La insolvencia de las sociedades de capital y la exigencia de responsabilidad a sus administradores", $R D M$, núm. 277, 2010, pp. 835-898. 
825/2004), donde se consideraba que alcanzarían a todas las deudas de negocio y a las obligaciones que se devenguen por Ley, es decir, a todo el pasivo social ${ }^{567}$.

A estos efectos entendemos, con respecto al administrador de hecho, que se tendría que tener en cuenta en qué medida contribuyó a su incumplimiento su falta de designación formal $^{568}$. De ahí, que el fundamento de esta responsabilidad encuentra su apoyo en las garantías que se ofrecen a los acreedores, ya que la Ley permite que se añada al patrimonio de la sociedad el propio patrimonio personal de los administradores ${ }^{569}$, pues no se fundamentó en los daños acaecidos por no disolver o no solicitar el concurso sino que más bien reposa en la sanción de tener que resarcir a los acreedores por las deudas de la sociedad ${ }^{570}$ cuando resulten pérdidas que puedan desencadenar a una situación de crisis económica. En este sentido lo expresan las SSTS de 15 de julio de 1997 (RJ 5609/1997); de 21 de septiembre de 1999 (RJ 7230/1999); de 20 de julio de 2001 (RJ 6865/2001); de 14 de noviembre de 2002 (RJ 9762/2002) y de 28 de abril de 2006 (RJ 3287/2006) ${ }^{571}$. El fundamento principal de esta responsabilidad es la tutela de los acreedores sociales, ya que agrava la responsabilidad de los administradores, pues bajo la amenaza de que resulten responsables por las deudas sociales cumplirían con las obligaciones legales.

${ }^{567}$ En este sentido, véanse SSAP de Toledo de 1 de junio de 1995 (RJ 1861/1995); de Barcelona de 19 de abril de 1995 (RJ 987/1995); de Murcia de 19 de julio de 2003 (RJ 235129/ 2003), y STS de 16 de diciembre de 2004 (RJ 825/2004).

568 Mostrando la heterogénea procedencia de las deudas sociales, véase VALENZUELA GARACH., J., La responsabilidad de los administradores en la disolución y el concurso de las sociedades capitalistas, Ed. Marcial Pons, Madrid-Barcelona 2007.

${ }^{569}$ Explicando el carácter sancionador de esta responsabilidad, véanse, BELTRÁN SÁNCHEZ, E., "La responsabilidad de los administradores por obligaciones sociales", cit., pp. 331-341. Sobre la explosión de demandas sobre esta responsabilidad BERCOVITZ RODRÍGUEZ-CANO, A., "Régimen general de la responsabilidad civil de los administradores de las sociedades de capital", en AA.VV., La responsabilidad de los administradores, cit., pp. 15-25.

570 La jurisprudencia del TS, en un principio, se inclinó por exigir responsabilidad a los administradores que habían perjudicado a los acreedores en este sentido STS de 15 de julio de 1997 (RJ 5609/1997), después ha modificado su postura y en las numerosas sentencias de los últimos años ha declarado sin que quepa duda alguna al respecto, que la citada responsabilidad constituye una modalidad ex lege que requiere tan sólo la prueba de los hechos que son presupuestos de la sanción, véanse SSTS de 21 de septiembre de 1999 (RJ 7230/1999); de 20 de julio de 2001 (RJ 6865/2001); de 14 de noviembre de 2002 (RJ 9762/2002) y de 28 de abril de 2006 (RJ 3287/2006).

571 Sobre la responsabilidad por no solicitar el concurso de la sociedad, véase GONZÁLEZ CABRERA, I., "Primeras reflexiones sobre la responsabilidad", $R d S$, núm. 41, 2013, pp. 364 y ss. 
Por consiguiente, las funciones principales de la responsabilidad por obligaciones sociales son dos. La primera, una función preventiva para que los administradores cumplan con la obligación de disolver la sociedad por alguna de las causas previstas en el art. 363 LSC, pues en caso de incumplimiento responderán personalmente con sus propios bienes presentes y futuros, tal y como se dispone en el art. 1911 CC. La segunda, una función para concursal, que es evitar la futura y definitiva insolvencia de la sociedad.

\section{Presupuestos de la responsabilidad por obligaciones sociales}

Esta especial responsabilidad por obligaciones sociales se sigue regulando del mismo modo que en el art. 367 LSC, antes de la reforma de la Ley 31/2014. Así, el art. 367 LSC establece que, "Responderán solidariamente de las obligaciones sociales posteriores al acaecimiento de la causa legal de disolución los administradores que incumplan la obligación de convocar en el plazo de dos meses la junta general para que adopte, en su caso, el acuerdo de disolución, así como los administradores que no soliciten la disolución judicial o, si procediere, el concurso de la sociedad”. El nacimiento de esta responsabilidad requiere, por tanto, la concurrencia de los siguientes presupuestos. El primero, la existencia de las causas de disolución previstas en el art. 363.1.LSC ${ }^{572}$, es decir, la disolución de la sociedad por el cese del ejercicio de la actividad, por la conclusión del objeto social, por la imposibilidad manifiesta de conseguir el fin social, por la paralización de los órganos y por pérdidas cualificadas en la sociedad. El segundo, la pasividad del administrador que no procedió a la convocatoria de la junta general para promover la disolución de la sociedad, la solicitud de la disolución judicial o, cuando procediese, el concurso de la sociedad. A los dos anteriores presupuestos hay que sumarle un tercero, el límite temporal de dos meses desde que se originaran las causas de disolución, es decir, que dentro de ese plazo se deberá solicitar a la junta que acuerde la disolución de la sociedad, además de la inexistencia de una causa que justifique la omisión de estos deberes legales ${ }^{573}$.

${ }^{572}$ Sobre la legitimación para poder ejercitar la acción prevista en el art. 376 LSC, véase BELTRÁN SÁNCHEZ, E., "Perdidas y responsabilidad de los administradores. (Comentarios a las Sentencias de la Audiencia Provincial de Zaragoza de 23 de noviembre de 1991, y de la Audiencia Provincial de Oviedo de 1 de diciembre de 1992)", $R d S$, julio- septiembre 1992, pp. 471-486.

573 Véanse ALCOVER GARAU, G., "La responsabilidad de los administradores de la sociedad anónima por las deudas sociales ex art. 262.5 y los procedimientos concúrsales", $R d S$, núm. 8, 1997, pp. 265 y ss.; MARÍN DE LA BÁRCENA GARCÍA, M., "Responsabilidad de los administradores de sociedades de capital por no promoción de la disolución o el concurso (sobre retroactividad de la 
Aunque la Ley no menciona más requisitos para que nazca esta responsabilidad en el art. 367 LSC, hay que añadirle otros. Primero, la existencia de deudas en la sociedad no satisfechas a los acreedores de la sociedad, ya que esta acción se reserva a los acreedores sociales cuando sus créditos no han sido satisfechos por la insolvencia de la sociedad ${ }^{574}$. Segundo, la inexistencia de causa manifiesta que justifique la omisión legal; en este sentido SSTS de 29 de julio de 2008 (RJ 4634/2008); de11 de diciembre de 2008 (RJ 5910/008) ${ }^{575}$. Tercero, que el administrador actuara sin buena fe; en este sentido SSTS de 4 de febrero de 2009 (RJ 1364/2009); de 27 de septiembre de 2010 (RJ 7140/2010); de 17 de marzo de 2011(RJ 2880/ 2011); de 19 de mayo de 2011 (RJ 3980/ 20011); de 13 de marzo de 2012 (RJ $4885 / 2012)^{576}$. De ahí, que si el administrador acreditara una causa que justificara tal omisión se podría exonerar por falta de culpa, tal y como se dispone en el art. 213 LSC, es decir, si el administrador intentó e hizo todo lo necesario para que se adoptara el acuerdo de disolución ${ }^{577}$. No obstante, el elemento intencional de culpa queda excluido de esta responsabilidad, pues basta el incumplimiento de los presupuestos que establece el art. 367 LSC, desde que acaeció la causa de disolución ${ }^{578}$, para activar la acción por el simple

reforma de los arts. 265.5 LSA y 105.5 LSRL”, $R d S$, núm. 26, 2006, pp. 455 y ss.; MOYA JIMÉNEZ, A., La responsabilidad de los administradores de empresas insolventes, Ed. Bosch, Barcelona, 2009, pp. 288 y ss.; PABLO-ROMERO GIL-DELGADO, Mª. C., "Responsabilidad de los administradores de sociedades por no haber instado el concurso ¿supuesto asegurable?", en $R d S$, núm. 26, 2006, pp. 311 y ss.; ROJO FERNÁNDEZ- RÍO, A., "Los deberes legales de los administradores en orden a la disolución de las sociedades de capital como consecuencia de pérdidas", Derecho de Sociedades, Libro homenaje a Fernando Sánchez Calero, v. II, Ed. McGraw Hill, Madrid, 2002, pp. 1437 y ss.; SÁNCHEZ CALERO, F., "Administradores", en AA.VV., Comentarios a la Ley de Sociedades Anónimas, cit., pp. 240 y ss.

${ }^{574}$ En este sentido, véanse SSTS de 29 de julio de 2008 (RJ 4634/2008); de11 de diciembre de 2008 (RJ 5910/008).

${ }^{575}$ En este sentido, véanse SSTS que establecen una responsabilidad objetiva de la responsabilidad por de 20 de diciembre de 2000 (RJ 10130/2000); de 20 de abril de 2001 (RJ 8134/2001); de 25 de abril de 2002 (RJ 459/2002); de 30 de abril de 2008 (RJ 3531/2008); de 20 de noviembre de 2008 (RJ 6059/2008), de 13 de abril de 2012 (RJ 5901/2012).

${ }^{576}$ En esta línea SSTS que admiten que a pesar de haber concurrido los presupuestos objetivos de la responsabilidad los administradores quedan exonerados en virtud de la buena fe con el acreedor; y por inexistencia de causa justificadora de la omisión, de 4 de febrero de 2009 (RJ 1364/2009); de 27 de septiembre de 2010 (RJ 7140/2010); de 17 de marzo de 2011(RJ 2880/2011); de 19 de mayo de 2011 (RJ 3980/ 20011); de 13 de marzo de 2012 (RJ 4885/2012).

577 En este sentido y explicando estas consideraciones sobre la especial responsabilidad por obligaciones sociales ESTEBAN VELASCO, G., "Algunas reflexiones sobre la responsabilidad de los administradores frente a los socios y terceros: Acción individual y acción por no promoción o remoción de la disolución", cit., pp. 47-78.

${ }^{578}$ Explicando los presupuestos de la responsabilidad por obligaciones sociales, véase SÁNCHEZ CALERO, F., Los administradores, cit., pp. 446-448. 
incumplimiento de los deberes legales ${ }^{579}$. Así que esta responsabilidad por obligaciones sociales supuso que la Ley castigara a los administradores si omitían el deber legal de convocar la junta general para adoptar el acuerdo de disolución, o por la omisión de solicitar el concurso de la sociedad ${ }^{580}$.

En síntesis, los presupuestos para el nacimiento de la responsabilidad son dos: El primero, la omisión del deber legal de la convocatoria de la junta para que se adopte la disolución cuando acontezca causa de disolución, ya que tal omisión impedirá el proceso de liquidación; y, el segundo, que el acuerdo de disolución se deberá ejercitar en el plazo de dos meses desde que se originó la causa de disolución. No obstante, para que se origine esta responsabilidad también se debe acudir a la valoración judicial que se ofrece en cada caso, en concreto, si procede o no atribuir la responsabilidad a los administradores por las deudas de la sociedad $^{581}$.

Una vez expuestos los presupuestos de esta responsabilidad especial se convierte en labor indispensable analizar la casuística jurisprudencial en torno a cómo debería ser el modo de actuar de los administradores, pues pretendemos determinar las conductas del administrador de hecho que justificarían el ejercicio contra ellos de la acción social con la finalidad de que este responda por las deudas de la sociedad.

En esta línea, la jurisprudencia considera en STS de 16 de febrero de 2004 (RJ 648/ 2004) que el simple impago de una deuda no puede significar que los administradores respondan personalmente por las deudas de la sociedad, ni bastaría tampoco que la sociedad

${ }^{579}$ En este sentido señalando los distintos presupuestos entre la responsabilidad por obligaciones sociales y la responsabilidad general por daños las SSTS de 1 de junio de 2010 (RJ 2663/2010) 14 de octubre de 2010 (RJ 866/2010); 23 de diciembre de 2011 (RJ 2012/2011).

${ }^{580}$ Como señala en relación al derogado art.133 LSA, antecedente del actual 236 LSC, nos hallamos ante una norma que impone la responsabilidad civil de los administradores por actos propios, cuando causen daños a la sociedad a los accionistas y a los acreedores sociales, sin embargo la jurisprudencia ha otorgado a este precepto un carácter general más amplio que sirve, en principio, de modulo para determinar los presupuestos de la responsabilidad civil de los administradores, tanto cuando se ejercita la acción social como la individual, véase SÁNCHEZ CALERO F., Los administradores, cit., p. 294.

${ }^{581}$ Culminado la exigencia de la responsabilidad a los administradores, véase SÁNCHEZ CALERO, F., Los administradores, cit., pp. 460-462. 
se encuentre en estado de insolvencia, pues para que opere esta responsabilidad se necesitará, además, que concurran los requisitos que pasaremos a exponer ${ }^{582}$.

El primero, que la sociedad se encuentre en una situación de crisis económica que resulte irreversible cuando el administrador contrató el negocio origen de la obligación impagada, y que se demostrará con aquellas dificultades económicas que obedezcan a un vaciamiento patrimonial de la sociedad. En este sentido también STS de 27 de octubre de $2006\left(\right.$ RJ 8930/2006) ${ }^{583}$.

El segundo ${ }^{584}$, que los administradores conozcan la crisis económica y, a sabiendas del endeudamiento por infra capitalización, contraten con terceros.

El tercero, que los administradores continúen la dirección de la actividad a pesar de que la sociedad carece de bienes para hacer frente al pago de las obligaciones.

El cuarto, que los administradores de derecho o de hecho no informen de la situación de crisis económica a terceros.

En esta sede, el APCM regula la responsabilidad por obligaciones sociales de forma similar a la vigente normativa, aunque con algunas modificaciones significativas que conviene señalar. Así, en los proyectados arts. 272-11 y 272-12 APCM se establece que tal responsabilidad solo operará cuando el administrador no promueva la disolución de la sociedad en el caso de que existan pérdidas en la sociedad, dejando a un lado las otras causas de disolución establecidas en el art. 363 LSC. De este modo, solo surgirá el deber de convocar la junta cuando las cuentas anuales reflejaran pérdidas.

${ }^{582}$ En este sentido, para que, la acción fundada en este supuesto prospere, será preciso, que el demandante aporte suficiente material probatorio, para acreditar la concreta situación económica de la empresa en el momento de la contratación, es decir, mediante oficios a entidades bancarias, examen de cuentas anuales, balances intermedios, información de la Agencia Tributaria y de la Tesorería de la Social, véase STS de 16 de febrero de 2004 (RJ 648/ 2004).

${ }^{583}$ Véase STS de 27 de octubre de 2006 (RJ 8930/2006).

${ }^{584}$ Explicando la infra capitalización en el sentido de falta de financiación ante la incapacidad de obtenerla en el tráfico mercantil, véase OTOXA-ERRARTE GOIKOTXEA, R., "La responsabilidad de los socios por la infra capitalización de la sociedad", $R d S$, núm. 34, pp. 91-104. 
Y, con respecto, a la convocatoria de la junta para adoptar el acuerdo de disolver también el APCM introdujo modificaciones con requisitos específicos: El primero, incluir en el orden del día de la convocatoria la certificación de la aprobación de las cuentas o la propuesta de aumentar o de reducir el capital social. El segundo, que transcurra el plazo de un mes sin haber inscrito el acuerdo de disolución. El tercero, especificar el deber incumplido por el administrador, el cual puede obedecer a dos causas: que no se hubieran formulado las cuentas anuales o que no se incluyeron en el orden del día la convocatoria precisa para adoptarse el acuerdo, y que no se solicitó la disolución de la sociedad. Y, por último, responder por las deudas posteriores al acaecimiento de la causa de disolución ${ }^{585}$.

\subsection{Las causas de disolución}

En su origen, la responsabilidad por obligaciones sociales se centró en la causa de disolución por las pérdidas graves de la sociedad. Sin embargo, el TRLSA de 1989 consideró que era más procedente que se extendiera la aplicación de este régimen de responsabilidad a todas las causas de disolución previstas en los apartados 3, 4, 5 y 7 del art. 260 TRLSA ${ }^{586}$, reproducidas a su vez en el art. 363.1 LSC. No obstante, al trasladar esta responsabilidad especial al administrador de hecho surge el problema de que el poder para convocar la junta es una obligación que corresponde al administrador de derecho, por ser un deber legal. En cambio, el incumplimiento de los deberes legales por el administrador de hecho se determina en función de sus posibilidades de actuación según cuál sea la causa concreta de disolución, precisamente por ser un hecho; por lo que seguidamente abordaremos la problemática de las causas de disolución ${ }^{587}$.

585 Explicando estas reformas, véase QUIJANO GONZÁLEZ, J, "Sociedades mercantiles disolución; sociedades cotizadas", cit., pp. 193-201.

586 Para el nacimiento de la responsabilidad de las deudas sociales y sus presupuestos, véase SÁNCHEZ GARGALLO, I., "La responsabilidad de los administradores pro las deudas de la sociedad. derivadas del incumplimiento de los deberes legales de promover la disolución (artículos 262 LSA y 105 LSRL)”, en AA.VV., Órganos de las sociedades de capital, cit., pp. 1151-1180.

${ }^{587}$ Explicando cada una de las causas de disolución por la concurrencia de los supuestos legales que vienen establecidos en el art. 363 LSC, véase VALPUESTA GASTAMINZA, E., Comentarios a la Ley de Sociedades de Capital, cit., pp. 977-982. 
La primera de las causas de disolución contempladas en el apartado a) del art. 363 $\mathrm{LSC}^{588}$ es la disolución de la sociedad por el cese del ejercicio de la actividad que constituyó el objeto social. Esta causa lleva implícito el problema de dificultad probatoria para lograr su cumplimiento, en particular, si aparece el cese de la actividad por el cierre de hecho de la sociedad $^{589}$. En sentido parecido, nuestra jurisprudencia destacó que el cierre de hecho del domicilio social y la desaparición material de la empresa son unas conductas opuestas a las de un ordenado empresario, en SSTS de 26 de diciembre de 1991 (RJ 9604/1991) y de 4 de noviembre de 2010 (RJ 8868/2010) ${ }^{590}$, pues el cierre sin un proceso de disolución y liquidación impediría que los acreedores puedan satisfacer sus créditos que ostentan contra la sociedad $^{591}$. El problema será su acreditación, porque habrá que recurrir a toda una serie de indicios que nos conducirían a concluir que existe el cese de la actividad.

Estos indicios pueden ser varios, $v$. gr., deduciremos abandono de domicilio social con diligencias de notificación negativa de acuses de recibo devueltos o con actas notariales dando fe del cierre material del domicilio social de la empresa; la falta de constatación registral de la actividad de la sociedad que podría demostrarse a través de otro indicio, como que la sociedad no hubiera presentado las cuentas anuales en el Registro Mercantil, en este sentido SSAP de Pontevedra de 27 de abril de 2015(RJ 149 / 2015), de Asturias de 2 de mayo de 2017 (RJ 119/2017) $)^{592}$; la carencia de propiedades en el Registro de la Propiedad; la certificación negativa de declaraciones impositivas; el certificado de que la sociedad no es contribuyente en la Seguridad Social; la ausencia de vehículos inscritos en la Dirección General de Tráfico; que la sociedad presentara un vacío patrimonial por el hecho de que malbarato sus bienes al traspasarlos gratuitamente a otras sociedades ${ }^{593}$. A estos efectos, resaltamos un ejemplo paradigmático: cerrando la sociedad deudora y descapitalizándola se trasladan sus bienes a

\footnotetext{
${ }^{588}$ En este sentido explicando esta causa, véase MUÑOZ PAREDES, A., Tratado judicial de la responsabilidad de los administradores, cit., pp. 318-319.

${ }^{589}$ Manifestando la dificultad de acreditación de cualquiera de las causas de disolución previstas en el art. 260 LSA, véase, SAENZ GARCÍA DE ALBIZU, J. C., El objeto social en la sociedad anónima, Ed. Cívitas, Madrid, 1990, pp. 348-349.

${ }^{590}$ En torno a este indicio, véanse SSTS de 26 de diciembre de 1991 (RJ 9604/1991); de 4 de noviembre de 2010 (RJ 8868/2010).

${ }^{591}$ En este sentido, véase STS de 14 de marzo de 2007 (RJ 1793/2007).

${ }^{592}$ En este sentido, véanse SSAP de Pontevedra de 27 de abril de 2015(RJ 149 / 2015); de Asturias de 2 de mayo de 2017 (RJ 119/2017).

${ }^{593}$ La disminución del patrimonio social disminuye la garantía de la satisfacción de sus créditos a los acreedores, véase STS de 1 de junio de 2010 (RJ 2663/2010).
} 
otra sociedad nueva con los mismos administradores y el mismo objeto social para eludir el embargo de los bienes de la sociedad que se cerró, disminuyendo así el valor de las participaciones y la garantía de los acreedores para satisfacer sus créditos por la disminución del patrimonio ${ }^{594}$, en este sentido STS de 1 de junio de 2010 (RJ 2663/2010) ${ }^{595}$.

La disolución de la sociedad por la conclusión del objeto social es la segunda causa de disolución de la sociedad prevista en el apartado b) del art. 363.1 LSC. Advertir que, aunque la disolución debería operar automáticamente cuando la sociedad se ha constituido para ejercer una actividad determinada y esta actividad ha finalizado, no obstante, subyace el problema cuando el objeto social tiene el carácter de indefinido. Al respecto, nuestra doctrina se pronunció con posturas contradictorias. Por un lado, un sector doctrinal ${ }^{596}$ sostiene que procedería la disolución de la sociedad automáticamente cuando la conclusión del objeto social afectará a la actividad principal ${ }^{597}$ y, en cambio, otro sector opina que solo operará la disolución si se concluye la actividad principal de todas las demás actividades accesorias que integran el objeto social ${ }^{598}$.

El criterio doctrinal dominante es aquel que considera que debe obligatoriamente disolverse la sociedad por el cese de la actividad principal, pues la omisión de este deber supondría la derivación de responsabilidad a los administradores y, por este motivo, deben ceñirse a la interpretación estricta de la Ley y, en consecuencia, deben proceder a disolver la

${ }^{594}$ En esta línea y para mayor estudio, véase SSTS de 13 de junio (RJ 4763/1996); de 30 de octubre de 1996 (RJ 7486/1996).

${ }^{595}$ Explicando el régimen de la responsabilidad de los administradores de las sociedades en situación de insolvencia, véase PARDO PARDO, J. M., El nuevo régimen de responsabilidad de los administradores de empresas en crisis, cit., pp. 21-25.

${ }^{596}$ Defendiendo esta postura en los supuestos de empresas de explotación de servicios como Expo 92, véase DE EIZAGUIRRE ECHEVARRÍA R., "Disolución y liquidación. Obligaciones" en AA.VV., Comentarios a la Ley de sociedades anónimas, (Dir. SÁNCHEZ CALERO), tomo VIII, Ed. Revista de Derecho Privado, Madrid, 1993, pp. 1016-1018.

${ }^{597}$ Los supuestos de empresas que su objeto social es la explotación de servicio o empresas de concesiones administrativas son supuestos típicos de la conclusión de empresa que constituye el objeto social defendiendo esta postura, véase GARCÍA DE ENTERRÍA, J., "La sociedad anónima: la acción en general", Curso de Derecho mercantil, I, Empresario, establecimiento mercantil y actividad empresarial. Derecho de competencia y de la propiedad industrial e intelectual, derecho de sociedades, Ed. Civitas, Madrid, 1999, p. 1008.

${ }^{598}$ En este sentido defendiendo esta postura, véase SÁENZ GARCÍA DE ALBIZU, J. C., El objeto social en la sociedad anónima, cit., pp. 326-358. 
sociedad $^{599}$. Sin embargo, la jurisprudencia ha entendido, en STS de 18 de marzo de 1996 (RJ 2239/1996), que si su objeto social es amplio no sería obligatorio disolver la sociedad, pues puede continuar con otros bienes o establecimientos mercantiles en otras ramas de su producción, con una ampliación del capital y con un cambio del objeto social ${ }^{600}$.

No obstante, esta causa es más bien residual ya que se encuentra vinculada a la tercera causa de disolución, que se traduce en la imposibilidad manifiesta de conseguir el fin social prevista en el apartado c) del art. 363.1 LSC ${ }^{601}$. La imposibilidad manifiesta de conseguir el fin social deberá ser manifiesta, clara, definitiva, duradera e insuperable, y no consistirá en dificultades transitorias ${ }^{602}$, como las situaciones de infra capitalización o la imposibilidad de poder obtener beneficios ${ }^{603}$.

En cuanto a la causa de disolución por la paralización de los órganos sociales prevista en el aparato d) del art. 363.1 LSC, será una paralización insuperable que implicaría el impedimento total del funcionamiento de una manera permanente pues, a veces, la parálisis del órgano de administración no es un acto decisivo que dificulte que la sociedad funcione, en tanto podrá seguir su marcha a través de la junta de socios; en este sentido STS de 12 de noviembre de 1987 (RJ 8373/1987) ${ }^{604}$.

Las pérdidas cualificadas en la sociedad, prevista en el aparado e) del art. 361 LSC, conocidas también como pérdidas cualificadas o extraordinarias, son las "Pérdidas que dejen reducido el patrimonio neto a una cantidad inferior a la mitad del capital social, a no ser que éste se aumente o se reduzca en la medida suficiente, y siempre que no sea procedente

599 Véase HUERTAS VIESCA, Mà, Y RODRÍGUEZ RUÍZ, D., Responsabilidad de los administradores de las sociedades en crisis, cit., p. 252.

${ }^{600}$ En este sentido, STS de 18 de marzo de 1996 (RJ 2239/1996) declara "que la enajenación de todo el patrimonio social no equivale ni puede dar lugar a la disolución de la sociedad por no concurrir ninguno de los supuestos para disolución de la sociedad"; en contra resolución de la DGRN de 18 de febrero de 199 (RJ 737/1999).

${ }^{601}$ En torno a la aparición de estas causas de disolución, véase MUÑOZ PAREDES, A., Tratado judicial de la responsabilidad de los administradores, cit., p. 319.

${ }^{602}$ La imposibilidad manifiesta de conseguir el fin social para mayor estudio BELTRÁN SÁNCHEZ, E., La disolución de la sociedad anónima, Ed. Cívitas, Madrid, 1991, pp. 108-111.

${ }^{603}$ Explicando el concepto y tipos de infra capitalización, véase OTXA-ERRARTE GOIKOETXEA, R., "La responsabilidad de loso socios por infra capitalización", cit., pp. 140-154; RODRÍGUEZ RUÍZ VILLA, D. Y HUERTAS VIESCA, M. I., Responsabilidades, cit., pp. 496-495.

${ }^{604}$ En esta línea, véase STS de 12 de noviembre de 1987 (RJ 8373/1987). 
solicitar la declaración del concurso". Esta es la causa que despierta mayor interés y la de mayor repercusión en la práctica societaria, pues responde a los presupuestos básicos de la disolución porque las pérdidas cualificadas indicarán el estado de crisis, y aquí los administradores deberán de desplegar el cumplimiento de sus deberes legales en defensa del interés de la sociedad y para evitar que esta termine en un inevitable estado de insolvencia ${ }^{605}$.

Para poder determinar cómo debería ser la actuación diligente de un administrador ante un desequilibrio patrimonial en la sociedad, primero deberemos conocer cuándo la sociedad ha entrado en esta situación de crisis por el desequilibrio económico entre el capital social y el patrimonio neto ${ }^{606}$, ya que la causa de disolución será obligatoria cuando las pérdidas dejen reducido el patrimonio neto a una cifra inferior a la mitad del capital social. No obstante, la doctrina jurisprudencial ha venido sosteniendo, en SSTS de 3 de julio de 1998 (RJ 5214/1998), y 16 de febrero de 2000 (RJ 2679/2000) que, si los administradores incumplieron su deber de disolver la sociedad por esta situación de crisis económica, y los acreedores conocían esta situación, la situación de crisis no sería causa de disolución por sí sola y no determinará el incumplimiento de este deber legal ${ }^{607}$. Sin embargo, este argumento era una

${ }^{605}$ Calificando las pérdidas extraordinarias frente a las perdidas ordinarias Sobre esta causa de disolución como una de las más repercusiones en los administradores BELTRÁN SÁNCHEZ, E., La disolución de la sociedad anónima, cit., pp. 126-149.

${ }^{606}$ Debe recordarse que, como es sabido que el capital social y el patrimonio neto son conceptos muy diferentes. En cuanto al primero, es aquel que constituye uno de los conceptos, más importantes, en la sociedad pues, es el eje fundamental sobre el que se estructurado el régimen jurídico de la sociedad tanto en su aspecto interno como externo y la cifra que se retiene para poder garantizar el pago de las deudas sociales a los acreedores. El patrimonio neto se haya definido en el apartado c) del art. 36.1 del CCom y es la parte residual de los activos de la empresa, una vez, deducidos todos sus pasivos, así que el patrimonio neto será un conjunto de derechos y de obligaciones de valor pecuniario en un momento determinado variable pues se incrementara o reducirá en función de los resultados obtenidos en la sociedad, así que el cálculo del patrimonio neto resultara detrayendo las obligaciones que son exigibles del conjunto de los activos, véanse BELTRÁN SÁNCHEZ, E., Y ROJO FERNÁNDEZ-RÍO, A., "El capital social mínimo. Consideraciones políticas y técnica legislativa" $R d M, 1988$, pp. 149-189; BELTRÁN SÁNCHEZ, E., "La responsabilidad de los administradores por obligaciones sociales", cit., p. 301-352; MUÑOZ MARTÍN, N., "Pérdidas de las sociedades de Responsabilidad limitada", en Estudios de Derecho Mercantil. Homenaje al profesor Justino Fernández Duque, Ed. Valladolid, 1998, pp. 513 y ss.; ORTUÑO BAEZA, M. T., Reducción de capital en la Sociedad Anónima, Ed. Cizur Menor, Navarra 2004, pp. 194 y 195.

${ }^{607}$ El apartado c) del art. 361 CCom a los efectos de la disolución obligatoria por perdidas, el importe que se califique como patrimonio neto según las cuentas anuales será incrementado en el importe del capital suscrito no exigido, así como en el importe del nominal y de las primas de emisión o asunción de capital suscrito que este registrado contablemente como pasivo. No obstante, no se considerará como patrimonio neto a estos efectos, los ajustes por cambio de valor originados en operaciones de cobertura de flujos de efectivo pendientes de imputar a la cuenta de pérdidas y ganancias. En este sentido, véanse SSTS de 3 de julio de 1998 (RJ 5214/ 998); 16 de febrero de 2000 (RJ 2679/2000). 
cuestión controvertida porque seguían creando obligaciones a la sociedad que se encontraba en un estado de insolvencia, aunque los acreedores conocieran los problemas de insolvencia, ya que corrían el riesgo de no poder pagar las deudas de la sociedad, v. gr., la contratación con entidad bancaria conllevaría que a los administradores se les pueda exigir responsabilidades por la falta del pago de la obligación contraída ${ }^{608}$.

\subsection{El requisito del cómputo del plazo}

La interpretación literal del régimen específico de la responsabilidad, que viene previsto en el art. 367 LSC, conduce a que los administradores tengan que convocar la junta general para adoptar el acuerdo de disolución de la sociedad en el plazo de dos meses desde que concurrió la legal causa determinante de disolución, no pudiendo alegar un cumplimiento tardío. A estos efectos, ${ }^{609}$ si los administradores incumplieran dicho plazo automáticamente se desencadenaría la responsabilidad de los administradores por las obligaciones sociales posteriores a la causa de disolución; la jurisprudencia, en STS de 16 de diciembre de 2004 $(8215 / 2004)$, confirma esta consideración ${ }^{610}$. Hay que matizar que en algún caso aislado se ha rechazado esta rigidez legal si existe un desfase de pocos días y seguidamente se procedió a convocar la junta; en este sentido STS de 23 de febrero de 2004 (RJ 1138/20049) ${ }^{611}$. Sin embargo, fijar el inicio del plazo resulta una tarea compleja ${ }^{612}$, porque en el citado precepto no se especifica a partir de qué día empezará a correr el plazo de dos meses para convocar la junta o solicitar el concurso en función de cuál sea la causa de disolución, y cuyo inicio será variable cuando concurre la causa concreta ${ }^{613}$.

\footnotetext{
${ }^{608}$ Para un estudio detallado sobre las cláusulas estatutarias de disolución de la sociedad, véase VALPUESTA GASTAMINZA, E., Comentarios a la ley de sociedades de Capital, cit., pp. 981-983.

${ }^{609}$ Acerca de la interpretación rígida y literal de la norma sobre el plazo de dos meses, véase BELTRÁN SÁNCHEZ, E., "La responsabilidad por obligaciones sociales”, cit., pp. 330.

${ }^{610}$ Confirmando esta interpretación, véase STS de 16 de diciembre de 2004 (8215/2004).

${ }^{611}$ En este sentido, véase STS de 23 de febrero de 2004 (RJ 1138/20049).

${ }^{612}$ Estableciendo que este criterio sobre el inicio del plazo no resulta fácil determinarlo, véase VICENT CHULIÁ, F., "La responsabilidad de los administradores en el concurso", cit., pp. 37-41.

${ }^{613}$ En relación a este problema para mayor estudio véase las abundantes referencias de esta cuestión en RODRÍGUEZ RUÍZ VILLA, D. Y HUERTA VIESCA, Ma ${ }^{\mathrm{a}}$ I., Responsabilidades, cit., pp. 403425 .
} 
Particularmente, en relación con la causa de disolución por pérdidas que dejen reducido el patrimonio neto a una cantidad inferior a la mitad del capital social, la fijación del inicio del cómputo del plazo era una cuestión que no resultaba nada fácil, pues conocer el día en que surgieron las pérdidas es un hecho de difícil prueba debido a que habría que demostrarlo mediante indicios que nos llevaran a la conclusión de cuál fue el momento exacto en que aparecieron. En este sentido señalamos, entre los diferentes indicios que podían concretar este momento, la información que proporciona la contabilidad mediante las sumas y saldos de balances, la información de los balances trimestrales de comprobación, o las cantidades fijadas a cuenta de dividendos ${ }^{614}$. Por su parte, nuestra doctrina a la hora de valorar esta cuestión no ha conseguido un criterio unánime.

La doctrina mayoritaria se inclina por un plazo que empezará a contarse a partir del momento en que la junta ha aprobado las cuentas anuales del ejercicio que detecta pérdidas o, en su defecto, desde la formulación de las mismas, concluyendo que el plazo empezaría a correr desde la fecha límite para formular las cuentas anuales y que sigue siendo el plazo de tres meses desde la fecha del cierre ${ }^{615}$.

En cambio, la corriente doctrinal minoritaria ha sostenido que la determinación del dies a $q u o^{616}$ sería desde que el administrador ha conocido el importe de las pérdidas con la información que ofrecen los documentos contables y los balances intermedios. Sin embargo, esta solución no fue acogida por nuestro sistema legal y, por esta razón, la doctrina sigue considerando que habría que atenerse al momento de la formulación de las cuentas anuales debido a que es el momento en el que se detectaron las pérdidas ${ }^{617}$.

Esta cuestión polémica ha sido resuelta por la jurisprudencia, que ha confirmado tal y como establece la Ley, en SSTS de 23 de octubre de 2008 (86/2008), 14 de julio de 2010 (RJ

\footnotetext{
${ }^{614}$ En esta línea de desarrollo BATALLER GRAU, F., “Artículo 363”, en AA.VV., Comentarios de la Ley de sociedades de capital, cit., pp. 2547-2559.

615 En este sentido, véase ROJO FERNÁNDEZ-RÍO, A., "Los deberes legales de los administradores en orden a la disolución de la sociedad de capital como consecuencia de perdidas", cit., pp. 1462 y ss.

${ }^{616}$ Sobre la problemática del plazo bimensual en esta responsabilidad, véase RODRÍGUEZ RUÍZ VILLA, D. Y HUERTA VIESCA, Ma . I., Responsabilidades, cit., pp. 505-507.

${ }^{617}$ En torno al cumplimiento tardío de este plazo para acordar la disolución véase BELTRÁN SÁNCHEZ, E., "La responsabilidad de los administradores sociales”, cit., pp. 329-330.
} 
460/2010), 17 de marzo de 20011 (RJ 173/2011) y de 23 de noviembre de 2011 (RJ 826/2011), que el dies a quo empezaría a contar desde que los administradores conocieron o debieron conocer la situación económica de la empresa. La justificación de este argumento estriba en que los administradores tienen la obligación de informarse diligentemente de la marcha de la sociedad, lo que les obliga a conocer la causa de disolución ${ }^{618}$. De ahí que el dato decisivo para computar el plazo de los dos meses no se puede reconducir a cuándo el administrador conoció el resultado de las cuentas anuales, sino que más bien deberá empezar a computarse desde el momento en que el administrador tuvo conocimiento de las pérdidas, o de aquella situación que produjo el desequilibrio económico entre el capital social y el patrimonio neto. La jurisprudencia añade, en SSTS de 16 de diciembre de 2008 (RJ 1219/2008), de 30 de octubre de 2000 (RJ 977/2000) y de 18 de julio de 2002 (RJ 766/2002), que el inicio del cómputo deberá ser cuando en la sociedad se produce el hecho objetivo de la causa de disolución, que es el momento que conducirá al administrador a convocar la junta para disolver la sociedad, debido a que esta es la regla que rige en este tipo de responsabilidad $^{619}$. El administrador diligente tiene el deber de conocer la existencia de pérdidas sin la necesidad de documento contable y, por esta razón, se rechaza que el dies a quo empiece a contar desde que el administrador pudo haber conocido las pérdidas.

\subsection{La presunción de las deudas posteriores a la causa de disolución}

Otra cuestión que reviste vital importancia en la práctica societaria es la relativa al segundo elemento de la responsabilidad por obligaciones sociales y que se concreta exactamente en el art. 367 LSC, solo con respecto a las deudas posteriores al acaecimiento de la causa de disolución con una presunción iuris tamtun, "Las deudas sociales se presumirán de fecha posterior al acaecimiento de la causa de disolución salvo que los acreedores acrediten que son de fecha anterior"; por lo que no responderán por estas deudas de la sociedad. De ahí que la cuestión a dilucidar es precisar cuándo nació la deuda de la sociedad,

${ }^{618}$ En este sentido, véanse SSTS de 23 de octubre de 2008 (86/2008); 14 de julio de 2010 (RJ 460/2010); 17 de marzo de 20011 (RJ 173/2011); de 23 de noviembre de 2011 (RJ 826/2011), que establecen el plazo de dies a quo para el ejercicio de esta acción, dada la falta de previsión legal en el momento de que el administrador tuvo el conocimiento de la crisis en la empresa.

${ }^{619}$ Véanse SSTS de 16 de diciembre de 2008 (RJ 1219/2008); de 30 de octubre de 2000 (RJ 977/2000); de 18 de julio de 2002 (RJ 766/2002). 
antes o después de la causa de disolución, pues los administradores solo responden de las deudas sociales posteriores.

$\mathrm{Al}$ respecto, nuestra doctrina considera que el criterio para concretar el nacimiento de la deuda es el que se establece en las normas generales del Código Civil, que nacen desde la perfección del contrato (art. 1262 CC) y no desde su consumación. No obstante, estas normas generales de las obligaciones y contratos no pueden servir para resolver la problemática que dimanan de las obligaciones sociales, ya que aunque la deuda surgió antes de la causa de disolución, posteriormente esta se puede convertir en un caso de litigio y, en ese supuesto, si resulta que es una deuda de la sociedad, se encontrará dentro del periodo posterior a la causa de disolución, como las deudas que nacen de un contrato de tracto sucesivo con prestaciones realizado antes y después de la causa de disolución, o cuando la deuda nace en una fecha anterior a la causa de disolución y se nova en una fecha posterior a la causa de disolución.

Sin embargo, los supuestos mencionados anteriormente se refieren más bien a cuándo sería exigible. El criterio consolidado por nuestra doctrina es aquel que sostiene que solo nacen las obligaciones desde la perfección del contrato, y por esta razón quedan al margen de responsabilidad aquellas obligaciones que son periódicas e incluso aquella deuda que ha sido declarada en una sentencia posterior, pues lo que determinará el nacimiento de la deuda es la fecha de la perfección del contrato origen de la deuda ${ }^{620}$.

\section{Extensión de la responsabilidad por obligaciones sociales al administrador de hecho}

\subsection{La distinción entre responsabilidad por daños y por obligaciones sociales}

Llegados a este punto, para poder entender cuál es la esencia de la responsabilidad por obligaciones sociales y su alcance subjetivo al administrador de hecho, conviene recordar la distinción entre estas dos responsabilidades de los administradores. La primera, denominada por daños, que como ya es sabido viene regulada en el art. 236.1 LSC y, por otro, la responsabilidad objetiva por obligaciones sociales regulada en el art. 367 LSC. Las

620 Resolviendo estas cuestiones, véase MUÑOZ PAREDES, A., Tratado judicial de la responsabilidad, cit., pp. 398-433. 
principales diferencias entre ambas se centran en sus distintas naturalezas, la primera de corte indemnizatorio y la segunda de tipo sancionador.

El carácter indemnizatorio de la responsabilidad general de los administradores radica básicamente en que cuando acontece un daño por incumplimiento de los deberes inherentes al desempeño del cargo, contra la Ley o los estatutos, los administradores responden reparando el daño. En cambio, la responsabilidad por obligaciones sociales nace cuando se omitiera la orden de promover la convocatoria de la junta general para adoptar la oportuna disolución de la sociedad o, en su caso, el deber de solicitar el concurso de la sociedad y los administradores son sancionados respondiendo personalmente por las deudas de la sociedad ${ }^{621}$.

Por estas razones, la responsabilidad por daños tiene un ámbito objetivo mucho más amplio que el de la responsabilidad por obligaciones sociales, pues la primera se activará si se producen daños a la sociedad o terceros con la acción social, y en su caso con la acción individual. En cambio, el ámbito de la responsabilidad por obligaciones sociales será más reducido, pues solo se activará por la acción del art. 367 LSC si se infringieran sus propios presupuestos $^{622}$. Dicho ámbito reducido se constata porque se resarcirá a los acreedores con limitación en el tiempo, pues los administradores solo responden por las deudas sociales acaecidas con posterioridad a la causa de disolución, sin embargo, con la responsabilidad por daño se resarce a los acreedores por cualquier daño que resultara del incumplimiento de la Ley de los estatutos o de los deberes inherentes al desempeño de su cargo, concurriendo dolo o culpa ${ }^{623}$.

De modo que la distinción fundamental entre ambas se encuentra en el elemento intencional, pues la responsabilidad general es subjetiva por culpa o dolo. Y, en cambio, en la responsabilidad por obligaciones sociales los elementos intencionales del dolo o de la culpa no tendrían la misma aplicación, en tanto que solo necesita que los administradores omitieran

\footnotetext{
${ }^{621}$ Explicando los presupuestos de este tipo de responsabilidad, véase BELTRÁN SÁNCHEZ, E., "La responsabilidad de los administradores", cit., pp. 331-351.

${ }^{622}$ Véase QUIJANO GONZÁLEZ, "La responsabilidad de los administradores por no disolución de la sociedad: Art. 262.5 TRLSA, SAP Burgos de 24 de julio de 1995”, RdS, núm. 5, 1995, pp. 265-282.

${ }^{623}$ En torno a las diferencias entre ambas responsabilidades, véase CAMPUZAMO LAGILLO, A. B., "La acción social de responsabilidad. Artículos 238 a 240 de la Ley de sociedades de capital", cit., p. 829.
} 
determinados deberes específicos y la existencia de deudas sociales que la sociedad no atendió $^{624}$.

Otra de las diferencias estriba en la legitimación para su ejercicio, ya que la acción de responsabilidad por obligaciones sociales se halla reservada a los acreedores que solo necesitarán acreditar el incumplimiento del deber específico en un determinado plazo y la existencia de un crédito no satisfecho ${ }^{625}$. En cambio, en la responsabilidad por daños la jurisprudencia exige, en SSTS de 21 de septiembre de 1999 (RJ 730/1999) y de 20 de julio de 2001 (RJ 6863/2001) ${ }^{626}$, una conducta o actitud ilícita, hechos, actos u omisiones de los administradores carentes de la diligencia de un ordenado comerciante, y que bastará una mera negligencia que diera lugar a un daño, el cual deberá probarse por el perjudicado. En cambio, en la responsabilidad por obligaciones sociales, como se indica en las SSTS de 12 de noviembre de 1999 (RJ 9045 /1999) y de 20 de diciembre de 2000 (RJ 9909/2000) ${ }^{627}$, solo se requiere la prueba de la omisión del deber legal en el plazo de dos meses para que se origine la efectividad de la sanción legal. Y en este sentido, se sostuvo que la acción se ejercitará sólo por los acreedores con una acción autónoma que no necesita demostrar la relación de causalidad entre su incumplimiento y el resultado producido ${ }^{628}$.

${ }^{624}$ Señalando la distinción entre el dolo como conciencia del significado del acto ilícito y voluntad de realizarlo y la culpa como omisión de la diligencia debida, véase ESTABAN VELASCO, G., La acción individual de responsabilidad, cit., pp. 189- 272.

${ }^{625}$ Explicando el fundamento de esta responsabilidad por el pago de las deudas de la sociedad, véase GARCÍA-CRUCES GONZÁLEZ, J. A., "La responsabilidad de los administradores por no promoción o remoción de la disolución de la sociedad: consideraciones al debate jurisprudencial", cit., p. 27.

${ }^{626}$ Estableciendo la clara diferencia entre ambas acciones, véase las SSTS de 21 de septiembre de 1999 (RJ 730/1999) y de 20 de julio de 2001 (RJ 6863/2001).

${ }^{627}$ En relación, a la responsabilidad por obligaciones sociales SSTS de 12 de noviembre de 1999 (RJ 9045 /1999) y de 20 de diciembre de 2000 (RJ 9909/2000).

${ }^{628}$ Desde el punto de vista jurisprudencial se trata de una responsabilidad cuasi objetiva o, incluso, objetiva, al estar basada en un hecho objetivo, la omisión de la convocatoria de la Junta o de la solicitud del concurso, sin atender a la calificación de la conducta culposa o diligente del administrador en el ejercicio del cargo pues no se basa en la relación de causalidad entre un determinado acto lesivo, es decir, es la falta de disolución por cualquier causa de las previstas en la Ley que derive en la insolvencia de la sociedad. En este sentido, véanse STSS de 15 de julio de 1997 (RJ 5609/1997); de 29 de abril de 1999 (8697/1999); de 30 de octubre de 2000 (RJ 9909/2000); de 28 de abril de 2006 (RJ 4087/2006), de 14 de octubre de 2013 (RJ 6948/2013. En este sentido también, RODRÍGUEZ ARTIGAS, F., "Algunas cuestiones sobre la responsabilidad de los Administradores de Sociedades Anónimas por no promoción de la disolución en caso de pérdidas (art. 262.5 LSA). STS sección $1^{\text {a }}$ de 16 de diciembre de 2004", $R d S$, núm. 24, 2005, pp. 295 y ss. 
No obstante, con esta acción no se debería de prescindir del elemento intencional de la culpa, pues lo que se sanciona es que el administrador permitió, con la omisión de sus deberes legales, que la sociedad continuara incursa en causa de disolución, bajo una apariencia ante los acreedores de que la sociedad es solvente y que tiene una regularidad patrimonial. En esta misma línea, la doctrina jurisprudencial, en SSTS de 16 de febrero de 2000 (RJ 679/2000) y de 7 de febrero de 2002 (RJ 781/2002) ${ }^{629}$, fue paulatinamente dulcificando el rigor objetivo de la responsabilidad, incluyendo algunos matices culpabilísticos que servirían para poder valorar el modo de actuar de los administradores ante las situaciones de crisis de la sociedad, sosteniendo que se debería valorar la actuación del acreedor que, a sabiendas de la insolvencia, admitiría contraer obligaciones con la sociedad ${ }^{630}$.

Por tanto, en algunos supuestos se debería de tener en cuenta la conducta de los administradores ante la situación de crisis en la sociedad, a lo que habría de añadirse el conocimiento del acreedor de esa situación ${ }^{631}$. No obstante, el criterio consolidado por la jurisprudencia fue continuar considerando que se trataba de una responsabilidad objetiva con efectos meramente sancionadores ${ }^{632}$, salvo que los administradores demostrasen que efectuaron una "acción significativa" para evitar el daño; en este sentido SSTS de 1 de junio de 2009(RJ4315/2009) y de 12 de febrero de 2010 (RJ 534/2010) ${ }^{633}$.

${ }^{629} \mathrm{El}$ conocimiento por parte del acreedor de la situación de crisis de la empresa puede atemperar la responsabilidad del administrador, en esta línea SSTS de 16 de febrero de 2000 (RJ 679/2000); de 7 de febrero de 2002 (RJ 781/2002).

${ }^{630}$ Sobre el cumplimiento de los deberes legales, véase BELTRÁN SÁNCHEZ, E., La responsabilidad de los administradores, cit., pp. 236-239.

${ }^{631}$ En esta línea se excluía la responsabilidad en función de la actuación significativa de aumentos de capital en la sociedad para atenuar o excluir de responsabilidad a los administradores, véanse SSTS de 4 de febrero de 2009 (RJ 1364/2009); de 19 de mayo de 2011 (RJ 3980/2011); de 13 de marzo de 2012 (RJ 4885/2012).

${ }^{632}$ El carácter de responsabilidad cuasi objetiva se afirma de forma cuasi unánime en la propia jurisprudencia menor, siguiendo la doctrina emanada de la doctrina jurisprudencial de SSTS de 16 de julio de 2002 (RJ 8710/2002); 23 de octubre de 2003 (RJ 7513/2003).

${ }^{633}$ Aquí aparece una imputación a los administradores de carácter subjetiva, véase SSTS de 1 de junio de 2009(RJ4315/2009) y de 12 de febrero de 2010 (RJ 534/2010). 


\subsection{La extensión por obligaciones sociales al administrador de hecho}

Trazar el camino para que se pueda exigir responsabilidad por incumplimiento de las obligaciones sociales al administrador de hecho es uno de nuestros objetivos principales. Objetivo complejo por dos razones: la primera, por su falta de designación formal para cumplir con los deberes legales y, la segunda, porque el incumplimiento de estos deberes determinará que el administrador de hecho responda personalmente por las deudas de la sociedad. Hay que tener presente que el legislador solo menciona al administrador de hecho en la responsabilidad por daños, y omite toda referencia al mismo en la responsabilidad por deudas en el art. 367 LSC $^{634}$. No obstante, al extender el régimen jurídico de la responsabilidad general de los administradores al concepto de administrador de hecho, definido en el art. 236. 3 LSC por su modo de actuar, las disposiciones de los deberes de los administradores les serán también aplicables en cualquiera de sus manifestaciones, incluida la oculta.

Sin embargo, en un principio se consideró que tal omisión en la Ley se debía a que el administrador de hecho no podía responder de no hacer algo si no se hallaba legalmente capacitado $^{635}$; aunque otro sector se pronunciaba sobre dicho olvido explicando que cabía la aplicación de esta responsabilidad al administrador de hecho ${ }^{636}$, porque la naturaleza de esta responsabilidad en el art. 367 LSC es sancionadora, al castigar tanto la omisión del deber de convocar a la junta como al administrador que contraiga nuevas obligaciones con una sociedad que se encuentra en un estado de crisis económica ${ }^{637}$. Por estas razones, defendían que el administrador de hecho también debería responder por las deudas de la sociedad porque realizaba funciones de administrador de forma negligente cuando, a sabiendas de que

${ }^{634}$ Reflexionando acerca de la responsabilidad del administrador de hecho por las deudas de la sociedad, véase RODRÍGUEZ SÁNCHEZ, S., "La responsabilidad del administrador de hecho", cit., pp. 154-156.

${ }^{635}$ En este sentido, véanse JUSTE MENCÍA, J., "En torno a la aplicación del régimen de responsabilidad a los administradores", cit., pp. 455; SÁNCHEZ CALERO, F., Los administradores, cit., pp. 458-459.

${ }^{636}$ Argumentando como podría actuar la figura del administrador de hecho BELTRÁN SÁNCHEZ, E., "La responsabilidad de los administradores por obligaciones sociales", cit., pp. 273-274.

${ }^{637}$ Véanse RODRÍGUEZ RUÍZ VILLA, D. Y HUERTA VIESCA, M. I., Responsabilidades de los administradores, cit., 2013, pp. 194-195; LATORRE CHINER, N., "El concepto de administrador de hecho", cit., p. 897; MACHADO PLAZAS, J., Pérdida del capital social y responsabilidad de los administradores por deudas sociales, Ed. Cívitas, Madrid, 1997, pp. 340-341. 
la sociedad era insolvente, continuaba desarrollando la actividad agravando de este modo su estado de insolvencia.

En esta misma línea, otro sector doctrinal basaba la posible aplicación de la responsabilidad por obligaciones sociales a los administradores de hecho en la obligación de cumplir con "los deberes inherentes al desempeño de su cargo" contemplada en el art. 236.1 LSC. Así, consideraban que el cumplimiento de los deberes legales que establece el art. 367 LSC también englobaba el deber general de actuar con diligencia, lo que se traduce en que los administradores de hecho deben cumplir con los mismos deberes legales que se les exige a los de derecho; por citar un ejemplo, cuando mediante la Junta Universal se adopta el acuerdo de disolución de la sociedad. Para justificar estas consideraciones ese sector doctrinal sostenía que el administrador de hecho, ya sea directa o indirectamente, e incluso a través de los socios, debería de intentar celebrar una Junta Universal para que se adoptara el acuerdo de disolución o, en su caso, en qué medida el administrador de hecho participó para que se cumplieran los deberes legales, o qué medidas fueron las oportunas para que el administrador de hecho actuara ante la situación de crisis con el fin de no agravar aún más la insolvencia ${ }^{638}$, pues resultaba irrelevante que la omisión hubiera sido realizado por el administrador de derecho o por el de hecho ${ }^{639}$.

Sin embargo, a sensu contrario, otro sector consideraba que con la aplicación directa de las obligaciones previstas en el art. 236 LSC no cabía interpretar que el administrador de hecho es responsable por la omisión de los deberes legales y, sobre todo, que no resultaría sancionado con esta responsabilidad por deudas sociales, ya que entendían que los administradores de hecho no podrán responder por no hacer algo cuando no estaban capacitados para poder realizarlo ${ }^{640}$.

638 Al respecto, PABLO-ROMERO GIL-DELGADO, Ma . C., "Responsabilidad de los administradores de sociedades por no haber instado el concurso ¿un supuesto asegurable?", cit., p. 317.

${ }^{639}$ En este sentido, véase MARTÍN SANZ, F. “Ámbito subjetivo de la responsabilidad”, en AA.VV., La responsabilidad, cit., pp. 55-77.

${ }^{640}$ En este sentido, ver el detallado comentario de JUSTE MENCÍA, J., "En torno a la aplicación del régimen de responsabilidad" cit., pp. 441-457; LATORRE CHINER, N., El administrador de hecho, cit., pp. 1 y ss.; FUENTES NAHARRO, M., "La funcionalidad de la figura del administrador de hecho", cit., pp. 304-307. 
Nuestra jurisprudencia, en STS de 28 de abril de 2006 (RJ4087/2006), confirmaba esta última corriente argumentando que, si el legislador había mantenido la omisión del administrador de hecho como responsable en el art. 367 LSC, este mandato legal era más que suficiente para no dirigir la acción de responsabilidad por obligaciones sociales contra los administradores de hecho ${ }^{641}$.

De modo que la Ley acogió la primera tesis planteada al inicio de este apartado, no solo para poder definir la figura del administrador de hecho en sentido amplio sino que además ha servido para imputar la responsabilidad a los administradores de hecho en el vigente art. 236.1 LSC y, asimismo, para determinar que la responsabilidad por obligaciones sociales del art. 367 LSC resultaría igualmente aplicable a todos los administradores de la sociedad, pues no se hacía ni se ha hecho diferenciación entre el administrador de derecho y el de hecho para cumplir con aquellas obligaciones que se establecen el art. 367 LSC.

No obstante, nuestra doctrina más reciente ha puesto de nuevo en tela de juicio esta eterna polémica que hasta este último hito legislativo se ha venido cuestionando, en torno a si la responsabilidad prevista en el art. 367 LSC se podría exigir también al administrador de hecho debido a su falta de nombramiento por parte de la sociedad ${ }^{642}$. En esta línea, un sector doctrinal ha venido a considerar que los deberes de los administradores deben aplicarse al de hecho en sentido restringido, y tan solo en su manifestación oculta. Así, tales deberes no deben aplicarse al administrador de hecho denominado aparente ${ }^{643}$. Su justificación estriba en que esta figura del administrador de hecho aparente conlleva una forma de actuar que solo implica injerencias ajenas en las facultades que son propias de los administradores. En cambio, en el administrador de hecho oculto, por su modo de actuar, es el que imparte instrucciones que son aceptadas sistemáticamente por los administradores formales de la sociedad que directamente las ejecutan sin discusión alguna. Por ello, consideramos que el administrador de hecho conocía que la sociedad necesitaba de la disolución sino se

${ }^{641}$ STS de 28 de abril de 2006 (RJ4087/2006), y para mayor estudio, véase HUERTA VIESCA, Mª I., Y ROBRÍGUEZ RUÍZ, D., Responsabilidades de los administradores, cit., pp. 194 y ss.

${ }^{642}$ Aplicando la responsabilidad por obligaciones sociales al administrador de hecho, véase, BELTRÁN SÁNCHEZ, E., "La responsabilidad de los administradores por obligaciones sociales", cit., pp. 348-349. Cuestionando la exigencia de esta responsabilidad al administrador de hecho, véase MUÑOZ PAREDES, A., Tratado judicial de la responsabilidad, cit., pp. 115-128.

643 Explicando estas diferencias para aplicar los derechos de los administradores solo al administrador de hecho oculto, véase HERNANDO CEBRIÁ, L., "Presupuestos del deber de lealtad, artículo 227.1”, cit., pp. 152 y 153. 
encontraría en situación de insolvencia y, por tanto, el administrador de hecho oculto debería de emitir las órdenes oportunas a los administradores formales que ostentan la legitimación formal para convocar la junta general con la finalidad de adoptar el acuerdo de la disolución.

Sin embargo, se ha venido afirmando que a los administradores de hecho solo se les exigiría el cumplimiento del desarrollo de las actividades positivas de gestión, no pudiendo exigirles responsabilidad por incumplir las normas que atañen a los deberes formales, como pueden ser publicaciones o convocatorias de la junta general. Por ello, consideraban que el administrador de hecho oculto quedaría excluido de responsabilidad por actos de omisión debido a que carece de designación por la sociedad para realizar el cumplimiento de estos deberes legales. En este mismo sentido, la doctrina del derecho comparado en Francia conformaba esta doctrina de la responsabilidad in ommittendo de los administradores de hecho, al considerar que quedarían excluidos de responsabilidad por la omisión de los deberes legales, ya que esta condición solo se puede alcanzar por un comportamiento positivo dirigiendo de hecho a la sociedad y, en consecuencia, con abstenciones u omisiones no podrían dirigir efectivamente la sociedad ${ }^{644}$.

En sentido contrario, otra corriente doctrinal anterior no distinguía entre las distintas manifestaciones del administrador de hecho aduciendo que estos debían responder tanto por su actuación positiva como por las omisivas. Para defender esta postura argumentaban que, si el administrador de hecho debía responder por no hacer lo que le corresponde en la responsabilidad general de los administradores también deberán responder por el incumplimiento de los deberes impuestos por la Ley, como podría ser la omisión del deber de solicitar la convocatoria de la junta general para poder adoptar el acuerdo de la disolución de la sociedad o, en su caso, el deber de solicitar el concurso de la sociedad, pues por su equiparación al administrador societario si no cumple con esta obligación legal, según se establece en el art. 367 LSC, debería de responder personalmente por las deudas de la

${ }^{644}$ Defendiendo esta tesis, véase LATORRE CHINER., N., El administrador de hecho, cit., p. 159189. La doctrina que mantenía esta postura era aquella que entendía que no se podían aplicar todos los deberes de los administradores al supuesto del administrador de hecho automáticamente y que además que se requería que se hubiera establecimiento de un régimen específico que indique los deberes a los que se encontraba sometido, En este sentido explicando esta teoría en el derecho comparado francés, véase RIVES-LANGE, J. L., "La notion de dirigeant de fait au sens de l' article 99 de la loi du 13 juillet 1967 sur le reglament judiciare et la liquidation des biens", en Rec. Dalloz, 1975, pp. 44; FUENTES NAHARRO, N., "La funcionalidad del administrador de hecho", cit., p. 17. En sentido contrario, y considerando al administrador de hecho como responsable en la misma forma que un administrador de derecho, DÍAZ ECHEGARAY, J. L., El administrador de hecho, cit., pp. 187-189. 
sociedad a pesar de que nunca ha venido obligado a tener que solicitar el concurso ${ }^{645}$. Recordar que la Ley de Trasparencia no incluyó al administrador de hecho en el art. 262.5 TRLSA; ni en la LSC y las siguientes reformas se modificó el art. 367 LSC, ni tan siquiera la Ley 31/2014. Por tanto, sigue plateándose si al administrador de hecho le corresponde el cumplimiento de la obligación legal de solicitar la declaración del concurso.

No obstante, se consideraba que el administrador de hecho quedaba sometido a la obligación de solicitar la declaración del concurso de la sociedad porque esta obligación era una orden impuesta a todos los administradores que ejercían las funciones propias de los administradores $^{646}$, con base en otro sector doctrinal que esgrimía el argumento siguiente: el art. 3.1 LC establece que la decisión de solicitar el concurso de la sociedad corresponde al órgano de administración, de modo que el administrador de hecho estaría obligado a solicitar la declaración del concurso de la sociedad ${ }^{647}$.

Así pues, procede exigir la responsabilidad al administrador de hecho por omitir la obligación de solicitar el concurso, fundamentalmente porque los administradores de hecho están legitimados en el art. 3.1 LC, pues por su modo de actuar les corresponde ser titular del órgano de administración. Esta misma línea doctrinal también se apoyaba en el art 3.3 LC que establece que los administradores, por ser integrantes de la sociedad, implicaría la inclusión de los administradores de hecho como responsables por las deudas sociales ${ }^{648}$.

Por consiguiente, si bien este deber legal de actuación previsto en el art. 367 LSC no hace una mención expresa del administrador de hecho, sin embargo, este encajaría dentro del ámbito subjetivo de la responsabilidad por deudas sociales por no proceder a la convocatoria de la junta para disolver la sociedad; lo que se traduce en que los administradores de hecho

${ }^{645}$ En este sentido, véase el análisis detallado de la obra de PABLO ROMERO-GIL DELGADO, $\mathrm{M}^{\mathrm{a}}$. C., "La responsabilidad de los administradores de sociedades por no haber instado el concurso, ¿un supuesto asegurable?", cit., pp. 317.

${ }^{646}$ La incidencia de la aparición de la responsabilidad por no haber solicitado la declaración del concurso de sociedades que se encuentran insolventes, RODRÍGUEZ RUÍZ VILLA, D. Y HUERTA VIESCA, Mª. I., Responsabilidad de los administradores, cit., pp. 599-657.

${ }^{647}$ En este sentido y admitiendo que el administrador de hecho está obligado a solicitar el concurso, DE LA TORRE CHINER, N., "El concepto de administrador de hecho", cit., pp. 897-898.

${ }^{648}$ En este sentido, véase la corriente establecida por la doctrina en RODRÍGUEZ RUÍZ VILLA, D. Y HUERTA VIESCA, Mª. I., Responsabilidad de los administradores, cit., pp. 2003-2004. 
resultarán responsables por omitir la obligación legal de solicitar el concurso de la sociedad cuando se encuentra en estado de insolvencia ${ }^{649}$.

No obstante, tal y como hemos venido señalando, hubiera sido más correcto que la Ley hubiera dispuesto una disciplina específica que regulara el régimen jurídico de la responsabilidad del administrador de hecho concretando las disposiciones normativas y los deberes legales que debe cumplir, y no simplemente una aplicación automática de todos los deberes de los administradores en el art. 236.3 LSC, cuando se definió su concepto legal en los presupuestos y en los criterios de imputación de la responsabilidad general de los administradores regulados en el art. 236. $1 \mathrm{LSC}^{650}$.

En síntesis, la LSC dejó abierta la posibilidad a que el administrador de hecho tenga que explicar en cada caso concreto sus posibilidades de actuación para cumplir con los deberes legales y con los inherentes al desempeño del cargo que se establecen en nuestra legislación societaria $^{651}$. Esto se traduce en que para exigir responsabilidad a un administrador de hecho en sus distintas manifestaciones dependerá, en gran medida, de las posibilidades reales que tuvo en un determinado momento para actuar y cumplir con las obligaciones legales, a fin de que no tenga que responder personalmente por las deudas sociales conforme establece el art. $367 \mathrm{LSC}^{652}$.

\section{Coordinación entre la responsabilidad societaria y la concursal}

La crisis empresarial, como es sabido, desencadenó reformas en sede de exigencia de responsabilidad, en particular en relación con el administrador de hecho, lo que nos han llevado a un primer planteamiento que consiste en dilucidar si cuando las sociedades se

${ }^{649}$ En este sentido, véanse SSAP de Zamora 19 de junio de 2015 (RJ109/2015); de Murcia de 8 de septiembre de 2016 (RJ 429/016).

${ }^{650}$ En esta línea, véase LATORRE CHINER N., El administrador de hecho, cit. 188-189.

${ }^{651}$ Sobre cómo se debería de aplicar esta responsabilidad a la figura del administrador de hecho, véase RECAMAN GRAÑA, E., "Los deberes y la responsabilidad de los administradores", cit., pp. 334-340.

${ }^{652}$ En este sentido, véase LATORRE CHINER, N., "EL concepto de administrador de hecho", cit., p. 895 . 
encuentran en una situación de insolvencia debe acudirse al derecho societario o concursal ${ }^{653}$. En este contexto, se ha venido originado una legislación oscura y compleja que ha dado lugar a que nuestra doctrina y jurisprudencia tuvieran que plantearse de nuevo un esfuerzo exegético para resolver las controversias que se suscitaron en la responsabilidad de los administradores ${ }^{654}$. A tal fin, intentaremos concretar cuándo la Ley sancionará a los administradores por llevar a la sociedad a una situación de insolvencia por no solicitar la convocatoria de la junta para disolver la sociedad, y cuando los administradores deberán solicitar la declaración del concurso para evitar que se produzca una agravación del estado de insolvencia de la sociedad ${ }^{655}$, es decir, coordinar la responsabilidad societaria y las concursales ${ }^{656}$.

Como es sabido, el régimen de la responsabilidad por obligaciones sociales dispone que si existen pérdidas cualificadas y, si fuese procedente, los administradores deben solicitar la declaración del concurso. Este deber legal ya fue introducido por la Ley 22/2003, de 9 de julio, en el derogado art. 260.2 TRLSA. Por otro lado, en sede concursal también se refleja la obligación en los arts. 3 y 5 LC que establecen que el órgano de administración deberá decidir la solicitud del concurso ante una situación de insolvencia en la sociedad. La causa de que en nuestro sistema se halla impuesto esta doble imposición, ante una situación de pérdidas graves, obedecía a la pretensión de garantizar que los créditos de los acreedores fueran

${ }^{653}$ Acerca de las consecuencias de la responsabilidad de los administradores tras reforma de la LSC, véase MOYA JIMÉNEZ, A., La responsabilidad de los administradores de empresas insolventes. Adaptada a la Ley 25/2011, de 1 de agosto, y la Ley 38/20011, de 10 de octubre, de reforma de la LC y la modificación de la LSC por el RDL 9/2012 de 16 de marzo, que modifica la ley de sociedades de capital, Ed. Bosch, Barcelona, 2012, pp. 64-76.

${ }^{654}$ Más reforma sobre la responsabilidad de los administradores modificando la Ley Concursal como la Ley 14/2013 de 27 de septiembre, para adaptar el apoyo a los emprendedores y sus intermediarios, véase MOYA JIMÉNEZ, A., La responsabilidad de los administradores de empresas insolventes. Adaptada a la Ley 14/2013, de 27 de septiembre, de apoyo a los emprendedores y su internalización, Ed. Bosch, Barcelona, 2014, pp. 104-109.

655 Sobre los argumentos para justificar la solicitud del concurso y la conducta de los administradores, véase, MORENO SERRANO, E., Los administradores de una sociedad de capital ante una situación de insolvencia, Ed. La Ley, Madrid, 2015, pp. 23-78.

${ }^{656}$ La responsabilidad de los administradores en situaciones de crisis económica en la sociedad, véase MOYA BALLESTER, J., La responsabilidad de los administradores de sociedades en situaciones de crisis, Ed. La Ley, Madrid, 2010, pp. 111-129. 
satisfechos si los administradores omitieran estos deberes legales, pues responderían solidariamente con la sociedad por sus deudas sociales ${ }^{657}$.

En particular, con respecto al administrador de hecho en sede concursal, cuando incumplía este deber legal de solicitar el concurso se le condenaba porque, a sabiendas de que la sociedad se encontraba en situación de insolvencia, no solicitó su concurso en el plazo de dos meses agravando así su estado de insolvencia. Por su parte los acreedores, buscando los medios para poder satisfacer sus créditos, se encontraban con disposiciones que estaban a caballo entre las normas del ámbito societario y las concursales, las cuales además contemplaban un régimen jurídico diferente para exigir responsabilidades a los administradores $^{658}$.

Posteriormente, hay que hacer referencia a la reforma de la Ley Concursal llevada a cabo mediante la Ley 13/2009, de 3 de noviembre. Esta reforma introdujo el art. 8 LC, según el cual sería el juez de lo mercantil el competente para poder conocer las declaraciones de concurso de la sociedad. Y con otra importantísima reforma operada por la Ley 38/2011, de 10 de octubre, se dispuso en el art. 8.7 LC que el juez del concurso sería el competente para conocer las acciones contra los administradores de derecho y los de hecho por los daños causados, antes o después, de la declaración del concurso.

Por su parte, la Ley 38/2011, de 10 de octubre, que reformó la Ley 22/2003 solucionó este problema que había sido una constante preocupación en la coordinación de las responsabilidades societarias y concursales. Así, estableció que los acreedores no podrían reclamar la responsabilidad especial por obligaciones sociales a los administradores si la sociedad había iniciado el procedimiento de declaración de concurso y si la acción era de fecha posterior a la entrada en vigor de esta Ley 38/2011, que fue el 1 de enero de 2012.

${ }^{657}$ Sobre la coordinación de la solicitud de la disolución de la sociedad o la solicitud del concurso también, véase BELTRÁN SÁNCHEZ, E., "La responsabilidad de los administradores por obligaciones sociales", cit., pp. 302-329; y explicando la coordinación de la responsabilidad concursal con el régimen general societario, PARDO PARDO, J. M., El nuevo régimen de responsabilidad, cit., pp. 319-336; ROJO FERNÁNDEZ-RÍO, A. "La reforma del derecho concursal español", en AA.VV., La reforma de la Legislación concursal, cit., pp. 87-149.

${ }^{658}$ Diferenciando entre la coordinación de la responsabilidad concursal y 'la responsabilidad societaria de los administradores, GARCÍA-CRUCES GONZÁLEZ, J. A., "Responsabilidad concursal", en AA. VV., La responsabilidad de los administradores de las sociedades de capital, cit., pp. 355-436. 
En este ámbito se introdujo el art. 50.2 LC, que dispuso que los jueces no debían admitir demandas contra los administradores hasta que no se hubiera declarado el concurso concluso. $\mathrm{Y}$, por otro lado, se introdujo el art. 51 bis LC que permite el archivo de los procedimientos en marcha indicando textualmente que, "declarado el concurso, hasta su conclusión quedarán en suspenso los procedimientos iniciados antes de la declaración del concurso”. Y así fue como la Ley 38/2011 dejaba el análisis de la conducta del administrador para la fase de la calificación del concurso, y solo cuando este hubiese terminado se entablaría la reclamación por las deudas sociales a los administradores, entre ellos al de hecho; otra cosa sería la responsabilidad del administrador de hecho en el ámbito concursal a la que nos referiremos sucintamente por su importancia, pues un estudio más profundo desbordaría el ámbito de este trabajo ${ }^{659}$.

\section{APROXIMACIÓN A LA RESPONSABILIDAD DEL ADMINISTRADOR DE HECHO EN EL ÁMBITO CONCURSAL}

\section{Planteamiento}

La responsabilidad concursal adquiere unos contornos totalmente distintos a los analizados anteriormente, pues la declaración del concurso de la sociedad no supone por sí el nacimiento de responsabilidad para los administradores de derecho ni para los de hecho. Sentada esta premisa, en el art. 164.1 LC se indica que los administradores de la sociedad solo resultarán responsables si el concurso se calificara de culpable, porque se generó o agravó la insolvencia de la sociedad con actuaciones realizadas con dolo o con culpa dentro de los dos años anteriores a la declaración del concurso ${ }^{660}$. De ahí que la responsabilidad en sede concursal no sea de carácter objetivo, como sí lo es la responsabilidad societaria por la omisión del deber de solicitar el concurso prevista en el art. 367 LSC $^{661}$. En concreto, en la

659 Véase MOYA JIMÉNEZ, A., La responsabilidad de los administradores de empresas insolventes, cit., pp. 352-352.

${ }^{660}$ Explicando el nacimiento de la responsabilidad concursal en los administradores de hecho, véase BRENES CORTÉS, J., "La responsabilidad del representante persona física del administrador persona jurídica", cit., pp. 113-121.

${ }^{661}$ Sobre la problemática de responsabilidad concursal en los administradores sociales, véase VERDÚ CAÑETE, M. J., La responsabilidad civil del administrador de sociedades de capital en el concurso de acreedores, Ed. La Ley, Madrid, 2008, pp. 40-41. 
responsabilidad concursal existe un proceso donde el juez con su juicio de valor averigua quién generó o agravó la insolvencia y entonces, si los administradores de derecho o de hecho resultan responsables, ajustará su responsabilidad atendiendo a su participación en los hechos que provocaron la insolvencia ${ }^{662}$.

Así pues, el problema reside en lograr el reproche culpabilístico de la generación de la insolvencia $^{663}$ si el concurso se califica de culposo. Para solucionar este problema el legislador instrumentó la apertura de la sección sexta que viene prevista en el art. 167 LC. Esta pieza es la que versa sobre la calificación del concurso conforme a los trámites contemplados en los arts. 168,169,170,171, pero será en la sentencia de la calificación del concurso, como dispone el art. 172 LC, cuando se declararán las responsabilidades de los administradores de derecho y los de hecho, salvo que el concurso se califique como fortuito $^{664}$.

No obstante, debemos advertir que si administrador de hecho resulta responsable el juez clarificará el motivo por el cual llegó a atribuir tal condición a aquella persona que calificó como administrador de hecho en sus distintas manifestaciones, como la relación de causalidad entre su actuación y el resultado de la generación o la agravación de la insolvencia. Por tanto, nuevamente nos encontramos con el dilema de cómo podría considerarse culpable a un administrador de hecho atendiendo a los elementos de dolo o culpa si este no ostenta las facultades necesarias parar poder cumplir con determinados deberes legales. La razón de esta consideración radica en que el administrador de hecho puede responder por actos externos, pero no por actos internos, al no estar facultado para realizar actos formales que, v. gr.,

\footnotetext{
${ }^{662}$ Introduciendo la intervención del elemento de dolo y de culpa en la responsabilidad concursal de los administradores, ALONSO UREBA, A., "La responsabilidad de los administradores de una sociedad de capital en situación concursal", en AA.VV., Estudios sobre el anteproyecto de la Ley concursal de 2001, cit., pp. 262-313.

${ }^{663}$ Sobre el criterio de la imputación de la responsabilidad concursal, véase, GARCÍA-CRUCES GONZÁLEZ, J. A., "La responsabilidad concursal”, cit., p. 383.

664 Véanse las consideraciones establecidas por GARCÍA-CRUCES GONZÁLEZ J. A., "Declaración de concurso y administradores de la persona jurídica concursada" en AA.VV., Estudios en Homenaje al Prof. Albaladejo, v. I, Murcia, 2004, p. 1969; GARCÍA-CRUCES GONZÁLEZ, J. A., "Problema de la represión de la conducta del deudor común" cit., pp. 248 y ss.
} 
señalamos en los siguientes: solicitar la declaración del concurso de la sociedad o la presentación de las cuentas anuales, o la confección de la contabilidad ${ }^{665}$.

Al respecto, consideramos que habría que atender al caso en concreto que dependerá de multitud de factores como podría ser el tipo de sociedad, es decir, si esta es de grandes dimensiones o una pequeña sociedad y, sobre todo, a las facultades asignadas al administrador de hecho o a la forma de organización que adopte el órgano de administración ${ }^{666}$.

Sin embargo, hay que advertir que el administrador de hecho en sede concursal podría resultar responsable si participó en alguna decisión de la sociedad, siempre que su actuación haya conducido a la generación de la insolvencia y, en cambio, en la responsabilidad societaria para que resulte responsable se requiere que el administrador actúe de forma continuada y estable en la administración de la sociedad. En este sentido, señalar, que en virtud de la reforma de la Ley 38/2011, la LC avanzó en la extensión de la responsabilidad subjetiva del administrador de hecho en sede concursal ${ }^{667}$, pues en su art. 48 ter se estableció que una vez declarado el concurso se decretaría el embargo de bienes y de derechos del administrador de hecho ${ }^{668}$. De ahí, que debamos aludir a la vorágine legislativa en esta sede pues, tras la reforma operada por la Ley 9/2015, en la LC se excluyó a una de las posibles manifestaciones ocultas de administrador de hecho, en concreto, a los acreedores de la sociedad en el art. 93.2.1 LC, con una presunción iuris tamtum si suscribieron un "acuerdo de refinanciación, convenio concursal o acuerdo extrajudicial de pagos por las obligaciones que asuma el deudor en relación con el plan de viabilidad salvo que se probara la existencia de alguna circunstancia que pudiera acreditar su condición".

${ }^{665}$ Para las excepciones de la responsabilidad del administrador de hecho, véase ALONSO UREBA, A., "Administrador de hecho y grupos de sociedades", Otrosí, núm. 12, 2012, p. 25.

${ }^{666}$ En este sentido, véase VERDÚ CAÑETE, Mª J., Responsabilidad civil de los administradores, cit., pp. 212-213.

${ }^{667}$ Sobre la responsabilidad de los administradores tras estas reformas, véanse GARCÍA-CRUCES GONZÁLEZ, J. A., "La responsabilidad concursal", cit., pp. 299-302; QUIJANO GONZÁLEZ, J., "La responsabilidad concursal tras la Ley 38/2011 de reforma de la Ley Concursal", RDCP, núm.18, 2013, explicando las reformas operadas en la Ley Concursal por la Ley 38/2011.

${ }^{668}$ La reforma operada por la Ley 38/2011 la podemos encontrar en la obra de PARDO PARDO, J. M., El nuevo régimen jurídico, cit., 296-297. 
De esta manera se instauró una limitación para la calificación jurídica de administrador de hecho, en tanto que no alcanzarían esta calificación los acreedores que capitalizaron deuda de la sociedad con acuerdos de refinanciación antes de la fecha de la declaración de su concurso $^{669}$. Y, por otro lado, tampoco la alcanzarían las personas que hubieran suscrito un acuerdo de refinanciación conforme a un plan de viabilidad para que esta pudiera salir de su crisis económica, salvo que se acreditara que estas personas ostentaban en la sociedad la condición de un verdadero administrador de hecho ${ }^{670}$.

\section{La responsabilidad concursal. Su especial regulación}

En este apartado vamos a describir la evolución de la responsabilidad concursal sucintamente, comenzando por las modificaciones introducidas por la Ley 38/2011, de 10 de octubre. Esta reforma supuso una batería de preceptos legales, aunque la novedad en relación al administrador de hecho fue el artículo 172 bis LC, ya que se le impuso otra responsabilidad concursal por la cobertura total o parcial del déficit patrimonial del concurso en la medida en que participó en la insolvencia ${ }^{671}$. De ahí que el administrador de hecho podría responder por dos responsabilidades: la primera, la general que se regula en el art. 172 LC y, la segunda, subsidiaria de la primera y prevista por el art. 172 bis $\mathrm{LC}^{672}$.

La primera de las responsabilidades, llamada general, afectará al administrador de hecho cuando la sentencia que calificó el concurso como culpable declare que este con su

${ }^{669}$ En el ámbito subjetivo de la responsabilidad véanse GARCÍA-CRUCES GONZÁLEZ, J. A., "Responsabilidad concursal", cit., pp. 362-367 y pp. 408-409; PARDO PARDO, J. M., EL nuevo régimen, cit., pp. 216-220.

${ }^{670}$ Explicando las actualizaciones sobre el administrador de hecho en materia de refinanciación, véanse SENET MARTÍNEZ, S., "Real Decreto- Ley 1 /2015, de 27 de febrero, de mecanismo de segunda oportunidad, reducción de carga financiera y otras medidas de orden social", Fascículo de actualización de Ley Concursal (Coord. MACÍAS CASTILLO Y JUEGA CUESTA), Ed. Lefévre el Derecho, Madrid, 2015; PARDO PARDO, J. Mª., El nuevo régimen de responsabilidad, cit., pp. 3364.

${ }^{671}$ Explicando los presupuestos de la responsabilidad por déficit patrimonial, véanse RODRÍGUEZ RUÍZ VILLA, D. Y HUERTA VIESCA, M. I.., Responsabilidad de los administradores, cit., pp. 715 y ss.; SACRISTÁN BERGIA, F., "La conclusión del concurso por insuficiencia de masa y sus efectos sobre los administradores societarios", en AA.VV., Estudios sobre órganos de las sociedades de capital, ob. cit., pp. 835-850.

${ }^{672}$ El ámbito subjetivo de la responsabilidad concursal en los administradores de hecho, véase PARDO PARDO, J. $\mathrm{M}^{\mathrm{a}}$., El nuevo régimen de la responsabilidad, cit., pp. 221-269. 
actuación generó o agravó la insolvencia pudiendo ser condenado, como establece el art. 172. 2 LC, a una inhabilitación para administrar bienes por un periodo de dos a quince años, pero atendiendo, en todo caso, a la gravedad de los hechos y a la entidad del perjuicio y, por otro lado, como dispone el art. 172.3 LC, también será condenado a perder el derecho de acreedor contra la masa dirigido a la devolución de bienes o derechos que hubiera obtenido indebidamente, y al de indemnizar por los daños y perjuicios causados.

La segunda responsabilidad, denominada de cobertura por el déficit patrimonial del administrador de hecho, podrá derivar en condena por el importe que resulte de la cobertura de ese déficit patrimonial de forma total o parcial en la medida en que participó en la generación o agravación de la insolvencia del concurso calificado culpable ${ }^{673} \mathrm{y}$, de esta forma, solo se le condenaría a la parte que le corresponda de la cobertura de tal déficit patrimonial.

\subsection{Actuaciones u omisiones desencadenantes de la responsabilidad concursal} general y su aplicación al administrador de hecho

Para declarar a una sociedad en un concurso como culpable, el legislador recogió toda una serie de conductas en el art. 164.2 LC como presunciones iuris et de iure que determinan automáticamente el concurso de la sociedad culpable ${ }^{674}$. Estas conductas u omisiones se contemplan en los sucesivos apartados del precepto. Primero, el incumplimiento del deber de llevar la contabilidad o doble contabilidad, o irregularidades relevantes en la situación patrimonial o financiera. Segundo, irregularidades de documentos en la presentación del concurso o documentos falsos. Tercero, la apertura de la liquidación por incumplimiento de convenio. Cuarto, alzamiento de los bienes o impedimento de embargo. Quinto, salida fraudulenta de bienes en los dos años anteriores a la fecha de la declaración del concurso.

${ }^{673}$ Véanse ALONSO UREBA, A., "La responsabilidad concursal de los administradores de una situación concursal (el art. 172.3 de la Ley Concursal y sus relaciones con las acciones societarias)", cit., p. 564 y ss.; GARCÍA-CRUCES GONZÁLEZ, J. A.," Responsabilidad concursal” cit., pp. 328332.

${ }^{674}$ La responsabilidad concursal y sus especiales presupuestos, véanse GARCÍA-CRUCES GONZALEZ, J. A., "La responsabilidad concursal", en AA.VV., La responsabilidad de los administradores, cit., pp. 362-367; PARDO PARDO, J. M., El nuevo régimen de responsabilidad, cit., pp.145-146. 
Sexto, actos jurídicos para simular patrimonio ficticio antes de la fecha de la declaración del concurso hubiera simulado ${ }^{675}$.

Por su parte, en el art.165 LC se recogen unos comportamientos calificados como presunciones iuris tantum, presumiendo el dolo o la culpa grave en la generación o agravación de la insolvencia, salvo que los administradores de derecho o los de hecho acrediten que actuaron sin dolo o sin culpa. El primero, cuando los administradores no solicitaron el concurso. El segundo, si no colaboraron con el juez. El tercero, si no formularon o depositaron las cuentas anuales, o no las sometieron a auditoria. El cuarto, el negarse a capitalizar créditos o a la emisión de valores o instrumentos convertibles que frustren la refinanciación ${ }^{676}$.

No obstante, el juez para condenar a un administrador de hecho primero tendría que calificarlo como tal dentro de los dos años anteriores a la fecha de la declaración del concurso, tal y como se establece en el art. 161.1 LC, y, segundo, que por su actuación u omisión se hubiera generado o agravado la insolvencia ${ }^{677}$, aunque para el supuesto previsto en el art. 165.4 LC el administrador de hecho o de derecho podría no resultar responsable si tenía causa razonable para poder negarse a la capitalización de la deuda o la emisión de valores o instrumentos convertibles, aunque por su negación se generara o agravara la insolvencia.

${ }^{675}$ Para esta clasificación, véase MACÍAS CASTILLO, A., Y JUEGA CUESTA, R., Ley Concursal Comentada, Ed. El Derecho, Madrid, 2014, pp. 544 y ss.

${ }^{676}$ En definitiva, la generación o la agravación del estado de insolvencia imputable a los administradores, es un supuesto de incumplimiento del referido deber general de diligencia, véase ALONSO UREBA, A., "La responsabilidad concursal de los administradores de una sociedad en situación concursal (el artículo 172.3 del anteproyecto de la ley Concursal y sus relaciones con las acciones societarias)", cit., pp. 304-307. En el mismo sentido, sosteniendo que la calificación culpable tiene lugar cuando la insolvencia deriva de la infracción de los deberes más elementales y que tiene que evitar la producción del estado de insolvencia o su agravamiento, véase GARCÍA-CRUCES GONZÁLEZ, J. A., La calificación del concurso, cit., pp. 22. Señalando la existencia de un deber concreto en la imposición de responsabilidad o la infracción de cualquier deber especifico o de los deberes generales de diligencia y lealtad RONCERO SÁNCHEZ, A., "Naturaleza y caracteres de la responsabilidad concursal de los administradores de sociedades de capital (a propósito de la sentencia de la Sección $15^{\text {a }}$ de la Audiencia provincial de Barcelona de 19 de marzo de 2007)", RDCP, núm. 7, 2007, p. 151. Haciendo referencia a los deberes de lealtad y diligencia en el origen de la responsabilidad concursal, véase VERDÚ CAÑETE, M. J., La responsabilidad del administrador de sociedad de capital en el concurso de acreedores, cit., p.178.

677 En torno a la evolución y finalidad de la responsabilidad concursal, véanse DÍAZ ECHEGARAY, J. L., Presupuestos de la responsabilidad de los administradores concursales, Ed. Aranzadi, Cizur Menor, 2012. pp. 24-32; FERNÁNDEZ DE LA GÁNDARA, L., "La responsabilidad concursal de los administradores de sociedades de capital", en AA.VV., Comentarios a la Ley Concursal, cit, pp. 701-721. 
$\mathrm{Al}$ respecto, consideramos que el administrador de hecho no podría ser calificado como responsable por la falta del depósito de las cuentas anuales o por no someterlas a auditoria, ni por no llevar la contabilidad o por no solicitar el concurso de la sociedad, porque el administrador de hecho no ostenta la legitimación formal para su presentación. No obstante, el incumplimiento de estos deberes legales se convirtió en una cuestión controvertida, pues un sector doctrinal consideraba que el simple incumplimiento de no solicitar el concurso no era causa suficiente para considerar a los administradores responsables, ya que hacía falta que se hubiera generado o agravado la insolvencia por su omisión ${ }^{678}$. Y, otro sector consideraba que si el legislador había previsto que por este comportamiento se declarara el concurso culpable ya no cabía añadir nada más ${ }^{679}$.

\subsection{La naturaleza de la responsabilidad por déficit patrimonial}

Con la última reforma operada en la LC por el RDL 4/2014, de 7 de marzo, se determinó que la naturaleza jurídica de la responsabilidad por el déficit patrimonial era indemnizatoria o causal porque así se incluyó en el art. 172 bis LC, al indicar que los administradores de derecho o los de hecho solo iban a responder "en la medida que la conducta que ha determinado la calificación culpable haya generado o agravado la insolvencia" ${ }^{280}$. No obstante, su naturaleza había sido objeto de dos grandes posturas contradictorias; un sector de la doctrina consideraba que esta era de corte indemnizatorio, resarcitorio o por daños ${ }^{681}$, mientras que otro lo estimaba de naturaleza sancionadora ${ }^{682}$.

${ }^{678}$ Véanse GARCÍA-CRUCES GONZÁLEZ, J. A., "El problema de la represión de la conducta del deudor común", cit., pp. 256-304; BELTRÁN SÁNCHEZ, E, "En torno a la naturaleza de la responsabilidad concursal comentario a la sentencia de la Sección $28^{\text {a }}$ de la Audiencia Provincial de Madrid de 5 de febrero de 2008". Artículo integrante del Proyecto de Investigación "La Reforma del Derecho concursal español. Antecedentes y objetivos", $A D C$, núm.14, 2008.

${ }^{679}$ En este sentido, véanse ALCOVER GARAU, G., "Aproximación de la naturaleza jurídica de la responsabilidad concursal de los administradores de las sociedades de capital", $R D C P$, núm. 7, 2007, pp. 91-108; MACHADO PLAZAS, J., El concurso de los acreedores culpable. Calificación y responsabilidad concursal, Ed. Thomson Cívitas, Navarra, 2006.

${ }^{680}$ Sobre la reforma concursal operada por el RDL 4/2014, véase PARDO PARDO, J. M., El nuevo régimen e la responsabilidad, cit., pp. 298-302.

${ }^{681}$ En torno a estas consideraciones, véanse a ALONSO UREBA, A., "La responsabilidad concursal de los administradores de una sociedad de capital en situación concursal (el art. 172.3 de la LC y sus relaciones con las acciones societarias de responsabilidad)", cit., pp. 544-545; BLASCO GASCÓ, F., Responsabilidad Concursal y embargo de los bienes de los acreedores, Ed. Tirant lo Blanch, Valencia, 2007, pp. .45 y ss.; GARCÍA-CRUCES GONZÁLEZ, J. A., Las claves de la Ley concursal, 
También la posición de nuestra jurisprudencia era contradictoria. Un sector contemplaba su carácter indemnizatorio por la necesidad de que existiera un acto antijurídico y culpable con su correspondiente relación de causalidad entre ese acto y el daño producido; en este sentido la SAP de Barcelona de 21 de mayo de 2012 (RJ 154/2012) ${ }^{683}$. Otro sector, en sentido contrario, la consideraba de carácter sancionador porque solo se necesitaba una imputación subjetiva al administrador de derecho o de hecho en la calificación del concurso culpable, tal y como se recoge en la SAP de Barcelona de 10 de septiembre de 2010 (RJ 203/ $2010)^{684}$. De ahí, que ya no era necesario otro enlace causal que el que había resultado de la calificación del concurso como culpable, dadas las conductas de los administradores de hecho o de derecho; en este sentido SAP de Madrid de 21 de mayo de 2012 de Barcelona (RJ $154 / 2012)^{685}$.

No obstante, ambas corrientes olvidaron añadir las circunstancias que concurrirían en el caso concreto, pues la base de esta responsabilidad, prevista en el art. 172 bis LC, no tiene como única finalidad el resarcimiento a los acreedores del concurso, ya que el legislador quiso además instaurar un régimen normativo en la responsabilidad por el déficit con el fin de poder "sancionar" a los administradores de derecho o de hecho que generaron o agravaron la

Ed. Aranzadi, Cizur Menor, 2005, pp. 545 y ss. También, se ha venido manifestado que el régimen legal en materia de responsabilidad concursal, en particular, en los aspectos relativos a sus presupuestos alcance y exoneración, permiten que estamos en el ámbito más general de la responsabilidad civil subjetiva o por daños de los administradores sociales, véase VERDÚ CAÑETE, La responsabilidad civil del administrador de sociedad de capital en el concurso de acreedores, cit., pp. 79 y ss.

${ }^{682}$ El significado punitivo de la responsabilidad concursal y destacando su caracterización como una responsabilidad-sanción y culposa, véanse BELLO MARTÍN-CRESPO, M"a. P., "Responsabilidad de los administradores de sociedades de capital y Ley concursal", en Estudios sobre la Ley Concursal. Libro Homenaje a Manuel Olivencia, II, Madrid, 2005, pp. 1679 y ss.; GUERRERO LEBRÓN, Mª. J., Y GÓMEZ PORRÚA, J. M., "La responsabilidad de los administradores de las sociedades de capital en situación concursal", cit., pp.1965-1988; FERNÁNDEZ DE LA GÁNDARA, L., "La responsabilidad concursal de los administradores de sociedades de capital", en AA.VV., Comentarios a la Ley Concursal, cit., p. 711; LLEBOT MAJÓ, J. O., "La responsabilidad concursal de los administradores, en $R G D$, núm. 657,1999, pp. 179-189; MARÍN DE LA BÁRCENA GARCÍA MARTÍN. F., "Deberes y responsabilidad de los administradores ante la insolvencia de las sociedades de capital”, RdS, núm. 24, 2000, pp. 91 y ss.; RODRÍGUEZ RUÍZ VILLA, D. Y HUERTA VIESCA, $\mathrm{M}^{\mathrm{a}}$., Responsabilidad de los administradores de las sociedades de capital, cit., pp., 675-713; VICENT CHULIÁ, F., "La responsabilidad de los administradores en el Concurso", cit., pp. 15 y ss.

${ }^{683}$ En este sentido, véase SAP de Barcelona de 21 de mayo de 2012 (RJ 154/2012) que sostiene el criterio por daño en la responsabilidad de los administradores por déficit.

${ }^{684}$ En este sentido SAP de Barcelona de 10 de septiembre de 2010 (RJ 203/ 2010).

${ }^{685}$ En este sentido la SAP de Madrid de 21 de mayo de 2012 de Barcelona (RJ 154/2012) sostiene el criterio por daño en la responsabilidad de los administradores por déficit. 
insolvencia por sus actuaciones con dolo o culpa grave en el ejercicio de las obligaciones inherentes al desempeño del $\operatorname{cargo}{ }^{686}$.

Por su parte, la jurisprudencia consolidó en STS de 6 de octubre de 2011 (RJ 644/2011) la opinión de que, para poder interpretar el precepto que recogía la responsabilidad concursal, había que entender que esta no era solo una consecuencia del concurso culpable, sino que además se necesitaba de una justificación añadida para poder condenar a los administradores de hecho o derecho a satisfacer todo o parte de los créditos que los acreedores no pudieron percibir en la liquidación de la masa activa del concurso ${ }^{687}$.

Sin embargo, las posturas de la doctrina continuaban estando polarizadas, pues se suscitaba la duda de su naturaleza, y esta incertidumbre se mantuvo durante largo tiempo con estas posturas alternativas sin que pareciera posible que alguna se alzara como la postura predominante ${ }^{688}$. La razón estribaba en que la jurisprudencia mayor no establecía un criterio claro, aunque en un principio parecía que se inclinaba por una responsabilidad indemnizatoria por el daño sufrido a los acreedores ${ }^{689}$. No obstante, la jurisprudencia menor señalaba que no se llegaba a concluir que fuera así, pues parecía que era una responsabilidad objetiva donde el juez tenía que ampliar su discrecionalidad para fijar el importe cuantitativo que los administradores de derecho o de hecho tendrían que satisfacer a los acreedores ${ }^{690}$. Sin embargo, esta responsabilidad se trataba más bien de una responsabilidad por daños, porque hay que tener en cuenta elementos subjetivos y objetivos del comportamiento de los administradores de derecho, y sobre todo del administrador de hecho, que como ya es sabido no ostenta la legitimación formal para imputársele las actuaciones u omisiones previstas en los arts. 164 y 165 LC, que son los que determinarán el concurso como culpable ${ }^{691}$.

${ }^{686}$ En torno es esta materia también se pronunciaba sobre la naturaleza de esta responsabilidad con una imputación objetiva, véase MOYA YODI, J. Y RUÍZ RUBIO, M. C., "La naturaleza jurídica especial de la responsabilidad por el déficit a la luz de los criterios de imputación objetiva contenidos en el artículo 172 bis de la Ley concursal”, Aranzadi Insignis, núm. 8. 2012.

${ }^{687}$ En este sentido, véase STS de 6 de octubre de 2011 (RJ 644/2011).

688 En relación a esta consideración VILLANUEVA GARCÍA-POMAREDA, B., "La responsabilidad concursal de los administradores sociales", CMS, julio, 2012.

${ }^{689}$ En este sentido, véase entre otras, STS de 23 de febrero de 2011 (RJ 2475/ 2011).

${ }^{690}$ También, véase en este sentido SAP de Barcelona de 23 de abril de 2012(JUR 176693/ 2012).

${ }^{691}$ Véase SAP de Barcelona de 19 de marzo 2007 (RJ 653/2007). 


\subsection{La responsabilidad del administrador de hecho por déficit patrimonial. Sus} presupuestos

La responsabilidad por el déficit patrimonial $^{692}$ consiste en una especial responsabilidad por su carácter subsidiario, pues solo nace por el incumplimiento del convenio o por la apertura de la liquidación del concurso calificado culpable según dispone el art. 172.1 bis LC. No obstante, hay que advertir que los administradores de derecho y los administradores de hecho no serán condenados, aunque existiera déficit patrimonial tal y como previene el precepto cuando dice "en la medida que la conducta que ha determinado la calificación culpable haya generado o agravado la insolvencia"693. Así que, en orden a conducir la aplicación práctica de lo que viene dispuesto en el art. 172 bis LC, en este epígrafe estudiaremos los presupuestos de la responsabilidad por déficit patrimonial ${ }^{694}$.

Los requisitos necesarios para que nazca la responsabilidad por déficit patrimonial en los administradores de derecho y en los de hecho son: Primero, que la calificación del concurso sea culpable, ya sea por la apertura de la fase de liquidación del concurso o por incumplimiento del convenio de la sociedad concursada. Segundo, que la generación o la insolvencia traiga su causa de actuaciones realizadas con dolo o culpa en los dos años anteriores a la declaración del concurso. Y, por último, un déficit patrimonial, es decir, el quamtum indemnizatorio. Este quantum fue introducido por el RDL 4/2014, de 7 de marzo, en la LC que, posteriormente, fue conformado por la Ley 17/2014, de 30 de septiembre ${ }^{695}$. Es decir, será la cobertura total o parcial del déficit patrimonial que resulte de la masa activa ${ }^{696}$. Este quantum será fijado en función de la participación de cada uno de ellos en la generación o agravación de la insolvencia, de modo que los afectados, ya sea el administrador de hecho o

${ }^{692}$ Ver por todos RODRÍGUEZ RUÍZ VILLA, D. Y HUERTA VIESCA, M‥, La responsabilidad de los administradores de las sociedades de capital en crisis, cit., p. 721

${ }^{693}$ Sobre el marco general del concurso de acreedores, véase MARINA GARCÍA-TUÑON, A., "Junta general y concurso de acreedores" en AA.VV., Estudios sobre órganos de las sociedades de capital, cit., pp. 225-264.

${ }^{694}$ Véase MOYA BALLESTER, J., La responsabilidad de los administradores de sociedades en situaciones de crisis, cit., pp. 26 y ss.

${ }^{695} \mathrm{Al}$ respecto, en relación a la naturaleza de la responsabilidad concursal MACÍAS CASTILLO, A. Y JUEGA CUESTA R., Ley concursal comentada, cit., pp. 543-551.

${ }^{696}$ Véase ALONSO UREBA, A., La responsabilidad, cit., p. 533. 
el de derecho, tendrán que satisfacer a los acreedores de la masa del concurso culpable el importe pendiente de los créditos no percibidos ${ }^{697}$.

No obstante, mediante la reforma operada por la Ley 9/2015 en la LC, en el art. 172 bis LC se estableció que se necesita además "una justificación adicional”. Es decir, que el juez condenará atendiendo a las circunstancias que concurren en el concreto caso. Así que, en el caso particular de la responsabilidad por el déficit patrimonial, la Ley señala que hace falta concretar en qué medida los administradores de derecho o los de hecho participaron en la generación o agravación de la insolvencia ${ }^{698}$.

De modo que, podría ocurrir que no se condene a los administradores de derecho ni a los de hecho, aunque exista déficit patrimonial ${ }^{699}$, debido a que no actuaron con el dolo necesario o con culpa grave en la generación o agravación de la insolvencia. En concreto, si los administradores tuvieron que asumir riesgos excesivos para adoptar sus decisiones o cuando los administradores favorecieron a los acreedores o, incluso, si los administradores no pudieron cumplir con los deberes que exige en la contabilidad ${ }^{700}$.

Una vez descritos de manera sumaria los requisitos de responsabilidad concursal por déficit, resulta necesario aludir a una cuestión de extraordinaria importancia, que es la relativa a la necesidad de justificación añadida para poder exigir esta responsabilidad por déficit. A estos efectos, nuestros tribunales de forma paulatina fueron abordando cómo la responsabilidad por déficit se extendería a los administradores de hecho y a los

${ }^{697}$ Explicando la fijación de la responsabilidad por la cobertura del déficit patrimonial, véase GARCÍA-CRUCES GONZÁLEZ, J. A., La calificación del concurso, cit., p. 171.

${ }^{698}$ Explicando los requisitos de la declaración del concurso culpable por la actuación de un administrador de hecho, véase PORFIRIO CARPIO, L. J., "Administradores de hecho y concurso", cit., pp. 30.

${ }^{699}$ Sobre la calificación de la responsabilidad concursal y sus excepciones, véase GARCÍACRUCES GONZÁLEZ, J. A., "La responsabilidad concursal”, cit., pp. 387-397.

${ }^{700}$ Explicando estos casos de excepción de la responsabilidad de los administradores, véanse MARÍN DE LA BÁRCENA GARCÍA MARTÍN, "Responsabilidad concursal", $A D C$, núm. 28, 2013; QUIJANO GONZÁLEZ, J., "La responsabilidad concursal tras la Ley 38/2011", RDCP, núm. 18, 2003, p. 8. 
administradores de derecho y, para ello, aludían a que era necesario la existencia de una concreta circunstancia, esto es, la concurrencia de una justificación añadida ${ }^{701}$.

En resumen, el juez tenía que imponer la condena por déficit tras una valoración conforme al caso concreto, a tenor de los criterios normativos y de distintos elementos subjetivos y objetivos. Estos elementos se concretaban con aquellas circunstancias que concurrían en el comportamiento de los afectados para poder fundamentar el reproche culpabilístico que es necesario para condenar por el déficit patrimonial. Es decir, la responsabilidad no se determinará por la existencia de un déficit patrimonial, pues lo que se sancionaba era la conducta que había causado el daño y que tenía su manifestación en la insolvencia y en el prejuicio de los acreedores que no pueden hacer efectivo el cobro de sus créditos.

De ahí que el juzgador valorando el caso concreto apreciaría dos supuestos: el primero, si hubo incumplimiento por parte de los administradores de derecho o de hecho de los deberes de diligencia y lealtad en una situación económica crítica en la sociedad, y, el segundo, si los administradores de derecho o de hecho realizaron operaciones que entrañaban alto riesgo donde difícilmente se quebranta el deber general de diligencia, aunque el resultado de estas operaciones hubieran generado o agravado la insolvencia provocando la calificación culpable en un posterior concurso ${ }^{702}$.

Por tanto, la determinación de la responsabilidad por déficit patrimonial se deberá de concretar atendiendo a unos criterios, muy concretos ${ }^{703}$. El primero, denominado criterio de modulación, que es el relativo al grado de participación en el resultado dañoso, es decir, un nexo causal entre la actuación y el resultado dañoso a los acreedores ${ }^{704}$.

El segundo, el riesgo del negocio, que puede o no contribuir en la agravación de la insolvencia. En este sentido, nuestra jurisprudencia sostiene, en STS de 26 de abril de 2012

${ }^{701}$ En concreto, la Sala $1^{\mathrm{a}}$ del Tribunal Supremo, ha ido construyendo la doctrina jurisprudencial para completar la Ley Concursal, véase STS de 26 de abril de 2012 (RJ 161790/ 2012).

702 Véase MONTOYA BALLETER, J., La responsabilidad, cit., pp. 297 y ss.

703 Explicando la dureza de la sanción de cobertura del déficit, véase ALCOVER GARAU, G., "Consideraciones generales sobre la alternativa de la reforma propuesta de derecho concursal", cit., pp. 486-4888.

${ }^{704}$ Véase ALCOVER GARAU, G., “Aproximación a la naturaleza jurídica de la responsabilidad de los administradores de las sociedades de capital”, cit., pp. 91-108. 
(RJ 161790/ 2012), que la concreción de esta responsabilidad deberá realizarse utilizando los parámetros de gravedad de la conducta en función de las presunciones previstas en los arts. 164 y 165 LC y de la participación que se haya realizado en esas conductas ${ }^{705}$.

Por consiguiente, el problema que subyace en esta responsabilidad es que para condenar al administrador de hecho hace falta una justificación añadida, ya que no se trata de una responsabilidad absolutamente sancionadora u objetiva como la establecida en el art. 367 LSC, sino que es más bien es una responsabilidad objetivada ${ }^{706}$ donde la participación del administrador de hecho en la calificación del concurso como culpable constituye un presupuesto imprescindible para que este resulte responsable por la responsabilidad por el déficit $^{707}$.

Así que, consideramos que la prueba de la actuación del administrador de hecho en la calificación del concurso como culpable, en su manifestación externa, resultaría fácil, pues solo bastaría que se probara su participación. Sin embargo, su responsabilidad sería problemática porque las actuaciones u omisiones calificadas como culpables corresponden al administrador formal. En cambio, con el oculto, aunque la prueba de su actuación resultaría más difícil por su manera de actuar ocultamente, sí que resultaría culpable por haber dictado u omitido las órdenes al administrador formal, como podrían ser la forma de llevar la contabilidad, la omisión de solicitar el concurso o un alzamiento de bienes en los dos años anteriores a la declaración del concurso, o aquellos actos jurídicos para simular patrimonio ficticio; en definitiva, cada una de las conductas previstas en el art. 164.2 LC $^{708}$.

${ }^{705}$ En relación la Sala $1^{\text {a }}$ del Tribunal Supremo, han ido construyendo la doctrina jurisprudencial para completar la Ley Concursal, así de este modo, STS de 26 de abril de 2012 (RJ 161790/ 2012).

${ }^{706}$ Explicando los presupuestos de la responsabilidad por déficit GARCÍA-CRUCES GONZÁLEZ, J. A., "Acumulación y coordinación de acciones de responsabilidad de los administradores de un apersona jurídica en concurso (sobre inserción de la llamada responsabilidad concursal en el régimen general de responsabilidad de administradores", $A C$, núm. 18, 2004; www.westlaw.es.

707 Para mayor estudio, véase PASTOR SEMPERE, M. C., "Responsabilidad de los administradores", en AA.VV., Archivo Commenda de jurisprudencia societaria (Dir. EMBID IRUJO, J. M.,), núm. 2011-2012, pp. 171-194.

${ }^{708}$ En este sentido, recordemos LATORRE CHINER, N., El administrador de hecho, cit., pp. 6165; HERNANDO CEBRIÁ, L., "Presupuestos del deber de lealtad", cit., pp. 152-153. 


\section{CONCLUSIONES}


PRIMERA. La evolución de la configuración jurídica del administrador de hecho culminó en nuestro país con la Ley 31/2014, para la mejora del gobierno corporativo de las sociedades de capital. Esta Ley terminó con la controvertida polémica sobre su adecuado encuadramiento en el ámbito societario al definirlo legalmente, por vez primera, en el art. 236.3 LSC. En concreto, en este precepto se establece que “... tendrá la consideración de administrador de hecho tanto la persona, que en la realidad del tráfico desempeña sin título, con título, con título nulo o extinguido, o con otro título, las funciones propias de administrador, como en su caso, aquella bajo cuyas instrucciones actúen los administradores de la sociedad”. En realidad, se contemplan distintos perfiles que reflejan una gran diversidad de posibles administradores de hecho al vincular su concepto al modo de actuar en la sociedad de estos sujetos que realizan, sin serlo, las funciones propias de un administrador.

Esta amplitud conceptual permite distinguir dos grandes categorías de administrador de hecho. La primera, el denominado por la doctrina como administrador de hecho notorio, que es aquel que actúa en el tráfico realizando las funciones de administrador, pero sin título, con título nulo o extinguido con un nombramiento implícito por parte de la sociedad.

La segunda categoría es aquella que se integra por el llamado administrador de hecho oculto en la que podemos distinguir, a su vez, dos tipos. El primero se integra por aquella persona que actúa bajo la apariencia de otro título y, el segundo, es el que realiza funciones de administración impartiendo instrucciones a los administradores ocultando su presencia con una intención manifiesta de que no se sepa su identidad.

En definitiva, La LSC define al administrador de hecho en el sentido más amplio posible para prevenir el fraude de aquellas personas que quieren evitar la aplicación de las normas imperativas y la responsabilidad de los administradores societarios. De ahí la justificación de los diversos perfiles de administradores de hecho descritos en el art. 236.3 LSC.

En resumen, la definición legal equipara automáticamente al administrador de hecho como administrador de derecho porque, por su modo de actuar, deberá cumplir con los deberes propios de estos cargos y someterse a su especial régimen de responsabilidad. 
No obstante, debemos partir de dos premisas. La primera, que el concepto de administrador de hecho debe ser entendido en sentido restringido, porque la realidad y la apariencia jurídica normalmente coinciden, no debiendo extenderse indiscriminadamente la responsabilidad de los administradores a cualquier sujeto que realizara alguna actuación propia de estos y, la segunda, que para poder identificar a un administrador de hecho debemos atender a las particulares circunstancias que concurren en cada supuesto concreto.

SEGUNDA. En la definición legal del administrador de hecho no se indican las pautas concretas de su actuación, sino que se limita a señalar que consistirá en ejercer aquellas funciones propias de los administradores en el tráfico mercantil. En consecuencia, para poder identificar a un administrador de hecho dentro de la sociedad, ya sea cuando se manifiesta externamente frente a terceros o cuando actúa de forma oculta, tendremos que recurrir a los criterios que se han venido conformando por nuestra doctrina y jurisprudencia. En realidad, estas son las que han ido, paulatina y progresivamente, elaborando las pautas de actuación que nos permiten detectar la presencia del administrador de hecho.

En concreto, que este deberá de actuar ejerciendo la dirección efectiva de la sociedad en aquellas materias reservadas a los administradores con el consentimiento de la sociedad. Además, el administrador de hecho deberá ejercer labores de administración con profesionalidad adecuada, con presencia efectiva permanente y con protagonismo de dirección, hasta tal punto que se pueda deducir ciertamente que ostenta las facultades de decisión y de gestión, sin subordinación al órgano de administración, es decir, que la persona que alcance esta calificación jurídica deberá realizar actuaciones efectivas de gestión con autonomía, de modo que impliquen el ejercicio efectivo de un poder soberano en la sociedad.

Las razones que justifican estas afirmaciones estriban en que no se puede aplicar indiscriminadamente la responsabilidad de los administradores a aquellas personas que simplemente interfirieron en el mero ejercicio de determinadas funciones que son las propias y específicas de un administrador societario.

En definitiva, el elemento esencial que define a un administrador de hecho será que actúe con autonomía, de tal forma que pueda razonarse y entenderse que viene ejerciendo las 
funciones de gestión y gobierno en la práctica, y que la sociedad viene aceptando y vinculándose con sus actos.

TERCERA. La problemática que presenta la definición del administrador de hecho versa, principalmente, en resolver qué personas físicas o jurídicas pueden integrarse en los perfiles que dibuja la LSC, con especial referencia a su manifestación oculta, pues su definición legal se limita a dibujar un perfil funcional y no formal, configurándolo como un "hecho"; hecho que será necesario probar porque solo merecerán esta calificación los que desempeñen funciones propias de administración.

Por tanto, para determinar si resulta procedente extender la responsabilidad a las diversas manifestaciones que presenta el administrador de hecho tras su estudio, consideramos que, si bien disponemos de la cobertura legal para poder responsabilizarlo en cualquiera de sus manifestaciones, el problema reside en su demostración.

Así, en primer lugar, deberíamos demostrar su actuación oculta cuando actúa bajo la apariencia de un título societario, recurriendo para ello al examen de los indicios. Estos nos permitirán poder presumir que esa persona, por su actuación, es el administrador de hecho que actúa bajo el amparo de un cargo societario.

En segundo lugar, cuando el administrador de hecho se presente en la sociedad administrando ocultamente debe probarse que los propios administradores de la sociedad se encuentran dirigidos por él. Este fin se conseguirá demostrando que los administradores formales no quieren ejercer su criterio o juicio para administrar la sociedad, pues, única y sistemáticamente, actúan conforme a las instrucciones dictadas por el administrador de hecho oculto.

En el resto de manifestaciones del concepto de administrador de hecho, distintas de la del administrador oculto, solo se definen por su modo de actuar, simplemente como un hecho, y, por ello, se necesitará también la correspondiente prueba.

Tras el análisis comparativo de distintas figuras que han llegado a inducir a confusión encuadrándolas, en ocasiones, como administradores de hecho, somos partidarios en este 
ámbito del deslinde a priori de nuestra figura con distintas realidades que se presentan en el ámbito societario como son, entre otros, el director general, el apoderado general o los accionistas mayoritarios. De este modo, solo cuando alguno de ellos pueda demostrarse que actúa como un auténtico administrador de hecho, deberá responder como un administrador formal.

Mención especial merecen en este ámbito los grupos de sociedades. Así, debe partirse de la base de que no pueden integrarse en el concepto de administrador de hecho porque el elemento de coordinación unitaria o de "unidad de dirección" venga ejerciéndose por la sociedad matriz como elemento esencial para la dirección del grupo. No obstante, tampoco hay que excluirlos como posibles administradores de hecho cuando concurran las circunstancias necesarias para que la sociedad matriz pudiera ser calificada como tal cuando ejercitara actuaciones reiteradas y no esporádicas en la actividad gestora de las filiales, y los administradores de estas obedecieran decisiones de carácter orgánico impartidas por la matriz.

En definitiva, para averiguar la identidad del administrador de hecho y sus posibilidades de actuación concluimos que solo tenemos una respuesta, que tendremos que descubrirlo mediante indicios, y siempre dentro de un contexto determinado.

La jurisprudencia ha venido señalando qué clase de indicios son los necesarios para determinar que existe un administrador de hecho actuando en la sociedad. Tras su análisis pueden destacarse como los más relevantes los siguientes: que la persona se encuentre investida de un poder general para poder actuar y gestionar la sociedad; que exista vinculación familiar entre el administrador de hecho y el de derecho si se trata de sociedades familiares; que actúe bajo la apariencia de un simple apoderado; que se trate de un socio mayoritario o que ocupe algún cargo societario, siempre que administren de hecho.

Mención singular y problemática como indicio merece la detentación de un poder de representación muy amplio que englobe todas las facultades que sean necesarias para poder administrar la sociedad, es decir, que sea suficiente para poder representar a la sociedad y que con ese poder el administrador de hecho actúe realizando toda una serie de actos que serán reveladores de que su autor es un auténtico administrador, porque viene sustituyendo a los administradores de la sociedad o porque ejerce sobre ellos una influencia decisiva. Consideramos que el poder de representación es la base para averiguar si, bajo la apariencia 
de un simple apoderado general o factor mercantil, se puede esconder un auténtico administrador de hecho que dirige a la sociedad cuando disponga de poderes o facultades que le permiten situarse en una posición y en unas condiciones predilectas para poder llevar a cabo todas las conductas típicas de un administrador y poder cumplir con los deberes de los administradores.

No obstante, hay que advertir que si bien sería necesario ostentar un poder de representación y de actuación que otorgue amplias facultades para poder determinar si nos encontramos ante un administrador de hecho, no es totalmente indicativo que un apoderado $\mathrm{u}$ otra figura societaria ostente amplios poderes de representación, debiendo de atender a las circunstancias del caso concreto.

CUARTA. La equiparación del administrador de hecho con el de derecho en el art. 236.3 LSC supone que las personas que se conceptúen como tal deben cumplir con los deberes de los administradores. Sin embargo, se olvidó determinar cómo podrán cumplirlos por su condición de ser simplemente un hecho.

En el segundo capítulo, tras el estudio de los deberes de los administradores, se observa que antes de exigir el cumplimiento de los deberes al administrador de hecho debemos dilucidar en qué medida este podrá ejercerlos si carece de legitimación formal para cumplirlos, ya que sus posibilidades de actuación se encontrarán supeditadas en gran medida por el tipo de sociedad y por el modelo de administración que esta haya adoptado. A este respecto debemos resaltar que la presencia del administrador de hecho se advierte más difícil en el tipo de las sociedades cotizadas, con base en que en estas su órgano de administración se encuentra constreñido, tanto por las normas reguladoras del mercado de valores como por los sistemas de autorregulación establecidos en sus reglamentos de régimen interno que incluyen las recomendaciones de los CBG. No obstante, si estimamos el caso particular de un alto ejecutivo en estas grandes empresas, podría considerarse como un administrador de hecho si existe una clara evidencia de que este ejecutivo actúa como tal de modo oculto, es decir, cuando sus instrucciones son asumidas por el órgano de administración sistemáticamente.

Por tanto, sobre la base de que el administrador de hecho podría actuar en función del modelo de administración que haya adoptado la sociedad, consideramos que podría cumplir con los deberes de los administradores en las SA cerradas y SRL de pequeñas dimensiones 
con administrador único donde la atribución de esta función la suele ostentar un socio mayoritario.

QUINTA. Respecto al ejercicio del deber de diligencia, recordar que viene predeterminado por las circunstancias que concurren en el momento de la decisión del administrador y de los medios de que disponga. Además, el art. 236.1 LSC concreta su cumplimiento en función de la naturaleza del cargo y de las funciones atribuidas a cada administrador y, por ello, consideramos que no se puede exigir su ejercicio al administrador de hecho con la misma intensidad que al de derecho, fundamentalmente, porque el primero es un hecho y no tiene designadas funciones concretas para administrar, ni se conoce cuál es la naturaleza del cargo que se le ha atribuido para realizar las funciones de administración.

Por su parte, para el concreto ejercicio del deber de información, el administrador de hecho tiene que haberse informado previamente antes de adoptar una decisión adecuada y, si no se encuentra facultado por la sociedad para recabar esta información, no podrá cumplir con este deber, pues no podrá conocer lo que está sucediendo en la sociedad para tomar las decisiones de forma autónoma. De este modo, el administrador de hecho cumpliría con su deber de diligencia cuando adopte sus decisiones en función de las posibilidades que tuvo para informarse, ya que si carece de las facultades necesarias no podrá cumplir ni tampoco se le podrá exigir responsabilidad, pues no tiene las mismas posibilidades de actuación que ostentan los administradores para actuar.

Por el contrario, para el cumplimiento del deber de lealtad, por ser más objetivo, por su carácter imperativo y por ser un deber de resultado, somos partidarios de que al administrador de hecho se le exija, evitando, al tiempo, situaciones de conflictos de intereses. Además, el cumplimiento de estos deberes deberá extenderse a aquellas personas que se vinculen con él en cualquiera de sus manifestaciones.

Por tanto, para poder cumplir los deberes que le son propios resulta indispensable analizar previamente las posibilidades que tenía para actuar, recurriendo, fundamentalmente, a las clases de facultades que el administrador de hecho ostentara cuando actuara bajo el amparo de un título societario. A este respecto, nos encontramos con la problemática de que la esencia de este tipo de administrador es precisamente estar oculto y, además, cuando actúa de una forma notoria lo hace sin estar revestido de autoridad. 
En cuanto a la extensión de los deberes de los administradores que les son propios al de hecho consideramos, tras su estudio, que debe distinguirse en función de qué modalidad revista. Así, tal extensión solo sería factible cuando el administrador de hecho actuara en la sombra porque, en este caso particular, es cuando los administradores formales realizan sus funciones de administración, pero siguiendo de forma sistemática las instrucciones de aquel. Por el contrario, dicha extensión no podrá predicarse del administrador de hecho que actúa en la sociedad bajo la apariencia de cualquier título, aunque venga realizando funciones propias de los administradores, porque estos no fueron designados por la sociedad para poder realizar las funciones de administración.

SEXTA. Con relación al cumplimiento de los deberes legales, el administrador de hecho no puede responder de no hacer algo cuando realmente no está capacitado legalmente para realizarlo. Supuesto singular a destacar es cuando conociera de la insolvencia de la sociedad. En este caso, deberá responder por las deudas sociales por el incumplimiento de las obligaciones legales establecidas en el art. 363 LSC con los presupuestos establecidos en el art. 367 LSC, porque continúa, de forma negligente, con la actividad social agravando su estado de insolvencia si se demostrara que el administrador de hecho tiene el control y el poder de dirección en la sociedad a través de la toma de sus decisiones para conseguir el mejor interés social.

En consecuencia, creemos que la naturaleza sancionadora que viene prevista en el art. 367 LSC solo debe ceñirse a quienes legalmente son administradores, salvo que existiera un administrador de hecho que por su modo de actuar dirige la sociedad e incumple con los deberes legales de disolver la sociedad cuando concurren las causas legales.

SÉPTIMA. La extensión de la responsabilidad al administrador de hecho culmina con la aplicación de los presupuestos de la responsabilidad general de los administradores previstos en el art. 236 LSC. Sin embargo, para poder determinar cuándo el administrador de hecho puede resultar responsable habrá que tener presente qué posibilidades reales de actuación tuvo para cumplir con las obligaciones que comprenden los deberes de los administradores.

De este modo, consideramos que a los diferentes tipos de administradores de hecho no se les puede imponer el mismo nivel de exigencia que a los administradores formales ya que 
por ser un hecho no están dotados de funciones específicas, y por esta razón su responsabilidad variará atendiendo a sus posibilidades de actuación para cumplir las obligaciones de los administradores en el caso enjuiciado.

En definitiva, deben analizarse los presupuestos de las distintas clases de responsabilidad que son exigibles al administrador de hecho y cuál sería el nivel de exigencia aplicable según las posibilidades que tuvo para ejercer sus competencias o facultades.

Por tanto, el elemento definitorio para exigir responsabilidad al administrador de hecho viene determinado en su propia definición, pues los deberes no se definen únicamente por lo que son en sí mismos sino por a quiénes le pueden ser exigibles, es decir, la responsabilidad resultaría aplicable simplemente a aquellas personas físicas o jurídicas que ejerzan las funciones propias de los administradores en la sociedad.

Así, el administrador de hecho deberá resarcir del daño causado siempre y cuando en su actuación haya concurrido el nivel de exigencia necesario para ser responsables, es decir, el establecido en el art. 236.1 LSC en cuya virtud todos los administradores societarios responderán si los actos han sido realizados con los elementos intencionales del dolo o de la culpa.

De ahí, que no podremos determinar el nivel de exigencia del administrador de hecho en función de las funciones atribuidas, porque simplemente es un hecho y como tal habrá de probar en qué medida actúo y qué posibilidades tuvo para poder cumplir con los deberes de los administradores; por ello, concluimos que solo se podrá lograr exigir responsabilidad al administrador de hecho oculto, ya que este debería haber dictado la orden oportuna a los administradores para que no se produjera el daño por el incumplimiento de sus deberes.

Por todo lo expuesto, hubiera sido preferible establecer un régimen jurídico específico que regulara la responsabilidad del administrador de hecho, de tal forma que se concretara cuáles son las disposiciones normativas y los deberes legales a los que se encuentra obligado, pues con la aplicación automática de todos los deberes de los administradores y el régimen de la responsabilidad regulado en el art. 236.1 LSC se deja abierta la posibilidad a que el administrador de hecho tenga que explicar, en el concreto caso enjuiciado, cuáles fueron sus posibilidades de actuación para poder cumplir con todos los deberes legales y los inherentes al cargo. En definitiva, que la exigencia de responsabilidad a un administrador de hecho 
dependerá de las posibilidades reales que tuvo para poder cumplir con las obligaciones legales establecidas en el art. 367 LSC.

OCTAVA. Los administradores de derecho se exoneran de los daños ocasionados como consecuencia de los actos realizados en el desempeño de su cargo atendiendo a la naturaleza de este y a las funciones que tenga atribuidas. Por tanto, la cuestión fundamental es cómo se exigirá responsabilidad al administrador de hecho conforme al proceso de diversificación que se ha establecido para la exigencia de la responsabilidad general de los administradores.

De este modo, será cada caso concreto y las circunstancias concurrentes en la actuación de los administradores de hecho las que determinarán si hubo incumplimiento de sus deberes de diligencia o de lealtad. Así, a título de ejemplo, en el frecuente supuesto de una situación económica crítica en la que tengan que decidir sobre una operación que entrañe un alto riesgo para la sociedad, difícilmente supondría, a priori, un quebranto del deber de lealtad de los administradores de hecho. En concreto, aplicando la regla del buen juicio empresarial, estudiada pormenorizadamente en este trabajo, si el administrador asume el riesgo empresarial y el cumplimiento de su diligencia se concreta con el ejercicio responsable del cargo, con profesionalidad y dedicación, con información necesaria para actuar racionalmente y con previsibilidad de resultados, a este no se le podrá responsabilizar del éxito o del fracaso de la operación. Así, aunque las decisiones empresariales adoptadas fueran erróneas, los tribunales no podrán ex post recriminarlas cuando se hayan adoptado siguiendo las reglas de la discrecionalidad empresarial o diligencia debida.

No obstante, siempre se deberán tener en cuenta las circunstancias de las personas, el tiempo y lugar para poder determinar si una actuación ha sido diligente y leal, y será, en todo caso, el sentido común el que determinará cuándo un administrador de hecho ha actuado como un ordenado empresario en defensa del interés de la sociedad.

NOVENA. Variada es la problemática que se plantea para exigir responsabilidad al administrador de hecho debido al perfil funcional que se utiliza en su definición legal. Uno de los problemas viene predeterminado por el modo de organizar la sociedad cuando se establece mediante un consejo de administración y dimana de su configuración colegiada porque, como es sabido, la responsabilidad se atribuye conjuntamente a todos sus miembros, a pesar de que 
algunos no hayan realizado el acto lesivo. En el caso del administrador de hecho, por ser precisamente un hecho, no se encuentra integrado dentro del consejo de administración y, en consecuencia, no podrán operar las excepciones previstas en el art. 237 LSC, a efectos de poder alegar que se opuso a la adopción del acuerdo lesivo.

Otra importante limitación para exigir responsabilidad al administrador de hecho es el supuesto de no haber solicitado la declaración del concurso. En concreto, en relación con la responsabilidad concursal prevista en el art. 172.2 LC, que exige la especial motivación para atribuirle responsabilidad concursal, se necesitará que la administración concursal aporte una prueba plena que permita al juzgador resolver congruentemente y bajo los principios procesales de la carga de la prueba y de justicia rogada, a fin de que motivada y adecuadamente se proceda a calificar el concurso como culpable por la actuación de la persona considerada como administrador de hecho.

Tras el análisis de los presupuestos de la responsabilidad concursal consideramos que la exigencia de la responsabilidad concursal no procedería en el administrador de hecho, por ejemplo, con respecto al retraso en la presentación de documentos, en la llevanza de la contabilidad, en la decisión de presentar la correspondiente declaración del concurso o en el retraso de la solicitud de la misma, porque son competencias que corresponden a los administradores de derecho.

Hay que advertir, aunque no sea objeto de estudio exhaustivo por su amplitud, la importancia en el ámbito de la responsabilidad penal de la introducción de los programas de compliance por los administradores y, en particular, por el administrador de hecho.

DÉCIMA. En síntesis, en nuestra opinión, solo el administrador de hecho oculto podrá cumplir con las obligaciones que corresponden a los administradores en la sociedad, porque es el que realmente administra la sociedad mediante sus instrucciones, las cuales son aceptadas sistemáticamente por los administradores de derecho y por la misma sociedad, ya que puede informarse de la marcha de la sociedad dictando sus órdenes a los que se encuentran revestidos de la formalidad necesaria para cumplir los deberes que impone la Ley y los inherentes al ejercicio del cargo. 


\section{BIBLIOGRAFÍA}


AA.VV., Estudios jurídicos en homenaje a Joaquín Garrígues, vol. II, Madrid, 1971.

AA.VV., Comentario al Régimen Legal de las Sociedades Mercantiles (Dir. URÍA, MENÉNDEZ Y OLIVENCIA), Ed. Cívitas, Madrid, 1992.

AA.VV., Comentarios a la Ley de Sociedades Anónimas, Ed. Revista de Derecho Privado, Madrid, 1994.

AA.VV., Estudios de Derecho mercantil en homenaje al Profesor Broseta Pons, vol. III, Ed. Tirant lo Blanch, Valencia, 1995.

AA.VV., Derecho de sociedades anónimas, v. I, Ed. Cívitas, Madrid, 1996.

AA.VV., El gobierno de las sociedades cotizadas (Coord. ESTEBAN VELASCO), Ed. Marcial Pons, Madrid, 1999.

AA.VV., La responsabilidad de los administradores de las sociedades de capital (Coord. GALÁN CORONA Y GARCÍA-CRUCES GONZÁLEZ), Ed. Tecnos, Madrid, 1999.

AA.VV., La responsabilidad de los administradores de sociedades de capital. Ed. Estudios de Derecho Judicial, núm. 24, Madrid, 1999.

AA.VV., La responsabilidad de los administradores de las sociedades de capital, Ed. Estudios de Derecho Judicial (CGPJ y Consejo General del Notariado), Madrid, 2000.

AA.VV., Cometarios a la Ley de Sociedades Anónimas (Coord. ARROYO-EMBID), t. II, Ed. Tecnos, Madrid, 2001.

AA.VV., Contratos mercantiles (Coord. BERCOVITZ RODRIGUEZ-CANO), Ed. Aranzadi, Cizur Menor, 2001.

AA.VV., Derecho de Sociedades. Libro Homenaje a Fernando Sánchez Calero, vol. II, Ed. MacGraw Hill, Madrid, 2002.

AA.VV., Estudios sobre el anteproyecto de la Ley concursal de 2001 (Dir. GARCÍA VALVERDE, ALONSO UREBA Y PULGAR EZQUERRA), Ed. Dilex, Madrid, 2002.

AA.VV., Derecho Concursal. Estudio sistemático de la Ley 22/2003 y de la Ley 8/2003 para la reforma concursal, Ed. Dilex, Madrid, 2003.

AA.VV., Descentralización productiva y responsabilidades empresariales. El “outsourcing” (Dir. RIVERO LAMAS), Ed. Aranzadi, Pamplona, 2003.

AA.VV., Estudio sistemático de la Ley 22/2003 y de la Ley 8/2003, para la reforma concursal (Dir. GARCÍA VILLAVERDE, ALONSO UREBA Y PULGAR EZQUERRA), Ed. Dilex, Madrid, 2003.

AA.VV., La reforma de la legislación concursal (Dir. ROJO FERNÁNDEZ-RÍO), Ed. Marcial Pons, Madrid, 2003. 
AA.VV., Comentarios a la Ley Concursal (Coord. FERNÁNDEZ DE LA GÁNDARA Y SÁNCHEZ ÁLVAREZ), Ed. Marcial Pons, Madrid, 2004.

AA.VV., La responsabilidad de los administradores de las sociedades mercantiles (Dir. ROJO FERNÁNDEZ-RÍO Y BELTRÁN SÁNCHEZ), Ed. Tirant lo Blanch, Valencia, 2005, 2008, 2012, 2013 y 2016.

AA.VV., Estudios sobre la ley Concursal. Libro Homenaje a D. Manuel Olivencia, t. V, Ed. Marcial Pons, Madrid, 2005.

AA.VV., Gobierno corporativo y crisis empresariales, Ed. Marcial Pons, Madrid, 2006.

AA.VV., Diccionario de derecho de sociedades, Ed. Iustel, Madrid, 2006.

AA.VV., Las NIC. Análisis y Aplicación (Coord. CAÑIBANO CALVO), Navarra, 2006.

AA.VV., Derechos de sociedades cotizadas, t II, Ed. Thomson-Aranzadi, 2006.

AAVV., Mitos y realidades de la responsabilidad social corporativa, un enfoque multidisciplinar, Ed. Thomson, Cizur Menor, 2006.

AA.VV., Estudios de derecho de sociedades y derecho concursal. Libro homenaje al Prof. García Villaverde, tomo II, Ed. Marcial Pons, Madrid, 2007.

AA.VV., Órganos de la sociedad de capital (Dir. GIMENO-BAYÓN COBOS Y GARRIDO ESPA), Ed. Tirant lo Blanch, Valencia, 2008.

AA.VV., Tendencias actuales en la ordenación del control y el capital en las sociedades mercantiles (Dir. LEÓN SANZ), Ed. Marcial Pons, Madrid, 2009.

AA.VV., Estudios de derecho mercantil en memoria del Profesor Aníbal Sánchez Andrés (Coord. SÁENZ GARCÍA DE ALBIZU, OLEO BANET Y MARTÍNEZ FLORA), Ed. Thomson Reuters, Ed. Cívitas, Madrid, 2010.

AA.VV., Responsabilidad social de la empresa y derecho mercantil (Dir. EMBID IRUJO), Ed. Comares, Murcia, 2010.

AA.VV., Cuestiones pendientes de reforma (Dir. ALONSO UREBA Y ESTEBAN VELASCO), t. I, Madrid, 2011.

AA.VV., Comentarios de la Ley de sociedades de capital (Dir. ROJO FERNÁNDEZ- RIO Y BELTRÁN SÁNCHEZ), t. 1, Ed. Cívitas, Cizur Menor, 2011.

AA.VV., La responsabilidad de los administradores de sociedades de capital (administradores de hecho, administrador oculto y grupo de sociedades), (Coord. GUERRA MARTÍN), Ed. La Ley, Madrid. 2011. 
AA.VV., Cuaderno de derecho para ingenieros. Hacia un nuevo gobierno corporativo (reforma desde la desconfianza de los mercados), (Coord. ALONSO UREBA), Ed. La Ley, Madrid, 2013.

AA.VV., Introducción al derecho de sociedades de capital. Estudio de la ley de sociedades de capital y legislación complementaria, (Dir. EMBID IRUJO), Ed. Marcial Pons, Ediciones Jurídicas y Sociales, Madrid, 2013.

AA.VV., Gobierno corporativo en sociedades no cotizadas (Dir. HIERRO ANIBARRO), Ed. Marcial Pons, Madrid, 2014.

AA.VV., Hacia un nuevo Código Mercantil (Coord. BERCOVITZ RODRÍGUEZ-CANO), Ed. Thomson Reuters Aranzadi, Cizur Menor, 2014.

AA.VV., Archivo Commenda de jurisprudencia societaria (Dir. EMBID IRUJO), Ed. Comares, Granada 2011/2012, 2013/2014.

AA.VV., La reforma de la Ley de sociedades de capital en materia de gobierno corporativo (Dir. GARCÍA DE ENTERRÍA), Ed. Thomson Reuters Aranzadi, Cizur Menor, 2015.

AA.VV., Régimen de deberes y responsabilidad de los administradores en las sociedades de capital (Coord. HERNANDO CEBRIÁ), Ed. Bosch, Barcelona, 2015.

AA.VV., Gobierno corporativo: la estructura del órgano de gobierno y la responsabilidad de los administradores" (Dir. MARTÍNEZ-ECHEVARRÍA Y GARCÍA DUEÑAS), Ed. Thomson Reuters Aranzadi, Cizur Menor, 2015.

AA.VV., Junta General y Consejo de administración en la sociedad cotizada (Coord. RONCERO SÁNCHEZ), t. II, Ed. Aranzadi, Cizur Menor, 2015.

AA.VV., Comentario Práctico a la nueva normativa de gobierno corporativo (Dir. ALBIÑA Y SUÁREZ LESO), Ed. Dikinson, Madrid, 2015.

AA.VV., Comentario de la reforma del régimen de las sociedades de capital en materia de gobierno corporativo (Ley 31/2014) (Coord. JUSTE MENCÍA), Ed. Thomson Reuters Aranzadi, Cizur Menor, 2015.

AA.VV., Lecciones de derecho mercantil (Coord. MENÉNDEZ MENÉNDEZ Y ROJO FERNÁNDEZ-RÍO), Ed. Cívitas, Madrid, 2017.

AA.VV., Estudios sobre los órganos de las sociedades de capital (Coord. JUSTE MENCÍA Y ESPÍN GUTIÉRREZ), v. I y II, Ed. Aranzadi, Cizur Menor, 2017.

AA.VV., Derecho de sociedades. Revisando el derecho de sociedades de capital (Coord. OLMEDO PERALTA Y GALACHO ABOLAFIO), Ed. Tirant Lo Blanch, Valencia 2018. 
AA.VV., Estudio sobre la responsabilidad de los administradores de las sociedades de capital a la luz de sus recientes reformas legislativas y pronunciamientos judiciales (Dir. DÍAZ MORENO Y VÁZQUEZ CUETO), Ed. Aranzadi, Cizur Menor, 2018.

AA.VV., Derecho de sociedades Anónimas cotizadas (Estructura de Gobierno y Mercados), (Coord. RODRÍGUEZ ARTIGAS), vol. II, 2006

ABRIANI, "Gli amministratori di fatto della società de capitali”, en Quaderni di Giurusprudenza commerciale, Ed. Giuffrè. Milano 1998.

- "Riforma del diritto societario e responsabilità dell amministratore di fatto: verso una nozione unitaria dell instituto", Revista La società, núm.2, 2000. p. 216

ALBIÑA CIVLETI, C., "Líneas generales de la Ley de Sociedades de Capital", en AA.VV., Comentario Práctico a la nueva normativa de gobierno corporativo (Dir. ALBIÑA Y SUÁREZ LESO), Ed. Dikinson, Madrid, 2015, pp.17-24.

ALBORCH BATALLER, C., El derecho de voto de los accionistas, Ed. Tecnos, Madrid, 1997.

ALCOVER GARAU, G., "Consideraciones generales sobre la alternativa de la reforma propuesta de derecho concursal español”, RdS, núm. 6, 1996, pp. 486-488.

- "Aproximación de la naturaleza jurídica de la responsabilidad concursal de los administradores de las sociedades de capital”, RDCP, núm. 7, 2007, pp. 91-108.

ALEJO GARMENDIA, B., Los deberes de diligencia y de lealtad de los administradores en las empresas, Ed. Thomson Reuters Proview, Cizur Menor, 2017.

ALFARO ÁGUILA-REAL, J., "La llamada acción individual de responsabilidad contra los administradores", $R d S$, núm. 18, 2002, pp. 45-47.

- "Sobre administradores de hecho y subordinación de créditos, arts. 92 y 93 LC", http:/Dialnet.nirioja.es, Madrid, 19 de abril de 2012.

- "La protección de la discrecionalidad empresarial", en AA.VV., Comentarios de la reforma del régimen de las sociedades de capital en materia de gobierno corporativo (Ley 31/2014), (Coord. JUSTE MENCÍA), Ed. Thomson Reuters, Cizur Menor, 2015, pp. 325-351.

- "Artículo 225. Deber general de diligencia" en AA.VV., Comentarios de la reforma, AA.VV., Comentario de la reforma del régimen de las sociedades de capital en materia de gobierno corporativo (Ley 31/2014), (Coord. JUSTE MENCÍA), Ed. Thomson Reuters, Cizur Menor, 201, pp. 313-356.

ALFARO AGUILA-REAL, J. Y GARCIA MARTÍN, F., "Sobre administradores de hecho y subordinación de créditos ex arts. $92 \quad$ y 93 LC", http://derechomercantilespana.Blogspot.com.es/2012/04/sobre-administradores-de-hecho-y.html. 
ALFONSO SÁNCHEZ, R., Obligaciones básicas del deber de lealtad: art. 228”, en AA.VV., Régimen de deberes y responsabilidad de los administradores en las sociedades de capital (Coord. HERNANDO CEBRIÁ), Ed. Bosch, Barcelona, 2015, pp. 187-234.

ALONSO UREBA, A., "Presupuestos de la responsabilidad social de los administradores de una sociedad anónima”, RDM, núm. 198, octubre-diciembre, 1990, pp. 673-674.

- "Presupuestos de la responsabilidad social de los administradores de una SA", RDM, 1991, pp. 639 y ss.

- "El gobierno de las grandes empresas (Reforma legal versus Código de conducta)", en AA.VV., El gobierno de las sociedades cotizadas (Coord. ESTEBAN VELASCO), Ed. Marcial Pons, Madrid, 1999, pp. 105 y 106.

- "La responsabilidad de los administradores de una sociedad de capital en situación concursal (el art. 171.3 del Anteproyecto de Ley Concursal y sus relaciones con las acciones societarias de responsabilidad)", en Estudios sobre el anteproyecto de Ley Concursal de 2001 (Dir. GARCÍA VALVERDE, ALONSO UREBA Y PULGAR EZQUERRA), Ed. Dilex, Madrid, 2002, pp. 263-313.

- "Hacia un modelo monista revisado de administración de las SA cotizada como opción al modelo dualista en la modernización del derecho de sociedades de capital en España. Cuestiones pendientes de reforma", en AA.VV., Cuestiones pendientes de reforma (Dir. ALONSO UREBA Y ESTEBAN VELASCO), t. I, Madrid, 2011, pp. 561- 639.

- "Algunas cuestiones en relación con el ámbito subjetivo de la responsabilidad de los administradores (administradores de hecho, administrador oculto y grupos de sociedades)", en AA.VV., La responsabilidad de los administradores de sociedades de capital (administradores de hecho, administrador oculto y grupos de sociedades), (Coord. GUERRA MARTÍN), Ed. La Ley, Madrid. 2011. pp. 255 y ss.

- “Administrador de hecho y grupo de sociedades”, Otrosí, núm. 12, octubre-diciembre, 2012, p. 25.

- "Mejoras en la estructura y calidad de las decisiones del Consejo", en AA.VV., Cuaderno de derecho para ingenieros. Hacia un nuevo gobierno corporativo (reforma desde la desconfianza de los mercados), (Coord. ALONSO UREBA), Ed. La Ley, Madrid, 2013, pp. 13-30.

- "Liderazgo en el consejo vs liderazgo en la dirección (la interactividad entre la supervisión y la dirección efectiva)", en AA.VV., Cuaderno de derecho para ingenieros. Hacia un nuevo gobierno corporativo (reforma desde la desconfianza de los mercados), (Coord. ALONSO UREBA), Ed, La Ley, Madrid, 2013, pp. 11-29.

- "El modelo de consejo de administración de la sociedad cotizada tras la reforma legal de 2014 y el CBG de 2015", en AA.VV. Junta General y Consejo de administración en la sociedad cotizada (Coord. RONCERO SÁNCHEZ), t. II, Ed. Aranzadi, Cizur Menor, 2015, pp. 27-147. 
ALONSO UREBA, A. Y PULGAR EZQUERRA, A., "Relación de grupo y administrador de hecho en el concurso de sociedades integradas en un grupo", en $R d S$, núm. 28, 2007, pp. 19-37.

ÁLVAREZ CAZENAVE, C. I., "Causas legales de disolución: estado de la jurisprudencia”, en AA.VV., Derecho de sociedades, Revisando el derecho de sociedades de capital (Coord. GONZÁLEZ FERNÁNDEZ Y GALACHO ABOLAFIO), Ed. Tirant Lo Blanch, Valencia, 2018, pp. 1588-1609.

ARANGUREN URRIZA, F. J., "Protocolos y pautas de actuación de los administradores", en AA.VV., Régimen de deberes y responsabilidades de los administradores en las sociedades de capital (Coord. HERNANDO CEBRIÁ), Ed. Bosch, Barcelona, 2015, pp. 427-465.

ARRIBA FERNÁNDEZ, M. L., Derecho de grupos de grupos sociedades, Ed. Bosch, Madrid, 2004. ARROYO MARTíNEZ, I., “Artículo 133”, en AA.VV., Cometarios a la Ley de Sociedades Anónimas, (Coord. ARROYO-EMBID), Ed. Tecnos, Madrid, 2001, p. 1415.

ASCARELLI, T., "In tema di vendita di azioni, responsabilità degli amministratori. Amministratore indirecto", en Foro It., 1953, pp. 1630 y ss.

BARTALINI, G., La responsabilità degli amministratori e de director generali di società per azioni, Turín, 2000.

BATALlER GRAU, F., “Artículo 363”, en AA.VV., Comentarios de la Ley de sociedades de capital (Dir. ROJO FERNÁNDEZ-RÍO Y BELTRÁN SÁNCHEZ), t. II, Ed. Cívitas, Madrid, 2011, pp. $2547-$ 2559.

BELLO MARTÍN-CRESPO, P., "Responsabilidad de los administradores de sociedades de capital y Ley concursal, en Estudios sobre la Ley Concursal. Libro Homenaje a Manuel Olivencia, t. V, Ed. Marcial Pons, Madrid, 2005, pp. 1679 y ss.

BELTRÁN SÁNCHEZ, E. Y ROJO FERNÁNDEZ-RÍO, A., "El capital social mínimo. Consideraciones políticas y técnica legislativa”, en RDM, 1988, pp. 149-189.

- La disolución de la sociedad anónima, Ed. Cívitas, Madrid, 1991.

- "Pérdidas y responsabilidad de los administradores. (Comentarios a las Sentencias de la Audiencia Provincial de Zaragoza de 23 de noviembre de 1991, y de la Audiencia Provincial de Oviedo de 1 de diciembre de 1992)", en $R d S$, julio- septiembre 1992, pp. 471-486.

- "La responsabilidad por las deudas sociales de administradores de sociedades anónimas y limitadas incursas en causa de disolución", en $A C$, 1997-III, pp. 62 y ss.

- "Factor", en $E J B C$, I, pp. 3045 y ss. 
- "La responsabilidad de los administradores por las deudas sociales", en AA.VV., La responsabilidad de los administradores de las sociedades mercantiles (Dir. ROJO FERNÁNDEZ-RÍO Y BELTRÁN SÁNCHEZ), Ed. Tirant lo Blanch, Valencia, 2005, pp. 213-259.

- "La modificación legal del ámbito objetivo del ámbito objetivo de responsabilidad de los administradores por las obligaciones sociales", en $A D C, 2006$, p. 253.

- "En torno a la naturaleza de la responsabilidad concursal comentario a la sentencia de la Sección 2 de la Audiencia Provincial de Madrid de 5 de febrero de 2008". Artículo integrante del Proyecto de Investigación "La Reforma del Derecho concursal español. Antecedentes y objetivos", en $A D C$, núm.14, 2008.

- "La responsabilidad de los administradores por obligaciones sociales" en AA.VV., La responsabilidad de los administradores de las sociedades mercantiles (Dir. ROJO FERNÁNDEZ-RÍO Y BELTRÁN SÁNCHEZ), Ed. 6ª Tirant Lo Blanch, Valencia, 2016 p. 301-352.

BERCOVITZ RODRÍGUEZ-CANO, A., "Régimen general de la responsabilidad civil de los administradores de las sociedades de capital", en AA.VV., La responsabilidad de los administradores de las sociedades de capital (Coord. GALÁN CORONA Y GARCÍA-CRUCES GONZÁLEZ), Ed. Tecnos, Madrid, 1999, pp. 15-25.

- Comentarios al Código Civil, Ed. Thomson Aranzadi, Cizur Menor, 2006.

- "Presentación del Anteproyecto de Código Mercantil", en AA.VV., Hacia un nuevo Código Mercantil (Coord. BERCOVITZ RODRÍGUEZ-CANO), Ed. Thomson Reuters Aranzadi, Cizur Menor, 2014, pp. 37-54.

BERLE, A., Y MEANS, G., La modern corporation and private property, New York, 1932.

BERNAD RIPOLL, F. Y LÓPEZ IGLESIAS, L., "La responsabilidad de los administradores en procesos de refinanciación", en AA.VV., Gobierno corporativo: la estructura del órgano de gobierno y la responsabilidad de los administradores (Dir. MARTÍNEZ-ECHEVARRÍA Y GARCÍA DUEÑAS), Ed. Thomson Reuters Aranzadi, Cizur Menor, 2015, pp. 1117-1204.

BIANCO, M. Y CASAVOLA, P., "Corporate Governance in Italia: Alcuni fatti e problemi aperti”, en Revista La Società, 1996, pp. 426 y ss.

BIGIAVI, C. W., "Responsabilità Illimitata del socio tiranno", en Il Foro Italiano, 1960, I c, pp.1180 y ss.

BLANQUER UBEROS, R., "La disolución, la liquidación y la extinción de la sociedad”, en Anales de la Academia Matritense del Notariado, t. XXX, v. I, RDP, Madrid, 1991 pp. 490-491.

BLASCO GASCÓ, F., Responsabilidad Concursal y embargo de los bienes de los acreedores, Ed. Tirant lo Blanch, Valencia, 2007. 
BOLAS ALFONSO, J. M., "La financiación de la actividad social de las sociedades de capital y la situación de pérdidas desde la perspectiva del derecho mercantil actual”, Revista de Derecho Privado, abril, 1994, pp. 307-332.

BOLDÓ RODA, M. C., "Levantamiento del velo de la persona jurídica en el derecho privado española", RdS, Aranzadi, 1997.

- Levantamiento del velo y persona jurídica en el Derecho privado español, Ed. Thomson-Aranzadi, $4^{\mathrm{a}}$ ed. Pamplona, 2006.

- "Deber de evitar situaciones de conflicto de interés y personas vinculadas a los administradores: artículos 229 y 251", en AA.VV., Régimen de deberes y responsabilidad de los administradores en las sociedades de capital (Coord. HERNANDO CEBRIÁ), Ed. Bosch, Barcelona, 2015, pp. 241-279.

BONELLI, F., "La responsabililità degli admministratori”, Tratato della soccietà per azioni, Torino, 1991, pp. 323-484.

BORNARDELl LENZANO, R., Régimen jurídico de la contabilidad del empresario, Ed. Marcial Pons, Madrid, 2012.

BRATTACHARYYA, G., "ReHydrodan Corby Ltd-Shadow director and wronful trading", Com. L., mayo 1954, pp. 151 y ss.

BRENES CORTÉS, J., "La responsabilidad del representante persona física del administrador persona jurídica”, en AA.VV., Estudio sobre la responsabilidad de los administradores de las sociedades de capital a la luz de sus recientes reformas legislativas y pronunciamientos judiciales (Dir. DÍAZ MORENO Y VÁZQUEZ CUETO), Ed. Aranzadi, Cizur Menor, 2018, pp. 80-121.

http://www.broseta.com/2014/12/04/analisisi-de-la-nueva-ley-de-sociedades-de capital/\#.VOchCeaG_To.

BUIREU GUARRO, J., Manuel de Contabilidad General, ed. 4ª Madrid, 1983.

CAMPBELL, N. R., "Liability as Shadow Director". Jrnal. B.L, 1994, pp. 609 y ss.

CAMPUZANO LAGUILLO, A. B., "La acción social de responsabilidad (artículos 238 a 240 de la Ley de sociedades de capital)", en AA.VV., Gobierno corporativo: la estructura del órgano de gobierno y la responsabilidad de los administradores (Dir. MARTÍNEZ-ECHEVARRÍA Y GARCÍA DUEÑAS), Ed. Thomson Reuters Aranzadi, Cizur Menor, 2015, pp. 765-783.

CAÑIBANO CALVO, L., Contabilidad Análisis contable de la realidad económica, Madrid, 1991.

CAPILLA RONCERO, F., Las personas jurídicas funciones y disfunciones, Ed. Tecnos, Madrid, 1994. 
CAPONI, R., "Socio predominante e rischico di empresa", en Rivista Diritto Commerciale, TI, 1989, pp. 381 y ss.

CAVALLI, G., MARULLI, M., Y SILVETTI, C., Le società per azioni, ed. 3ª Torino, 1996.

CAZORLA GOZÁLEZ-SERRANO, L, “Administradores sociales, deber de diligencia y programas de cumplimiento penal (una perspectiva mercantil del cumplimiento normativo", en AA.VV., Derecho de sociedades., Revisando el derecho de sociedades de capital (Coord. OLMEDO PERALTA Y GALACHO ABOLAFIO), Ed. Tirant Lo Blanch, Valencia, 2018, pp. 1259-1261.

CID BLASCO, T. Y GARCÍA BIGUAZZI, T., "El régimen de responsabilidad de los administradores", en AA.VV., La reforma de la Ley de sociedades de capital en materia de gobierno corporativo (Dir. GARCÍA DE ENTERRÍA), Ed. Thomson Reuters- Aranzadi, Cizur Menor, 2015, pp. 71-79.

CIFREDO ORTIZ, P., "La acción individual de responsabilidad de los administradores y la carga de la prueba", en AA.VV., Derecho de sociedades, Revisando el derecho de sociedades de capital (Coord. GONZÁLEZ FERNÁNDEZ Y GALACHO ABOLAFIO), Ed. Tirant Lo Blanch, Valencia, 2018, pp. 1315-1328.

CONDE TEJÓN, A., "El derecho de información de los socios como medio de control de la actuación de los administradores. El difícil equilibrio para evitar los supuestos de abuso. Propuestas prácticas de mejora”, en AA.VV., Estudios sobre órganos de las sociedades de capital, v. I, Ed. Aranzadi, Cizur Menor, 2017, pp. 534-562.

CONTRERAS DE LA ROSA, I., "La persona jurídica administradora en las sociedades de capital: entresijos de una relación a tres bandas", en AA.VV., Derecho de sociedades, Revisando el derecho de sociedades de capital (Coord. GONZÁLEZ FERNÁNDEZ Y GALACHO ABOLAFIO), Ed. Tirant Lo Blanch, Valencia, 2018, pp. 903-937.

CUENCA MIRANDA, S., "Las competencias del consejo de administración. Las facultades indelegables del consejo. La política de control y gestión de riesgos en las sociedades cotizadas", en AA.VV., Gobierno corporativo: la estructura del órgano de gobierno y la responsabilidad de los administradores" (Dir. MARTÍNEZ-ECHEVARRÍA Y GARCÍA DUEÑAS), Ed. Thomson Reuters Aranzadi, Cizur Menor, 2015, pp. 647-683.

CULUBERT, I. Y TORRES, A., "Delegación de facultades por el consejo y facultades indelegables", en AA.VV., La reforma de la Ley de sociedades de capital en materia de gobierno corporativo (Dir. GARCIA DE ENTERRIA), Ed. Thomson Reuters- Aranzadi, Cizur Menor, 2015, pp. 81-90.

DE ÁNGEL YAGÜEZ, R., Doctrina del levantamiento del velo de la persona jurídica en la jurisprudencia, Ed. Cívitas, Madrid, 1997.

DE ARRIBA FERNÁNDEZ, M. L., Derecho de grupo de sociedades, Ed. Thomson Cívitas, 2009. 
DEDESSUS-LE-MOSTIEUR, N., "La responsabilité du dirigeant de fait”, Rev. Soc., 1970, p. 503.

DE EIZAGUIRRE ECHEVARRÍA R., "Disolución y liquidación. Obligaciones", en AA.VV., Comentarios a la Ley de sociedades anónimas (Dir. SÁNCHEZ CALERO), tomo VIII, en RDP, Madrid, 1993, pp. 1016-1018.

DEL CASTILLO IONOV, R., "La información societaria (II): La contabilidad, el deber de información complementaria en la memoria y los instrumentos especiales de información (artículos 536, y 539 en la Ley de sociedades de capital)", en AA.VV., Gobierno Corporativo y crisis empresariales, Ed. Marcial Pons, Madrid 2006, pp. 951-977.

DEL VAL TALENS, P., El administrador persona jurídica en las sociedades de capital, Ed. Marcial Pons, Madrid, 2017.

DÍAZ ECHEGARAY, J. L., La responsabilidad civil de los administradores de la sociedad anónima, Ed. Montecorvo, Madrid, 1995.

- "El contrato de distribución exclusiva o de concesión" en AA.VV., Contratos mercantiles (Coord. BERCOVITZ RODRÍGUEZ-CANO), Ed. Aranzadi, Cizur Menor, 2001, pp. 296 y ss.

- El administrador de hecho de las sociedades, Ed. Aranzadi, Pamplona, 2002.

- Deberes y responsabilidad de los administradores de sociedades de capital: conforme a la Ley 26/2003, de 17 de julio, Ed. Aranzadi, Pamplona, 2004.

- Presupuestos de la responsabilidad de los administradores concursales, Ed. Aranzadi, Cizur Menor, 2012.

DÍAZ MORENO, A., Responsabilidad y deberes de los administradores (notas acerca del nuevo régimen introducido por la "Ley de Transparencia”), Ed. IFEX, Madrid, 2003.

- "Observaciones sobre administradores, acuerdos de refinanciación, Fresh Money y subordinación", en AA.VV., Estudio sobre la responsabilidad de los administradores de las sociedades de capital a la luz de sus recientes reformas legislativas y pronunciamientos judiciales (Dir. DÍAZ MORENO Y VÁZQUEZ CUETO), Ed. Aranzadi, Cizur Menor, 2018, pp. 53-76.

DÍAZ RUÍZ, E., "El informe anual de gobierno corporativo (art. 540 LSC)", en AA.VV., Junta General y Consejo de administración en la sociedad cotizada (Coord. RONCERO SÁNCHEZ), t. II, Ed. Aranzadi, Cizur Menor, 2015, pp. 1039-1063.

- "La coordinación de los administradores solidarios de las sociedades de capital como manifestación del deber de diligencia”, en AA.VV., Estudios sobre los órganos de las sociedades de capital (Coord. JUSTE MENCÍA Y ESPÍN GUTIERREZ), v. I Ed. Aranzadi, Cizur Menor, 2017, pp. 1003-1021.

DÍEZ PICAZO, L., Derecho de daños, Ed. Tecnos, Madrid, 1999. 
- La prescripción extintiva en el Código civil y en la jurisprudencia del Tribunal Supremo, Ed. Cívitas, Madrid, 2007, pp. 2003-2005.

DUQUE DOMÍNGUEZ, J. F., "Concepto de grupo de sociedades y su significado en el derecho español", Derecho de sociedades. Libro Homenaje a Fernando Sánchez Calero, v. II, Ed. Mac Graw Hill, Madrid, 2002, pp. 5303-5322.

- "El concurso del grupo de empresas en la Ley Concursal", en AA.VV., Derecho Concursal. Estudio sistemático de la Ley 22/2003 y de la Ley 8/2003 para la reforma concursal, Ed. Dilex, Madrid, 2003.

EISENBERG, M., Corporations and other business organizations, Nueva York, 2005.

EMBID IRUJO, J. M., Grupos de sociedades y accionistas minoritarios (la tutela de la minoría en situaciones de dependencia societaria y grupo), Ed. Ministerio de Justicia, Madrid, 1987.

- "Medidas de defensa de una sociedad mercantil frente a la una acción exterior de obtención de control. Las cláusulas anti-opa”, en RDBB, núm. 39, 1990, pp. 535-548.

- "Grupos y gobierno corporativo" en AA.VV., El gobierno de las sociedades cotizadas, (Coord. ESTEBAN VELASCO), Ed. Marcial Pons, Madrid, 1999, pp. 595-612.

- Introducción al derecho de los grupos de sociedades, Ed. Comares, Granada, 2003.

- "El buen gobierno corporativo y los grupos de sociedades", RDM, n² 249, 2003.

- "La responsabilidad social corporativa ante el Derecho mercantil", Cuadernos de Derecho y Comercio, núm. 24, 2004, p. 26.

- "La responsabilidad de los administradores de la sociedad anónima tras la Ley de Trasparencia", RCDI, núm. 685, septiembre-octubre 2004, pp. 2379-2423.

- "Los deberes de los administradores en las sociedades cotizadas. El artículo 114 de la Ley del Mercado de Valores”, RDBB, núm. 6, 2004, pp. 7 y ss.

- "Grupos de Sociedades y Derecho concursal”, en AA.VV. Estudios sobre la Ley concursal. Libro Homenaje a Olivencia. Madrid, 2005, T.III, pp. 1885 y ss.

- "Apuntes sobre los deberes de fidelidad y lealtad de los administradores de las sociedades anónimas", $C D C$, núm. 46, 2006, pp. 9 y ss.

- "Un paso adelante y varios a tras: sobe vicisitudes recientes del concepto legislativo del grupo en el ordenamiento español", $R d S$, 2008-1, p. 19.

- Recensión al libro: El deber de diligente administración en el marco de los deberes de los administradores sociales. La regla del buen juicio empresarial de Luis Hernando Cebriá, Madrid, 2009. 
- Sobre el derecho de sociedades de nuestro tiempo. Crisis económica y ordenamiento societario, Ed. Comares, Granada, 2013.

- http://commenda.es/atualidad_interior/230/la-ley-312014-y-el-retorno-de-las-normas -imperativas.

- “Todos son (y serán) administradores", 23 de diciembre de 2014. http://commenda.es/actualidad_interior/234/todos-son-y-seran-administradores.

- "La protección de la discrecionalidad empresarial", en AA.VV., Régimen de deberes y responsabilidad de los administradores en las sociedades de capital (Coord. HERNANDO CEBRÍA), Ed. Bosch, Barcelona, 2015, pp. 105-131.

- "La mejora del gobierno corporativo y el régimen de deberes y responsabilidad de los administradores en las sociedades de capital”, en AA.VV., Régimen de deberes y responsabilidad de los administradores en las sociedades de capital (Coord. HERNANDO CEBRÍA), Ed. Bosch, Barcelona, 2015, pp. 27-58.

- "La protección de la discrecionalidad empresarial", en AA.VV., Régimen de deberes, deberes y responsabilidad de los administradores en las sociedades de capital (Coord. HERNANDO CEBRÍA), Ed. Bosch, Barcelona, 2015, pp. 105-131.

- "Algunos criterios de política jurídica para la regulación de los grupos de sociedades" en AA.VV., Derecho de sociedades. Revisando el derecho de sociedades de capital (Coord. OLMEDO PERALTA Y GALACHO ABOLAFIO), Ed. Tirant Lo Blanch, Valencia, 2018, pp. 355- 382.

ESCRIBANO GÁMIR, M. C., "Humano, demasiado humano: el enriquecimiento injusto del administrador desleal", en AA.VV., Estudios sobre órganos de las sociedades de capital (Coord. JUSTE MENCÍA Y ESPÍN GUTIÉRREZ), v. I, Ed. Aranzadi, Cizur Menor, 2017, pp. 1079-1099, pp. 1012-1013.

ESPEJO HINOJOS, R., Curso de Derecho mercantil, t. II, Ed. Bosch, Barcelona, 1940.

ESPÍN GUTIÉRREZ, C., "Las cuentas anuales de la sociedad anónima como objeto del derecho de información y como objeto de aprobación por la junta general", en AA.VV., Estudios sobre órganos de las sociedades de capital, v. I RdS, Cizur Menor, 2017, pp.566-604.

ESTEASÉN, P., Instituciones de Derecho mercantil, t. III, Madrid, 1892.

ESTEBAN VELASCO, G., "Configuración estatuaria del órgano de administración”, en Derecho de sociedades anónimas: Homenaje al profesor José Girón Tena (Coord. ALONSO UREBA), Ed. Cívitas, Madrid, 1991, p. 359.

- "Algunas reflexiones sobre la responsabilidad de los administradores frente a los socios y terceros: Acción individual y acción por no promoción o remoción de la disolución", $R d S$. núm. 5, 1995, pp. 47-78. 
- "Derecho de información del accionista", en AA.VV., Derecho de sociedades anónimas, v. I, Ed. Cívitas, Madrid, 1996, pp. 172 y ss.

- "El gobierno de las grandes empresas (reforma legal versus códigos de conducta)", en AA.VV., El gobierno de las sociedades cotizadas, (Coord. ESTEBAN VELASCO), Ed. Marcial Pons, Madrid, 1999, pp. 95-209.

- "La acción social y la acción individual de responsabilidad contra los administradores de las sociedades de capital”, en AA.VV., La responsabilidad de los administradores de sociedades de capital, Estudios de Derecho Judicial, núm. 24, Madrid, 1999, pp. 57 y ss.

- "La renovación de la estructura de la administración en el marco del debate sobre el gobierno corporativo" en AA.VV., El gobierno de las sociedades cotizadas (Coord. ESTEBAN VELASCO), Ed. Marcial Pons, Madrid, 1999, pp. 137-209.

- “¿Una nueva manera de entender e impulsar la evolución del sistema de gobierno de las sociedades cotizadas?", en AA.VV., El gobierno de las sociedades cotizadas (Coord. ESTEBAN VELASCO), Ed. Marcial Pons, Madrid, 1999.

- "La propuesta de la directiva sobre la "Societá unius personae" (SUP): las cuestiones más polémicas", Notario del siglo, 27 de marzo de 2015.

- "Distribución de competencias entre la junta general y el Órgano de administración, en particular las nuevas facultades de la junta sobre activos esenciales", en AA.VV., Junta General y Consejo de administración en la sociedad cotizada (Coord. RONCERO SÁNCHEZ), t. II, Ed. Aranzadi, Cizur Menor, 2015, pp. 29-82.

- "La acción individual de responsabilidad" en AA.VV., La responsabilidad de los administradores de las sociedades mercantiles (Dir. ROJO FERNÁNDEZ-RÍO Y BELTRÁN SÁNCHEZ), Ed. 6a , Tirant Lo Blanch, Valencia, 2016, pp. 189-298.

FARRAR, S., Company law, Ed. $4^{\circ}$, London 1998.

FATTORI, I., “Amministrazione di fattto e azione di responsabilità individual”, Revista La Società, Milan, 1994, p.256.

FELIÚ REY, J. Y RODRÍGUEZ DE LAS HERAS BALLELL, T., "La proyectada reforma del derecho de sociedades en el Reino Unido", Derecho de los negocios, núm. 194, noviembre 2006, pp. 25-33.

FERNÁNDEZ ALBOR BALTAR, A., "Deber de lealtad del administrador cesado. Observaciones a la sentencia de la Audiencia Provincial de Pontevedra de 18 de septiembre de 1997”, RGD, núm. 655, 1999, pp. 3991-4011. 
FERNÁNDEZ DE LA GÁNDARA, L., La atipicidad en derecho de sociedades, Ed. Pórtico, Zaragoza, 1977.

FERNÁNDEZ DE LA GÁNDARA Y SÁNCHEZ ÁLVAREZ, Ma', "Los delitos societarios, reflexiones preliminares sobre la imposición de acuerdos sociales abusivos", AJA, núm 238, 1996,

- Responsabilidad de Consejeros y Altos Cargos de Sociedades de Capital, Ed. McGraw Hill, Madrid, 1996.

- "El régimen de responsabilidad de los administradores", en La Ley de Sociedades Anónimas: Supuestos, principios y problemas, en la responsabilidad del administrador en las sociedades, Boletín del Ilustre Colegio de Abogados de Madrid, núm. 5 de junio, 1997, pp. 47 y ss.

- "El debate actual sobre el gobierno corporativo: aspectos metodológicos y de contenido", en AA.VV., El gobierno de las sociedades cotizadas (Coord. ESTEBAN VELASCO), Ed. Marcial Pons, Madrid, 1999, pp. 55-93.

- "La responsabilidad concursal de los administradores de sociedades de capital, en AA.VV., Comentarios a la Ley Concursal (Coord. FERNÁNDEZ DE LA GÁNDARA Y SÁNCHEZ ÁLVAREZ, Ed. Marcial Pons, Madrid, 2004, pp.701-721.

- Derecho de Sociedades, Ed. Tirant Lo Blanch, Valencia 2010.

- "Profesionalidad y diligencia constituyen dos caras de una misma moneda", $R d S, 2010$, p. 738.

- "Políticas/decisiones relevantes en materia de gestión/dirección: prohibición de delegación de facultades, reserva de decisiones estratégicas. Y relaciones al respecto entre consejo y dirección", en AA.VV., Junta General y Consejo de administración en la sociedad cotizada (Coord. RONCERO SÁNCHEZ), t. II, Ed. Aranzadi, Cizur Menor, 2015, pp. 181-226.

FERNÁNDEZ PÉREZ, N., "La "Companies" de 2006 y las singularidades de Buen Gobierno. Características del Derecho Ingles", en AA.VV., Junta General y Consejo de Administración, (Coord. RONCERO SÁNCHEZ), t. II, Ed. Aranzadi, Cizur Menor, 2015, pp. 1235-1256.

FERNÁNDEZ SEIJÓ, J. Mª, "Las acciones de responsabilidad en el ámbito mercantil. Enriquecimiento injusto del administrador. Novedades tras la reforma y última jurisprudencia" en AA.VV., Derecho de sociedades, Revisando el derecho de sociedades de capital (Coord. GONZÁLEZ FERNÁNDEZ Y GALACHO ABOLAFIO), Ed. Tirant Lo Blanch, Valencia, 2018, pp. 1285-1294.

FRANQUET, J. F., "La ausencia de inscripción en el Registro del cese de los administradores y el problema de su responsabilidad", Boletín del Centro de estudios Registrales de Cataluña, núm. 87, 2000. 
FRASCAROLI SANTI, E., "Controlo della banca sull utilizzazione dei fondi e il dirigente di fatto", CI, 1996,2, pp. 830-832.

FONT GALÁN, J. A., El derecho de información de los administradores. Fundamentación y disciplina, Ed. Espinosa, Córdoba, 2002.

- "El deber de diligente administración en el nuevo sistema de deberes de los administradores sociales”, en $R d S$ núm. 25, 2005, pp. 71 y ss.

FUENTES NAHARRO, N., "Una aproximación al concepto de administrador de hecho", en AA.VV., Gobierno corporativo y crisis empresariales. EI Seminario Harvard-Complutense de derecho mercantil, Ed. Marcial Pons, Madrid 2006, pp. 289-310.

- "La funcionalidad de la figura del administrador de hecho como vía de imputación de responsabilidades intra grupo (una aproximación a la delimitación conceptual de la figura)", II Harvard-Complutense Seminar on Busuness Law Corporate covernance conflicts and corporate insolvency, www.ucm.es, 2006, pp. 17-19.

- "Administrador de hecho", en AA.VV., Diccionario de derecho de sociedades, Ed. Iustel, Madrid, 2006.

- Grupos de sociedades y protección de los acreedores (una perspectiva societaria), Ed. Thomson Cívitas, Cizur Menor, 2007.

GACTO FERNÁNDEZ, E., Temas de historia del derecho: derecho del constitucionalismo y la codificación, Universidad de Sevilla, 1975.

GALACHO ABOLAFIO, A.F., "La Junta General y su competencia /obligación tras la reforma de la Ley de Sociedades de Capital", en AA.VV., Derecho de Sociedades, Revisando el derecho de sociedades de capital (Coord. GONZÁLEZ FERNÁNDEZ Y GALACHO ABOLAFIO), Ed. Tirant Lo Blanch, Valencia, 2018, pp. 749-775.

GALGANO CALVO, F., El negocio jurídico. Traducción realizada por Francisco de P. Blasco Gascó y Lorenzo Prats Albentosa, Ed. Tirant lo Blanch, Valencia, 1992.

GALLEGO SÁNCHEZ, E., “Articulo 2”, Comentarios a La Ley Concursal, Madrid, 2005.

- El director general de las sociedades anónimas y de responsabilidad limitada, Ed. La Ley, Madrid, 2009.

- "Los administradores", en AA.VV., Comentarios de la Ley de Sociedades de Capital (Dir. BELTRÁN SÁNCHEZ Y ROJO FERNÁNDEZ-RÍO), Ed. Cívitas, Madrid, 2011, pp. 1502-1552.

GARBRAITH, J. K., El nuevo estado Industrial, Ed. Ariel Economía, Barcelona, 1984. 
GARCÍA CAVERO, J., La responsabilidad penal del administrador de hecho de la empresa: Criterios de imputación, Ed. Bosch, Barcelona, 1999.

GARCÍA CHAMÓN, E. Y SOLER PASCUAL, E., "Deberes de los administradores", en AA.VV., Órganos de la sociedad de capital (Dir. GIMENO-BAYÓN COBOS Y GARRIDO ESPÁ), Ed. Tirant lo Blanch, Valencia 2008, pp. 742-796.

GARCÍA-CRUCES GONZÁLEZ, J. A., “Administradores sociales y administrador de hecho”, en Estudios jurídicos en homenaje al Profesor Sánchez de Andrés, Ed. Cívitas, Madrid, 1988, pp. 7-15.

- "La responsabilidad de los administradores por no promoción remoción de la disolución de la sociedad: consideraciones en torno al debate jurisprudencial", en AA.VV., La Responsabilidad de los administradores de las sociedades de capital (Coord. GALÁN CORONA Y GARCÍA-CRUCES GONZÁLEZ), Ed. Tecnos, Madrid, 1999, pp. 48-89.

- "El problema de la represión de la conducta del deudor común", en AA.VV., La reforma de la Legislación Concursal (Dir. ROJO FERNÁNDEZ-RÍO), Ed. Marcial Pons, Madrid, 2003, pp. 248319.

- La calificación del concurso, Ed. Aranzadi, Pamplona, 2004.

- "Declaración de concurso y administradores de la persona jurídica concursada", en AAVV, Estudios en Homenaje al Prof. Albaladejo, v. I, Murcia, 2004, pp. 1969 y ss.

- “Acumulación y coordinación de acciones de responsabilidad de los administradores de un apersona jurídica en concurso (sobre inserción de la llamada responsabilidad concursal en el régimen general de responsabilidad de administradores", $A C$, núm. 18, 2004, www.westlaw.es.

- Las claves de la Ley concursal, Ed. Aranzadi, Cizur Menor, Navarra, 2005.

- "Concursado, cómplice y personas afectadas por la calificación”, en AA.VV., Estudios sobre la ley Concursal. Libro Homenaje a D. Manuel Olivencia, t. V, Ed. Marcial Pons, Madrid, 2005, pp. 49134946.

- "Administradores sociales y administradores de hecho", en AA.VV., Estudios de Derecho mercantil en memoria del Profesor Aníbal Sánchez Andrés, (Coord. SÁENZ GARCÍA DE ALBIZU, OLEO BANET Y MARTÍNEZ FLORA), Ed. Thomson Reuters, Madrid, 2010, pp. 527-561.

- "La calificación del concurso tras la reforma de la ley concursal", en Estudios en homenaje al profesor Dr. Vicent Chuliá, Ed. Tirant Lo Blanch, Valencia, 2013.

- "Disposiciones generales sobre las sociedades mercantiles", en AA.VV., Hacia un nuevo Código Mercantil (Coord. BERCOVITZ RODRÍGUEZ-CANO), Ed. Thomson Reuters Aranzadi, Cizur Menor, 2014, pp. 139-165. 
- "Responsabilidad concursal", en AA.VV., La responsabilidad de los administradores de las sociedades de capital (Coord. GALÁN CORONA Y GARCÍA CRUCES-GONZÁLEZ), Ed, Tecnos, Madrid, 1999, pp. 355-436.

GARCÍA DE ENTERRIA, J., "Los pactos de indemnización del administrador cesado", RDM, 1995, pp. 473 y ss.

- “Los delitos societarios: en su enfoque mercantil”, Ed. Cívitas, Madrid, 1996.

- "La sociedad anónima: la acción en general", Curso de Derecho mercantil, I, Empresario, establecimiento mercantil y actividad empresarial. Derecho de competencia y de la propiedad industrial e intelectual, derecho de sociedades, Ed. Cívitas, Madrid, 1999.

- "Los deberes de conducta de los administradores. Deber de diligencia y lealtad", en AA.VV., La reforma de la Ley de sociedades de capital en materia de gobierno corporativo (Dir. GARCÍA DE ENTERRÍA), Ed. Thomson Reuters- Aranzadi, Cizur Menor, 2015, pp. 61-79.

- "La composición del consejo: La función de los consejeros ejecutivos y dominicales (art. 529 duodecies, apartados. 1, 2,3 y 6 LSC)", en AA.VV., Junta general y consejo de administración en la sociedad cotizada (Coord. RONCERO SÁNCHEZ), t. II, Ed. Aranzadi, Cizur Menor, 2015, pp. 955986.

- "Responsabilidad concursal", en AA.VV., La responsabilidad de los administradores de las sociedades mercantiles (Dir. ROJO FERNÁNDEZ-RÍO Y BELTRÁN SÁNCHEZ), Ed. Tirant Lo Blanch, Valencia, 2016, pp. 355-436.

GARCÍA MANDALDONIZ, M., "Inconcreción del deber de diligente administración, disposición del régimen de responsabilidad e inclusión de la regla de la discrecionalidad empresarial (artículos 225 y 226 de la Ley de Sociedades de Capital", en AA.VV., Gobierno corporativo: la estructura del órgano de gobierno y la responsabilidad de los administradores" (Dir. MARTÍNEZ-ECHEVARRÍA Y GARCÍA DUEÑAS), Ed. Thomson Reuters Aranzadi, Cizur Menor, 2015, pp. 355-410.

GARCÍA PÉREZ, J. J., "La responsabilidad penal de los administradores de sociedades por impedimento o negativa del ejercicio de los derechos del socio y del ejercicio de la supervisora e inspectora de la Administración”, en AA.VV., La responsabilidad de los administradores de las sociedades de capital (Coord. GALÁN CORONA Y GARCÍA-CRUCES GONZÁLEZ), Ed. Tecnos, Madrid, 1999, pp. 145-199.

GARCÍA RENEDO, C., "Las nuevas competencias de la junta general y la intervención de ésta en asuntos de gestión" en AA.VV., La reforma de la ley de sociedades de capital en materia de gobierno corporativo (Dir. GARCIA DE ENTERRÍA), Ed. Thomson Reuters Aranzadi, Cizur Menor, 2015, pp. 17- 37. 
GARCÍA VILlAVERDE, R., "Capital mínimo”, en Derecho de Sociedades Anónimas, T. I, La fundación, Madrid, 1991.

- "Exoneración de responsabilidad civil de los administradores de la sociedad anónima y la sociedad limitada por falta de culpa (art. 133.2 LSA)", en AA.VV., Derecho de Sociedades. Libro homenaje a Fernando Sánchez Calero, v. II, Ed. McGraw Hill, Madrid, 2002, pp. 1321 y ss.

GARRETA SUCH, J. M., La Diligencia y responsabilidad de los administradores y la contabilidad, Ed. Jurídicas y Sociales, Madrid, 2014.

GARRIDO DE PALMA, V. M., "La operación de acordeón y la sociedad anónima", RJE, La Ley, 1992-4, pp. 1107-1112.

- "La empresa familiar; su gobierno corporativo", en AA.VV., Gobierno corporativo: la estructura del órgano de gobierno y la responsabilidad de los administradores" (Dir. MARTÍNEZ ECHEVARRÍA Y GARCÍA DUEÑAS), Ed. Thomson Reuters Aranzadi, Cizur Menor, 2015, pp. 1009-1038.

- "Protocolos y pautas de actuación de los administradores", en AA.VV., Régimen de deberes, Régimen de deberes y responsabilidad de los administradores en las sociedades de capital (Coord. HERNANDO CEBRIÁ), Ed. Bosch, Barcelona, 2015., pp. 236 y ss.

GARRÍGUES DÍAZ-CAÑAVATE, J., Curso de Derecho mercantil, Madrid, 1936.

- Tratado de Derecho Mercantil, t. I, vol. 2, Madrid, 1947.

GARRÍGUES DÍAZ-CAÑAVATE, J. Y URÍA GONZÁLEZ, R., Comentarios a la ley de sociedades anónimas, t. II, Instituto de estudios políticos, Madrid, 1953.

- Comentarios a la ley de sociedades anónimas. Revisada y puesta al día por MENÉNDEZ Y OLIVENCIA, t. II, $3^{\text {a }}$. Ed. Cívitas, Madrid, 1976.

GIMENO-BAYÓN COBOS, R. Y ORELLANA CANO; N., "La responsabilidad de los administradores (I). Comentarios al artículo 133 de la ley de Sociedades Anónimas", en AA.VV., Órganos de la sociedad de capital (Dir. GIMENO-BAYÓN COBOS Y GARRIDO ESPA), Ed. Tirant lo Blanch, Valencia, 2008. pp. 934-1002

GIRGADO PERANDONES, P., La empresa del grupo y el Derecho de Sociedades, Granada, 2001.

- La responsabilidad de la sociedad matriz y de los administradores de una empresa de grupo, Ed. Marcial Pons, Madrid, 2002.

- "La responsabilidad de la matriz de una empresa de grupo por las deudas de sus filiales en Derecho Español. Situación legislativa y actuación de los tribunales”, RDM, núm. 247, enero-marzo. 2003, pp. 116 y ss.

GIRÓN TENA, J., Derecho de sociedades anónimas, Valladolid, 1951. 
- "La responsabilidad de los administradores de la sociedad anónima, en el derecho español", $A D C$, abril-junio, 1959, pp. 419 y ss.

- "Las reformas varias, pendientes y andantes de la sociedad anónima en España", La Ley, núm. 1, 1989, p. 924 y ss.

GONZÁLEZ CABRERA, I., "Primeras reflexiones sobre responsabilidad de los administradores sociales en la propuesta de código mercantil”, $R d S$, núm. 41, 2013, pp. 331-339.

GOWER, D., Principles of modern Company Law, Ed.8ª Ed. Thompson, Londres, 2016.

GONZÁLEZ SERRANO, L. C., “Administradores sociales y “compliance”; una perspectiva mercantil del cumplimiento penal", en AA.VV., Estudio sobre la responsabilidad de los administradores de las sociedades de capital a la luz de sus recientes reformas legislativas y pronunciamientos judiciales (Dir. DÍAZ MORENO Y VÁZQUEZ CUETO), Ed. Aranzadi, Cizur Menor, 2018, pp. 199-207.

GONZÁLEZ VÁZQUEZ, J.C., "El progresivo reforzamiento de la posición de los accionistas en las sociedades estadounidenses a partir de la "Sarbanes.Oxley Act" de 2002", en AA.VV., Junta General y Consejo de Administración en la sociedad cotizada (Coord. RONCERO SÁNCHEZ), t. II, Ed. Aranzadi, Cizur Menor, 2015, pp. 1341-1393.

GROSSS-BROWNS., "Deberes de administradores en el derecho comparado. El deber de diligencia y el Business Judgment Rule”, RdS, núm. 37, 2011-2012, p. 312.

GRIMALDOS GARCÍA, M. I., "Responsabilidad social corporativa y responsabilidad civil de los administradores", en AA.VV., Responsabilidad social de la empresa y Derecho mercantil (Dir. EMBID IRUJO), Ed. Comares, Murcia, 2010, pp. 155-176.

- "Los administradores. Estatuto jurídico común”, en AA.VV., Introducción al derecho de sociedades de capital. Estudio de la ley de sociedades de capital y legislación complementaria, (Dir. EMBID IRUJO), Ed. Marcial Pons, Ediciones Jurídicas y Sociales, Madrid, 2013, pp. 232-273.

- "Presupuestos y extensión subjetiva de la responsabilidad. Solidaria: artículos 236 y 237. Otras acciones por infracción del deber de lealtad: artículos 227.2 y 232”, en AA.VV., Régimen de deberes y responsabilidad de los administradores en las sociedades de capital (Coord. HERNANDO CEBRIÁ), Ed. Bosch, Barcelona, 2015, pp. 307-358.

- "La acción individual de responsabilidad contra los administradores de las sociedades de capital. Por fin una solución legislativa sobre su régimen jurídico". en AA.VV., Derecho de sociedades, Revisando el derecho de sociedades de capital (Coord. GONZÁLEZ FERNÁNDEZ Y GALACHO ABOLAFIO), Ed. Tirant Lo Blanch, Valencia, 2018., pp. 1295-1313.

GUERRA MARTÍN, G., "El gobierno de las sociedades estadounidense. Su influencia en el movimiento de reforma del Derecho Europeo”, RdS, núm.20, Ed. Aranzadi 2003, p. 197. 
- "La aplicación analógica a las cajas de ahorro del derecho de sociedades anónimas en relación al derecho de información de los consejeros", RdS, núm.24, Madrid, 2005-1, pp. 277-295.

- "La posición jurídica de los administradores de sociedades de capital", en AA.VV., La responsabilidad de los administradores de sociedades de capital (Coord. GUERRA MARTÍN), Ed. La Ley, Madrid, 2011, pp. 39-83.

- "Las políticas societarias como facultades indelegables del consejo de administración. Y, en particular, Las políticas sobre definición de la estructura y gobierno del grupo y sobre gobierno corporativo de la sociedad (arts. 249 bis b) y 529 ter.1.c), e) y g) LSC)" en AA.VV., Junta General y Consejo de administración en la sociedad cotizada (Coord. RONCERO SÁNCHEZ), t. II, Ed. Aranzadi, Cizur Menor, 2015, pp. 1250-1288.

GUERRA MARTÍNEZ, A., "La cuestionada deseabilidad económica de la business judgment rule en Derecho español", Working Paper Series, Facultad de derecho de la universidad CEU San Pablo, 2014, pp. 5-8.

GUERRERO LEBRÓN, Ma . J. Y GÓMEZ PORRÚA, J. M., "La responsabilidad de los administradores de las sociedades de capital en situación concursal", en Estudios sobre la Ley Concursal. Libro Homenaje a Manuel Olivencia, II, Madrid, 2005, pp. 1965-1988.

GUERRERO TREVIJANO, C., El deber de diligencia de los administradores en el gobierno de las sociedades de capital, Ed. Thomson Reuters, Cizur Menor, 2014.

- "La retribución de los consejeros ejecutivos en sociedades cerradas", en AA.VV., Estudios sobre órganos de las sociedades de capital”, (Coord. JUSTE MENCÍA Y ESPÍN GUTIÉRREZ), v. I, Ed. Aranzadi, Cizur Menor, 2017, pp. 975-996.

GUTIÉRREZ RODRÍGUEZ, M., "La responsabilidad penal de los administradores", en AA.VV., La responsabilidad de los administradores de las sociedades mercantiles (Dir. ROJO FERNÁDEZ-RÍO Y BELTRÁN SÁNCHEZ), Ed. Marcial Pons, Madrid, 2016, pp. 445-509.

HERNÁNDEZ MARTÍNEZ, W. D., "Los supuestos de aplicación del administrador de hecho: un análisis del caso español a propósito de la sociedad por acciones simplificada", en Estudio SocioJurídico, Bogotá, Colombia, 14(2), 149-196, julio diciembre de 2012.

HERNÁNDEZ PEÑASCO, R., "Particularidades en el régimen especial del gobierno de las grandes corporaciones y de la responsabilidad de los administradores: supuestos específicos", en AA.VV., Gobierno corporativo: la estructura del órgano de gobierno y la responsabilidad de los administradores (Dir. MARTÍNEZ-ECHEVARRÍA Y GARCÍA DUEÑAS), Ed. Thomson Reuters Aranzadi, Cizur Menor, 2015, pp. 905-948.

HERNÁNDEZ SÁINZ, E., La administración de sociedades de capital por personas jurídicas: régimen jurídico y responsabilidad, Ed. Cizur Menor, Madrid, 2014. 
HERNANDO CEBRÍA, L., El deber de diligente administración en el marco de los deberes de los administradores sociales. La Regla del buen juicio empresarial, Ed. Marcial Pons, Madrid, 2009.

- "La configuración estatutaria del deber de diligente administración", $R d S$, núm. 34, 2010, pp. 125 y ss.

- "El deber general de diligencia. Artículo 225”, en AA.VV., Régimen de deberes y responsabilidad de los administradores en las sociedades de capital (Coord. HERNANDO CEBRIÁ), Ed. Bosch, Barcelona, 2015, pp. 59-98.

- "Presupuestos del deber de lealtad: artículo 227.1", en AA.VV., Régimen de deberes y responsabilidad de los administradores en las sociedades de capital (Coord. HERNANDO CEBRÍA), Ed. Bosch, Barcelona, 2015, pp. 137-186.

HIERRO ANIBARRO, S., El origen de la sociedad anónima en España. Ed. Tecnos, Madrid, 1998.

- "Gobierno corporativo sin mercado de valores", en AA.VV., Gobierno corporativo en sociedades no cotizadas (Dir. HIERRO ANIBARRO), Ed. Marcial Pons, Madrid 2014, pp. 17-35.

HUERTAS VIESCA, Ma . I., "Acción social de responsabilidad de los administradores por los socios y desistimiento (Comentario a la STS, 1ª 30/117200)”, RDM, núm. 243, 2002 pp. 295 y ss.

HURTADO COBLES, J., La doctrina del Levantamiento del velo societario en España e Hispanoamérica, Ed. Atelier, 2008.

IBARREN BLANCO, M., El seguro de responsabilidad civil de los administradores y altos directivos de las sociedades de capital, Ed. Thomson Cívitas, Cizur Menor, 2005.

IGLESIAS PRADA, J. L., Administración y delegación de facultades en la sociedad anónima, Ed. Tecnos, Madrid, 1971.

ILLESCAS ORTÍZ, R., "Creciente tipificación de las funciones de los administradores de las sociedades anónimas", en AA.VV., Estudios sobre órganos de las sociedades de capital (Coord. JUSTE MENCÍA Y ESPÍN GUTIÉRREZ) v. I, Ed. Aranzadi, Cizur Menor, 2017, pp. 898-913.

ITURMENDI, G., "La responsabilidad de los administradores en la Sociedad Anónima”, en Revista Española de Seguros, núm. 64, 1990.

JORDANO FRAGA, F., La responsabilidad contractual, Ed. Cívitas, Madrid 1987.

JUSTE MENCIA, J., "En torno a la aplicación del régimen de responsabilidad de los administradores al apoderado general de las Sociedades. Notas a las SSTS de 26 de junio de 1998, 7 de junio de 1999 y de la AP de Valencia de 27 de septiembre de 1999”, $R d S$, núm. 12, 2001, I, pp. 444 y ss. 
- "Limitaciones al poder de representación del factor en el giro o tráfico del establecimiento. Actuación del administrador societario en calidad de factor", en AA.VV., Derecho de Sociedades. Libro Homenaje a Fernando Sánchez Calero, vol. II, Ed. MacGraw Hill, Madrid 2002, pp. 1351 y ss.

- Factor de comercio, gerente de empresa, director general (estudio jurídico mercantil, Ed. Publicación del Real Colegio de España, Bolonia, 2003.

- "En torno a la aplicación del régimen de la responsabilidad de los administradores al apoderado general de la sociedad", $R d S$, núm. 24, 2005, pp. 448-450.

- "Deberes de los administradores”, $R d S$, núm. 25, 2005, pp. 75 y ss.

- "Legitimación subsidiaria para el ejercicio de la acción social", en AA.VV., La responsabilidad de los administradores (Dir. ROJO FERNÁNDEZ-RÍO Y BELTRÁN SÁNCHEZ), Ed. Tirant lo Blanch, Valencia, 2005, pp. 115-148.

- "Régimen de imperatividad y dispensa", en AA.VV., Comentario de la reforma del régimen de las sociedades de capital en materia de gobierno corporativo (Ley 31/2014), (Coord. JUSTE MENCÍA), Ed. Thomson Reuters, Cizur Menor, 2015, pp. 414-422.

- "Responsabilidad de los administradores", en AA.VV., Comentarios de la reforma del régimen de las sociedades de capital en materia de gobierno corporativo (Ley 31/2014), (Coord. JUSTE MENCÍA), Ed. Thomson Reuters, Cizur Menor, 2015, p. 459.

- "Artículo 227. Deber de lealtad", en AA.VV., Comentarios de la reforma del régimen de las sociedades de capital en materia de gobierno corporativo (Ley 31/2014), (Coord. JUSTE MENCÍA), Ed. Thomson Reuters, Cizur Menor, 2015, pp. 361-373.

- "Articulo 236. Presupuestos y extensión de la responsabilidad", en AA.VV., Comentarios de la reforma del régimen de las sociedades de capital en materia de gobierno corporativo (Ley 31/2014), (Coord. JUSTE MENCÍA Y ESPÍN GUTIÉRREZ), Ed. Thomson Reuters, Cizur Menor, 2015, pp. 444-487.

- "Algunas reflexiones sobre las instrucciones de la junta en materia de gestión y la responsabilidad de los administradores", en AA.VV., Estudios sobre órganos de las sociedades de capital, (Coord. JUSTE MENCÍA Y ESPÍN GUTIÉRREZ), v. I, Ed. Aranzadi, Cizur Menor, 2017., pp. 395-415, pp. 403-410.

JUSTE MENCÍA, F. Y IGARTUA ARREGUI, J., "Deberes de los administradores (reforma de la LSA por la Ley de Transparencia)", $R d S$, núm. 24, 2005, pp. 75-89.

LACRUZ BERDEJO, J. L., Elementos de Derecho Civil, t. I (Parte General), vol. II. Ed. $4^{\text {a }(r e v i s a d a ~ y ~}$ puesta al día por Delgado Echeverría) Ed. Dykinson, 2004.

LANGLE, E Y RUBIO, E., Manual de Derecho mercantil español, t. I, Ed. Bosch, Barcelona, 1950. 
LARGO GIL, R., Y HERNÁNDEZ SAÍNZ, E., "La imputación de responsabilidad civil en el seno de los grupos de sociedades", en AA.VV., Descentralización productiva y responsabilidades empresariales. El “outsourcing” (Dir. RIVERO LAMAS), Ed. Aranzadi, Pamplona, 2003, p. 432.

LATORRE CHINER, N., "El concepto de administrador de hecho en el nuevo artículo 133.2 LSA", RDM, núm. 253, 2004, pp. 853- 899.

- "Administrador de hecho y apoderado general (Comentario a la STS de 8 de febrero de 2008 (RJ 2664/ 2008)", $R d S$, núm. 32, 2009, pp. 389-398.

- “El apoderado general en la Ley Concursal”, RCDP, núm. 19, 2013, pp. 65-80.

LAVILLA RUBIRA, J. J., “Órgano”, en Enc. Jur. Básica, Madrid, 1995.

LECIÑENA MENDIZABAL, E., "La responsabilidad del administrador que autocontrata en conflicto en las sociedades de capital y su equivalencia con la respuesta normativa a la auto entrada en un negocio en conflicto del patrono en las fundaciones", en AA.VV., Derecho de sociedades, Revisando el derecho de sociedades de capital (Coord. GONZÁLEZ FERNÁNDEZ Y GALACHO ABOLAFIO), Ed. Tirant Lo Blanch, Valencia, 2018, pp. 1342-1365.

LEFÉBVRE, F., Administradores y directivos. Dossier Práctico, Ed. Francis Lefébre, Madrid 20142015.

LEVENEUR, L., "Situations de fait et droit privé, bibliothéque de droit privé", Libraire generale de Droit et de Jurisprudence, París, 1990.

LLEBOT MAJÓ, J. O., “El sistema de la responsabilidad de los administradores”, $R d S$, 1996, pp. 5160.

- “La responsabilidad concursal de los administradores", en RGD, núm. 657, 1999, pp. 179-189.

- "Deberes y responsabilidad de los administradores", en AA.VV., La responsabilidad de los administradores de las sociedades mercantiles (Dir. ROJO BELTRÁN), Ed. Tirant Lo Blanch, Valencia 2012, pp. 21-40.

- "El deber general de diligencia (art. 225.1 LSC)", en AA.VV., Junta General y Consejo de administración en la sociedad cotizada (Coord. RONCERO SÁNCHEZ), t. II, Ed. Aranzadi, Cizur Menor, 2015, pp. 317-344.

- "Los deberes y responsabilidad de los administradores", en AA.VV., La responsabilidad de los administradores de las sociedades mercantiles (Dir. ROJO FERNÁNDEZ-RÍO Y BELTRÁN SÁNCHEZ). Ed. Tirant lo Blanch, Valencia, 2016, pp. 21-61.

LÓPEZ CAPELLA, E., "Búsqueda de indicio para la prueba del administrador de hecho", en Probática, Coord. Instituto de Probática y derecho probatorio de la facultad de derecho ESDE-URl, Iuris, marzo, 2012, pp. 31. 
LÓPEZ DE MEDRANO SAAVEDRA, F., La separación de los administradores en la sociedad anónima, Barcelona, 1986.

LÓPEZ QUESADA MARTÍN, E. Y CAMACHO MIÑANO, M., "Códigos de Gobierno suficientes para afrontar la crisis", Contabilidad, núm. 237, noviembre, 2011, p. 52.

LÓPEZ SANTANA, N., "Comentario a la sentencia de la Sala 1 del tribunal supremo de 30 de marzo de 2000", CCJC, núm. 54, octubre-diciembre 2000, p.118.

LOZANO SAIGI, M., “Aproximación jurídica a la figura y régimen de responsabilidad del administrador de hecho", RJC, núm. 4, 2005, p. 88.

LUTTER, M., "Die Business Judgment Rule und ihre pratische anwendung” en ZIP, núm. 18, 2007, p. 846.

MACHADO PLAZAS, J., Perdida del capital social y responsabilidad de los administradores por deudas sociales, Ed. Cívitas, Madrid, 1997.

- El concurso de los acreedores culpable. Calificación y responsabilidad concursal, Ed. Thomson Cívitas, Navarra, 2006.

MACÍAS CASTILlO, A. Y JUEGA CUESTA, R., Ley Concursal Comentada, Ed. El Derecho, Madrid, 2014.

MAGRO SERVET, V., "Persecución Penal de los ilícitos cometidos por los administradores de hecho", La Ley, núm. 6541, 4 de septiembre de 2006, pp. 1-7.

MAMBRILLA RIVERA, V. Y QUIJANO GONZÁLEZ, I., "Los deberes fiduciarios de diligencia y lealtad. En particular los conflictos de interés y operaciones vinculadas" en AA.VV., Derecho de sociedades anónimas cotizadas (estructura de gobierno y mercados), (Coord. RODRÍGUEZ ARTIGAS), v. II., 2006, pp. 915-990.

- "Las concretas manifestaciones del deber de diligencia de los administradores" en AA.VV., Junta general y Consejo de administración en la sociedad cotizada (Coord. RONCERO SÁNCHEZ), t. II, Ed. Aranzadi, Cizur Menor, 2015, pp. 345-381.

MARÍN DE LA BÁRCENA GARCÍA MARTÍN, F., "La acción individual de responsabilidad de los administradores de sociedad anónima frente a socios y terceros”, en $R d S$ núm.13, 1999, pág. 304 y ss.

- "Deberes y responsabilidad de los administradores ante la insolvencia de las sociedades de capital", $R d S$, núm. 24, 2000, pp. 91 y ss.

- "Responsabilidad de los administradores de sociedades de capital por no promoción de la disolución o el concurso (sobre retroactividad de la reforma de los arts. 265.5 LSA y 105.5 LSRL)”, en RdS, núm. 26,2006, pp. 455 y ss.

- "Responsabilidad concursal”, ADC, núm. 28, 2013. 
MARINA GARCÍA-TUÑON, A., Gobierno corporativo información económica y registro mercantil, Ed. Colegio de Registradores de la Propiedad y Mercantiles de España, Madrid, 2007.

- "Junta general y concurso de acreedores" en AA.VV., Estudios sobre órganos de las sociedades de capital (Coord. JUSTE MENCÍA Y ESPÍN GUTIÉRREZ), v. I, Ed. Aranzadi, Cizur Menor, 2017, pp. 225-264.

MARTÍN REYES, M. A., "La insolvencia de las sociedades de capital y la exigencia de responsabilidad a sus administradores”, RDM, núm. 277, 2010, pp. 835-898.

MARTÍNEZ-ECHEVARRÍA Y GARCÍA DUEÑAS, A., "La defensa del interés social y la titularidad del patrimonio social como elemento determinante del gobierno corporativo", en AA.VV., Gobierno corporativo. La estructura del órgano de gobierno y la responsabilidad de los administradores (Dir. MARTÍNEZ-ECHEVARRÍA Y GARCÍA DUEÑAS), Ed. Thomson Reuters Aranzadi, Cizur Menor, 2015, pp. 95-133.

MARTÍNEZ GUTIÉRREZ, A., "El director general de las sociedades capitalistas. Un estudio multidisciplinar", RDM, núm. 253, 2004, pp. 977-1004.

MARTÍNEZ MACHUCA, P., La protección de los socios externos en los grupos de sociedades, Bolonia, 1999.

MARTÍNEZ MARTÍNEZ, D. F. Y SAÉZ NICOLÁS, J. R., "El deber de diligencia y responsabilidad de los administradores de las sociedades no cotizadas a la luz del art. 31 bis del Código Penal o la obligación de implementar programas de compliance penal” en AA.VV., Derecho de Sociedades Revisando el derecho de sociedades (Coord. OLMEDO PERALTA Y GALACHO ABOLAFIO), Ed. Tirant Lo Blanch, Valencia 2018, pp. 1263- 1284.

MARTÍNEZ ROSADO, J., "La Companies Act" de 2006 y las singularidades en materia de recomendaciones de gobierno corporativo características del Derecho inglés relativas al órgano de administración", en AA.VV., Junta general y Consejo de administración en la sociedad cotizada (Coord. RONCERO SÁNCHEZ), t. II, Ed. Aranzadi, Cizur Menor, 2015, pp. 1257-1288.

MARTÍNEZ SANZ, F., "El administrador de hecho”, en $R d S$, núm. 14, 2001.

- "Régimen interno y delegación de facultades en el conejo de administración de la sociedad anónima", en AA.VV., Derecho de sociedades. Libro Homenaje a Fernando Sánchez Calero, v. II, Ed. McGraw Hill, Madrid, 2002, pp. 1761 y ss.

- "Ámbito subjetivo de la responsabilidad", en AA.VV., La Responsabilidad de los administradores de las sociedades mercantiles (Dir. ROJO FERNÁNDEZ-RÍO Y BELTRÁN SÁNCHEZ), Ed. Tirant lo Blanch, Valencia 2005, pp. 55-77. 
- "La efectividad del control preventivo por parte del Consejo: estrategia de negocios, optimización de recursos, definición de factores de riesgo y estructura de grupo (las políticas corporativas como directrices de gestión)", en AA.VV., Cuaderno de derecho para ingenieros. Hacia un nuevo gobierno corporativo (reforma desde la desconfianza de los mercados), (Coord. ALONSO UREBA), Ed. La Ley, 2013, pp. 31-35.

- "Los administradores responsables", en AA.VV., La responsabilidad de los administradores de las sociedades mercantiles (Dir. ROJO FERNÁNDEZ-RÍO Y BELTRÁN SÁNCHEZ), Ed. Tirant lo Blanch, Valencia, 2005, pp. 65-96.

- "Los administradores responsables" en AA.VV., La responsabilidad de los administradores de las sociedades mercantiles, (Dir. ROJO FERNÁNDEZ-RÍO Y BELTRÁN SÁNCHEZ,), Ed. Tirant lo Blanch, Valencia, 2012, pp. 69 y ss.; y 2013, pp. 55 y ss.

- "Requisitos según la judicatura española para la consideración de la figura del administrador de hecho", Economist \& Jurist, mayo, 2013.

MÁS-GUINDAL GARCÍA, J., "La responsabilidad de los administradores", en AA.VV., Gobierno Corporativo: la estructura del órgano de gobierno y la responsabilidad de los administradores" (Dir. MARTÍNEZ-ECHEVARRÍA Y GARCÍA DUEÑAS), Ed. Thomson Reuters Aranzadi, Cizur Menor, 2015, pp. 785-811.

MASSAGUE FUENTES, J., "La estructura interna de los grupos de sociedades (aspectos jurídicos societarios)", RDM, núm. 192, 1989, p. 281.

MATA MARTÍN, R. M., "La responsabilidad penal del administrador societario desleal. Estudio del delito del artículo 295 del Código Penal”, $R d S$, núm. 12, 1999, pp. 12 y ss.

MATEU DE ROS CEREZO, R., La Ley de Transparencia en Sociedades Cotizadas (Ley 26/2003, de 17 de julio, de Modificación de la Ley del Mercado de Valores y de la Ley de Sociedades Anónimas), Ed. Thompson Aranzadi, Cizur Menor, 2004.

- El Código Unificado de Gobierno Corporativo, Ed. Aranzadi, Madrid, 2007.

- Practica de Gobierno Corporativo; La Reforma de la ley de Sociedades de Capital y del Código de Buen Gobierno, Ed. Thomson Reuters Aranzadi, Cizur Menor, 2015.

MELCHOR GIMÉNEZ, E., "La acción individual de responsabilidad como vía para el resarcimiento del socio perjudicado por el tipo de canje en la fusión: análisis de sus presupuestos", en AA.VV., Estudios de la responsabilidad de los administradores a la luz de sus recientes reformas legislativas y pronunciamientos judiciales, (Dir. DÍAZ MORENO Y VÁZQUEZ CUETO), Ed. Aranzadi, Cizur Menor, 2018, pp. 239-251. 
MERCADAL VIDAL, F., "El acreedor financiero como administrador de hecho. Especial referencia a los covenants", ADCcon, núm. 36, pp. 115-128.

MESÍA MARTÍNEZ, C., "El procedimiento de denuncia interna o whistleblowing en los códigos de conducta", en AA.VV., Gobierno corporativo: la estructura del órgano de gobierno y la responsabilidad de los administradores" (Dir. MARTÍNEZ-ECHEVARRÍA Y GARCÍA DUEÑAS), Ed. Thomson Reuters Aranzadi, Cizur Menor, 2015, pp. 1208-1249.

MILÁNS DEL BOSCH PORTOLES, I. Y UNCETA LABORDA, M., "La configuración y la estructura de los órganos de gobierno de las corporaciones", en AA.VV., Gobierno Corporativo: la estructura del órgano de gobierno y la responsabilidad de los administradores (Dir. MARTÍNEZECHEVARRÍA Y GARCÍA DUEÑAS), Ed. Thomson Reuters Aranzadi, Cizur Menor, 2015, pp. 163201.

MINERVINI, G., Gli amministratori di società per azioni. Ed. Giuffrè. Milano, 1956.

MÍNGUEZ SANZ, S., “Comentario a la RDGRN de 11 de marzo de 1999”, RCDI, núm. 612, 1992, p. 2203.

MONTÉS PÉNADES, V., “Art.7.1 CC”, Comentarios a las reformas del CC, t.1, Ed. Tecnos, Madrid, 1977, pp. 356-371.

MORA MATEO, J. E., "Responsabilidad Civil del administrador de la sociedad anónima", $R G D$, núm. 591, diciembre, 1993, pp. 1849- 1865.

MORENO BUENDÍA, F. J., "El contenido del acuerdo social de ejercicio de la acción social de responsabilidad. Especial referencia al ámbito subjetivo", en AA.VV., Estudio sobre la responsabilidad de los administradores de las sociedades de capital a la luz de sus recientes reformas legislativas y pronunciamientos judiciales (Dir. DÍAZ MORENO Y VÁZQUEZ CUETO), Ed. Aranzadi, Cizur Menor, 2018, pp. 267-284.

MORENO SERRANO, E., Los administradores de una sociedad de capital ante una situación de insolvencia, Ed. La Ley, Madrid, 2015.

- "La responsabilidad de la sociedad matriz como administrador de hecho", en AA.VV., Derecho de Sociedades, Revisando el derecho de sociedades de capital (Coord. GONZÁLEZ FERNÁNDEZ Y GALACHO ABOLAFIO), Ed. Tirant Lo Blanch, Valencia, 2018., pp. 1329-1342.

- "Responsabilidad de la sociedad matriz como administrador de hecho", AA.VV., Estudio sobre la responsabilidad de los administradores de las sociedades de capital a la luz de sus recientes reformas legislativas y pronunciamientos judiciales (Dir. DÍAZ MORENO Y VÁZQUEZ CUETO), Ed. Aranzadi, Cizur Menor, 2018, pp. 253-265. 
MOYA BALLESTER, J., La responsabilidad de los administradores de Sociedades en situaciones de crisis, Ed. La Ley, Madrid, 2010.

MOYA JIMÉNEZ, A., La responsabilidad de los administradores de empresas insolventes (Capitulo II. Aspectos procesales de la acción contra los administradores), Ed. Bosh, Barcelona, 2009.

- La responsabilidad de los administradores de sociedades en situaciones de crisis, Ed. La Ley, Madrid, 2010.

- La responsabilidad de los administradores de empresas insolventes, adaptado a la Ley 25/2011, de 1 de agosto, y la Ley 38/20011, de 10 de octubre, de reforma de la LC y la modificación de la LSC por el RDL 9/2012 de 16 de marzo, que modifica la Ley de sociedades de capital, Ed. Bosch, Barcelona, 2012 .

La responsabilidad de los administradores de empresas insolventes, adaptada a la Ley 14/2013, de 27 de septiembre, de apoyo a los emprendedores y su internalización, Ed. Bosch, Barcelona, 2014.

MOYA REVERTER, J., "Los grupos de sociedades y la protección de los acreedores", $R d S$, 2012-1, p. 309.

MOYA YODI, J. Y RUÍZ RUBIO, M. C., "La naturaleza jurídica especial de la responsabilidad por el déficit a la luz de los criterios de imputación objetiva contenidos en el artículo 172 bis de la Ley concursal”, Aranzadi Insignis, núm. 8, 2012.

MUÑOZ GARCÍA, A., "La disponibilidad $<<$ de lege lata $>>$, el deber de diligencia de los administradores", en AA.VV., Estudios sobre órganos de las sociedades de capital, v. I RdS, Ciur Menor, 2017, pp. 1023-1046.

MUÑOZ MARTÍN, N., "Perdidas de las sociedades de Responsabilidad limitada", en Estudios de derecho Mercantil, Homenaje al profesor Justino Fernández Duque, Valladolid, 1998, pp. 513 y ss.

MUÑOZ PAREDES, J. M., La información de los consejeros en la Sociedad Anónima, Ed. Aranzadi, Pamplona, 1999.

- "El derecho de información de los administradores tras la Ley de transparencia", Diario La Ley, núm. 6078, 2004.

- La ley de transparencia de las sociedades anónimas cotizadas, Pamplona, 2004.

- Tratado judicial de la responsabilidad de los administradores, Ed. Aranzadi, Cizur Menor, 2005.

NEILA NEILA, J. M., "Los procedimientos judiciales en la nueva Ley de Sociedades Anónimas", RDP, Madrid, 1992, pp. 1418-1419.

NICOLÁS BERNAD, J. A, La responsabilidad de los administradores de la sociedad de capital en la cotización a la seguridad social, Ed. Aranzadi, Navarra, 2014. 
NIETO DELGADO, C., “¿Puede la banca ser calificada como administrador de hecho tras una refinanciación?”, ADConc, núm. 40, 2017, pp. 179-196.

NIETO MARTÍN, A., Problemas fundamentales del cumplimiento normativo en el derecho penal. Compliance y teoría del derecho penal, Ed. Marcial Pons, Valencia 2003.

OLIVARES JAMES, J.M., "En torno a los administradores de hecho en la SA", en Anales de la Academia Matritense y del Notariado, 1978, pp. 446 y ss.

OLIVENCIA RUÍZ, M., "El buen gobierno de las sociedades y su evolución”, en AA.VV., Tendencias actuales en la ordenación del control y el capital en las sociedades mercantiles (Dir. LEÓN SANZ), Ed. Marcial Pons, 2009, pp. 11-64.

- "El consejo coordinador", en AA.VV., Estudios sobre órganos de las sociedades de capital, (Coord. JUSTE MENCÍA Y ESPÍN GUTIÉRREZ), v. II, Aranzadi, Cizur Menor, 2017, pp. 336-340.

- "Delimitación de la materia mercantil", en AA.VV., Hacia un nuevo Código Mercantil, (Coord. BERCOVITZ RODRÍGUEZ-CANO), Ed. Thomson Reuters Aranzadi, Cizur Menor, 2014, pp. 57-67.

- "El Consejo coordinador", en AA.VV., Estudios sobre órganos de las sociedades de capital (Coord. JUSTE MENCÍA Y ESPÍN GUTIÉRREZ), v. II, Ed. Aranzadi, Cizur Menor, 2017, pp. 336-351.

ORTUÑO BAEZA, M.T., Reducción de capital en la Sociedad Anónima, Ed. Aranzadi, Cizur Menor, Navarra 2004, pp. 194 y 195.

OTOXA-ERRARTE COIKOETXEA, R., "La responsabilidad de los socios por la infracapitalizacion de la sociedad", $R d S$, núm. 34, pp. 91-104.

PABLO-ROMERO GIL-DELGADO, M. C., "Responsabilidad de los administradores de sociedades por no haber instado el concurso ¿supuesto asegurable?”, $R d S$, núm. 26, 2006, pp. 311-332.

PARDO PARDO, J. M ${ }^{\mathrm{a}}$., El nuevo régimen de responsabilidad de los administradores de empresas en crisis, Ed. Bosch, Barcelona, 2015, pp. 21-25.

PASTOR SEMPERE, C., "Comentarios a la Sentencia del Tribunal Supremo de 24 de febrero de 2014", en AA.VV., Archivo Commenda de jurisprudencia societaria (Dir. EMBID IRUJO), Ed. Comares, Granada 2013/ 2014.

- "Responsabilidad de los administradores", en AA.VV., Archivo Commenda de jurisprudencia societaria (Dir. EMBID IRUJO), Ed. Comares, Granada, 2011/2012, pp. 171-194.

PAZ-ARES RODRÍGUEZ, C., "Sobre la infracapitalización de las sociedades”, $A D C, 1983$, pp. 1587, pp. 1596 y ss.

PAZ-ARES RODRÍGUEZ, C. Y VELASCO CABALLERO, F., Infracciones administrativas y auto cartera, Ed. McGraw Hill, Madrid, 1997. 
- La ley, el mercado y el gobierno corporativo, Ed. Ius et Veritas, 2002.

- "La responsabilidad de los administradores como instrumento de gobierno corporativo", Ed. Indret Working Paper, núm. 162, Barcelona, octubre de 2003. www.indret.com, pp. 17 y ss.

- "La responsabilidad de los administradores como instrumento de gobierno corporativo", $R d S$, núm. 20, 2003, pp. 67 y ss.

- "El gobierno corporativo como estrategia de creación valor", Ed. Indret Working Paper, núm. 182. Barcelona, 2004.

- "Los deberes fiduciarios de diligencia y lealtad", en AA.VV., Derechos de sociedades cotizadas, t II, Ed. Thomson Aranzadi, 2006.

- Responsabilidad de los administradores y gobierno corporativo, Fundación Registral, Madrid, 2007.

- "Anatomía del deber de lealtad", en AA.VV. Junta General y Consejo de administración en la sociedad cotizada (Coord. RONCERO SÁNCHEZ), t. I, Ed. Aranzadi, Cizur Menor, 2015, pp. 425458.

PEINADO GRACÍA, J. I., "Las acciones derivadas de la infracción del deber de lealtad 8 art. 232 LSC)”, en AA.VV., Junta General y Consejo de administración en la sociedad cotizada (Coord. RONCERO SÁNCHEZ), t. II, Ed. Aranzadi, Cizur Menor, 2015, pp. 563-612.

- "Abnegación y silencio en la sociedad mercantil (apuntes sobre los conflictos de interés entre el socio y su sociedad)", en AA.VV., Derecho de sociedades, Revisando el derecho de sociedades de capital (Coord. OLMEDO PERALTA Y GALACHO ABOLAFIO), Ed. Tirant Lo Blanch, Valencia, 2018, pp. 43-78.

PENNISI, G., "Administratore de facto e Shadow director en el sistema giurídico inglese: quache spunto comparatistico", Revista La società, núm. 2, 2004, pp. 252-255.

PERDICES HUETOS, A., "Significado actual de los administradores de hecho: los que administran de hecho y los que de hecho administran. A propósito de la STS de 24 de septiembre 2001 (RJ 2001, 7489)”, RdS, núm. 18, 2002, pp. 277-287.

- "Los riesgos de la colegiación como principio legal de funcionamiento y estructuración del consejo de administración", en AA.VV., Cuaderno de derecho para ingenieros. Hacia un nuevo gobierno corporativo (reforma desde la desconfianza de los mercados) (Coord. ALONSO UREBA), Ed. La Ley, Madrid, 2013, pp. 49-62.

PÉREZ DE LA CRUZ DE OÑA, C., "Financiación de proyectos. La contratación bancaria", Vlex. Id. 39087168 , octubre 2007.

PÉREZ ESCOLAR, R., "Los administradores de hecho y su actuación en el tráfico”, RDM, núm. 108, 1968 , pp. 339 y ss. 
PEROCHON, F., Entresprisess en difficulté. Instruments de crédit et paiment, París, 2006.

PETIT CALVO, C., "El anonimato de la sociedad mercantil y la llamada responsabilidad limitada. Apuntes para la historia de las anónimas en el derecho español del siglo XX", en AA.VV., Tendencias actuales en la ordenación de control y el capital en las sociedades mercantiles" (Coord. LEÓN SANZ), Ed. Marcial Pons, Madrid 2009, pp. 77-91.

PINTO, A., Y VISENTINI, G., The Legal Bsis of Corporate Governace in Publicly held corporations, Ed. Kluwer Law, Cambridge, 1998.

POLO SÁNCHEZ, E., "Los administradores y el consejo de administración de la sociedad anónima (arts.123 a 143 de la LSA)" en AA.VV., Comentario al régimen legal de las sociedades mercantiles, t. VI (Dir. URÍA, MENÉNDEZ Y OLIVENCIA), Ed. Cívitas, Madrid, 1992, pp. 21-58.

- "Abuso o tiranía. Reflexiones sobre la dialéctica entre mayoría y minoría en la sociedad anónima”, en Estudios jurídicos en Homenaje al profesor E. Menéndez, t. II, (Coord. IGLESIAS PRADA), Ed. Cívitas, Madrid, 1996, pp. 2269-2292.

- "El ejercicio del cargo de administrador de la sociedad anónima por personas jurídicas", $R D M$, núm. 98, 2001.

PORFIRIO CAPRIO, L. J., "Administradores de hecho y concurso: da mihi factum, dabo tibi ius", Revista de la facultad de derecho de la UNED, 2011, pp. 5 y ss.

PORTELLANO DÍEZ, P., "El deber de evitar situaciones de conflicto de interés: entre la imperativa y la dispensa (arts. 229, 230 y 529 ter.1.h) LSC", en AA.VV., Junta general y Consejo de Administración en la sociedad cotizada (Coord. RONCERO SÁNCHEZ), t. II, Ed. Aranzadi, Cizur Menor, 2015, pp. 459-476.

PRADA GONZÁLEZ, J. M., "La persona jurídica administradora de una sociedad anónima", en Estudios jurídicos en homenaje al Profesor Aurelio Menéndez, t. II, Ed. Cívitas, Madrid, 1996, pp. 2295 y ss.

PRADES CUTILLAS, D., “Administradores de hecho: tipologías no tan encubiertas”, La Ley, 6 de mayo de 2009, pp. 5-11.

PRESTI, G., "Le raccomendazioni conso nella cornice della corporate governance", Revista La Società, 1997, pp. 739 y ss.

PULGAR EZQUERRA, J., “Artículo 2, presupuesto objetivo", en AA.VV., Comentarios a la Ley Concursal (Coord. FERNÁNDEZ DE LA GÁNDARA Y SÁNCHEZ ÁLVAREZ), t. I, Ed. Marcial Pons, Madrid, 2004, pp. 86 y ss. 
- La responsabilidad de las entidades financieras por concesión abusiva de crédito en derecho español, tendencias actuales en torno al mercado de crédito, Ed. Marcial Pons, Madrid, Barcelona, Buenos Aires, 2010.

PUY FERNÁNDEZ, G., "La responsabilidad social en el marco del gobierno corporativo", en AA.VV., Tendencias actuales en la ordenación y control y el capital en las sociedades mercantiles (Coord. LEÓN SANZ), Ed. Marcial Pons, Madrid, 2009, pp. 193-207.

PUYOL MARTÍNEZ-FERRANDO, B., "La exoneración de responsabilidad de los administradores de sociedades por intervención de la junta general”, en AA.VV., Estudios de derecho de sociedades y derecho concursal, Libro homenaje al Prof. García Villaverde, tomo II, Ed. Marcial Pons, Madrid, 2007, pp. 1021-1058.

QUIJANO GONZÁLEZ, J., La responsabilidad civil de los administradores de la Sociedad Anónima, Valladolid, 1985.

- "La responsabilidad de los administradores por no disolución de la sociedad: Art. 262.5 TRLSA SAP Burgos de 24 de julio 1995”, RdS, núm. 5, 1995, pp. 265-282.

- "Responsabilidad de los consejeros", en AA.VV., El gobierno de las sociedades cotizadas (Coord. ESTEBAN VELASCO), Ed. Marcial Pons, Madrid, 1999, pp. 537-592.

- "La responsabilidad civil de los administradores por no disolución de la sociedad y las causas de exoneración”, $R d S$, núm. 19, 2020, p. 331 y ss.

- "La responsabilidad concursal tras la Ley 38/2011”, RDCP, núm. 18, 2003.

- "Estatuto de los administradores", $R d S$, núm. 27, 2006, pp. 115 y ss.

- "Los deberes fiduciarios de diligencia y lealtad", en AA.VV., Derechos de sociedades cotizadas, t II, Ed. Thomson-Aranzadi, 2006, pp. 948 y ss.

- "La responsabilidad de los administradores", en AA.VV., Comentarios de la Ley de sociedades de capital (Dir. ROJO FERNÁNDEZ-RÍO Y BELTRÁN SÁNCHEZ), t. 1, Ed. Cívitas, Cizur Menor, 2011, pp. 1691-1698.

- "Responsabilidad de consejeros y directivos. La evolución de la dirección por el consejo de administración", en AA.VV., Cuaderno de derecho para ingenieros. Hacia un nuevo gobierno corporativo (reforma desde la desconfianza de los mercados), (Coord. ALONSO UREBA), Ed. La Ley, Madrid 2013, pp. 81-101.

- "Sociedades mercantiles: disolución; sociedades cotizadas", en AA.VV., Hacia un nuevo Código Mercantil, (Coord. BERCOVITZ RODRÍGUEZ-CANO), Ed. Thomson Reuters Aranzadi, Cizur Menor, 2014, pp. 193-211. 
- "Articulo 236", en AA.VV., Comentarios de la Ley de sociedades de capital (Dir. ROJO FERNÁNDEZ-RÍO Y BELTRÁN SÁNCHEZ), t. 1, Ed. Cívitas, Cizur Menor, 2011, pp. 1700-1707.

- "La responsabilidad concursal tras la Ley 38/2011 de reforma de la Ley Concursal”, RDCP, núm.18, 2013.

- "La acción social de responsabilidad contra los administradores: el acuerdo y legitimación para ejercitarla. Comentario a la sentencia 380/2012, de 5 de diciembre de 2012, de la Audiencia Provincial de Madrid, Sección 28”, RDM, núm. 290, 2013, pp. 347 y ss.

- "Los presupuestos de la responsabilidad de los administradores en el nuevo modelo del Consejo de administración (arts. 236.1 y 2 LSC)", en AA.VV., Junta General y Consejo de administración en la sociedad cotizada (Coord. RONCERO SÁNCHEZ), t. II, Ed. Aranzadi, Cizur Menor, 2015, pp. 591632.

- "Deber de lealtad; régimen de imperatividad y dispensa", en AA.VV., Estudio sobre la responsabilidad de los administradores de las sociedades de capital a la luz de sus recientes reformas legislativas y pronunciamientos judiciales (Dir. DÍAZ MORENO Y VÁZQUEZ CUETO), Ed. Aranzadi, Cizur Menor, 2018, pp. 21-49.

RAGUSA MAGGIORE, G., "Socio tiranno, azionista único e persistenza della personalitá giuridica", Diritto Famillantere Commerciale, 1977, II, pp. 651 y ss.

RAMOS CALVO, M. D., "Derecho de la competencia y deberes de diligencia”, $R d S$, núm. 42, 2014, p. 162.

RAMOS HERRANZ, I., "Prohibición de utilizar el nombre de la sociedad y la condición de administrador para influir indebidamente en operaciones privadas por cuenta propia o realizadas por personas vinculadas (artículo 229.1 b) de la Ley de sociedades de Capital”, en AA.VV., Gobierno Corporativo: la estructura del órgano de gobierno y la responsabilidad de los administradores" (Dir. MARTÍNEZ-ECHEVARRÍA Y GARCÍA DUEÑAS), Ed. Thomson Reuters Aranzadi, Cizur Menor, 2015, pp. 465-507.

RECALDE CASTELLS, A., "Los administradores de las sociedades anónimas en un entorno de buen gobierno", RVEH, núm.6, 2003, pp. 51-77.

- "El fracaso del derecho concursal ya declarado", Anuario de derecho concursal, núm. 30, 2013, p. 160.

- "Artículo 160. Competencia de la Junta", en AA.VV., Comentario de la reforma del régimen de las sociedades de capital en materia de gobierno corporativo (Ley 31/2014), (Coord. JUSTE MENCÍA), Ed. Thomson Reuters, Cizur Menor, 2015, pp. 29-51. 
- "Articulo 161. Intervención de la junta general en asuntos de gestión”, en AA.VV., Comentarios de la reforma del régimen de las sociedades de capital en materia de gobierno corporativo (Ley 31/2014), (Coord. JUSTE MENCÍA), Ed. Thomson Reuters, Cizur Menor, 2015, pp. 51-59.

- "Los administradores de las sociedades anónimas en un entorno de buen gobierno", $R V E H$, núm.6, 2003, pp. 51-77.

- "El fracaso del derecho concursal ya declarado", en Anuario de derecho concursal, núm. 30, 2013, pp. 160 y ss.

- "La prueba de la regla de la discrecionalidad empresarial (<<business judment rules $>>$ )", en AA.VV., Estudios sobre órganos de las sociedades de capital, (Coord. JUSTE MENCÍA Y ESPÍN GUTIÉRREZ), v. I, Ed. Aranzadi, Cizur Menor, 2017, pp. 1051-1071.

RECAMAN GRAÑA, E., "Los deberes y la responsabilidad de los administradores”, $R d S$, núm. 45, 2016, pp. 156-161.

- "Algunas reflexiones en torno al inicio del cómputo del plazo de la prescripción de la acción de responsabilidad de los administradores por obligaciones sociales", en AA.VV., Estudios sobre órganos de las sociedades de capital, (Coord. JUSTE MENCÍA Y ESPÍN GUTIÉRREZ), v. I, Ed. Aranzadi, Cizur Menor, 2017, pp. 1258-1270.

REGLERO CAMPOS, L. F., Tratado de Responsabilidad Civil, Ed. Aranzadi, Cizur Menor, 2002.

RIBAS FERRER. V., El deber de lealtad del administrador de sociedades, Ed. La Ley, Madrid, 2010.

RIBELLES ARELLANO, J. M. Y GIMÉNEZ RAMÓN. R., "El administrador de hecho", en Órganos de la sociedad de capital, Ed. Tirant lo Blanch, Valencia, 2008, pp. 657-659.

RIVES-LANGE, J. L., "La notion de dirigeant de fait au sens de laarticle 99 de la loi du 13 juillet 1967 sur le reglament judiciare et la liquidation des biens", en Rec. Dalloz, 1975, pp. 44.

RODRÍGUEZ ARTIGAS, F., "Notas sobre el régimen jurídico del director general de la SA" en AA.VV., Estudios jurídicos en homenaje a Joaquín Garrigues, vol. III, Madrid, 1971, pp. 19 y ss.

- "El deber de diligencia", en AA.VV., El gobierno de las sociedades cotizadas, (Coord. ESTEBAN VELASCO), Ed. Marcial Pons, Madrid, 1999, pp. 419-444.

- "La delegación de facultades del consejo de administración de la sociedad anónima", $R d S$, núm.1, 1993, pp. 91 y ss.

- "Algunas cuestiones sobre la responsabilidad de los Administradores de Sociedades Anónimas por no promoción de la disolución en caso de pérdidas (art. 262.5 LSA). STS de 16 de diciembre de 2004”, $R d S$, núm. 24, 2005, pp. 295 y ss.

- “Comentarios a las recomendaciones del Código Unificado de Buen Gobierno", RdS, 2007. 
- “Empresario Individual y representación”, en AA.VV., Hacía un nuevo Código Mercantil, Hacia un nuevo Código Mercantil (Coord. BERCOVITZ RODRÍGUEZ-CANO), Ed. Thomson Reuters, Aranzadi, Cizur Menor, 2014, pp. 86-88.

RODRÍGUEZ DE LAS HERAS BALLELL, T., "Las nuevas normas norteamericanas sobre de las sociedades cotizadas. Sarbarnes-Oxley Act”, DN, núm. 138, 2002, pp. 1-16.

- "Requisitos para ser administrador y la extensión subjetiva de la responsabilidad. El régimen contenido en los artículos 212, 236, y 237 de la ley de Sociedades de Capital tras la reforma de la ley de mejora del Gobierno Corporativo", en AA.VV., Gobierno corporativo: la estructura del órgano de gobierno y la responsabilidad de los administradores" (Dir. MARTÍNEZ-ECHEVARRÍA Y GARCÍA DUEÑAS), Ed. Thomson Reuters Aranzadi, Cizur Menor, 2015. pp. 763-761.

RODRIGUEZ DÍAZ, I., "El representante administrador persona jurídica”, RDBB, núm. 128, 2012, pp. 35- 67.

- "La responsabilidad del representante del administrador persona jurídica en el concurso culpable", $A D C$, núm. 308, 2013, pp. 139 y ss.

- "El administrador oculto", RDBB, núm. 138, 2015, pp. 7-47.

RODRÍGUEZ RUÍZ VILLA D. Y HUERTAS VIESCA, M. I., Responsabilidad de los administradores de las sociedades de capital. Prólogo de VICENT CHULIÁ. Ed. Aranzadi, Navarra, 2012.

RODRÍGUEZ RUÍZ VILLA, D., "Límites legales a la actuación de los administradores de la sociedad opada (Art. 60 bis LMV) y desarrollo reglamentario", $R d S$, núm. 35, 2016, p. 12.

RODRÍGUEZ SÁNCHEZ., S., "Responsabilidad del administrador de hecho, algunos supuestos controvertidos", en AA.VV., Estudios sobre la responsabilidad de los administradores de las sociedades de capital a la luz de sus recientes reformas legislativas y pronunciamientos judiciales" (Coord. DÍAZ MORENO Y VÁZQUEZ CUETO), Ed. Aranzadi, Cizur Menor 2018, pp. 125-158.

- "Naturaleza y caracteres de la responsabilidad concursal de los administradores de sociedades de capital (a propósito de la sentencia de la Sección 15ª de la Audiencia provincial de Barcelona de 19 de marzo de 2007)", RDCP, núm. 7, 2007, pp. 151 y ss.

- Protección de la discrecionalidad empresarial y cumplimiento del deber de diligencia”, en AA.VV., Junta general y Consejo de administración en la sociedad cotizada (Coord. RONCERO SÁNCHEZ), t. II, Ed. Aranzadi, Cizur Menor, 2015, pp. 386-423.

ROJO FERNÁNDEZ-RÍO, A., “Los grupos de sociedades”, RDM, núm. 220, 1996. 
- "Los deberes legales de los administradores en orden a la disolución de las sociedades de capital como consecuencia de pérdidas", Derecho de Sociedades, Libro homenaje a Fernando Sánchez Calero, v. II, Ed. McGraw Hill, Madrid, 2002, pp. 1437 y ss.

- "La reforma del derecho concursal español", en AA.VV., La reforma de la legislación concursal (Dir. ROJO), Ed. Marcial Pons, Madrid, 2003, pp. 87-149.

RONCERO SÁNCHEZ, A., "Protección de la discrecionalidad empresarial y cumplimiento del deber de diligencia", en AA.VV., Junta General y Consejo de Administración en la sociedad cotizada (Coord. RONCERO SÁNCHEZ), T. II., Ed. Aranzadi, Cizur Menor 2015.

RUANO BORRELLA, J. P., "Registro mercantil", en AA.VV., Hacía un nuevo código mercantil (Coord. BERCOVITZ RODRÍGUEZ-CANO), Ed. Thomson Reuters Aranzadi, Cizur Menor, 2014, pp. $115-122$.

RUBIO GARCÍA-MINA, J., Sainz de Andino y la codificación mercantil, Consejo Superior de Investigaciones Científicas, Madrid, 1959.

RUBIO SANZ, J., Curso de derecho de sociedades anónimas, Ed. 3ª, Madrid, 1974.

SACCO, R., "Il contrato", en Tratatto de diritto civile, pp. 124 y ss.

SACRISTÁN BERGIA, F., "La conclusión del concurso por insuficiencia de masa, y sus efectos sobre los administradores societarios", en AA.VV. Estudios sobre órganos de las sociedades de capital (Coord. JUSTE MENCÍA Y ESPÍN GUTIÉRREZ), v. II, Ed. Aranzadi, Cizur Menor, 2017, pp. 835855.

SÁENZ GARCÍA DE ALBIZU, J. C., El objeto social en la sociedad anónima, Ed. Cívitas, Madrid, 1990.

SAÍNZ MORENO, F., Conceptos jurídicos, interpretación y discrecionalidad empresarial, Ed. Cívitas, Madrid, 1979.

SALDAÑA VILLOLDO, B., "Acciones de responsabilidad: artículos 239 a 241 bis", en AA.VV., Régimen de deberes, y responsabilidad de los administradores en las sociedades de capital (Coord. HERNANDO CEBRIÁ), Ed. Bosch, Barcelona, 2015, pp. 363-420.

SALELLES CLIMENT, J. R., El funcionamiento del consejo de administración, Ed. Vitas, Madrid. 1995.

SÁNCHEZ ÁlVAREZ, M., "Grupos de Sociedades y responsabilidad de los administradores”, en RDM, núm. 227, 1998, pp. 122 y ss.

- "El Código Olivencia y la responsabilidad de los miembros del Consejo de Administración", $R d S$, núm. 11, 1998, pp. 133-154. 
- "Fundamento del régimen jurídico de los grupos de sociedades", en AA.VV., Estudios sobre órganos de las sociedades de capital, Estudios sobre órganos de las sociedades de capital (Coord. JUSTE MENCÍA Y ESPÍN GUTIÉRREZ), v. II, Ed. Aranzadi, Cizur Menor, 2017., pp. 856-898.

SÁNCHEZ CALERO, F., "Supuestos de responsabilidad de los administradores en la sociedad anónima", en Derecho mercantil de la Comunidad Económica Europea, Estudio en Homenaje a J. Girón Tena, Madrid, 1991, p. 920.

- "Administradores", en AA.VV., Comentarios a la Ley de Sociedades Anónimas, T. IV- II, Ed. Revista de Derecho Privado, Madrid, 1994, pp. 158 y ss.

- "De nuevo sobre la regulación de los grupos de sociedades", $R D B B$, núm.77, 2000, p. 7 y ss.

- La sociedad cotizada en bolsa en la evolución del derecho de sociedades, Ed. Real Academia de la Jurisprudencia y Legislación, Madrid, 2001.

- "Observaciones preliminares al proyecto de Ley de modificación del régimen de las sociedades cotizadas y de las anónimas en general, tras el Informe Aldama”, RdS, núm. 20, 2003.

- "Algunas cuestiones concursales relativas a los Grupos de Sociedades", $A D C$, núm. 5, 2005, pp. 24 y ss.

- Los administradores en las sociedades de capital, Ed. Aranzadi, Cizur Menor, 2007.

- Instituciones de Derecho Mercantil, vol. I, Ed. Aranzadi, Pamplona 2009.

SÁNCHEZ-CALERO GUILARTE, J., "Las políticas en materia de control/ supervisión de riesgos, información financiera y sistemas internos de control de riesgos e información. La comisión de auditoría y sus relaciones al respecto con el consejo de administración (art. 529 Ter $1^{\circ}$. b) y d) en relación con el art. 529 quarterdecies LSC", en AA.VV., Junta General y Consejo de administración en la sociedad cotizada (Coord. RONCERO SÁNCHEZ), t. I, Ed. Aranzadi, Cizur Menor, 2015, pp. 227-272.

"Administrador hecho hay quebarlo", http://jsanchezcalero.blogspot.com.es/2014/06/administrador-de-hecho-hay-que-probarlo.html, 6 de junio de 2014, pp. 1-3.

- Creación de valor, interés social y responsabilidad social corporativa, http//www.vam es/espiritus, p. 17.

SÁNCHEZ-CALERO GUILARTE, F. Y PULGAR EZQUERRA, J., Presupuestos objetivos de la quiebra en derecho español, Universidad de Almería, 2000, p. 373.

SÁNCHEZ RUÍZ, M., "Conflicto de intereses entre socios en sociedades de capital”, $R d S$, Navarra, 2000, pp. 184 y ss. 
SANCHO GARGALLO, I., "La responsabilidad de los administradores pro las deudas de la sociedad derivada del incumplimiento de los deberes legales de promover la disolución (artículos 262 LSA y 105 LSRL)”, en AA.VV., Órganos de la sociedad de capital (Dir. GIMENO-BAYÓN COBOS Y GARRIDO ESPA), Ed. Tirant lo Blanch, Valencia, 2008, pp. 1151-1180.

- "La extensión subjetiva del régimen de responsabilidad de los administradores de hecho y ocultos a la persona jurídica representante del administrador persona jurídica (art. 236.3 y 5 LSC)", en AA. VV., Junta General y Consejo de administración en la sociedad cotizada (Coord. RONCERO SÁNCHEZ), Ed. Aranzadi, Cizur Menor, 2015, pp. 613-632.

SANJUAN Y MUÑOZ, E., "Competencia de la Junta de sociedades en los asuntos de gestión (competencias generales y adicionales", en AA.VV., Derecho de sociedades. Revisando el derecho de sociedades de capital (Coord. GONZÁLEZ FERNÁNDEZ Y GALACHO ABOLAFIO), Ed. Tirant Lo Blanch, Valencia, 2018, pp. 778-824.

SANTOS BRIZ, J., "La responsabilidad civil, fiscal y penal de directivos, apoderados, administradores de hecho, liquidadores", en AA.VV., La responsabilidad de los administradores de las sociedades de capital. Ed. Estudios de Derecho Judicial (CGPJ y Consejo General del Notariado), Madrid, 2000, pp. 329-353.

SANTOS RODRÍGUEZ, P. Y RUS RUFINO, S., "Evolución filosófico-jurídica de la estructura social y económica de las corporaciones mercantiles y de la empresa", en AA.VV., Gobierno corporativo: la estructura del órgano de gobierno y la responsabilidad de los administradores (Dir. MARTÍNEZECHEVARRÍA Y GARCÍA DUEÑAS), Ed. Thomson Reuters Aranzadi, Cizur Menor, 2015, pp. 1592.

SANZ GARCÍA DE ALBIZU, J. C., El objeto social en la sociedad anónima, Ed. Cívitas, Madrid, 1990, pp. 348-349.

SANZ PARAISO, L., F., "Las comisiones de auditoría y cumplimiento", en AA.VV., Gobierno corporativo: la estructura del órgano de gobierno y la responsabilidad de los administradores (Dir. MARTÍNEZ-ECHEVARRÍA Y GARCÍA DUEÑAS), Ed. Thomson Reuters Aranzadi, Cizur Menor, 2015, pp. 373-414.

SENET MARTÍNEZ, S., "Real Decreto- Ley 1 /2015, de 27 de febrero, de mecanismo de segunda oportunidad, reducción de carga financiera y otras medidas de orden social", Fascículo de actualización de la Ley Concursal (Coord. MACÍAS CASTILLO Y JUEGA CUESTA), Ed. Lefévre, El Derecho, Madrid, 2015.

SERRANO CAÑAS, J. M., El conflicto de intereses en la administración de sociedades mercantiles, Publicaciones del Real Colegio de España, Bolonia, 2008. 
SIERRA HERRERO, A., Administradores de las sociedades mercantiles, Ed. Aranzadi, Cizur Menor, 2008 .

SIGNES DE MESA, J. I., "La sección 404 de la Sabanes-Oxley Act y los controles internos financieros: un balance tras de años de aplicación”, $R D B B$, núm. 28, octubre-diciembre, 2012, pp. 161-182.

SPALDING, W.R.Y LECLERC, R. J. Y HOPKINS, J. D., "General Counsel- Delaware Fiduciary Duties-Intersection of Developing Trends", en http://www.bna.com delawere-fiduciary-duties; http://www.bna.com/delawere-fiduciary-duties, 2014.

TAPIA HERMIDA, A., "La alta dirección empresarial, (altos cargos)", en AA.VV., Estudios de derecho mercantil en homenaje al Profesor Broseta Pons, vol. III, Valencia, 1995, pp. 3728 y ss.

- "Problemática conceptual del grupo de sociedades mercantiles", en AA.VV., Estudios sobre órganos de las sociedades de capital, (Coord. JUSTE MENCÍA Y ESPÍN GUTIÉRREZ), v. II, Ed. Aranzadi, Cizur Menor, 2017, pp. 917-939.

TUA PEREA, J., "El marco conceptual y su utilización en la NIC", en AA.VV., Las NIC. Análisis y Aplicación (Coord. CAÑIBANO CALVO), Navarra, 2006, p. 40.

UNCETA LABORDA, M., "La configuración del órgano de administración: el sistema monista y el sistema dual. Especial referencia al régimen de la sociedad anónima europea" en AA.VV., Gobierno corporativo, la estructura del órgano de gobierno y la responsabilidad de los administradores (Dir. MARTÍNEZ-ECHEVARRÍA Y GARCÍA DUEÑAS), Ed. Thomson Reuters Aranzadi, Cizur Menor, 2015, p. 165-205.

URÍA GONZÁLEZ, R., Derecho Mercantil, Ed. Aguirre, Madrid, 1976.

- Derecho mercantil, Ed. Marcial Pons, Madrid, 2002.

VALENZUELA GARACH., J., La responsabilidad de los administradores en la disolución y el concurso de las sociedades capitalistas, Ed. Marcial Pons, Madrid-Barcelona, 2007.

VALPUESTA GASTAMINZA, E., Comentarios a la Ley de Sociedades de Capital, Ed. Bosch, Barcelona.

- "Equiparación con el administrador de la persona que tenga atribuidas facultades de más alta dirección (art. 236. 4 LSC)", en AA.VV., Junta General y Consejo de administración en la sociedad cotizada (Coord. RONCERO SÁNCHEZ), t. II, Ed. Aranzadi, Cizur Menor, 2015, pp. 663-661.

VÁZQUEZ RUANO, T., "El buen gobierno corporativo de las sociedades cotizadas. Aproximación al régimen de los consejeros independientes", en AA.VV., Estudio sobre la responsabilidad de los administradores de las sociedades de capital a la luz de sus recientes reformas legislativas y 
pronunciamientos judiciales (Dir. DÍAZ MORENO Y VÁZQUEZ CUETO), Ed. Aranzadi, Cizur Menor, 2018, pp. 209-238.

VEBLEN, T., The Engineers and the Price system, New York. New York, 1924.

- The theory of bussiness enterprise, New York, 1990.

VELASCO SAN PEDRO, L. A., "La información en el consejo de administración; derechos y deberes del Consejo de los consejeros", en AA.VV., El gobierno de las sociedades cotizadas (Coord. ESTEBAN VELASCO), Ed. Marcial Pons, Madrid, 1999, pp. 305-369.

- "Las facultades del consejo de administración legalmente indelegables tras la reforma de la Ley 31/2014" en AA.VV., Estudios sobre órganos de las sociedades de capital (Coord. JUSTE MENCÍA Y ESPÍN GUTIÉRREZ), v. II, Ed. Aranzadi, Cizur Menor, 2017, pp. 213-234.

VELOSO CARO, J., "El deber de lealtad de los administradores (artículo 26 de la Ley de sociedades de capital" en AA.VV., Gobierno Corporativo: la estructura del órgano de gobierno y la responsabilidad de los administradores" (Dir. MARTÍNEZ-ECHEVARRÍA Y GARCÍA DUEÑAS), Ed. Thomson Reuters Aranzadi, Cizur Menor, 2015, pp. 425-466.

VERDÚ CAÑETE, M. J., La responsabilidad civil del administrador de sociedades de capital en el concurso de acreedores, Ed. La Ley, Madrid, 2008, pp. 40-41.

VICENT CHULIÁ, F., Compendio Critico, t, I, vol. 2, Ed. Bosch, Barcelona, 1991, pp. 888-907.

- “La responsabilidad de los administradores en el concurso”, $R D C$, núm. 4, 2006, pp. 15 y ss.

- Introducción al Derecho Mercantil, Ed. Tirant lo Blanch, Valencia, 2008.

VIERA GONZÁLEZ, A. J., "Las sociedades de capital cerradas”, RdS núm. 18, 2002, pp. 37-41.

VILLANUEVA GARCÍA-POMAREDA, B., "La responsabilidad concursal de los administradores sociales", CMS, julio, 2012.

VILLAR EZCURRA, M., "La responsabilidad tributaria", en AA.VV., La responsabilidad de los administradores de las sociedades mercantiles (Dir. ROJO FERNÁNDEZ-RÍO Y BELTRÁN SÁNCHEZ), Ed. Tirant lo Blanch, Valencia, 2005, pp. 468-512.

VIÑUELAS SANZ, M., "La modificación del ámbito objetivo de la responsabilidad de los administradores por las deudas sociales”, RDM, núm. 266, 2007, pp. 995-1036. 
